\title{
TOWARDS A CHRISTIAN LITERARY THEORY
}

\author{
Luke Ferretter
}
A Thesis Submitted for the Degree of PhD at the
University of St Andrews

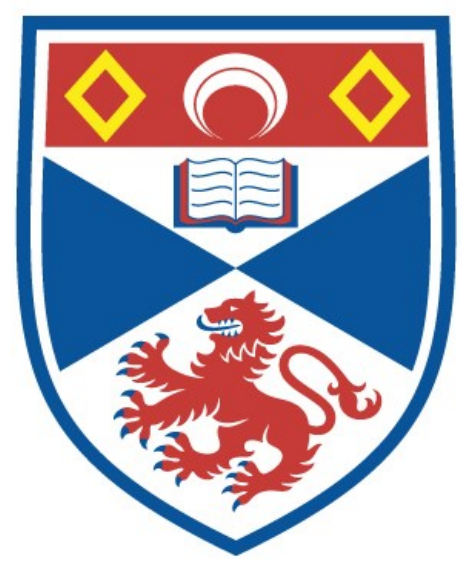

1999

Full metadata for this item is available in

St Andrews Research Repository

at:

$\underline{\text { http://research-repository.st-andrews.ac.uk/ }}$

Please use this identifier to cite or link to this item:

http://hdl.handle.net/10023/15232

This item is protected by original copyright 


\title{
Towards a Christian Literary Theory
}

\author{
Luke Ferretter
}

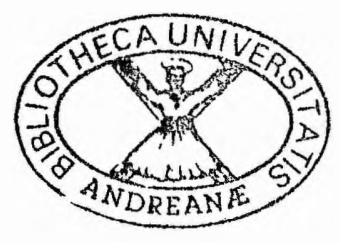

Submitted to the University of St. Andrews for the degree of Ph.D., $23^{\text {rd }}$ September 1998 
All rights reserved

INFORMATION TO ALL USERS

The quality of this reproduction is dependent upon the quality of the copy submitted.

In the unlikely event that the author did not send a complete manuscript and there are missing pages, these will be noted. Also, if material had to be removed, a note will indicate the deletion.

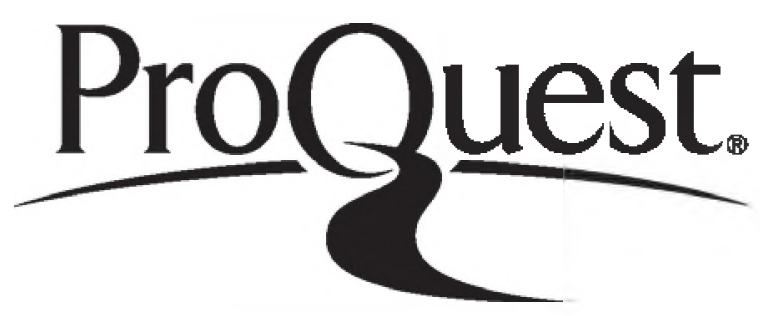

ProQuest 10170873

Published by ProQuest LLC (2017). Copyright of the Dissertation is held by the Author.

All rights reserved.

This work is protected against unauthorized copying under Title 17, United States Code Microform Edition (c) ProQuest LLC.

ProQuest LLC.

789 East Eisenhower Parkway

P.O. Box 1346

Ann Arbor, Ml 48106 - 1346 
An $D^{24}$ 


\begin{abstract}
Most contemporary literary theories are either explicitly or implicitly atheistic. This thesis describes a literary theory whose principles are derived from or consistent with Christian theology. It argues against modern objections to such a theory that this is a rationally and ethically legitimate mode of contemporary literary theory.

The first half of the thesis constitutes an analysis of deconstruction, of Marxism and of psychoanalysis. These are three of the most influential discourses in modern literary theory, each of which constitutes a significant argument against the existence of God, as this has traditionally been understood in Christian theology. In a chapter devoted to each theory, I examine its relation to Christian theology, and argue that it does not constitute a conclusive argument against the truth-content of such theology. I go on to assess which of its principles can be used in modern Christian literary theory, and which cannot.

The second half of the thesis constitutes an analysis of a Christian tradition of thought that pertains to literary theory. In the fourth chapter, I examine the concepts of language and of art expressed or implied in the Bible, St. Augustine and St. Thomas Aquinas, and assess which of these concepts could be used in Christian literary theory today. In the fifth chapter, I examine certain twentieth-century Christian philosophers and literary critics, and assess how their thought could be used in contemporary Christian literary theory.
\end{abstract}


In the final chapter, I synthesize the conclusions to these arguments into the outline of a literary theory that both derives from Christian theology and takes account of the objections to such theology posed by contemporary literary theories. 


\section{Declarations}

(i) I, Luke Ferretter, hereby certify that this thesis, which is approximately 100,000 words in length, has been written by me, that it is the record of work carried out by me and that it has not been submitted in any previous application for a higher degree.

Date. $23 / 9 / 98$ Signature of candidate

(ii) I was admitted as a research student in October 1994 and as a candidate for the degree of Ph.D. in October 1994; the higher study for which this is a record was carried out in the University of St. Andrews between 1994 and 1998.

Date. $23.9 / 98$ Signature of candidate

(iii) I hereby certify that the candidate has fulfilled the conditions of the Resolution and Regulations appropriate for the degree of Ph.D. in the University of St. Andrews and that the candidate is qualified to submit this thesis in application for that degree.

Date 2.4 .98 . Signature of supervisor.

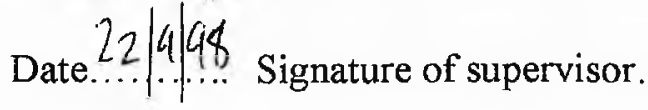


In submitting this thesis to the University of St. Andrews, I understand that I am giving permission for it to be made available for use in accordance with the regulations of the University Library for the time being in force, subject to any copyright vested in the work not being affected thereby. I also understand that the title and abstract will be published, and that a copy of the work may be made and supplied to any bona fide library or research worker.

Date. $23 / 9 / 98$ Signature of candidate 


\section{Acknowledgements}

I would like to thank my supervisors, Dr. Ian Johnson, the late Mr. Stephen Boyd, and Mr. Anthony Ashe, for their help in reading and commenting on the several versions of this work.

I would like to thank those members of the English department at St. Andrews who gave generously of their time and expertise, especially Prof. Susan Sellers, Prof. Robert Crawford, Prof. Michael Alexander and Prof. Nicholas Roe. Prof. Douglas Dunn chaired a department in which every aspect of writing a doctoral thesis was facilitated. Dr. James Alexander of St. Mary's College, and Dr. Anthony Meredith, S.J., of Heythrop College, gave valuable suggestions on St. Augustine. Prof. David Jasper of Glasgow University helped with biographical details.

I would like to thank my parents for their support throughout the years in which this thesis was conceived and written. Most of all I would like to thank my wife Jen, to whom this thesis is dedicated, for her constant love and belief in me. 


\section{Contents}

Introduction 1

1. On Deconstruction 8

(i) An Outline of Deconstructive Criticism 8

1. Derrida's Reading of Husserl 9

2. Deconstruction 19

3. Derrida's Reading of Literary Texts 22

4. Deconstructive Literary Criticism . 27

(ii) Deconstruction and Christianity 31

1. Derrida and the Concept of Theology 31

2. Derrida and Negative Theology 41

(iii) A Critique of Deconstruction 51

1. The Marxist Critique 53

2. The Hermeneutic Critique 59

2. On Marxism 63

(i) An Outline of Marxist Literary Theories 63

1. Karl Marx 64

2. Louis Althusser 69

3. Pierre Macherey 74

$\begin{array}{ll}\text { 4. Terry Eagleton } & 78\end{array}$

5. Fredric Jameson 83

(ii) Marxism and Christianity $\quad 88$ 
1. Marx, Engels and Lenin on Religion 89

2. An Assessment of Marxist Atheism 93

3. Liberation Theology 96

4. Catholic Social Thought 102

(iii) A Critique of Marxist Literary Theories 112

1. The Concept of Ideology 112

$\begin{array}{ll}\text { 2. Intra-Marxist Critique } & 119\end{array}$

$\begin{array}{ll}\text { 3. On Psychoanalysis } & 125\end{array}$

(i) An Outline of Psychoanalytic Literary Theories 125

$\begin{array}{ll}\text { 1. Sigmund Freud } & 126\end{array}$

$\begin{array}{ll}\text { 2. Freudian Literary Criticism } & 137\end{array}$

3. Jacques Lacan 139

4. Lacanian Literary Criticism 145

5. Julia Kristeva 148

(ii) Psychoanalysis and Christianity 155

1. Freud on Religion 155

2. An Assessment of Freud's Atheism 160

3. Jung and Fromm on Religion 166

4. Psychoanalysis and Christian Tradition 173

(iii) A Critique of Psychoanalytic Literary Theories $\quad 180$

1. The Empirical Critique 180

2. The Feminist Critique 188 
4. Christian Tradition and Literary Theory 197

(i) The Bible 197

1. The Logos 198

2. Adam's Names 203

3. The Tower of Babel 204

$\begin{array}{ll}\text { 4. Pentecost } 208 & \end{array}$

5. Art in the Bible 211

$\begin{array}{ll}\text { (ii) St. Augustine } & 216\end{array}$

1. St. Augustine's Theory of Signs 217

2. St. Augustine's Theory of Beauty 227

3. St. Augustine's Theory of Art 233

(iii) St. Thomas Aquinas $\quad 239$

1. Theological Language 240

2. St. Thomas' Theory of Beauty 246

3. St. Thomas' Theory of Art 251

5. Modern Christian Literary Theories 263

$\begin{array}{ll}\text { (i) Hermeneutics } & 263\end{array}$

1. Gadamer's Theory of Authority and Tradition 264

2. The Gadamer-Habermas Debate 268

3. Gadamer's Poetics 275

(ii) Neo-Thomism 280

1. Jacques Maritain 281 
2. Eric Gill 295

3. David Jones 298

(iii) Religion and Literature $\quad 302$

1. T.S. Eliot and the New Criticism 302

2. Nathan Scott and Existential Theology 308

3. Contemporary Christian Theories 313

6. Conclusion 326

$\begin{array}{ll}\text { Bibliography } & 337\end{array}$ 


\section{Introduction}

Most contemporary literary theories are atheistic. In 'The Death of the Author' (1968), Roland Barthes describes the emphasis on textuality characteristic of post-structuralism as 'an anti-theological activity..., since to refuse to fix meaning is, in the end, to refuse God and his hypostases - reason, science, law'. The philosophers to whom modern literary theory is most indebted - Marx, Nietzsche and Freud - have argued that the truth-content of religious beliefs is negated by their social and psychological determinants. Post-structuralist theories emphasise that the language in which such beliefs are expressed cannot support the truth-claim that they imply. It seems that contemporary literary study is incompatible as such with Christian faith. This thesis argues that this is not the case.

In his book Justifying Language (1995), Kevin Mills writes that his goal is to affirm the viability of a critical belief which is cognisant of the array of philosophico-linguistic objections to its existence, and yet understands why faith, hope and love are able to remain in the face of this onslaught. ${ }^{2}$

One of the reasons why Mills can assert that it is possible consistently to hold a Christian faith after understanding the modern objections to it is that there is no system of thought that does not at some point involve an act of faith. In Does God Exist? An Answer for Todory (1978), the Catholic theologian Hans Küng argues this point in his study of Nietzschean nihilism. He asserts that each of us makes a 'fundamental decision' about reality as a whole, a choice of what self, others and the world mean to us, which grounds all our subsequent actions and

\footnotetext{
1 Roland Barthes. Image Music Text, tr. Stephen Heath (London: Fontana 1977) p. 147.

2 Kevin Mills, Justifying Language: Paul and Contemporary Literary Theory (London. Macmillan. 1995) p. 2.
} 
convictions. Nietzsche has made clear that reality is not self-evident, Küng argues, and so this decision is ultimately a matter of trust. He writes:

The fundamental alternative is a (considered or unconsidered) Yes or No to reality in principle: an unforcable and unprovable trust or mistrust in the reality of the world and of my own self. ${ }^{3}$

In the end, I either believe that reality has identity, meaning and value or I do not. Küng argues that the former choice, which he calls 'fundamental trust' in reality, is the basis both of science and of ethics. Citing philosophers of science from Karl Popper to Thomas Kuhn, Küng argues that 'all rational thinking rests on a choice, a resolution, a decision, an attitude; in a word, on a "faith in reason" ${ }^{2}{ }^{4}$ A rationalism which attempts to base every proposition on arguments or experience cannot itself be based on arguments or experience, but must be believed to be a valid way of understanding reality. Küng adds that a similar act of faith is the precondition of ethics:

Any acceptance of meaning, truth and rationality, of values and ideals, priorities and preferences, models and norms, presupposes a fundamental trust in uncertain reality.

Every positive system of thought at some point involves an act of faith, a decision simply to commit oneself to something that cannot be proved. Even nihilism is based on such a decision. If this is true, then Christian theology and modern literary theory are not incommensurate discourses. It is not the case that whereas the latter is based on critical reason and ethics, the former derives from an irrational faith that results in unethical values. On the contrary, Christians share with modern literary theorists an understanding of reality whose most

\footnotetext{
${ }^{3}$ Hans Küng, Does God Exist? An Answer For Today, tr. Edward Quinn (London: Collins, 1980) p. 439.

Ibid. p. 461.

${ }^{5}$ Ibid. p. 470 .
} 
fundamental axioms are neither proved nor provable, but in the end simply believed.

Granted that literary theory and Christian faith are not in principle incompatible, it may be asked whether it is meaningful or valuable in practice to associate them. It may be objected that criticism should be practised according to strictly critical norms, and Christian faith should be reserved for theology and ethics, to which it properly pertains. This objection ignores the most fundamental insight of modern literary theory, however, that there is no critical discourse that does not derive from some theory or theories, however unconscious or illassorted. As Catherine Belsey writes, in Critical Practice (1980):

There is no practice without theory, however much that theory is suppressed, unformulated or perceived as 'obvious'. [Reading] presupposes a whole theoretical discourse...about the relationships between meaning and the world, meaning and people, and finally about people themselves and their place in the world. ${ }^{6}$

Whether I write about what John Donne's imagery tells me about his particular way of perceiving of the world, or about the political significance of his representations of women, I cannot but derive my interpretations and judgements from a more or less conscious system of opinions about the way the world is and about what should be done in it. Since Christian theology constitutes the basis of such a world-view, it is reasonable to imagine a critical discourse whose interpretations and judgements derive from it or from principles consistent with it. My aim in this thesis is to describe such a discourse.

I will begin with some working definitions. In The Nature of Doctrine (1984), George Lindbeck argues that Christian doctrines are

\footnotetext{
${ }^{6}$ Catherine Belsey, Critical Practice (London and New York: Routledge, 1980) p. 4. In After Virtue: A Study in Moral Theory, Alisdair MacIntyre makes a similar point about facts: 'What each observer takes himself or herself to perceive is identified and has to be identified by theoryladen concepts' (Notre Dame: University of Notre Dame Press, 1981 p. 79).
} 
communally authoritative teachings regarding beliefs and practices that are considered essential to the identity or welfare of the group in question. $^{7}$

This statement makes clear that any definition of Christian doctrine is determined by the community in which it is formulated. My definition is no exception, and is determined by the Roman Catholic community within which I write. I will mean by 'Christian' doctrines those Catholic doctrines from which the major Protestant confessions and the Eastern Orthodox communions do not dissent. There is no brief summary of Catholic doctrines, like the Church of England's Thirty-Nine Articles or the Presbyterian Westminster Confession. Even lengthy volumes like Denzinger's Enchiridion Symbolorum and the Catechism of the Catholic Church do not represent the complete doctrinal content of the Catholic faith. This is partly because, as Vatican II asserts, the primary object of revelation is 'God...Himself', in Christ, whose meaning cannot be exhausted in dogmatic propositions. ${ }^{8}$ Furthermore, as Catholic theologian Karl Rahner argues in 'The Development of Dogma' (1954), the development of these propositions is a necessity of the church's historical existence:

The real understanding of what is revealed and its existential appropriation by men is wholly dependent on the transformations of the propositions of faith, as they were originally heard, into propositions which relate what is heard to the historical situation of the men who hear. ${ }^{9}$

In Foundations of Christian Faith (1976), Rahner argues that Scripture, as 'the objectification of the original church's consciousness of the faith', is the norm of Catholic doctrine. The church's teaching office, he writes, has the task of

\footnotetext{
${ }^{7}$ George Lindbeck, The Nature of Doctrine: Religion and Theology in a Postliberal Age (Philadelphia: The Westminster Press, 1984) p. 74

${ }^{8}$ Dei Verbum no. 2, in Walter M. Abbott and Joseph Gallagher, tr. and ed., The Doctments of Vatican II (New York: Association Press, 1966) p. 112.
} 
'always interpreting it anew in historically changing horizons of understanding as the one truth which always remains the same'. ${ }^{10}$ Vatican II's decree on ecumenism, Unitatis Redintegratio (1964), asserts that in Catholic teaching there exists an order or "hierarchy" of truths, since they vary in their relationship to the foundation of the Christian faith'. ${ }^{11}$ The structure of this hierarchy has not been specified. For the purpose of this thesis, I will take those doctrines that are shared by the major Protestant and Orthodox confessions as its fundamental level, and will refer to them as 'Christian' doctrines.

I will mean by 'literary' texts, fictional texts which are found valuable. In Literary Theory (1983), Terry Eagleton argues that fictionality cannot be used as a criterion for defining literature, pointing out that much prose intended accurately to describe the author's understanding of reality is studied in literature courses. $^{12}$ The logic of his argument that literature is constituted by readers' relations to texts, however, suggests that the same text can be read both as fiction or in a different way. If I read John's Donne's sermons for advice on my spiritual life, or The Cloud of Unknowing to learn how to contemplate, then I am reading them as something like science. If on the other hand I read these texts without expecting them directly to describe some aspect of reality, then I am reading them as fiction, in the sense of that term that denotes a text or part of a text that is not understood as an accurate description of reality. In defining literature as texts read in this way and 'found valuable', I am accepting the modern axiom that, since values are determined by the social and historical context of the

\footnotetext{
${ }^{9}$ Karl Rahner, Theological Investigations Vol. 1: God, Christ, Mary and Grace, tr. Comelius Ernst (London: Darton, Longman and Todd, 1961) p. 47.

${ }^{10}$ Karl Rahner, Foundations of Christian Faith: An Introduction to the Idea of Christianity, tr. William V. Dych (London: Darton, Longman and Todd, 1976) p. 377.

${ }^{11}$ Unitatis Redintegratio no. 11, in Abbott and Gallagher, Vatican II p. 354.

${ }^{12}$ Terry Eagleton, Literary Theory: An Introduction (Oxford: Blackwell, 1983) pp. 1-2.
} 
discourses in which they are formulated, literature is a historically variable category. I take 'literary theory' to denote discourse concerned with texts in general, and in particular with the nature and function of literary texts. By 'Christian literary theory', I will mean a theory of the nature and function of fictional texts found valuable, which is derived from those fundamental doctrines of the Catholic faith shared by the major Protestant and the Orthodox confessions, or from principles consistent with them.

I will use two methods of constructing such a theory in this thesis. In the first three chapters, I will examine what I take to be the fundamental discourses of modern literary theory, deconstruction, Marxism and psychoanalysis. Each of these theories constitutes a significant argument against the existence of God, as this has been traditionally understood in Christian theology. In each chapter, I will examine the relations between the modern theory and Christian theology, and describe the significance of this relation for Christian literary theory. I will assess what I take to be the value of each discourse, and suggest which of its insights could be used in Christian literary theory and how. I will also offer a critique of each theory, to suggest that it should not be taken as authoritative or as a modern orthodoxy. In this first half of the thesis, I aim to show that the concept of Christian literary theory is a legitimate one, and to have begun to elaborate some of the principles in which it might consist. In the next two chapters, I will expound these principles in greater detail. In the fourth chapter, I will examine some of the fundamental texts of Christian tradition, namely those of the Bible, St. Augustine and St. Thomas Aquinas, in order to establish what they contribute to what we now call literary theory. In the fifth chapter, I will examine those twentieth-century literary theories that either explicitly derive 
from or are consistent with Christian theology, and will assess the value of these texts for contemporary theory. In this second half of the thesis, I aim to show both that a Christian tradition of thought pertaining to literary theory exists, and to suggest how it might be used today. 


\section{On Deconstruction}

I will begin with an examination of deconstruction, and of the literary theory and criticism that can or has been called deconstructive. I will have two concerns in this chapter. Firstly, I will examine the effect of deconstruction on Christian theology and vice versa. I shall be particularly concerned with the concept of theology in Derrida's thought, and with the relation between deconstruction and negative theology. Secondly, I will offer a critique of deconstruction, in order to show that, whilst there are certain principles which a Christian literary theory could learn from it, Derrida's work should not be taken as a final authority in literary theory. I will begin this analysis with an introduction to this work and to the deconstructive literary criticism that derives from it.

\section{(i) An Outline of Deconstructive Criticism}

Jacques Derrida (b. 1930) came to develop the practice which has become known as deconstruction as a result of his study of the phenomenology of Edmund Husserl (1859-1938). Based at the Ecole Normale Supérieure in Paris, he also spent time at Louvain and Harvard during the 1950s, and translated Husserl's The Origin of Geometry (1936) with a long introduction in 1962, for which he won the Jean Cavaillès prize. 'After two further articles, Derrida finalised his reading of Husserl in his first monograph, Speech and Phenomena

\footnotetext{
' See Geoffrey Bennington and Jacques Derrida, Jacques Derrida, tr. Geoffrey Bennington (Chicago and London: University of Chicago Press, 1993) pp. 325-336 for biographical information.
} 
(1967), in which he undertook a reading of the first of Husserl's Logical Investigations (1900-1).

\section{Derrida's Reading of Husserl}

Derrida reads Husserl in terms of his relation to metaphysics. It is difficult to give a single definition of this term, since it has been taken to mean many different things, but it generally denotes the branch of philosophy concerned with being. ${ }^{3}$ Metaphysics is a fundamental inquiry whose object is what there is in the world and the nature and modes of its being. In Metaphysics (1983), George Schlesinger writes:

Metaphysical statements refer to features of our world that are present in all the worlds which have so far seemed sufficiently similar to ours for the question of their existence to have arisen...Metaphysicians may therefore be said to be dealing with the essential features of the universe. ${ }^{4}$

The essence of metaphysics for Derrida is what he calls presence. He uses this term in several senses. Firstly it indicates 'the absolute proximity of selfidentity', that is, a subject's guarantee of identity by as it were coinciding with himself, being in the same place and at the same time as himself. ${ }^{5}$ Secondly it indicates 'the being-in-front of the object', that is, the immediate relation a subject has with his perception of an object. ${ }^{6}$ Thirdly it indicates 'the maintenance of the temporal present', that is the non-durational point in time at

\footnotetext{
${ }^{2}$ See "“Genesis and Structure" and Phenomenology" (1959), in Writing and Difference, tr. Alan Bass (London: Routledge, 1978) pp. 154-168, and 'La phénoménologie et la clôture de la métaphysique', published in Greek in Epochês 7 (1966) pp. 181-200.

${ }^{3}$ See George N. Schlesinger, Metaphysics: Methods and Problems (Oxford: Blackwell, 1983) pp. $9-13$.

${ }^{4}$ Tbid. p. 23.

${ }^{5}$ Jacques Derrida, Speech and Phenomena and other Essays on Husserl's Theory of Signs, tr. David B. Allison (Evanston: Northwestern University Press, 1973) p. 99.
} 
which a subject is conscious of or, in Husserl's terms, 'intends' an object. ${ }^{7}$ These terms sound complex because they are so fundamental to common sense that it is initially difficult to conceive of alternatives to them. Essentially Derrida uses the term 'presence' to mean that the concept which I am currently thinking is present to me, and that I am thinking it now, in the present. This comprises what Husserl calls the 'living' present, in which one is absolutely present to oneself in an absolutely ideal or transcendental 'life'. A discourse that can be shown to depend on presence thus defined Derrida calls 'metaphysical'.

In Speech and Phenomena, Derrida finds this metaphysics of presence at work in Husserl's theory of signs. In an earlier article, 'La phénoménologie et la clôture de la métaphysique' (1966), he had shown that whilst Husserl was overtly opposed to metaphysical speculation, it was in fact a 'degenerate' version of the latter rather than the discourse itself that he criticised. In fact, Derrida writes, he wished to restore an authentic metaphysics. ${ }^{9}$ Metaphysical presuppositions were among those that Husserl wanted to discount or 'bracket' from consciousness in the search for absolutely grounded knowledge which was the motivation of his phenomenology. In Derrida's view, however, the transcendental consciousness in which Husserl locates this knowledge is an appeal to the kind of living present that is the essence of metaphysics. This means that "the phenomenological critique of metaphysics betray[s] itself as a

\footnotetext{
${ }^{6}$ Ibid. The idea of being-in-front is made clearer by the etymology of the German term for object, gegen-stand, something which 'stands opposite' a subject. See also Derrida, Speech and Phenomena p. 9.

${ }^{7}$ Ibid. pp. $99,9$.

${ }^{8}$ Ibid. p. 6 . The term 'ideality' signifies pure mentality, consciousness of a concept that owes nothing to the senses or to materiality in general. 'Transcendence', with reference to Husserl, has a similar meaning, signifying absolute non-worldliness. As Derrida says, the terms occupy the traditional position of soul as opposed to body (Tbid. p. 81).

${ }^{9}$ Ibid. p. 5.
} 
moment within the history of metaphysical assurance'. ${ }^{10}$ For Husserl, 'blindness to the authentic mode of ideality' is the error of degenerate metaphysics. ${ }^{11}$ For Derrida, Husserl's description of this mode is metaphysical: ideality will mean the living present. This is the first of two movements of Derrida's reading of Husserl that will be more or less repeated in future 'deconstructive' readings, the identification of an ultimate appeal to presence as the organising factor of a discourse.

The second movement of the reading is a demonstration that the discourse in question does not rigorously maintain a complete or consistent description of the presence around which it is nevertheless organised. In certain key descriptions of phenomenological consciousness Derrida discerns 'an irreducible nonpresence as having a constituting value'. ${ }^{12}$ We will not go into the details of Husserl's descriptions here; it is sufficient to understand Derrida's point to see that he finds this non-presence in the 're-presentation' (Vergegenwärtigung) by which Husserl describes the mediation of a temporal object to consciousness, and in the 'ap-presentation' (Appräsentation) by which he describes intersubjective relationship. $^{13}$

In Speech and Phenomena, Derrida's point of entry in this double reading of Husserl is the latter's theory of the sign. The Logical Investigations are an early work in the development of Husserl's phenomenology, exhibiting, in Derrida's view, the 'germinal structure' of the whole of the former's thought, in particular of the phenomenological reduction. ${ }^{14}$ The first investigation begins with some

\footnotetext{
${ }^{10}$ Ibid.

"Ibid. p. 6.

${ }^{12}$ Ibid.

${ }^{13}$ Ibid. p. 7

${ }^{14}$ Ibid. p. 3. The phenomenological reduction is a later formulation of Husserl's that, like his distinction of expression from indication, aims at absolutely transcendental self-consciousness.
} 
'essential distinctions' which underwrite the subsequent analyses, the first of which is a distinction between two senses of the word 'sign' (Zeichen), namely 'expression' (Ausdruck) and 'indication' (Anzeichen). The coherence of the chapter, Derrida writes, is founded on this distinction. ${ }^{15}$ In his reading of Husserl, Derrida finds that the theory of the sign elaborated in the first chapter of the first investigation occupies a paradigmatic position with regard to Husserl's relationship to metaphysics.

Husserl privileges expression over indication. In the latter, there is no meaning, in the sense that there is no consciousness intending to communicate something to another. Signification is an accidental property of the indicative sign, examples of which are fossils indicating the existence of prediluvian animals. ${ }^{16}$ Husserl calls these signs 'meaningless'. Expression, on the contrary, is a sign animated by voluntary intention, a 'meaningful sign', as Husserl says. The French term for meaning, vouloir-dire, 'wanting to say', describes the kind of meaning inherent in an expressive sign. ${ }^{17}$ It is, as Derrida shows with careful quotation from Husserl, a live sign, one animated by spirit and will. ${ }^{18}$ He writes, 'Everything that escapes the pure spiritual intention, the pure animation by Geist... is excluded from meaning... and thus from expression'. ${ }^{19}$ Everything physical is excluded from expression as meaning, in order that Husserl can locate meaning in the presence to consciousness of an ideal object. The vehicle of expression therefore is speech, since a speaking subject's meaning is what he

See Ideas: General Introduction to a Pure Phenomenology, where Husserl describes the reduction as 'the necessary operation which renders "pure" consciousness accessible to us' (tr. W.R. Boyce-Gibson, London: Allen and Unwin, 1931, p. 114).

${ }^{15}$ Edmund Husserl, Logical Investigations Vol. I. tr. J.N. Findlay (London: Routledge and Kegan Paul, 1970) pp. 269-298. Derrida, Speech and Phenomena p. 4.

${ }^{16}$ Husserl, Logical Investigations p. 270.

${ }^{17}$ Ibid. p. 275.

${ }^{18}$ See Derrida, Speech and Phenomena p. 35.

${ }^{19}$ Ibid. 
'wants to say'. In speech, one is ex-pressing the interior ideality of an act of consciousness. ${ }^{20}$ Now the difference between indications and expressions, Husserl writes, is functional rather than substantial: the same series of signs can be taken as expressive or as indicative. Indeed speech itself contains a good deal of indication. Insofar as it is engaged in communication or manifestation, Husserl writes, speech operates indicatively, since the animation of the signs by the consciousness of the speaker must pass through a physical vehicle to be received in the consciousness of the hearer. ${ }^{21}$ In short, expression, for Husserl, that is, presence to consciousness of an act of consciousness, occurs only in interior monologue, only when one 'speaks' to oneself in pure ideality, without any detour through the material realm. In 'solitary mental life' one has no need to communicate or indicate anything to oneself and the ideal object of one's meaning is simply present to oneself.

This is the first arm of Derrida's twofold reading of Husserl, his isolation of the function of presence as an organising principle of the latter's thought. The distinction between expression and indication, he shows, depends on an axiological distinction between inside and outside. Meaning, Derrida shows Husserl to have said, is ideal: it occurs in the absolutely mental, or transcendental, realm. Everything outside this realm, all things physical and phenomenal, are assigned to meaninglessness as a result of their mediation and interruption of the presence of an object to consciousness. In a gesture that he will repeat many times, Derrida shows that Husserl's discourse is organised around a distinction between a chain of positive terms based on presence and a chain of negative terms based on difference. On the one hand, there is presence,

\footnotetext{
${ }^{20}$ Ibid. p. 18.

${ }^{21}$ Ibid. p. 38.
} 
ideality, the inside, meaning and life (expression); and on the other hand there is mediation, physicality, the outside, meaninglessness, and death (indication).

The second arm of the reading shows that this governing distinction of the text is not completely or consistently maintained by the text, and that it would be impossible for this to be the case. The principles by which the discourse has been shown to be constructed are in this second movement also de-constructed. The essence of an ideal object, Derrida argues, is that it is repeatable. He writes, 'Independent of the here-and-now acts and events of the empirical subjectivity which intends it, it can be repeated infinitely while remaining the same' ${ }^{22}$ In order to remain the same in these representative repetitions, Derrida argues, an ideal object must be expressed in a medium that does not interrupt the presence of the acts that intend it, that is, a transcendental medium. This medium, Derrida writes, is the voice, 'an element whose phenomenality has no worldly form' ${ }^{23}$ Derrida is referring to the 'phenomenological voice' here, that is, to the heard sound as an object of consciousness (Saussure's 'acoustic image'), as opposed to the 'worldly' or material element of speech. ${ }^{24} \mathrm{He}$ is thinking of the interior monologue to which alone Husserl restricted meaningful utterance. The voice so considered, Derrida writes, is heard and understood at the same time as it is uttered by the subject. (The French verb entendre, which means both to hear and to understand, and so connotes hearing-and-therefore-understanding, helps to convey the point). The intentional acts of solitary mental life, the self-presence of transcendental consciousness, upon which phenomenology is entirely staked, depends for its self-presence on the immediacy of the voice, Derrida argues. The

\footnotetext{
${ }^{22}$ Ibid. p. 75 .

${ }^{23}$ Ibid. p. 76.
} 
meaningfulness (along with all the other terms in that chain, including 'life') of the interior monologue, depends on the fact that I hear myself speak (je $m$ 'entend parler) at the same time that I speak. The living act which animates the signifier into a meaningful expression is in this case not separated from itself. Derrida writes, 'The signifier, animated by my breath and... meaning-intention... is in absolute proximity to me ${ }^{25}$ The voice, he adds, can 'show the ideal object or ideal Bedeutung [Husserl's term for meaning as wanting-to-say] connected to it without venturing outside ideality, outside the interiority of self-present life' ${ }^{26}$ In short, he writes, 'the ideality of the object seems to depend on the voice', and along with it so do all the positive terms Husserl has marshalled on its side of the division between inside and outside. ${ }^{27}$

In Derrida's reading, this transcendence of the voice is 'only apparent '. ${ }^{28}$ S'entendre parler, an absolutely non-worldly self-communication, he writes, 'would in fact be the absolute reduction of space in general' ${ }^{29}$ The absolute proximity of the signifier to the signified is the condition for Husserl's notion of expressive language and of the pre-expressive stratum of meaning that expression expresses. The liveliness or spirituality of the living present, which is what Husserl's project aims to isolate, needs no signifier to be itself. Derrida questions the role of signification at the place in a system where it is not needed. He writes, 'The word is a body that means something only if an actual intention animates it and makes it pass from a state of inert sonority...to that of an animated body... Only the Geistigkeit [spirituality] or Lebendigkeit [alive-ness] is

\footnotetext{
${ }^{24}$ Ibid. Here the reader will also find Derrida's argument against the objection that interiority belongs to the ideal or transcendental aspect of every signifier, and not simply to those that are spoken, as he asserts.

${ }^{25}$ Ibid. p. 77.

${ }^{26}$ Ibid. p. 78.

27 Ibid.
} 
independent and primordial ${ }^{30}{ }^{30}$ Husserl is concerned with the living intention that animates the sign rather than with the animated sign. But this intention, Derrida points out, 'needs no signifier to be present to itself. Indeed it is as much in spite of its signifiers as thanks to them that it is awakened or maintained in life ${ }^{31}$ The mediatory nature of the signifier in fact threatens the self-presence of transcendental life. Derrida writes that the privilege of the voice in transcendental consciousness is an attempt to reduce the difference at work in the essence of the concept of the sign. He suggests that as Husserl assigned difference and mediation (all that interrupts the presence of an ideal object to consciousness) to the exteriority of the signifier, he could not fail to be aware of its operation within the interiority from which he exiled it. The voice is the medium that allows auto-affection, that is, uninterrupted and immediate selfrelationship, but the very concept of auto-affection, Derrida argues, implies difference. $^{32}$ 'Auto-affection supposes that a pure difference comes to divide self-presence', he writes. If I affect myself, however transcendentally, there are two terms involved, the I who affect and the I who am affected. The difference between them will not be reduced, despite Husserl's lengthy and intricate attempts to do so. It is worth quoting Derrida at length here, since we are close to the crux of his ideas:

In this pure difference [between the affecting and the affected self] is rooted the possibility of everything we think we can exclude from autoaffection: space, the outside, the world, the body, etc. As soon as it is admitted that auto-affection is the condition for self-presence, no pure transcendental reduction is possible. ${ }^{33}$

\footnotetext{
${ }^{28}$ Ibid. p. 77.

${ }^{29}$ Ibid. p. 79.

${ }^{30}$ Ibid. p. 81 .

${ }^{31}$ Ibid.

${ }^{32}$ Ibid. p. 82.

${ }^{33}$ Ibid.
} 
Derrida's point is that if, as in Husserl, self-presence is constituted by autoaffection, then what has been conceived as presence is fact constituted by difference. Auto-affection, he writes, is not a mode of being that characterises an entity (the self, autos), as Husserl would like to say, but it 'produces sameness as self-relation within self-difference; it produces sameness as the non-identical' ${ }^{34}$

Derrida's technical-sounding but far-reaching conclusion is that difference is prior to presence and constitutes it, rather than vice versa, as Husserl wants to assert, and as common sense would seem to make obvious. Difference, Derrida concludes, is not a function of two or more presences, but presence is a function of a kind of primordial difference. I have described this conclusion particularly with reference to the 'spatial' sense of presence, the presence of an ideal object to consciousness. In Derrida's reading of Husserl, this is not to be distinguished from the 'temporal' sense of presence, the present moment in which transcendental consciousness occurs. Temporal presence, Derrida argues, is also constituted by a prior difference. The pure meaning of expressive signs in interior monologue, Husserl writes, is mediated not by real words but by representations or imaginations thereof. Derrida shows that the structure of representation (i.e. making present again: the etymology is the same in Husserl's term Ver-gegenwärt-igung) disturbs the instantaneous nature of the present that he also shows is necessary for Husserl to maintain as the time of transcendental subjectivity. ${ }^{35}$ Husserl's later series of lectures on The Phenomenology of Internal Time-Consciousness, Derrida writes, 'demonstrates and confirms throughout the irreducibility of...the re-produced now to the perceived or

\footnotetext{
${ }^{34}$ Ibid.

${ }^{35}$ See Ibid. p. 60: 'Self-presence must be produced in the undivided unity of the temporal present so as to have nothing to reveal to itself by the agency of signs'.
} 
retained actual now'. ${ }^{36}$ In short, 'the presence of the perceived present can appear only inasmuch as it is continuously compounded with a nonpresence', namely that of the remembered or represented past or of the expected future. ${ }^{37}$ Derrida quotes Husserl's assertion that in the last instance, the 'ideal now is not something... different from the not-now, but continually accommodates itself thereto'. ${ }^{38}$ Derrida comments, 'As soon as we admit this continuity of the now and the not-now...we admit the other into the self-identity of the Augenblick [instant]'. ${ }^{39}$ Perception, which for Husserl constitutes the now, occurs in a duration, since it is constituted by its relation to what is not perceived now.

Derrida thus finds that presence in both its spatial and temporal senses is a production of a difference that precedes it. He calls this difference différance. ${ }^{40}$ This well-known neologism, which I will render in English simply as 'differance', incorporates both senses of the French verb différer, 'to differ' and 'to defer'. The '-ance' ending adds a more dynamic sense to the existing participle 'différence'. In his 1968 lecture, 'Différance', Derrida writes that the ending indicates the middle voice, since the movement denoted is 'neither simply active nor simply passive..., saying an operation...that cannot be conceived either as the passion or as the action of a subject on an object'. ${ }^{41}$ In Speech and Phenomena he calls this differance a 'protowriting' (archi-écriture) at the origin of meaning, since it is the articulation of all that Husserl attempted

\footnotetext{
${ }^{36}$ Ibid. p. 64.

37 Ibid.

${ }^{38}$ Edmund Husserl. The Phenomenology of Internal Time-Consciousness, tr. James S. Churchill (Bloomington: Indiana University Press. 1964) p. 63. Cited in Derrida, Speech and Phenomena p. 65.

${ }_{39}$ Derrida, Speech and Phenomena p. 65.

${ }^{40}$ Ibid. p. 82.

"l Jacques Derrida, Margins' of Philosophy, tr. Alan Bass (New York and London: Harvester Wheatsheaf, 1982) p. 9.
} 
to exteriorise from speech as self-presence. ${ }^{42}$ Presence, Derrida concludes, is never itself, but 'always already a trace' of something else. He writes, 'The living present springs forth out of its non-identity with itself and from the possibility of a retentional trace', 43

Derrida's purpose in this reading, which establishes the structure of many of his future readings, is not to valorise the difference which Husserl has effaced in order to privilege presence. Derrida's point is that Husserl's text is organised by both elements that his reading has brought out. That is, Husserl both appeals to presence as a ground and shows that presence cannot function as a ground. He both affirms and denies presence, which Derrida concludes both is and is not. The point of Derrida's reading is that the text is generated by the undecidability between these two conflicting elements. This undecidability, he writes, is the condition of possibility of Husserl's phenomenology, preceding and generating the division of inside and outside or presence and difference, upon which phenomenology is structured. Differance, the trace, and the other synonymous terms Derrida develops, describe the coexistence of presence and non-presence as the condition of possibility for the conceptual division of the two, which generates metaphysics.

\section{Deconstruction}

I have examined Derrida's reading of Husserl in some detail because it is from this reading that Derrida derives the notion of presence as the essence of metaphysics and of the difference of which presence is a function. It is difficult

\footnotetext{
${ }^{42}$ Derrida. Speech and Phenomena p. 85.

${ }^{43}$ Ibid.
} 
to understand the motivation or provenance of Derrida's subsequent work without an awareness of how its fundamental motifs developed from his reading of Husserl. ${ }^{44}$ I will not linger over an exposition of fundamental early works such as Of Grommatology (1967), 'Plato's Pharmacy' (1968), or 'White Mythology' (1971), since many adequate introductions to these works already exist. ${ }^{45}$ I will briefly sketch some of the crucial points of these texts before passing on to the significance of Derrida's thought for literary criticism.

Of Grammatology is the closest to a systematic work in Derrida's oeuvre. It 'economises [the] development' of Speech and Phenomena, as Derrida put it in a contemporary interview. ${ }^{46}$ In it Derrida develops his understanding of the privilege of speech as the condition for presence and therefore for metaphysics. In anthropology, which in Claude Lévi-Strauss' structuralist version was the dominant mode of discourse in the 'human sciences' in France at the time, the term 'ethnocentrism' referred to the kind of discourse that used the writer's own society as a standard by which to judge the societies that were the object of his study. ${ }^{47}$ Derrida coins the term 'logocentrism' to describe the history of Western metaphysics, insofar as it uses the Greek concept of logos as a standard by which to judge language. ${ }^{48}$ We will discuss this concept in greater detail in Chapter 4 , but for now we can note that the term logos has the following chain of meanings:

\footnotetext{
${ }^{44}$ If this were not already plain to the attentive reader, Derrida suggests as much in Richard Kearney, Dialogues with Contemporary Thinkers: The Phenomenological Heritage (Manchester: Manchester University Press, 1984) p. 109, and in Positions, tr. Alan Bass (London: The Athlone Press, 1981) pp. 4-5.

${ }^{45}$ See Christopher Norris, Deconstruction: Theory and Practice, rev. ed. (London and New York: Routledge, 1991); Derrida (London: Fontana, 1987); Jonathan Culler, On Deconstruction: Theory and Criticism After Structuralism (Ithaca, NY: Cornell University Press, 1983).

${ }^{46}$ Derrida, Positions p. 5.

${ }^{47}$ In Le Geste et la Parole. of which the first part of Of Grammatology began in part as a review, André Leroi-Gourhan defines ethnocentrism as 'l'assimilation de l'ethnie à une sorte de "moi" idéal, réunissant les qualités du bien et du beau' (Paris: Presses Universitaires de France. 1965, p. 12).

${ }^{48}$ Jacques Derrida, Of Grammatology, tr. Gayatri Chakravorty Spivak (Baltimore and London: Johns Hopkins University Press, 1976) p. 3 passim.
} 
word, speech, reason, universal order represented in the mind of man, the incarnation of the purely transcendental, and hence the relation of these concepts. The Stoics linked logos endiathetos, reason present in the human mind, with logos prophorikos, reason expressed by the faculty of speech. ${ }^{49}$ This link between consciousness and speech is the essence of the logos that Derrida sees as the basis of the history of Western thought on both language and consciousness.

In Of Grammatology, Derrida focuses on certain texts particularly representative of the tradition of logocentrism insofar as they describe the secondarity or exteriority of writing to the logos. In each case he follows the pattern of reading that he used in Speech and Phenomena, isolating the function of presence as the organising factor of the discourse under examination and at the same time showing that presence, contrary to the intention of the writer, is described as a function of differance. Focussing on the Essay on the Origin of Languages (c. 1754-1763), Derrida reads Jean-Jacques Rousseau (1712-1778), whom he regards as representative of metaphysics from Descartes to Hegel, to show that he "valorises and disqualifies writing at the same time" ${ }^{50}$ On the one hand Rousseau 'condemns writing as destruction of presence' and on the other 'rehabilitates it to the extent that it promises the reappropriation of that of which speech allowed itself to be dispossessed'. ${ }^{51}$ Rousseau describes writing as a 'supplement' of speech, which as Derrida shows, can mean both an addition to a speech already complete or a filling up of a lack within speech. ${ }^{52}$ With great rigour, Derrida traces the structure of the double meaning of this term throughout

\footnotetext{
${ }^{49}$ See J.N.D. Kelly, Early Christian Doctrines, $5^{\text {th }}$ ed. (London: A. \& C. Black, 1977) pp. 17-19.

${ }^{50}$ Derrida, Of Grammatology p. 141.

${ }^{51}$ Ibid. p. 142.

${ }^{52}$ Ibid. p. 145.
} 
Rousseau's corpus, showing that what Rousseau declares to be exterior (for example, to nature) he also describes as interior (to it). He holds writing to be exterior to consciousness, and yet describes speech, which he holds to be present to consciousness, in the terms of writing and exteriority. Derrida writes:

He declares what he wishes to say...that articulation and writing are a post-originary malady of language; he says or describes what he does not wish to say: articulation and therefore the space of writing operates at the origin of language. ${ }^{53}$

Similarly, in his reading of Ferdinand de Saussure's Course In General Linguistics (1915), Derrida finds that

the alleged derivativeness of writing... was possible only on one condition: that the 'original', 'natural' etc. language had never existed, never been... untouched by writing. ${ }^{54}$

Derrida's conclusion in both cases is the same that he reached in his reading of Husserl, that the presence whose condition is speech is a function of the prior differential movement whose model is writing, which Derrida calls differance and arche-writing

\section{Derrida's Reading of Literary Texts}

Derrida's attention to the difference between what an author wants to say and what he says in fact makes his ideas a productive source for literary criticism. The concept of originary differance makes it impossible to maintain a rigorous distinction between philosophy and literature. An early response to Derrida, at its best in the work of Richard Rorty and of Geoffrey Hartman, made much of the deconstruction of the boundary between philosophy and literature to be found in

\footnotetext{
${ }^{53}$ Ibid. p. 229. 'Il déclare ce qu'il veut dire...; il dit ou décrit ce qu'il ne veut pas dire'.

${ }^{54}$ Ibid. p. 56.
} 
Derrida's work. ${ }^{55}$ Nevertheless, there is a 'distinctive nature' to Derrida's readings of 'literary' texts, to which he increasingly turned during the 1980 s, that merits examination here. ${ }^{56}$ When asked by Richard Kearney in his interview 'Deconstruction and the Other' (1981), whether he conceived literature as a nonsite of philosophy, Derrida replied, 'When I speak of literature (littérature) it is... an allusion to certain movements which have worked around the limits of our logical concepts, certain texts which make the limits of our language tremble'. ${ }^{57}$ He referred there to the works of Blanchot, Bataille and Beckett, and with the exception of an essay on Flaubert and a short piece on Romeo and Juliet, the literary texts Derrida has treated have tended to be modern or postmodern works in which textual play is a prominent feature, such as those of Joyce, Kafka, Ponge, Célan and Artaud. In his interview with Derek Attridge, 'This Strange Institution Called Literature' (1989), Derrida characterises these works as those that 'bear within themselves... a question' concerning the essence, origin and function of literature. He says, 'These texts... are themselves a sort of turning back on the literary institution' ${ }^{58}$ These modern and postmodern literary texts, in Derrida's reading, enact their own deconstruction, that is, they display the differance by which they are constituted, with much less resistance or repression than the more overtly 'metaphysical' texts of philosophical tradition.

\footnotetext{
${ }^{55}$ See Richard Rorty, 'Philosophy as a Kind of Writing: An Essay on Derrida', in Consequences of Pragmatism: Essays 1972-1980 (Brighton: Harvester, 1982), 'Deconstruction and Circumvention', Critical Inquiry 11 (1984) pp. 1-23. and Geoffrey Hartman, Soving the Text: Literature/DerridarPhilosophy (Baltimore and London: Joluns Hopkins University Press, 1981). ${ }^{36}$ See Timothy Clark, Derrida, Heidegger, Blanchot: Sources of Derrida's Notion and Practice of Literature (Cambridge: Cambridge University Press, 1992) p. 110.

${ }_{57}^{57}$ Kearney, Dialogues with Contemporary Thinkers p. 112.

58 Jacques Derrida, Acts of Literature, ed. Derek Attridge (New York and London: Routledge, 1992) p. 41.
} 
In his lecture 'Before the Law' (1982), Derrida reads Kafka's short text of that name, originally published as an independent piece and later incorporated in The Trial (1925). Derrida first describes a series of axioms that are commonly taken for granted in a reading of a literary work, that the text has a unity, an author, that its events are logically related in the form of a story (il y a du récit) and that it is named by its title. These axioms could be said to describe the laws of literature, he writes, in the sense that they guarantee the object that will be designated literary. Derrida poses two questions of such a designation, which is implicit in any work of 'literary' criticism: by what criteria is the text under discussion judged to be 'literature', and with what authority is that judgement to be made ${ }^{59}$ He writes that in order to conduct a reading of a literary work, the question of the relation between literature and law has to be asked. Since Kafka's text, which concerns a subject's relation to the law, describes this relation, Derrida asks whether the law and literature have 'shared...conditions of possibility'. ${ }^{60}$ Derrida draws out a series of differences within the identity of the Law as it is represented in the story. It is guarded by a series of doorkeepers, each more powerful than the last, the end of which series is not described: we are only told that the third doorkeeper is so terrible that the first cannot bear to look at him. The place 'before the Law', where both the first doorkeeper and the countryman who approaches him are found, Derrida finds to be structured by difference. The doorkeeper is described as 'before' the Law, but at the same time stands with his back to it. The countryman is described as before the Law but is prevented from seeing it. To be 'before' (devant) the Law, Derrida writes, is to be in its presence and at the same time not to be in its presence. The opposition

\footnotetext{
${ }^{59}$ Ibid p. 187

${ }^{60}$ Ibid. p. 191.
} 
described in the position of the protagonists, Derrida adds, is also described in the structure of the text. Its title, 'Before the Law', is identical with its first words, 'Before the Law [stands a doorkeeper]'. What must remain separate in the laws of literature, the title and the text, Derrida writes, here are also the same. The text articulates difference in the law in at least three senses, that of the law as its referent, that of the axioms by which a literary text is given an identity, and that of the legal rights attaching to the title of an author's work. The division of title and work, Derrida also points out, serves not only to lend an identity to a work but also serves a legal purpose, the title of a work allowing rights of authorship to be attributed to it, its classification in a library, and so on.

In the story, entry into the presence of the law is also deferred: the doorkeeper, speaking in the name of the law, tells the countryman that he may be granted admittance to it but not now. The latter accepts this prohibition, as it were forbidding himself from entering as he wishes. The Law, in short, orders the countryman not to come into its presence, but it is paradoxically present to him in the force of this order. Derrida calls this 'the originary division of the law'. He writes that, 'It is itself prohibited, a prohibited place. It forbids itself and contradicts itself by placing the man in his own contradiction: one cannot reach the law, and in order to have a rapport... with it, one must not have a rapport with the law' ${ }^{61}$ The essence of the law thus represented, Derrida writes, is that it has no essence. Instead it is structured by difference and deferral, which Derrida describes as its 'differantial topology'. 62

Returning to his question about the shared conditions of possibility of literature and the law, Derrida writes that the differance of the Law represented in Kafka's

\footnotetext{
61 Ibid. pp. 203-204.

${ }^{62}$ Ibid. pp. 206. 208.
} 
text also describes the constitution of the text itself. It does so by its 'unreadability', that is, 'the impossibility of acceding to its proper significance'. It is an enigmatic text, not yielding up its point of organisation, the Law, to which neither the countryman nor the reader ever gains access. The text 'say[s] nothing definite and present[s] no identifiable content beyond the story itself ${ }^{p} .^{63}$ The reference and the sense of the story alike are as 'inaccessible to contact' as the Law in the story. Just as the Law as legal force is present to the countryman in denying its presence to him, so the Law as the referent of the text is present in the text by its non-presence. Derrida suggests that this structure of nonreferential reference is the literary element of the text, which would remain after the registers of other discourses were subtracted. He writes that the concept of literature belongs to a certain period of legal history, since it is only in the modern period of that history that a work becomes 'literature' in the sense defined by the axioms of criticism with which Derrida began the essay. These axioms, according to Derrida, are guaranteed by means of a legal system that establishes property-rights to a work, the means of identifying it, the value of the author's signature and so on. Kafka's text, however, whilst constituted as a literary text by these laws, describes the absence at the heart of the presence of the law, describes the law as a non-entity. Derrida writes, therefore, that it occupies a position of 'subversive juridicity'. ${ }^{64}$ The concept of literarity is defined by at least two sets of laws and yet this text describes the non-identity of the concept and structure of law by which it is conceivable as literary. Although Kafka's text is particularly self-referential in this regard, Derrida writes that it nevertheless describes the non-essential essence of literature, which is also that

\footnotetext{
${ }^{63} \mathrm{Ibid}$. p. 211.

${ }^{64}$ Ibid. p. 216.
} 
of law. He writes that literature is related to the law in its capability to "play the law, repeating it while diverting or circumventing it' ${ }^{65}$

Derrida also addresses the relation of literature and law in his lecture "The Law of Genre' (1979), where he describes the 're-mark' (remarque), that is the trait that identifies a work as a member of a particular genre, whilst not itself belonging to any genre. A work both belongs and does not belong to a genre, Derrida argues, since its condition for membership of a genre is fulfilled by elements of it that are not a part of that genre. Derrida describes this identifying trait as an 'axiom of non-closure', constituting 'the condition for the possibility and the impossibility of taxonomy ${ }^{66}$ In both essays, Derrida finds literature to describe a 'supplementary' relation to law, that is, that it is both an external addition to and an internal substitution of the law. It can be described as the former insofar as it is constituted by a series of laws and therefore the concept of law, and as the latter insofar as its essence comprises a transgression of the laws and the concept of law by which it is constituted. Derrida offers the axiomatic definition that, "The law of literature tends, in principle, to defy...the law'. 67

\section{Deconstructive Literary Criticism}

Derrida's work has been appropriated by literary critics in a variety of ways and for a variety of purposes, such as in feminist and post-colonial methodologies. His thought was first introduced into the Anglo-American academy by comparative literary critics in the late 1970s, particularly by Paul de Man (1919-1983), who had been developing a related critical methodology since

\footnotetext{
65 Ibid.

${ }^{66}$ Ibid. p. 231.
} 
his doctoral dissertation in the 1950 s, as he recognised with hindsight in the preface to The Rhetoric of Romanticism (1983). He writes, 'I was apparently doing rhetorical analysis before I knew that such a thing existed by name... The methodological trend is unmistakable' ${ }^{68}$ De Man divided his time between European and American universities during the 1950s and 1960s, and was acquainted with contemporary French thought and with the phenomenological tradition from which Derrida's work derives.

In a section of Of Grammatology subtitled 'Question of Method', Derrida describes his reading method as one which 'aim[s] at a certain relationship, unperceived by the writer, between what he commands and what he does not command of the patterns of the language that he uses'. ${ }^{69}$ This relationship was also the goal of the method that de Man had been developing since the 1950s, which he referred to as rhetorical analysis. In fact, whilst it is customary to discuss de Man's ideas as a derivative of Derrida's, it is probable that Derrida had read de Man before vice versa. De Man's essay 'Heidegger's Exegeses of Hölderlin' first appeared in the Paris journal Critique in 1955, seven years before Derrida's first publication, and it is likely that Derrida read the essay, since Heidegger and literature were two of his main concerns at the time. De Man argues in the essay that 'Hölderlin says exactly the opposite of what Heidegger makes him say', concerning the relation of Being as presence to representation. ${ }^{70}$ He discusses a Derridean theme, that is, in a proto-Derridean form. De Man came to see the reading method described in Of Grammatology as a necessity of

\footnotetext{
${ }^{67}$ Ibid. p. 36.

${ }^{68}$ Paul de Man, The Rhetoric of Romanticism (New York: Columbia University Press, 1984) p. viii.

${ }^{69}$ Derrida, Of Grammatology p. 158.

${ }^{70}$ Paul de Man. Blindness and Insight: Essavs in the Rhetoric of Contemporary Criticism, $2^{\text {nd }} \mathrm{ed}$. (London: Routledge, 1983) p. 254.
} 
literary criticism, and he used Derrida's term 'deconstruction' to describe such criticism. For de Man, it was the only adequate mode of literary criticism, given the nature of language and in particular of literary language.

In 'The Resistance to Theory' (1982), de Man describes literature as the place where the freedom of language from referentiality that derives from the conventional relationship between a word and a thing, and results in a lack of epistemological validity, can be analysed. He writes:

Whenever [the] autonomous potential of language can be revealed by analysis, we are dealing with literariness, and...with literature as the place where this negative knowledge about the reliability of linguistic utterance is made available. $^{71}$

He emphasises that this is not a denial of the referential function of language but only of its authority as a model for cognition. There is no means of knowing, for de Man, whether language's mode of reference accurately describes the external world. He writes that it is... not a priori certain that literature is a reliable source of information about anything but its own language'. ${ }^{72}$ Deconstructive criticism, as practised by de Man, describes the way in which a literary text describes primarily its own rhetorical structure.

In 'Semiology and Rhetoric' (1973), de Man applies this method to passages by Yeats and Proust. Of Yeats' line, 'How can we know the dancer from the dance?' and the quartet which it concludes, he writes that there are two possible readings. On one hand, if taken as a rhetorical question, the line can signify the unity between a sign (the dancer) and its meaning (the dance). On the other hand, if taken more literally, it functions as a question as to how the two essentially different elements of sign and meaning, which are apparently identical, can be known individually in order to avoid the error of assuming that they are the same

\footnotetext{
${ }^{71}$ Paul de Man, 'The Resistance to Theory', Yale French Studies 63 (1982) p. 10.
} 
thing. ${ }^{73}$ De Man writes that the scheme of the first sense, which describes a moment of presence, is 'deconstructed' by that of the second. ${ }^{74}$ These two senses represent the possibility of two conflicting ideologies (of unity and of conflict) expressed in the quartet. They cannot be understood simply to co-exist in the poem, according to de Man, since 'the one reading is precisely the error denounced by the other'. ${ }^{75}$ Nor is there any means of deciding which is to be preferred, he writes. The work of criticism is to make clear that a device of syntax (the question) opens an undecidable antinomy between the operation of grammar (the question taken literally) and rhetoric (the question taken as a figure of speech, a 'rhetorical question') in the text. ${ }^{76}$ The work of criticism is to recognise that 'rhetoric... suspends logic and opens up vertiginous possibilities of referential aberration' ${ }^{77}$ De Man conducts a similar reading of a passage from Proust's Swann's Way (1913), and shows that in the passage, 'the assertion of the mastery of metaphor over metonymy owes its persuasive power to the use of metonymic structures', where metaphor stands for presence. ${ }^{78}$ A 'rhetorically conscious' reading of this kind, de Man writes, serves to bring out the authentic nature of the text's constitution, namely that it 'simultaneously asserts and denies the authority of its own rhetorical mode ${ }^{79}$ Deconstructive criticism, therefore, 'reveals the presence of this delusion [the authority of reference] and affirms it as the irreversible mode of [the text's] truth ${ }^{80}$ For de Man, such criticism

\footnotetext{
${ }^{72}$ Ibid. p. 10.

${ }^{73}$ Paul de Man, Allegories of Reading: Figural Language in Rousseau, Nietzsche, Rilke and Proust (New Haven and London: Yale University Press, 1979) pp. 11-12.

${ }^{74}$ Ibid. p. 12.

${ }^{75}$ toid.

${ }^{76}$ Ibid.

${ }^{17}$ Ibid. p. 10.

${ }^{78}$ Ibid. p. 15

${ }^{79}$ Ibid. p. 17.

${ }^{80}$ Ibid. p. 18.
} 
describes the 'state of suspended ignorance' with regard to truth in which a literary text is written. ${ }^{81}$

\section{(ii) Deconstruction and Christianity}

Clearly deconstruction poses a challenge to Christian hermeneutics. If Derrida's arguments are valid, they mean that the texts which express the intelligible content of the Christian faith do not convey a simple or stable quantity of meaning. In this section, I will examine the implications of deconstruction for Christian theology, and will suggest how, after Derrida, we can understand such discourse. I will also examine the implications of certain Christian theories of language, particularly that of negative theology, for the practice of deconstruction.

\section{Derrida and the Concept of Theology}

First, I will address the role of the term 'theology' in Derrida's thought. He takes from Heidegger the term 'onto-theology' as a description of metaphysics. Heidegger used the term to refer to the 'epoch' of metaphysics (from Plato to Nietzsche) in which Being is conceived as the ground (theion) of entities. In what Kant calls 'onto-theology', God is conceived as the highest being, the original being and the being of beings. ${ }^{82}$ For Heidegger, onto-theology is the kind of thought in which Being is conceived as God is in metaphysics, as the

\footnotetext{
${ }^{81}$ Ibid. p. 19.
} 
foundation of beings. ${ }^{83}$ Derrida uses the term 'theology' to signify the metaphysical definition of God as a being of the most perfect kind - highest, original and the ground of entities - as the paradigm of metaphysics. He writes:

The difference between the signifier and the signified belongs...to...the history of metaphysics, and in a more explicit and more systematically articulated way to the narrower epoch of Christian creationism and infinitism when these appropriate the resources of Greek conceptuality. ${ }^{84}$

Derrida's critique of structuralism, which was based on the linguistics of Ferdinand de Saussure (1857-1913), is that the latter's conception of the sign's composition by a concept (signified) and a sound-pattern (signifier) rests on the kind of distinction between the intelligible and sensible realms that Derrida had criticised in Husserl. He writes that this distinction is fundamental to Christianity insofar as its theology has followed such Hellenic distinctions. Thus Christian distinctions between God's infinity and temporal worldly existence, and between God's spirituality and the material world of his creation, are, in Derrida's view, particularly powerful means of attempting to establish the meaning of being as presence. He writes that metaphysics continued to be conceived along the axes of this Greek theology, where some kind of non-spatial, non-temporal 'living present' is distinguished from all worldly phenomena as their ground. Structural linguistics, with its appeal to the 'pure intelligibility' of the signified, was for Derrida (in 1967) the latest example of this tradition. He writes of the concept of the signified:

As the face of pure intelligibility, it refers to an absolute logos to which it is immediately united. This absolute logos was an infinite creative

\footnotetext{
82 Immanuel Kant, Critique of Pure Reason A 629/B 657-A 639/B 667, tr. and ed. Vasilis Politis, (London: J.M. Dent, 1993) pp. 427-433.

${ }^{83}$ See the section 'Onto-theology' in Kevin Hart, The Trespass of the Sign: Deconstruction, Theology and Philosophy (Cambridge: Cambridge University Press, 1989) pp. 75-96.

${ }^{84}$ Derrida, Of Grammatologv p. 13.
} 
subjectivity in medieval theology: the intelligible face of the sign remains turned towards the word [verbe] and the face of God. ${ }^{85}$

Hence his oft-quoted propositions, 'The sign and divinity have the same place and time of birth. The age of the sign is essentially theological' ${ }^{86}$

Most of the theological responses to Derrida have tended to agree that his attack on Greek theology is more or less justified, and that he teaches Christian theology to rethink its task, particularly in terms of its relation to its own representative function. In his essay on 'Hebraic and Christian Thinking in the Wake of Deconstruction' (1983), G. Douglas Atkins writes that Christian theology has 'moved beyond and indeed counter to the notion of religion created in the mode of Greek metaphysics' ${ }^{87}$ For Atkins, Derrida's thought parallels and supports the direction in which late twentieth-century theology was already moving, and he cites with approval the work of 'death-of-God' theologians like Thomas J.J. Altizer and Mark C. Taylor, who take as their point of departure the acceptance that 'a narrow Hellenic understanding of God has now been exploded'. ${ }^{88}$ Similarly, in his book Theology and Contemporary Critical Theory (1996), Graham Ward writes that Derrida is 'attacking a certain form of theology: the use of God within classical rationalism and Enlightenment Deism' ${ }^{89}$ He cites Derrida's mention of Leibniz and of Hegel as particularly paradigmatic examples of metaphysical theology, whose essence for Ward is a lack of reflection on the representative or referential function of its own language. He writes:

\footnotetext{
${ }^{85}$ Ibid.

${ }^{86}$ Ibid. p. 14.

${ }^{87}$ G. Douglas Atkins. 'Partial Stories: Hebraic and Christian Thinking in the Wake of Deconstruction', Religion and Literature 15 (1983) p. 7.

${ }^{88}$ Ibid. p. 10.

${ }^{89}$ Graham Ward, Theology and Contemporary Critical Theory (London: Macmillan, 1996) p. 24.
} 
God is not an object like other objects in the world, and therefore attention to proper nouns and predicates falsifies our representations of God as it distorts our understanding of language. ${ }^{90}$

For Ward, Derrida's concept of theology and its deconstruction, like the work of other critical theorists of Derrida's milieu, allows theology to remember that 'existence is not simply compositions on the basis of the periodic table', and to think of itself as a 're-enchantment' of the world, conceived as 'multiple worlds... constantly in process'. ${ }^{91}$

There is much to be said in favour of this kind of response to Derrida, which asserts that it is only a certain kind of metaphysical theology and not discourse on God per se that is open to deconstruction. It reminds us of the provisional nature of theological language with respect to its referents. God is not an object like other objects in the world, and Christian discourse does not refer to him as such. As John Macquarrie writes, in Principles of Christian Theology (1977), theological reflection soon leads to an awareness of the inadequacy of language for such reflection. ${ }^{92}$ Macquarrie, who identifies God with Being, continues:

Being is not a being, but since our language is adapted to talking about beings, then we must talk of Being in the language appropriate to beings. $^{93}$

This does not mean that theological language refers to nothing, or is meaningless, however. Derrida distances himself from those of his interpreters who assert that 'there is nothing beyond language... and other stupidities of that sort' ${ }^{94}$ The implication of Derrida's thought for Christian theology is that it must use the existing structure of language whilst at the same time pointing out the limits of that structure. As we saw in discussing Derrida's reading of Husserl, a

\footnotetext{
${ }^{90}$ Ibid. p. 40.

91 Ibid. p. 132.

92 John Macquarrie, Principles of Christian Theology, rev. ed. (London: SCM Press. 1977) p. 123.
} 
deconstructed text is not simply assigned to meaninglessness. The conclusion is not that the text is metaphysical and therefore not true. This approach Derrida describes as 'turning the page of philosophy (which usually amounts to philosophising badly)', by which he means that there is no question of a nonmetaphysical language in which one could dismiss or falsify metaphysics. ${ }^{95}$ Concerning theology as the paradigm of metaphysics, he writes, 'It is not a question of 'rejecting' these notions; they are necessary and...nothing is conceivable for us without them'. ${ }^{96}$ That is to say that despite the fact that a discourse might be organised around a notion of pure intelligibility or other point of presence that it nevertheles describes in the terms of all that it intends to keep from presence, this is still the only kind of discourse there is. It would make no sense to claim that it was false or even outdated in precisely the same kind of discourse at which one levelled those criticisms. Even metaphysical theology, therefore, in which God is conceived as a transcendental ground, is not simply false, according to Derrida. What is necessary, he writes, is:

to surround the critical [metaphysical-theological] concepts with a... discourse... to mark the conditions, the medium and the limits of their effectiveness... and, in the same process, designate the crevice through which the yet unnameable glimmer beyond the closure can be glimpsed. $^{97}$

Theology, that is, must be aware of the limits and conditions of its language at the same time as it continues to use it. If it is to tell us anything, it must do so in metaphysical language, since that is the only kind of language available. On the other hand, the most informative thing it can tell us is that the referential

\footnotetext{
${ }^{93}$ Ibid. p. 129.

${ }^{94}$ Kearney, Dialogues with Contemporary Thinkers p. 123.

${ }^{95}$ Jacques Derrida, Writing and Difference, tr. Alan Bass (London: Routledge, 1978) p. 288.

${ }^{96}$ Derrida, Of Grammatology p. 14.

${ }^{97}$ Ibid.
} 
function of its language is limited. It signifies neither nothing nor completely, and its referent is to be glimpsed most clearly at the limits of its reference.

The necessity of using language to emphasise its own limits Derrida describes as a result of the 'closure' (clotture) of metaphysics. In his book The Ethics of Deconstruction (1992), Simon Critchley examines the role of the concept of clôture in Derrida's thought. He points out that in addition to the fundamental spatial and temporal senses of the term (an enclosed space, the process of bringing to an end), it also refers to the space of a monastery or convent, and is etymologically related to cloitre or 'cloister'. ${ }^{98}$ Critchley is not concerned with this sense, but we can use it as a way of illustrating the significance of Derrida's thought for Christian discourse. A cloister is a place enclosed for contemplation, in which metaphysical categories are said not to apply. As Richard of SaintVictor writes, in Benjamin Minor (c. 1153-1162):

When the mind is carried away in contemplation it experiences how inadequate is human reason...Let no-one think he can penetrate the divine light by argument, or think that he may understand it by human reasonings. If that divine light might be approached by any discussions it would not be inaccessible. ${ }^{99}$

A cloister has an outside in the world of beings, but the contemplative experience inside it is indescribable in the language of beings. One of the most fundamental deconstructive methods is to trace the multiple senses of key terms in a discourse. So, when Derrida tells us that Christian theology operates within the cloture of metaphysics, that it uses the existing language despite its

\footnotetext{
${ }^{98}$ Simon Critchley, The Ethics of Deconstruction: Derrida and Levinas (Oxford: Blackwell, 1992) p. 62. Le Robert cites, from Martin du Gard: 'Il lui semblait qu'elle avait jusqu'alors vécu cloitrèe, et que les limites de sa clôture, reculant soudain, lui découvraient un horizon insoupçonée'.

${ }_{99}$ Richard of Saint-Victor, Selected Writings on Contemplation, tr. Clare Kirchberger (London: Faber and Faber, 1957) p. 112. For a more contemporary account, see Thomas Merton, Seeds of Contemplation (Wheathampstead: Anthony Clarke, 1961) p. 220: 'Would you call this experience?...It seems wrong to speak of it even as something that happens. Because things that
} 
inadequacy, we can, on his own terms, detect the sense of 'cloister' at work in this concept of 'closure'. ${ }^{100}$ That is to say that, whilst theological language operates within the necessarily metaphysical structure of language, it also obliquely indicates the God who cannot be named or conceived in such language. Thinking of differance, Derrida calls this referent la lueur de l'outreclôture, the glimmer from beyond the closure. ${ }^{101}$ We can take this phrase also to refer to God as the referent of theology. The significance of Derrida's thought for Christian discourse is that the limits of its referential function allow us to understand most about the God to whom it aims to refer.

This is not a new understanding of the nature of theological language. Its locus classicus is St. Thomas Aquinas' doctrine of analogy. I will examine Aquinas' theory of language in more detail in Chapter 4 , but for now we can note the following. Aquinas asks in Summa Theologiae 1a 13, 2, whether a word can be spoken of God 'substantialiter', that is, name His substance. Words for God, he answers, 'do say what God is [significant substantiam divinam]; they are predicated of him in the category of substance [praedicantur de Deo substantialiter], but fail to represent adequately what he is [deficiunt $a$ repraesentatione ipsius] $]^{102}$ Aquinas is a metaphysical theologian. He argues in the first question of the Summa that sciences do not argue to prove their premises but argue from their premises to prove questions within their field of inquiry. Theology is therefore a science, because it argues from its first principles, namely the articles of faith. The highest (suprema) science, Aquinas writes, is

happen have to happen to some subject, and experiences have to be experienced by someone. But here the subject of any divided or limited or creature experience seems to have vanished'.

${ }_{100}$ In the same way Kevin Hart traces the sense of 'Scripture' at work in Derrida's term écriture (The Trespass of the Sign pp. 47-64).

${ }^{101}$ Derrida De la Grammatologie (Paris: Éditions de Minuit. 1967) p. 25. 
metaphysics (metaphysica) because it concerns the first principles of the regional sciences, including theology. ${ }^{103}$ The five ways in which Aquinas asserts that it can be deduced that God exists, which he expounds in the next question, are all based on the concept of God as a transcendental ground. Nevertheless, when he comes to discuss the language in which God so conceived is represented, he asserts that its referential capacity is strictly limited. God, who for Aquinas is purely intelligible, nevertheless cannot be immediately understood through the language of theology. Theology can be said to refer, for Aquinas, but its signs are related to its referents 'in a higher way than we can understand or signify [eminentiori modo quam intelligatur vel significatur] ${ }^{104}$ On one hand, that is, Aquinas writes an edifice of metaphysical theology, in which the capacity of language to inform us about God is exploited to the full. On the other, when he considers the nature of this capacity, he recognises that it is extremely limited. Whilst theological language can indeed describe things that are true of God, for Aquinas, they are true in a way that cannot be known, and of which it cannot inform us. In the previous question, Aquinas compared our knowledge of God (in this life) to a bat's vision of the sun, which is invisible to it because it is too bright. ${ }^{105}$ So with the conceptual language of theology, it is only around the limits of the metaphysics of reference, that its referent can be guessed at. In his lecture 'Structure, Sign and Play in the Discourse of the Human Sciences' (1966), Derrida writes that 'language bears within itself the necessity of its own critique', and he describes Lévi-Strauss' procedure of 'conserving all the... old

\footnotetext{
${ }^{102}$ Thomas Aquinas, Summa Theologiae la 13, 2, tr. Herbert McCabe (London: Blackfriars, 1964) p. 55.

${ }^{103}$ Ibid. Ia 1. 8.

${ }^{104}$ Ibid. Ia 13, 2.
} 
concepts within the domain of empirical discovery while here and there denouncing their limits' ${ }^{106}$ In article 1a 13, 2 of the Summa Theologiae, Aquinas has done precisely this. He recognises the limits of the only possible mode of theology, and suggests that these limits are the point of its greatest capacity for reference.

The contemporary philosopher of religion most fully to develop this concept of theological language has been Jean-Luc Marion. ${ }^{107}$ In his book God Without Being (1982), he sketches the possibility of a non-metaphysical theology, in which God is conceived in another way than as the highest being. He denies that, with respect to God, it is 'self-evident that the first question comes down to asking... whether he is ${ }^{108} \mathrm{He}$ writes that 'under the conceptual names of 'God' only metaphysical 'idols' emerge, imposed on a God who is still to be encountered'. ${ }^{109}$ Marion argues that God is to be conceived 'according to the horizon of the gift' rather than according to the horizon of being, which is to say that God is to be known not insofar as he is but insofar as he gives himself. ${ }^{110}$ Marion writes that the concept of Being, when applied to God as his primary attribute, functions as an 'idol'. He defines an idol as a god whose limits are measured by the human capacity for vision. ${ }^{111}$ Since a concept is also limited by the mind's grasp of its object, Marion writes, when a concept is predicated of

\footnotetext{
${ }^{105}$ Ibid. Ia 12, 1. 'Sicut sol, qui est maxime visibilis, videri non polest a vespertilione propter excessum luminis'. See Ia 12, 7: 'sicut aliquis probaliter scire potest aliquam propositionem esse demonstrabilem, licet ipse eam demonstrative non cognoscat'.

${ }^{106}$ Derrida, Writing and Difference p. 284.

${ }^{107}$ See Jean-Luc Marion, God Without Being: Hors-Texte, tr. Thomas A. Carlson (Chicago and London: University of Chicago Press, 1991) pp. xxii-xxiv, for Marion's contention that his argument does not do violence to the thought of St. Thomas.

${ }^{108}$ Tbid. p. $\mathrm{xx}$.

${ }^{109}$ Tbid. p. xxi.

${ }^{110}$ Ibid. p. xxiv.

${ }^{111}$ Ibid. p. 14.
} 
God, 'this concept functions... as an idol'."12 The concept of God, in short, limits God to the mind's capacity to conceive, just as an idol limits God to the eyes' capacity to see. This is the essence of the metaphysical denomination of God, for Marion, and it cannot adequately represent God who is so conceived. He writes, 'To reach a nonidolatrous thought of God, which... releases 'God' from his quotation marks... one would have to manage to think God outside of metaphysics, ${ }^{113}$ This means thinking of God in another way than as Being. ${ }^{114}$ Marion writes that he must be conceived as radically unthinkable, 'an unthinkable that exceeds as much what we cannot think as what we can'. ${ }^{115}$ To denote God as unthinkable Marion borrows the technique Heidegger used in The Question of Being (1952) of crossing through a word so that it remains legible, in order to denote its inadequacy and at the same time its necessity. Heidegger had written and Derrida had borrowed this usage to describe the being of differance. ${ }^{116}$ Marion writes 'with a cross... which demonstrates the limit of the temptation...to blaspheme the unthinkable in an idol'. ${ }^{117}$ For Marion the unthinkable can be thought of as love, since love, unlike the concept, has no limits, not even its own, but 'gives itself only in abandoning itself, ceaselessly transgressing the limits of its own gift, so as to be transplanted outside of itself $^{118}$

\footnotetext{
112 lbid. p. 16.

${ }_{113}^{13}$ Ibid. p. 37.

${ }^{114}$ Ibid. p. 44

115 Ibid. p. 46.

${ }_{116}$ Derrida, Of Grammatology pp. 19, 44; Margins p. 6.

${ }^{117}$ Marion, God Without Being p. 46.
} 


\section{Derrida and Negative Theology}

Marion's argument that God cannot be thought in terms of Being is reminiscent of negative theology. It can be asked whether Derrida's critique of metaphysical language is a kind of negative theology. There are certainly similarities between the two discourses. As we have seen, Derrida's concept of differance as the movement that precedes and produces substance cannot be described in the language of substance. If differance produces Being, it cannot be said to be. In negative theology, since God produces Being, He too cannot be said to be. In his book Cliffs of Fall (1980), John Dominic Crossan writes that Derrida's thought 'leads straight into a contemporary retrieval of negative theology'.119 Both Derrida and the negative theologians assert the inadequacy of the metaphysical structure of language to describe the most fundamental realities accessible to knowledge. Both force language to its internal limit in order to focus on the epistemological value of its external limit. I will now turn to an examination of the relationship between these apparently similar concepts and practices.

Negative theology is something of a renegade term, whose precise definition has been given comparatively little attention, mainly I suspect because it is difficult to distinguish rigorously from its opposite, 'positive' theology. Neither the 16-volume Encyclopaedia of Religion (1987) nor the 18-volume New Catholic Encyclopaedia (1967) has an entry under 'Negative Theology' or under 'Apophatic Theology'. Nor for that matter do the older Encyclopaedia of Religion and Ethics or the Schaff-Herzog Encyclopaedia of Religious

\footnotetext{
${ }^{118}$ Ibid. p. 48.
} 
Knowledge, or the smaller Sacramentum Mundi. Only one of the five has an entry under 'Via Negativa'. Nevertheless, we need a working definition of the term, and I will elaborate an elementary one here. I will use the term to describe the attitude towards discourse on God that can be found in Pseudo-Dionysius (c. 500), John Scotus Eriugena (c.810-880), Meister Eckhart (1260-1327) and Nicholas of Cusa (1401-1464). Broadly speaking, this constitutes a denial of the value of analogy in speaking of God, which is the basis of positive or 'affirmative' theology. As we have seen, according to this doctrine, terms that apply to entities and that function according the limits of human conceptuality, can nevertheless be applied to God who is an entity beyond the human capacity to conceive. Although God's paternity, for example, is not paternity in the sense in which we conceive of it, we can say truly that he is a father in a sense analogous to our conception of the term's meaning. Negative theology denies that this is true. It denies the adequacy of conceptual language to impart any knowledge whatever of God, since God simply cannot be conceived by the human mind.

Negative theology is a method of denial and so called 'apophatic', from the Greek apophasis, or 'denial'. The nature of this denial varies among the writers in question. Nicholas of Cusa writes that to deny rather than affirm propositions of God is to speak more truly of Him. Although affirmative statements are necessary for worship, for Nicholas, nevertheless to deny conceptual predicates of God is truer than to affirm them. He writes that 'all affirmations that are made of God...are anthropomorphic' and therefore 'diminutives that fall infinitely

\footnotetext{
119 John Dominic Crossan, Cliffs of Fall: Paradox and Polyvalence in the Parables of Jesus (New York: Seabury, 1980) p. 11.
} 
short of His real name. ${ }^{120}$ Since God is infinitely greater than can be conceived, Nicholas writes, 'it is by the process of elimination and the use of negative propositions that we come nearer the truth about Him' ${ }^{121} \mathrm{He}$ concludes that 'in theology negative propositions are true and affirmative ones inadequate. ${ }^{122}$ Pseudo-Dionysius, on the other hand, does not go so far as to say that negative propositions of God are true. He employs a dialectical procedure of affirmation and negation, in which, whilst he finds negative propositions on the whole to be truer, he also finds it necessary to negate these negations. He concludes the Mystical Theology with a long list of what God is not, including the propositions that, 'It does not live, nor is it life. It is not a substance, nor is it eternity or time... There is no speaking of it, nor name nor knowledge of it'. Given this last, Dionysius writes:

We make assertions and denials of what is next to it, but never of it, for it is both beyond every assertion... [and] beyond every denial. ${ }^{123}$

For Dionysius, God cannot be adequately described either by positive or by negative propositions, because $\mathrm{He}$ is unknowable as an object by a subject. Dionysius writes that God can be related to only in another mode than conceptually, which cannot begin until one ceases to attempt to conceive of Him.

The most apparent similarity between this and Derrida's thought is the mutual attempt to think and describe something previous to being, which therefore is not, nor is it exactly previous, nor can it be described in the structure of language which is based on the priority of being. Derrida writes, 'The trace is nothing...it exceeds the question What is? and constitutes the condition of its possibility [la

\footnotetext{
${ }^{120}$ Nicholas of Cusa. Of Learned Ignorance, tr. Germaine Heron (London: Routledge and Kegan Paul, 1954) pp. 56, 55.

121 Ibid. p. 60 .

122 Ibid. p. 61 .

${ }^{123}$ Pseudo-Dionysius: The Complete Works, tr. Colm Luibheid (London: SPCK, 1987) p. 141.
} 
rend éventuellement possible]'. ${ }^{124}$ The same can be said of God by negative theology. Derrida has been aware of this topological similarity from his earliest writings. In 'Differance' (1968), he writes:

The detours, locutions and syntax in which I will often have to take recourse will resemble those of negative theology, occasionally even to the point of being indistinguishable from negative theology. ${ }^{125}$

He writes that describing differance is a question of delineating that 'differance is not, does not exist, is not a present-being' and also of delineating 'everything that it is not, that is, everything,' which amounts to saying that 'it has neither essence nor existence'. ${ }^{126}$ Pseudo-Dionysius adopts precisely the same approach with regard to the description of God. In the final chapter of the Mystical Theology, to which we alluded above, he writes of the Godhead, 'It is not a substance...It falls neither within the predicate of nonbeing nor of being', and lists many predicates that cannot be attributed to this non-entity. ${ }^{127}$

Derrida is at pains to assert, nevertheless, that despite this grammatical similarity, differance does not name God, not even in the manner of negative theology. His fundamental reason for this has not changed. According to Derrida, whilst negative theology denies the predicate of being to God, it does so in order to attribute him a superior mode of being. Referring apparently to Pseudo-Dionysius, Derrida writes that negative theologies are "concerned with disengaging a superessentiality beyond the finite categories of essence and existence' and that in them 'God is refused the predicate of existence only in

\footnotetext{
${ }^{124}$ Derrida, Of Grammatology p. 75.

${ }^{125}$ Derrida, Margins p. 6. The concept of differance is also related to that of energy in particle physics, in which matter and non-matter are considered functions of the movement of energy. 126 Tbid.

${ }^{127}$ Pseudo-Dionysius p. 141.
} 
order to acknowledge his superior...mode of being ${ }^{2} \cdot{ }^{128}$ Derrida is concerned with naming something of which onto-theology is a production, and finds that negative theology remains within the category of onto-theology. Whereas it names only a superior manner of being, Derrida is concerned with something altogether anterior to Being. In his essay 'How to Avoid Speaking: Denials' (1986), Derrida explicitly addresses the question of the relation between his work and negative theology, which by that time had been pointed out several times. He repeats his earlier assertion, insisting that "what I write is not "negative theology"'. ${ }^{129} \mathrm{He}$ writes that this is true 'in the measure to which negative theology seems to reserve beyond all positive predication, beyond all negation... some hyperessentiality, a being beyond Being' ${ }^{130}$ He writes, 'I would hesitate to inscribe what I put forward under the... heading of negative theology', because of the 'ontological wager of hyperessentiality' by which he finds negative theology to be characterised. ${ }^{131}$

Derrida cites Dionysius and Meister Eckhart by name as examples of this 'ontological wager'. He had long been aware of the passage in Eckhart's sermon Quasi stella matutina, on the nature of God, in which Eckhart writes:

In saying that God is not a being and that God is above being, I have not denied being to God; rather, I have elevated it in him. ${ }^{132}$

Derrida had cited this passage in a footnote to his essay on Bataille, 'From Restricted to General Economy' (1967), and had written, 'The negative moment of the discourse on God is only a phase of positive ontotheology'. ${ }^{133}$ In 'How to

\footnotetext{
${ }^{128}$ Ibid.

129 Harold Coward and Toby Foshay, eds., Derrida and Negative Theology (New York: State University of New York Press, 1992) p. 77.

${ }^{130}$ Ibid.

${ }^{131}$ Ibid. p. 78.

${ }^{132}$ Bernard McGinn. Frank Tobin and Elvira Borgstadt, eds., Meister Eckhart: Teacher and Preacher (New York: Paulist Press, 1986) p. 154.

${ }^{133}$ Derrida, Writing and Difference p. 337.
} 
Avoid Speaking', he quotes the passage at greater length in order to establish the same point. Clearly it is just when applied to the sentence Derrida cites. It seems more questionable, however, whether it is a just description of negative theology in general, as Derrida uses it. It would be hard to show that Dionysius, for example, thought that God was a superior being. Indeed the only passage in 'How to Avoid Speaking' that indicates this rests on a mistranslation. Derrida cites from the Mystical Theology a passage on the goal of the negative way as follows: to 'know unveiled...this unknowing which conceals in every being the knowledge one can have of this Being'. ${ }^{134}$ It appears that God is named as Being. Dionysius' text, however, reads, hina aperikaluptôs gnômen ekeinên tên agnôsian, tên hupo pantôn tôn gnôstôn en pasi tois ousi perikekalummenên. ${ }^{135}$ Colm Luibheid (1987) translates the passage as follows: 'that unknowing which itself is hidden from all those possessed of knowing amid all beings' ${ }^{136}$ John D. Jones (1980) renders it, "the unknowing which is covered round about by every knowledge in beings'. ${ }^{137}$ There is no phrase in Dionysius' Greek that corresponds to the words 'of this Being [de cet être]' in Derrida's translation, nor does the Mystical Theology ever describe God as Being. Derrida is not pressing the point about onto-theology when he cites this passage, but discussing the presence of God into which the negative way leads. Nevertheless, he cites Dionysius as well as Eckhart when he makes the claim that negative theology is a phase of onto-theology, and this is the only citation in his essay that could support that claim when applied to Dionysius.

\footnotetext{
${ }^{134}$ Coward and Foshay, Derrida and Negative Theology p. 80. Derrida's translation reads: 'connaître sans voile cette inconnaissance que dissimule en tout être la conmaissance qu' on peut avoir de cet être' (Psyché: Imventions de l'autre, Paris: Galilée, 1987 p. 543).

135 J.-Migne, ed. Patrologia Graeca III 1025 A94.

${ }_{136}$ Pseudo-Dionvsius: The Complete Works, tr. Colm Luibheid (London: SPCK, 1987) p. 138.
} 
In fact it is by no means clear that Dionysius' terms hyperousios (beyond being) and hyperousiôs (in a manner beyond being) refer to a mode of being that is simply being as we conceive it but in greater measure. In the introduction to his translation of the Divine Names and the Mystical Theology, John D. Jones writes of 'the negative character of [the prefix] hyper' in Dionysius. ${ }^{138}$ The Greek hyper means over, above, beyond. According to Jones, Dionysius' use of the term in the locutions 'beyond being', 'beyond having', 'beyond unity' and so on, refers to a non-entity on the far side of being, as it were, beyond and therefore no longer thinkable within the terms of being. This is certainly borne out by Dionysius' texts. He writes that God is kata mêden tôn ontôn ousa... auto de mê on, 'being according to no manner of being... and itself not being'. 139 Dionysius also writes, hyperkeitai tôn ousiôn hê hyperousios aoristia, "The unboundedness beyond entity lies beyond entities'. ${ }^{140}$ For Dionysius, that is, God is neither an entity nor does He have a mode of being, as Derrida suggests that Dionysius says He does. He 'is' not, in any sense, for Dionysius (mê on). In the fifth chapter of the Divine Names, on being, Dionysius describes God as hyperousiôs hyperôn, 'beyond being in a manner beyond being' ${ }^{141}$ This last construction seems to me decisive. For Dionysius, God is not only not a being, but nor is it true that he 'is' not a being, because he cannot be thought within the limits of the verb 'to be'. He 'is', in short, in a manner 'otherwise than being'. ${ }^{142}$

\footnotetext{
${ }^{137}$ Pseudo-Dionysius Areopagite: The Divine Names and Mystical Theology, tr. John D. Jones (Milwaukee, Marquette University Press, 1980) p. 215.

${ }^{133}$ Ibid. p. 31.

${ }^{139}$ Divine Names I.1 588B.

${ }^{140}$ Ibid.

${ }^{141}$ Ibid. V.8 824B.

${ }^{142}$ Kevin Hart's suggestion (The Trespass of the Sign p. 193) that 'Derrida assumes the Thomist reading of Pseudo-Dionysius' is well founded. St. Thomas writes, 'The reason why Dionysius says that... words are better denied of God is that what they signify does not belong to God in the way that they signify it but in a higher way' (Summa Theologiae Ia 13, 3). Eckhart takes a similar view: 'What Dionysius says... [i.e.] "Negations about God are true but affirmations are
} 
As Derrida's response develops, we can observe a lack of certainty concerning the onto-theological nature of negative theology developing along with the fundamental assertion that this is the case. From his earliest remarks Derrida was aware that negative theology was a plural discourse. In 'Differance' he referred to the 'order of the most negative of negative theologies'; in the Bataille essay he cited Eckhart as an 'example'; and in 'How to Avoid Speaking' he explicitly addresses the question of the 'dissimilar corpuses,... proceedings and languages' which comprise what is loosely called negative theology. In his letter to John P. Leavey, Jr., concerning the issue of Semeia on 'Derrida and Biblical Studies' (1981), Derrida writes of this plural discourse:

I believe that what is called 'negative theology'...does not let itself easily be assembled under the general category of 'onto-theology-to-bedeconstructed'.143

This assertion, whilst qualified with the phrases, 'I believe that...' and 'does not easily...', is nevertheless in striking contrast to the main burden of Derrida's remarks on negative theology. Similarly, in 'From Restricted to General Economy', he had written and repeated that negative theology 'perhaps' reserved a being beyond Being as the object of its discourse. He writes, 'Perhaps: for here we are touching upon the limits and the greatest audacities of discourse in Western thought'. ${ }^{144}$ And in 'How to Avoid Speaking', he writes that just as deconstruction remains within the closure of metaphysics, so his perception of

unsuitable"... is true about the mode of signifying in such sentences', and not about the things signified ('Commentary on Exodus' 78, Meister Eckhart: Teacher and Preacher p. 70). The problem seems to me larger than Hart suggests. however, that $\mathrm{St}$. Thomas simply misrepresents Dionysius. Although this is true, it is doubuful whether the difference between their views on this point is of practical significance. If, as St. Thomas says, words represent God but in a higher way than we can understand, this means that they represent Him in a way that we do not understand. Our knowledge of the meaning of a term when applied to God, therefore, is nothing, as with Dionysius. Although St. Thomas says that we can know that words for God do mean something, both assert that there is no question of knowing what it is.

${ }^{143}$ Jacques Derrida, 'Letter to Jolur P. Leavey, Jr.', Semeia 23 (1982) p. 61.

${ }^{144}$ Derrida, Writing and Difference p. 271. 
the ontotheological reappropriation of hyperessentiality in negative theology describes an equally inevitable closure. He writes:

If the movement of this reappropriation appears in fact irrepressible, its ultimate failure is no less necessary. ${ }^{145}$

This is to say that his charge that the apophatic description of God beyond being describes only a superior kind of being is the same kind of charge by which deconstruction could be called metaphysical. In both cases, the charge is not exactly false; it is simply that there could be no other state of affairs given the nature of language. Derrida concedes that whilst negative theology can do no other than describe being, because description cannot describe anything else, it can nevertheless be considered to draw attention to the limits of its necessarily metaphysical language in the manner of deconstruction.

Despite his partially justified assertions that negative theology remains within the metaphysics of substance, then, Derrida is also aware that this does not adequately describe all the modes of negative theology. Presumably it is as a result of this that he concedes an essential similarity between a certain moment of negative theology and his own thought with regard to the closure of metaphysics, namely that both internally question the metaphysical structure of language. Nevertheless, it would be going too far to say that Derrida writes negative theology. The negative way in theology is usually combined with a negative way of life, a form of ascetic practice integrated with the conceptual asceticism we have described. The term 'via negativa' is best understood as the combination of the two as a way of life whose goal is authentic relationship to God. Clearly Derrida is not concerned with modes of relationship to differance, but simply with opening a space in which it can be thought. Nevertheless, if we

\footnotetext{
${ }^{145}$ Coward and Foshay, Derrida and Negative Theology p. 79.
} 
consider the aspect of negative theology that is concerned only with discourse on God, it seems clear that its similarities to Derrida's work are more than accidents of grammar and syntax. We cannot simply say that differance names God, because neither can be named as such and because negative theology is concerned with non-conceptual relationship to God, but we can say that Derrida's thought opens up a space in which God can be thought, in the way that negative theology does. The space of differance, anterior to metaphysics and the language of metaphysics, is also the space of God in negative theology. By attending to the limits of the metaphysics of language, so that what is beyond its limits can be inarticulately gestured towards, Derrida elaborates a method in which God can be so gestured towards. In The Trespass of the Sign (1989), Kevin Hart argues that negative theology is a kind of deconstruction, of positive theology. I would add that in opening up a space to indiate the inconceivable in conceptual language, deconstruction provides negative theology with a significant methodological resource.

In this section, then, I have argued that deconstruction reminds us that Christian theology has a provisional nature. Its object cannot be denoted in the metaphysical structure of language, but since there is no other kind, it must express the experience of the community of faith in discourse determined by that structure. It is therefore most truly referential at the points where it displays the limits of its referential function. I have argued that Aquinas knew this before Derrida, and that Marion thinks it through most fully after him. This means that Christian criticism cannot be conceived as the application of doctrinal principles whose meaning is certain to literary texts whose meaning is not. Christian 
doctrine and literary texts share a common language, whose referential capacity both question in different ways. After deconstruction, Christian criticism must be thought of as a practice of faith rather than of knowledge. It will constitute an interpretation of literary texts from within a specific community of faith, whose own texts teach its members most where they display how problematically they teach. It must also be said that deconstruction tells us that this is true of all criticism.

I have also argued that deconstruction has the same effect, although not the same intent, as negative theology, inasmuch as it opens up a space in which the unthinkable God can be thought. This means that there is no reason why Christian criticism should not pursue the tension between intention and rhetoric in a literary text in the way that deconstruction does. We can follow Derrida in asserting that such texts indicate the limits of the structure of language and the mystery beyond these limits particularly clearly. We will depart from deconstruction in taking this mystery to be divine. Insofar as Christian criticism can deconstruct a text, that is, we can assert that the author's exploration of experience in the text has led him or her to the mystery of such experience that is a result of its divine creation.

\section{(iii) A Critique of Deconstruction}

Having described some of the implications of deconstruction for Christian literary theory, we should not go on to take it as the authority or critical orthodoxy it is sometimes presented to be. All but the most able and rigorous of 
deconstructive critics fall more or less frequently into the trap of taking Derridean conclusions as self-evident truths that do not need to be reached by argument. In this section, I will examine some of the more significant critiques of deconstruction, in order to show firstly that this is not the case, and secondly to expand on the position that Christian criticism should take with regard to deconstruction.

We should note first of all that there can be no question of making a charlatan of Derrida, as some critics have attempted to do. Few philosophers and fewer literary critics have contested his ideas with convincing counter-arguments. As deconstruction became a widely popular term in American literary criticism in the 1980 s, invoked to describe a wide variety of first principles and critical methods, many critics responded polemically in the name of humanism or of the analytical tradition. Works such as John $R$. Searle's essay, 'Reiterating the Differences: A Reply to Derrida' (1977) and John M. Ellis' book, Against Deconstruction (1989) are examples of this. Both charge Derrida with sophistry and intellectual sleight-of-hand but argue out of a distinct lack of acquaintance with and sensitive reading of Derrida's wide and difficult oeuvre. In the second chapter of Against Deconstruction, for example, entitled 'Deconstruction and the Nature of Language', Ellis attempts to controvert Derrida's fundamental position on the differantial nature of language. He argues that 'speech quite clearly existed long before the invention of writing', against Derrida's assertion in $O f$ Grammatology that speech has always already been writing. ${ }^{146}$ But in of Grammatology Derrida repeatedly distinguishes between writing in the 'narrow' and 'general' senses, that is between inscription and the interruption of self-

\footnotetext{
${ }^{146}$ John M. Ellis. Against Deconstruction (Princeton: Princeton University Press, 1989) p. 21.
} 
presence that inscription represents. He argues that the latter 'precedes' (that is, produces) speech considered as the mode of presence. The suggestion that Derrida asserts that historically inscription developed before enunciation misses the most fundamental point of his carefully-argued essay. Ellis' quarrels with over-enthusiastic importations of Derrida's ideas into literary criticism, that substitute assertion for argument in making extravagant claims, are often quite justified. But we should be clear that he does not engage with Derrida himself in any meaningful counter-argument, but rather proceeds by attributing to Derrida a sophistry and lack of argumentative rigour that simply cannot be found in his work. $^{147}$

\section{The Marxist Critique}

The Marxist critique of deconstruction should be taken more seriously, it seems to me, since it rests on the issue of the moral status of criticism. The essence of this critique is that the attention devoted in deconstructive criticism to the rhetorical constitution of a text prevents a proper attention to the social and historical situation in which the text was produced and in which it is read. Further, that as soon as one starts to understand these relations themselves as a kind of text, as deconstructive criticism does, and asserts their necessary failure to mean, one takes a conservative attitude towards them and the possibility of altering them for the better. We will examine the question of Marxist morality in more detail in the next chapter, but for now we can note that since Christian

\footnotetext{
${ }_{147}$ Christopher Norris' review of Ellis' book, 'Limited Think: How Not to Read Derrida. Diacritics 20 (1990) pp. 17-36, presses this point at length.
} 
morality must involve a commitment to justice in social relations, then Christian literary theory cannot imply that this is not possible.

This kind of critique applies most closely to the work of Paul de Man. In his book Criticism and Social Change (1983), Frank Lentricchia writes that de Man, despite being thought of as a radical by humanist critics, is in fact 'the theorist who elaborated the cagiest argument for the political defusion of writing and the intellectual life'. ${ }^{148}$ The effect of de Man's work, Lentricchia writes, is to demonstrate that the link between the literary and the political realms is insignificant, that 'intervention...can make no difference', and to effect 'the paralysis of praxis'. ${ }^{149} \mathrm{He}$ describes the 'epistemology of failure' that has underwritten de Man's work since his doctoral thesis, according to which the clearest self-knowledge is that self-knowledge is not possible. The 'aporia' which results, in de Man's thought, means that action cannot be based on knowledge, according to Lentricchia. Of de Man's use of the term 'paralysis' to describe the irreducible contradiction between intention and rhetoric, Lentricchia writes:

He means the paralysis of action, which will deny lucidity to the intellect and guarantee in the end that no mind knows what it is doing. ${ }^{150}$

He describes the 'political allegory' of de Man's reading of Nietzsche in his essay 'Literary History and Literary Modernity' (1969), in which the attempt to break from history is seen always to be assimilated back into history. Lentricchia describes this view of history as 'fatalistic', in which action and modernity are 'naive illusions'. 151 The last sentence of de Man's essay reads, 'If we extend

\footnotetext{
${ }^{148}$ Frank Lentricchia. Criticism and Social Change (Chicago and London: University of Chicago Press, 1983) p. 39.

149 Ibid. p. 40.

150 Ibid. p. 43

${ }^{151}$ Ibid. pp, 48, 45.
} 
[the] notion [of literary history] beyond literature, it merely confirms that the bases for historical knowledge are not empirical facts but written texts, even if these texts masquerade in the guise of wars and revolutions?. ${ }^{152}$ Lentricchia comments, 'De Man... is saying that... history is an imitation of what he has defined as the literary', namely the place of the paradoxical mutual implication of history and modernity. ${ }^{153}$ Lentricchia calls this 'the most genuine meaning of political conservatism'. ${ }^{154} \mathrm{He}$ concludes that deconstruction successfully criticises the epistemology of representation, but fails to describe the real issue, the politics or 'social work' of representation. For Lentricchia this is to confuse 'the act of exposing epistemological fraud with the neutralisation of political force'. ${ }^{155}$ He writes:

Politically, deconstruction translates into that passive kind of conservatism called quietism.... In Paul de Man it teaches the many ways to say that there is nothing to be done. ${ }^{156}$

In his essay 'Capitalism, Modernism and Postmodernism' (1985) Terry Eagleton pursues a similar criticism of de Man's essay. He describes de Man's view of literature, fairly enough, as 'the ceaseless incapacity ever quite to awaken from the nightmare of history'. ${ }^{157} \mathrm{He}$ paraphrases de Man's assertion that his view of literary history could be paradigmatic for history in general as an assertion that 'though we will never abandon our radical political illusions... such actions will always prove self-defeating' ${ }^{158}$ Eagleton points out that de Man is at odds with the Marxist view of history, in which actions may be based on knowledge and history may be emancipatory. He writes:

\footnotetext{
152 De Man, Blindness and Insight p. 165.

${ }^{153}$ Lentricclia, Criticism and Social Change p. 49.

154 Ibid. p. 50.

${ }^{155}$ Ibid.

${ }^{156}$ Ibid. p. 51.

${ }^{157}$ Terry Eagleton, Against the Grain: Essavs 1975-1985 (London: Verso, 1986) p. 136.

${ }^{158}$ Ibid. p. 137.
} 
It is only by virtue of an initial Nietzschean dogmatism - practice is necessarily self-blinded, tradition necessarily impeding - that de Man is able to arrive at his politically quietistic aporias. ${ }^{159}$

In his essay 'The Critic as Clown' (1986), Eagleton discusses the 'political implications of de Man's misreading of Empson' in 'The Dead-End of Formalist Criticism', in which de Man had written that 'Marxism is ultimately a poetic thought that lacks the patience to pursue its own conclusions to their end ${ }^{2} .60$ Eagleton writes:

If the ironies of pastoral are allegorical of the critic's relation to society...then it is the uncrossable gulf between them that de Man wishes to reaffirm. ${ }^{161}$

He translates the disjunction in de Man's thought between consciousness and being into the position that 'the intellectuai...should really have nothing to say'. $^{162}$

The most extreme form of this kind of criticism of de Man came after the disclosure of his wartime journalism in 1987, in which it was discovered that de Man had written for collaborationist newspapers in his native Belgium up to 1942. In a fulminating essay entitled 'Paul de Man and the Politics of Deconstruction' (1988), David H. Hirsch took the view that 'the connection between Paul de Man's deconstructive criticism and his Nazi past...starts to make a great deal of sense'. ${ }^{163}$ In his analysis of de Man's essay 'Literary History and Literary Modernity', Hirsch writes that 'de Man attacks the concept of "the past", in order to assuage the guilt of his participation in European history. ${ }^{164}$ Concerning de Man's position on the absolute uncertainty of a text's

\footnotetext{
${ }^{159}$ Ibid. p. 138.

${ }^{160}$ De Man, Blindness and linsight p. 241.

${ }_{161}^{161}$ Eagleton, Against the Grain p. 158.

162 Ibid. p. 161.

${ }^{163}$ David H. Hirsch, 'Paul de Man and the Politics of Deconstruction', Sewanee Review 96 (1988) p. 331.

${ }^{164}$ Ibid. p. 333.
} 
reference, Hirsch writes, 'If one accepts this assumption, then history itself, and with it de Man's own Nazi past, has been obliterated' ${ }^{165}$

Clearly there is little to be gained in using emotionally-loaded terms like 'Nazi' of deconstruction. When Eagleton describes de Man's work as 'postfascist', he refers to the post-war climate of anti-ideological scepticism in which he locates de Man's thought, rather than implicating deconstruction in a form of government. ${ }^{166}$ The substance of Hirsch's argument, once one subtracts his psychological speculations about de Man's sense of guilt and mode of assuaging it, is that with which we are now familiar, that deconstruction does not allow for the possibility of reliable knowledge of history or of action based thereon. This is a justified criticism. Eagleton and Lentricchia do no violence to the thought of de Man as they expound his essays, and we should take their critique to qualify our conclusions on the potential use of deconstruction for Christian criticism. We should bear in mind Anthony Thiselton's point in New Horizons in Hermeneutics (1992) on the evaluation of deconstruction, that

the use of a hermeneutic of suspicion as a method is an entirely different matter from the transformation of the principle of suspicion into a worldview. ${ }^{167}$

Whilst deconstructive criticism can yield some significant insights which Christian literary can use, that is, we should not take it to be the only authentic relation possible to a literary text. Since it is unacceptable to Christian morality, as to Marxist, to suggest that it is useless to attempt to improve the configuration of social relations, we cannot fully subscribe to a critical method such as de Man's, which derives from a world-view in which this is implied.

\footnotetext{
165 Ibid. p. 334.

${ }^{166}$ Eagleton, Against the Grain p. 165.

${ }^{167}$ Anthony C. Thiselton, New Horizons in Hermeneutics (London: Harper Collins. 1992) p. 126.
} 
Eagleton tends to exempt Derrida from this kind of critique, writing that 'whatever his practice, he is quite evidently some kind of Marxist sympathiser'. In his essay 'Frère Jacques: The Politics of Deconstruction' (1984), Eagleton evinces certain reservations about Derridean deconstruction, but on the whole recognises the genuinely Derridean position that 'deconstruction...insists not that truth is illusory but that it is institutional'. ${ }^{168}$ Derrida's main political crime, for Eagleton, is his lack of lasting protest at the appropriation and domestication of his thought by the rhetorical analysis of the Yale critics. In 'Deconstruction and the Other', Derrida himself says, 'I have never succeeded in directly relating deconstruction to existing political codes and programmes'. ${ }^{169}$ These codes, he writes, are not commensurate with deconstruction, since they are formulated on the basis of a metaphysics of substance. Derrida acknowledges that this can give the impression that deconstruction is apolitical, but he writes that such an impression prevails only because 'all of our political codes and terminologies still remain fundamentally metaphysical'. ${ }^{170}$ This leaves him in a position he describes as a 'dual allegiance':

I try where I can to act politically while recognising that such action remains incommensurate with my intellectual project of deconstruction. ${ }^{171}$

\footnotetext{
${ }^{168}$ Eagleton, Against the Grain p. 85.

${ }^{169}$ Keamey, Dialogues with Contemporary Thinkers p. 119.

${ }^{170}$ Ibid. p. 120.

${ }^{171}$ Ibid. Critchley (The Ethics of Deconstruction pp. $188 \mathrm{ff}$.) discusses the 'impasse of the political' he finds in Derrida's work, which 'fails to navigate the treacherous passage from ethics to politics, or...from responsibility to questioning' (p. 189). He means that the undecidability produced by deconstructive reading does not translate into the political necessity for decisive action.
} 


\section{The Hermeneutic Critique}

At the 1981 symposium 'Text and Interpretation', at Paris' Goethe Institute, Derrida and Hans-Georg Gadamer (b. 1900) met in order that a debate between deconstruction and Gadamer's philosophical hermeneutics might develop. In fact this did not occur, but, as Fred Dallmayr puts it in his essay on the encounter, 'the two spokesmen seemed more intent on reiterating firmly held positions than on exposing them to mutual testing and scrutiny'. ${ }^{172}$ Nevertheless, as Gadamer sought to defend his position against Derrida's charge that hermeneutics remains within the metaphysics of presence, some important criticisms of deconstruction emerged.

In the essay he contributed to the symposium, 'Text and Interpretation' (1981), Gadamer outlines his view of language and of understanding, with Derrida's critique of the latent logocentrism of hermeneutics in mind. The essence of his response is that Derrida ignores that the fundamental condition of any linguistic act is the will to understand and to be understood by an interlocutor. We will examine Gadamer's thought more closely in Chapter 5 , but for now we can note that he sees the essence of language as dialogue, "the living dialogue in which the Socratic-Platonic movement of thought took place'. ${ }^{173}$ For Gadamer, that is, understanding is not to be conceived as the decoding of a quantum of meaning encoded in a statement, but as a developing product of interpersonal relationship that unfolds in the process of dialogue. The model for this view is Platonic dialectic, in which Socrates and an interlocutor develop their mutual

\footnotetext{
${ }^{172}$ Diane P. Michelfeider and Richard E. Palmer. eds., Dialogue and Deconstruction: The Gadamer-Derrida Encounter (New York: State University of New York Press, 1989) p. 77.

${ }^{173}$ Ibid. p. 23.
} 
understanding of a question through the exchange of questions and answers. Gadamer writes:

What we find happening in speaking is not a mere reification of intended meaning, but... a continually recurring temptation to engage oneself in something or to become involved with someone. ${ }^{174}$

Most of his essays on Derrida are concerned with defending the position that this understanding of language does not relapse into a metaphysics of substance. His criticism of Derrida's own position is primarily that the latter's assertion of the dispersal or 'dissemination' of meaning produced by differance forgets the dialogical situation of language. In order to engage in dialogue at all, Gadamer writes, "both partners must have the good will to try to understand each other'. ${ }^{175}$ For Gadamer, Derrida places too much emphasis on the semantic aspect of language, that is, on the relation between signs and meanings. What he forgets, Gadamer writes, is the hermeneutic dimension, the will to communicate, upon which the semantic relation is contingent. Gadamer accepts Derrida's critique of the metaphysical structure of language (it derives from Heidegger, to whose thought Gadamer is also deeply indebted), and denies that texts, conversations or even inner monologue employ signifiers that immediately convey signifieds. In his reply to Derrida's questions on his paper, he writes:

I would not want to say that the solidarities that...make [people] partners in a dialogue... are sufficient to enable them to achieve understanding and total mutual agreement... The same would apply with regard to the inner dialogue the soul has with itself. ${ }^{176}$

He does not criticise the concept of differance in the name of the clarity of meaning, but because he finds a prior agreement and will to understand another underlying all language-use, which allows an authentic progression through the

\footnotetext{
${ }^{174}$ Ibid. p. 26.

${ }^{175}$ Ibid. p. 33.

${ }^{176}$ Ibid. p. 57.
} 
conceptual instabilities of language as a sign-system. This is what he means in his essay 'Hermeneutics and Logocentrism' (1987), when he writes of Derrida's improper 'dependence on the semantic starting-point... in his view of language', and that 'the unavoidability of the hermeneutic standpoint' is the essence of his critique of Derrida. ${ }^{177}$

In his response to Gadamer's initial paper, 'Good Will to Power (A Reply to Hans-Georg Gadamer)' (1981), Derrida asked whether 'the precondition of Verstehen [understanding], far from being the continuity of rapport [as Gadamer suggests]... is not rather the interruption of rapport'. In his response, 'Nevertheless: The Power of Good Will' (1981), Gadamer replied that 'whoever opens his mouth wants to be understood; otherwise, one would neither speak nor write'. He points out that this occurred even in what limited dialogue took place between Derrida and himself: 'Derrida directs questions to me and therefore he must assume that I am willing to understand them ${ }^{178}$ He writes of Derrida and Nietzsche, whom Derrida invokes against Gadamer's conception of will, 'Both of them are mistaken about themselves. Actually, both speak and write in order to be understood'. ${ }^{179}$

One does not have to accept Gadamer's Heideggerian view of understanding as a fundamental category of human existence in order to recognise that his concept of the prior will to understand functions as a serious criticism of deconstruction. We should learn from it not to accept the authority with which deconstructive criticism often asserts that the rhetorical aporias it discovers in texts function as proofs that the text fails to mean or to refer to anything beyond these aporias. Christian criticism should be attentive to the hermeneutic as well as to the

\footnotetext{
${ }^{177}$ Ibid. p. 125.

178 Ibid. p. 55.
} 
semantic dimension of a text, that is, to the part it plays in a dialogic or communicative relation with past texts, its history of readings and our own reading of it. We will discuss the use of Gadamer's thought for Christian literary theory in Chapter 5. Here we can note that his critique of Derrida reminds us that where we use deconstructive methodology, we should be aware that it treats the text in isolation from the human dimension of communication. Christian literary theory should be attentive to the communal nature of human existence and attend to the function of the text as an utterance in and for the sake of community, or 'solidarity', as Gadamer puts it. We should be attentive to the mutually transformative dialogue enacted between the text and criticism, of which rhetorical analysis forms only a part.

${ }^{179}$ Tbid. p. 57 


\section{On Marxism}

I will now move on to an analysis of some of the more influential Marxist literary theories and critical practices. As in the previous chapter, I shall have two main concerns. Firstly, I will examine the some of the relations between Marxism and Christianity, in order to assess the degree to which Christian literary theory can and should use some of its insights. Secondly, I will offer a critique of certain Marxist theories, in order to establish that, whilst there is much that Christian criticism can and should learn from them, like deconstruction they cannot be taken as finally authoritative for literary theory. As before, I will begin this study with an introduction to the Marxist literary theories with which I will be concerned.

\section{(i) An Outline of Marxist Literary Theories}

The term 'Marxist literary theory' encompasses a wide and heterogeneous body of works. These works have almost nothing in common except their attempt to understand literary texts from a Marxist perspective. One reason for this is that Marxism is a developing tradition of thought, and as its fundamental socio-economic principles evolve, so does the literary criticism contingent upon these principles. I do not have space here to represent this tradition fully, so I have selected for exposition those critics whose work bears most relevance to the contemporary literary-critical scene. Despite the profundity of the work of Georg Lukács, for example, it is not represented here, since few readers are likely at 
present to encounter criticism that is substantially indebted to it. In this section, I will focus on those critics who maintain a clear allegiance to the thought of Marx, and whose theories are relatively current.

\section{Karl Marx}

Marxist literary theory describes the consequences of the thought of Karl Marx (1818-1883) for our understanding of literary texts. Although there are many fragments of literary criticism in Marx's works, some of which are occasionally defended by contemporary critics, most Marxist criticism constitutes an application of Marx's philosophy of history to such texts. ${ }^{1}$ I will begin with an introduction to some of the main points in this philosophy. The Economic and Philosophical Manuscripts of 1844 (first published in 1932) represent the first draft of the major work on economics that occupied Marx for most of his life. ${ }^{2}$ They were written while Marx was still influenced by the humanism of Ludwig Feuerbach (1804-1872). There are three main divisions in the subject-matter of the manuscripts: a critique of political economy, particularly that of Adam Smith and David Ricardo, a discussion of communism and of private property, and a critique of Hegel's dialectic. The essence of Marx's critique of the political economy of Smith and Ricardo is that it does not account for men as living human beings, but as abstract elements of the

\footnotetext{
'See Marx and Engels, On Literature and Art, ed. Stefan Baxandall and Lee Morawski, (St. Louis: International General, 1973) for Marx's own writings on literature. Terry Eagleton defends his argument for the enduring value of Greek art in Marxism and Literary Criticsm (London: Routledge, 1976) pp. 9-16.

¿ See David McLellan. Karl Marx: His Life and Thought (London: Macmillan, 1973) pp. 104128.
} 
economic system. He is critical that they cannot explain the origins of the system they describe. He writes:

Political economy [i.e. economics] starts with the fact of private property, it does not explain it to us. ${ }^{3}$

For Marx, the present economic system has a history, which needs to be accounted for rather than presupposed. Marx describes the human reality of labour in industrial capitalist society as alienated labour. By this he means that 'the object that labour produces, its product, confronts it as an alien being, as a power independent of the producer' ${ }^{4}$ As a result, the worker is alienated not only from the product of his labour but also from himself, since he does not confirm or fulfil himself in any way in this kind of work. He is not 'at home', as Marx puts it, in his work. ${ }^{5}$ Marx writes of these and other alienations, that political economy hides them, 'by not considering the immediate relationship between the worker...and production'.6 For Marx, man should be his own creator, developing himself by transforming nature; but in capitalist society the product of his labour, properly his own, has become set over against him, as if an independent object. This objectification allows for the appropriation of the products of labour in the form of private property. Marx's solution to the problem of alienation, described in the second section of the manuscripts, is communism. He describes this as 'the positive abolition of private property and thus of human self-alienation and therefore the real reappropriation of the human essence by and for man? ${ }^{7}$

\footnotetext{
${ }^{3}$ Karl Marx. Selected Writings, ed. David McLellan (New York: Oxford University Press, 1977) p. 77.

${ }^{4}$ Ibid. p. 78 .

${ }^{5}$ Ibid. p. 80.

${ }^{6}$ Ibid. p. 79.

${ }^{7}$ Ibid. p. 89.
} 
By the time he and Friedrich Engels (1820-1895) wrote The German Ideology (1846), Marx had abandoned the concept of 'the human essence', which he had taken from Feuerbach, and was concerned to distinguish his 'materialist conception of history' from Feuerbach's 'objective' mode of materialism. ${ }^{8}$ The first premises of this conception, Marx and Engels write, are not abstractions from concrete existence but 'real individuals, their activity and the material conditions under which they live'. The first fact of history is 'the physical organisation of these individuals and their consequent relation to the rest of nature'. ${ }^{10}$ Men become men, according to Marx and Engels, by producing their means of subsistence, or 'indirectly producing their actual material life'. "The way in which they are able to do this depends upon the natural resources at their disposal and on the way in which they organise themselves. Marx and Engels write, 'The nature of individuals thus depends on the material conditions determining their production'. ${ }^{12}$ After a brief history of the development of social forms, Marx and Engels conclude:

The fact is...that definite individuals who are productively active in a definite way enter into these definite social and political relations. ${ }^{13}$

Social and political structure, for Marx and Engels, is determined by the sum of production relations in a society. Ideas are produced in the same way. Marx and Engels write:

Men, developing their material production and their material intercourse, alter, along with this, their real existence, their thinking and the products

\footnotetext{
${ }^{8}$ See 'Theses on Feuerbach' I, in ibid. p. 156.

${ }^{9}$ Ibid. p. 160 .

${ }^{10}$ Ibid.

11 Ibid.

12 Ibid. p. 161.

${ }^{13}$ Karl Marx and Friedrich Engels, Basic Writings on Politics and Philosophy, ed. Lewis S

Feuer (New York and London: Doubleday, 1989 p. 246.
} 
of their thinking...Life is not determined by consciousness but consciousness by life. ${ }^{14}$

This is the basis of Marx's and Engels' 'materialist conception of history', according to which historical analysis must first establish the history of the production relations of a given society, and then demonstrate how its various forms of consciousness - religion, philosophy, art and so on - have developed from those production relations. ${ }^{15}$

The point of this kind of history is to recognise that, as Marx and Engels write in the Communist Manifesto (1848), 'The history of all hitherto existing society is the history of class struggles'. ${ }^{16}$ In the Manifesto, drawn up as an embodiment of the ideas of the Communist League, Marx and Engels give a brief history of social forms since the feudalism of the Middle Ages, and describe the present opposition of the bourgeois and proletarian classes. Engels adds this note to the 1888 English edition:

By 'bourgeoisie' is meant the class of modern capitalists, owners of the means of social production and employers of wage labour. By 'proletariat', the class of modern wage labourers who, having no means of production of their own, are reduced to selling their labour power in order to live. ${ }^{17}$

The bourgeois class, Marx and Engels write, has revolutionised the feudal means of production, to mankind's immense potential benefit. They write, 'The bourgeoisie, during its rule of scarce one hundred years, has created more massive and more colossal productive forces than have all preceding generations together'. ${ }^{18}$ Unlike previous dominant classes, Marx and Engels continue, the

\footnotetext{
${ }^{14}$ Ibid. p. 247.

15 Ibid. p. 257.

${ }^{16}$ Ibid. p. 7.

${ }^{17}$ Tbid. The term 'bourgeois' originally applied to the middle class of citizens in a French city or burgh, neither peasants nor gentry. The tern 'proletarian' comes from the Latin proletarius, a member of the lowest class of Roman citizen, who contributed only his offspring (proles) to the state.

${ }^{18}$ Ibid. p. 12.
} 
bourgeoisie needs constantly to revolutionise its own means of production. Greater productivity and expanding markets are constant necessities for the industrial merchant class to maintain its profits. Where one or the other cannot immediately be produced, bourgeois profits are endangered. Marx and Engels write, 'The conditions of bourgeois society are too narrow to comprise the wealth created by them'. ${ }^{19}$ They compare the class to a sorcerer no longer able to control the spells he has called up. Most significantly, in Marx and Engels' view, the bourgeoisie has called into existence the proletarian class, "who live only so long as they find work and who work only so long as their labour increases capital' ${ }^{20}$ Enslaved at work by industrial machinery and by the bourgeois manufacturer, whose ownership of the means of production is legalised by the state, the industrial labourer becomes a pauper, totally dependent for his means of subsistence on the fluctuations of the market to which his labour contributes. As Marx and Engels put it, the bourgeoisie is 'incompetent to assure an existence to its slave within his slavery' ${ }^{21}$ The aim of the Communists is to organise the proletariat into a class in order to abolish the bourgeois system of propertyrelations and to make common property the capital that is in fact, although not by law, already common property. They intend to abolish 'the miserable character of this [bourgeois] appropriation [of the products of labour] under which the labourer lives merely to increase capital', and to bring about 'an association in which the free development of each is the condition for the free development of all'.22 This revolution will take place by means of a seizure of political power by the proletariat. For Marx and Engels, the bourgeois mode of

\footnotetext{
${ }^{19}$ Ibid. p. 13

20 Ibid. p. 14

${ }^{21}$ Ibid. p. 19

22 Ibid. pp. 22, 29.
} 
production has both necessitated such a revolution and made it possible. As Marx puts it in Capital (1867), it is a question of '[shortening]...the birth pangs' of the natural development of society. ${ }^{23}$

\section{Louis Althusser}

After Marx's death, Engels' interpretation of his thought determined the orthodoxy of European socialist parties until the First World War. He argued that the universe was governed by objective and predictable dialectical laws, and that historical materialism was the law governing society. ${ }^{24}$ In 1923, Georg Lukács’ History and Class Consciousness revived the Hegelian dimension of Marxism, arguing that reality can only be understood as a developing totality, and that only a total subject can so understand it, namely the proletariat as a class. Revolution is the stage in this process by which the proletariat transcends its alienated state and becomes both the subject and object of history. ${ }^{25}$ This kind of Hegelian Marxism was criticised both by the Frankfurt school of Critical Theory and by Louis Althusser (1918-1990). Althusser saw himself as returning to an authentically Marxist philosophy. His abiding question was in what precisely this consists. The answer, he thought, could not be found by simply reading Marxist philosophy out of Marx. This was firstly because Marx had laid down only the cornerstones of the science of historical materialism, and secondly because his early works were written in terms of the ideology of humanism. ${ }^{26}$

\footnotetext{
${ }^{33}$ Marx, Selected Writings p. 417.

${ }^{24}$ See Alex Callinicos, Marxism and Philosophy (Oxford and New York: Oxford University Press, 1983) pp. 61-95.

${ }^{25}$ See David McLellan, Marxism After Marx: An Introduction (London: Macmillan, 1979) pp. 157-164.

${ }^{26}$ Louis Althusser, For Marx, tr. Ben Brewster (London: NLB, 1969) pp. 30-31.
} 
This is the first premise of Althusser's Marxism, that Marx's early humanist works are not authentically Marxist. Moreover, even in his later works, ideological concepts and theoretical weaknesses still survive. In order to specify the nature of Marxist science, according to Althusser, it is necessary to read Marx critically.

In Reading Capital (1965), Althusser finds the example, indeed the discovery, of this kind of reading in Marx's Capital. The readings of Smith, Ricardo and others that Marx offers there, Althusser writes, "involve two radically different reading principles'. ${ }^{27}$ They could be called 'double' readings. On one hand, Marx reads previous economists' discourse through his own discourse, balancing what Smith (for example) saw and what he did not see. Although certain facts were potentially obvious, Smith simply failed to see them, and Marx points them out. On the other hand, Marx's reading often concludes that 'what classical political economy does not see is not what it does not see, it is what it sees, ${ }^{28}$ Smith, on this reading, has not simply failed to see a certain socio-economic fact but, having seen it, he has not understood it. As Althusser writes, 'the oversight no longer concerns the object...but the sight itself ${ }^{29}$ In order to explain this integral relation of vision and non-vision, Althusser refers us to one of Marx's readings of classical economy concerning the value of labour. Marx writes:

The result the analysis led to... was not a resolution of the problem as it emerged at the beginning, but a complete change in the terms of the problem.

He points out that the classical text is silent about the very question it has asked. It answers the question (correctly enough) of the value of labour-power, but it

\footnotetext{
${ }^{27}$ Louis Althusser and Étienne Balibar. Reading Capital, tr. Ben Brewster (London: Verso, 1970) p. 18.

${ }_{28}$ Ibid. p. 121.

${ }^{29}$ Ibid.
} 
presents this answer as if it were the answer to the question of the value of labour, which it is not. ${ }^{30}$ Without knowing it, political economy has produced a new question. Marx's reading has brought out that what political economy has missed is not a pre-existent object but an object which it has itself produced in the process of its inquiry. This is the relation of sight and oversight in Marx's reading, and it leads Althusser to conclude:

We must completely reorganise the idea we have of knowledge, we must abandon the mirror myths of immediate vision... and conceive knowledge as a production. ${ }^{31}$

Marx's reading leads to the emergence of what Althusser calls a new 'problematic'. By this he means a conceptual system in which problems can be raised, 'the system of questions commanding the answers given' by a discourse. ${ }^{32}$ A problematic is

the horizon of a definite theoretical structure... which constitutes...the absolute determinations of the forms in which all problems must be posed $^{33}$

Marx has perceived that a new object (labour-power), which is invisible in the problematic of the existing theory (political economy), is overlooked by that theory. The object is not outside the field of vision of the theory; it is right in front of its eyes, as it were. It is an object that cannot be registered in the terms of the theory's problematic. Political economy can no more see labour-power than one could see a sound. In order describe this object, an entirely new set of terms is necessary. Marx's 'informed gaze' has hypothesised this new set of terms, in what Althusser calls a 'symptomatic reading'. ${ }^{34}$ By this he means that

\footnotetext{
${ }^{30}$ For Marx's distinction between labour and labour-power see Capital Vol. I, Part II, Chapter V, in Karl Marx and Friedrich Engels, Collected Works Vol. 35 (London: Lawrence and Wishart. 1996) pp. 166-177.

${ }^{31}$ Althusser and Balibar, op. cit. p. 24.

${ }^{32}$ Althusser, For Marx p. 67.

${ }^{33}$ Althusser and Balibar, Reading Capital p. 25.

${ }^{34}$ Ibid. p. 28.
} 
Marx managed to read the illegible in Smith, by measuring the problematic initially visible in his writings against the invisible problematic contained in the paradox of an answer that does not correspond to any question posed. ${ }^{35}$

Just as Freud detected the unconscious determinants of a symptom in the symptom itself, so Marx detected the problematic of which his object-text was unconscious in the lacunae of its own problematic. Althusser calls this kind of analysis an 'epistemological break'.

He argues that this kind of break begins in Marx's work in 1845, when, in The German Ideology, he abandons the humanist view in which history and politics are based on an 'essence of man', or human nature. In For Marx (1965), Althusser argues that in 1845 Marx broke from his early humanism and opened up the new problematic of historical materialism. In this view, history and politics are based on the concepts of social formation, forces and relations of production, superstructure and final determination by the economy. ${ }^{36}$ Marx replaces his previously central concepts of the subject and of essence with a 'theory of the different specific levels of human practice'. ${ }^{37}$ The subject of history is no longer the individual but a society. These societies do not have essences (as in Hegel's thought), but are determined by a specific complexity. A social formation is made up of a series of distinct levels, the economic, the political, the ideological and the scientific levels, each of which constitutes a 'practice'. By a practice Althusser means

any process of transformation of a determinate given raw material into a determinate product, a transformation effected by a determinate human labour, using determinate means (of 'production'). ${ }^{38}$

\footnotetext{
35 Ibid.

${ }^{36}$ Althusser. For Marx p. 227.

${ }^{37}$ Ibid. p. 229.

${ }^{38}$ Ibid. p. 167.
} 
The social formation, which is the 'subject' of history, is thus a complex totality of relatively autonomous but mutually effective processes of production. For Althusser, establishing these concepts as a framework within which to ask questions was Marx's 'scientific discovery'. 39

This discovery means that the specificity of Marxist philosophy is the conception of knowledge as the production of its object. Althusser calls this knowledge 'science', in opposition to the empiricist use of the term to denote the vision of pre-existent objects. A science arises from an ideology, of which it is the science. In 'Marxism and Humanism' (1963) Althusser defines ideology as a system of representations that imposes a structure on most people, 'not at all as a form of consciousness, but as an object of their 'world' - as their 'world' itself ${ }^{40}$ Ideology is the 'lived' relationship between people and the world, that is, people's fictive representation to themselves of their real relation to the social formation. This representation Althusser calls 'imaginary', by which he means that it expresses some kind of will, or reason to invest in the misrepresentation. In 'Ideology and Ideological State Apparatuses' (1969), he emphasises that the essence of ideology is that it "hails or interpellates individuals as subjects' ${ }^{41}$ It is a specific kind of misrepresentation of individuals' relation to the reality of the social formation, according to which they are autonomous subjects, stable, complete and the origin of their thoughts and actions, whereas in fact they are elements of the complex totality of the sum of social practices. He also emphasises the role of national institutions in the reproduction of ideological

\footnotetext{
${ }^{39}$ Ibid. p. 227.

${ }^{40}$ Ibid. p. 233.

${ }^{41}$ Louis Althusser, Lenin and Philosophy and Other Essays, tr. Ben Brewster (London: NLB. 1971) p. 160.
} 
formations. ${ }^{42}$ In his 'Letter on Art' (1966), Althusser sees the cognitive function of art to be neither scientific nor ideological, but as it were midway between the two. He writes, 'I do not rank real art among the ideologies... The peculiarity of art is to "make us see"... something which alludes to reality". ${ }^{43}$ A novel, for example, cannot give us a scientific knowledge of reality. It cannot describe the contradictory relation to reality of the ideology in which it is written. Nevertheless, it can make us 'see' that ideology. For Althusser, although it produces no scientific knowledge of a given ideology, art can nevertheless represent such an ideology as a lived experience.

\section{Pierre Macherey}

In his 'Letter on Art', Althusser wrote that in order to answer the question of art's relation to knowledge it was necessary to produce a scientific knowledge of art. $^{44}$ His student Pierre Macherey attempts such a production in his book $A$ Theory of Literary Production (1966). He begins by asserting with Althusser that ${ }^{\mathrm{C}} \mathrm{knowledge}$ is not the discovery of a latent meaning, forgotten or concealed. It is something newly raised up, an addition to the reality from which it begins' ${ }^{45}$ Literary criticism, therefore, must have an object that is a product of its activity. Macherey writes, 'Literary criticism is neither the imitation nor the facsimile of its objects; it maintains a certain separation or distance between [its] knowledge and its object' ${ }^{46}$ It is a discourse of another order than its object, literature, and

\footnotetext{
${ }^{42}$ Ibid. pp. 136-160.

${ }^{43}$ Tbid. pp. 203-204

44 Ibid. p. 206.

${ }^{45}$ Pierre Macherey, 4 Theory of Literary Production, tr. Geoffrey Wall (London and New York: Routledge, 1978) p. 6.

${ }^{46}$ Ibid. p. 7.
} 
the distance between the two allows the one to produce a knowledge of the other. In order for criticism to do this, Macherey writes, it must reject a series of fallacies. Firstly, it must reject the 'empiricist fallacy', which treats the work as 'factually given, spontaneously isolated for inspection'. ${ }^{47}$ In this kind of criticism, the literary work is treated as a pre-existent object, which criticism simply describes, tracing the structure of its composition and effect. Viewed this way, Macherey writes, the literary work can only be consumed, or 'move out from the provisional container of the book into the minds of possible readers' ${ }^{48}$ No knowledge is produced. The second error to avoid, he continues, is the 'normative fallacy', which judges a work by the standard of a kind of ideal model of itself. This type of criticism treats the work as if it 'should be other than it is; its only reality is its relationship to the model which was the very condition of its elaboration' ${ }^{49}$ It shifts the empirical fallacy (that the object of knowledge precedes its activity) to the ideal plane of the work 'as it ought to be'. The 'interpretive' fallacy, Macherey continues, replaces the work not with its ideal form but with its 'meaning'. 'It presupposes the active presence of a single meaning around which the work is diversely articulated" ${ }^{50}$ It is a 'purifying repetition', which repeats the essence of the work without its literary clothing. ${ }^{51}$

To be a science in Althusser's sense, or to produce its cognitive object, Macherey writes that criticism 'must go beyond the work and explain it, must say what it does not and could not say, ${ }^{52}$ This means that:

\footnotetext{
${ }^{47}$ Ibid. p. 13.

${ }^{48}$ Ibid.

${ }^{49}$ Ibid. p. 17.

${ }^{50}$ Ibid. p. 76.

${ }^{51}$ Ibid.

52 Ibid. p. 77.
} 
the postulated unity of the work which...has always haunted the enterprise of criticism, must now be denounced: the work is not created by an intention... it is produced under certain conditions. ${ }^{53}$

Rather than taking a literary work to be a given object, perhaps with an ideal form and an essence, Macherey proposes to treat it as disparate and contradictory. He stresses the 'determinate insufficiency' by which 'the book is not the extension of a meaning; it is generated from the incompatibility of several meanings' ${ }^{54}$ This incompatibility of meanings 'reveals the inscription of an otherness in the work, through which it maintains a relationship with that which it is not, that which happens at its margins ${ }^{35}$ This is the new object produced by the science of criticism, as Macherey conceives it, the relation of a text to what it does not say. He writes in his essay on structuralism, 'The work exists above all by its determinate absences, by what it does not say, in its relation to what it is not ${ }^{56}$ The relation of a text to its silences, for Macherey, is an index of the text's conditions of production. A work is produced within a specific ideological formation, and that ideology provides both the raw materials and the methods for its production. The text's silences are not accidental, but are the specific result of the nature of the ideology from which the text is produced. The relation between the text's utterances and its silences is determined by the ideology of which the text is a product. More precisely, they are determined by the contradictions within that ideology. When thought through or pressed to its logical conclusions, it is clear that an ideology does not accurately represent reality. For Macherey, a literary work displays this in its internal silences and structural conflicts. The work accurately represents an ideology as an apparently

\footnotetext{
${ }^{53}$ Ibid. p. 78.

${ }_{54}$ Ibid. pp. 79-80.

${ }^{55}$ Ibid. p. 80.

${ }^{56}$ Ibid. p. 154.
} 
unified or coherent discourse that is on closer inspection full of disparities and incoherence.

In the essay co-authored with Étienne Balibar, 'On Literature as an Ideological Form: Some Marxist Hypotheses (1974), Macherey considers the position of literature within what Althusser had called Ideological State Apparatuses. Whereas Macherey's previous work had focused on the literary text's production of ideology, Macherey and Balibar now consider literature as an ideological practice in itself. They analyse literature as a concept, arguing that it denotes a specific linguistic practice, inserted in the educational apparatus, which contributes to the reproduction of bourgeois ideology. The French educational system is divided into two types of school, 'primary-vocational' [primaireprofessionel] and 'secondary-higher' [secondaire-superieur]. In these schools, 'basic French' [français élémentaire] and 'literary French' [français littéraire] are taught respectively. ${ }^{57}$ 'Literary' French is constituted by this educational system as a special kind of language written in the common language. The concept of a language at once common and basic is a product of bourgeois ideology. Just as bourgeois ideology cloaks a system of privilege in an appearance of equality, so some speak a 'better' language, though all speak the same language. Literary language dramatises the contradiction in this ideology, since it is a special kind of language written within the common language. The education system is based on the same ideological contradiction: education for all, but better for some than for others. For Macherey and Balibar, the concept of literature and the education system mutually reinforce each other as means of reproducing this bourgeois ideology. They analyse the ways in which literary

\footnotetext{
${ }^{57}$ Terry Eagleton and Drew Milne. eds., Marxist Literary Theory: A Reader (Oxford and Cambridge, MA: Blackwell, 1996) p. 281.
} 
texts constrain individuals to treat them as 'literature'. Those uneducated in literary French find in it 'the confirmation of their inferiority', that their 'basic' discourse is "inadequate for the expression of complex ideas and feelings' 58 Macherey and Balibar conclude, "The literary text is the agent for the reproduction of ideology in its ensemble ${ }^{59}$

\section{Terry Eagleton}

Macherey's Althusserian theory of literary criticism as the production of knowledge of the text's relation to ideology was taken up and developed in the early work of the Oxford critic Terry Eagleton (b. 1943), who played a significant role in making continental literary theory familiar in the British academy during the 1970s. In his first theoretical work Criticism and Ideology (1976), Eagleton develops Macherey's project of describing the cognitive function of literary criticism in Althusserian terms. Eagleton writes that if criticism is to be scientific, it must 'show the text as it cannot know itself,... manifest those conditions of making... about which it is necessarily silent ${ }^{3}{ }^{60}$ He elaborates a series of categories by which a materialist criticism could produce this cognitive object. Firstly, it could attend to the 'general mode of production', that is, the sum of a society's productive forces and relations, in which one is normally dominant. Secondly, it could attend to the 'literary mode of production', which refers to the complex of ways in which literature is produced in a given society, of which one again will normally be dominant.

\footnotetext{
58 Ibid.

${ }^{59}$ Ibid. p. 292.

${ }^{60}$ Terry Eagleton, Criticism and Ideology: A Study in Marxist Literary Theory (London and New York: Verso. 1976) p. 43.
} 
Thirdly, it should analyse 'general ideology', which Eagleton defines as the set of discourses by which individuals' lived relations to social reality are distorted in order to perpetuate the dominant class-relations. Fourthly it should take account of 'authorial ideology', that is, an author's specific position vis-à-vis general ideology, and fifthly 'aesthetic ideology', that is, the subset of general ideology that deals with literary values, devices, critical norms and methods, the meaning of aesthetic experience and so on. ${ }^{6 !}$ A given literary text, Eagleton writes, can be seen as the 'product of a specific overdetermined conjuncture' of these elements. ${ }^{62}$

Following Macherey, Eagleton writes that the text produces ideology, that is, transforms its raw materials into a new object incommensurate with those materials. ${ }^{63}$ This production "so constitutes [an] ideology as to reveal something of its relations to history'. ${ }^{64}$ Eagleton conceives ideology as a production of historical reality, and so calls a text 'ideology to the second power' ${ }^{65}$ The text is a product of a product. Its immediate object or raw material is not historical reality but the ideological production of that reality. Reality is present in the text, for Eagleton, through its distorted presence in ideology. 'History... 'enters' the text...but it enters it precisely as ideology, as a presence determined and distorted by its measurable absences' ${ }^{66}$ As Eagleton puts it, 'The imaginary London of Bleak House... signifies, not "Victorian England" as such, but certain of Victorian England's ways of signifying itself ${ }^{67}$ The presence of history in the text is thus apparent only to criticism. Criticism can see in the text's production

\footnotetext{
${ }^{61}$ Ibid. pp. 45, 58, 60 .

62 Ibid. p. 63.

63 Ibid. p. 68.

64 Ibid. p. 69.

${ }^{65}$ Ibid. p. 70.

${ }^{66}$ Ibid. p. 72.
} 
of ideology something of the relation of that ideology to the real history of which it is a production. Eagleton writes, 'The text, through its formal devices, establishes a transformative relation between itself and ideology which allows us to perceive the usually concealed contours of the ideology from which it emerges'. ${ }^{68} \mathrm{He}$ criticises Althusser's and Macherey's formulations of this position insofar as they do not make clear that there is an aesthetic ideology as well as the ideology which constitutes the text's raw material. ${ }^{69}$ That is to say that the forms by which the text produces ideology are themselves ideologically determined. Some literary forms and devices are particularly susceptible to the representation of certain ideological messages, such as narrative to an ideology of individual progress. Eagleton writes, "The form of the ideological content... has a generally determining effect on the form of the text' ${ }^{70}$ Criticism, for Eagleton, must study the mutual interaction of ideology and aesthetic form in the text. This interaction appears as a process of conflicts produced, resolved and reproduced in the text. ${ }^{71}$ Eagleton concludes:

In yielding up to criticism the ideologically determined conventionality of its modes of constructing sense, the text at the same time obliquely illuminates the relation of that ideology to real history. ${ }^{72}$

Eagleton attempts to elaborate a Marxist account of aesthetic value, that is, of the apparently qualitative distinction between literary works. Thinking of Marx's analyses of value in Capital, he writes that value is always transitive or

\footnotetext{
${ }^{67}$ Ibid. p. 77.

${ }^{68}$ Ibid. p. 82.

${ }^{69}$ Ibid. p. 84

${ }^{70}$ Ibid. p. 85. James H. Kavanagh rightly points out that, in this kind of formulation. Eagleton 'resurrects [the] form-content problematic... extending rather than superseding Macherey's argument'. 'Marxism's Althusser: Toward a Politics of Literary Theory', Diacritics 12 (1982) p. 40 .

${ }^{\prime 1}$ Eagleton. op. cit. pp. 88-89.

${ }^{72}$ Ibid. p. 101.
} 
relational, that it is, in short, 'exchange-value'. ${ }^{73}$ Literary value is produced, Eagleton writes, in the consumptional act of reading. He asserts, 'The literary text is always the text-for-ideology, selected, deemed readable and deciphered by certain ideologically governed conventions of critical receptivity,${ }^{74} \mathrm{He}$ writes that the text 'presses its own modes of producibility upon the recipient'. ${ }^{75}$ By this he means that a text offers itself to a series of possible readings determined by the reader's specific insertion into an ideological formation. The value-relation, for Eagleton, lies in the relation between the text's production of an ideology and the reader's position within an ideology. The aesthetic constitutes the mode by which the work produces ideology, and in doing so, makes visible ideology's silences with regard to real history. For Eagleton, the perceptibility of an ideology's relation to reality in the work to a reader is the locus of its value. ${ }^{76} \mathrm{~A}$ literary work, that is, is valuable according to the clarity with which it presents the relation of the ideology it produces to the history of which that ideology is a production.

Eagleton was taken to task by Marxist critics for his attempt to defend the canon of literature whose value his opponents saw as determined ultimately by bourgeois criteria. He himself later noted the 'residual academicism' of the work, and in later work, such as The Function of Criticism (1984), was more concerned with 'relevance of cultural studies to revolutionary political practice'. ${ }^{77}$ In The Ideology of the Aesthetic (1990), he analyses the history of aesthetic thought in relation to its social and political determinants and

\footnotetext{
${ }^{73}$ Ibid. p. 167. See Capital Vol. I, Part I, Chapter I, Section 3, in Marx and Engels, Collected Works Vol. 35 pp. 57-79.

${ }^{74}$ Ibid.

${ }^{75}$ Ibid.

${ }^{76}$ Ibid. p. 178.
} 
consequences. He argues that the aesthetic is an 'eminently contradictory phenomenon' with respect to its determination by the class-struggle. ${ }^{78}$ On one hand the concept is essentially involved with the dominant ideology of modern class society, contributing to its reproduction. On the other, it is both a challenge and an alternative to that bourgeois ideology. Eagleton writes:

The aesthetic is at once...the very secret prototype of human subjectivity in early capitalist society, and a vision of human energies as radical ends in themselves...If it offers a generous utopian image of reconciliation between men and women at present divided from one another, it also blocks and mystifies the real political movement towards such historical community. ${ }^{79}$

The concept of the aesthetic originates in Alexander Baumgarten's Aesthetica (1750), where aesthetics is defined as an inferior analogue of logic at the level of the senses. It respects the particularity of sensible entities whilst ordering them as reason orders conceptual data. Eagleton relates this definition to the Enlightenment ideology of the subject. In Rousseau's thought, the ideal citizen 'retains his unique individuality, but... in the form of a disinterested commitment to a common well-being' ${ }^{80}$ This fusion of general and particular, Eagleton writes, 'resembles the very form of the aesthetic artefact', in which each autonomous part embodies the law of the whole. ${ }^{81}$ This means that the concept of the aesthetic can be seen as an emancipatory force. The aesthetic object displays the individuality of each of its elements at the same as each embodies the law of the whole, and so can be seen to represent a 'community of subjects...each safeguarded in its unique particularity while bound at the same

\footnotetext{
${ }^{77}$ James H. Kavanagh and Thomas E. Lewis, 'Interview: Terry Eagleton', Diacritics 12 (1982) p. 54.

${ }_{78}$ Terry Eagleton. The Ideology of the Aesthetic (Oxford: Blackwell. 1990) p. 3.

${ }^{79}$ Ibid. p. 9.

${ }^{80}$ Ibid. p. 25.

${ }^{81}$ Ibid.
} 
time into social harmony'. ${ }^{82}$ On the other hand, the aesthetic can function as a means of 'inserting social power more deeply into the bodies of those it subjugates'. Aesthetics applies the concept of law to the domain of sensible objects, where it had previously had no place. This can be seen as a contribution to an ideology that legitimates the subjection of material human existence to a totalising law. ${ }^{83}$ Eagleton traces the dual political function of the aesthetic from the Enlightenment through Marxist thought to postmodern theory. The latter, for Eagleton, represents on one hand 'the latest iconoclastic upsurge of the avant garde', confounding hierarchical thought and representation, and refusing the closure of ideology. On the other hand, it perpetuates late capitalism's 'consumerist hedonism and philistine anti-historicism', abandoning the

revolutionary concepts of truth, commitment and history. ${ }^{84}$ For Eagleton, this contradiction is a result of that between capitalist economy and bourgeois culture, the latter valuing individuality and distinction whilst the former effaces them in the commodity form. ${ }^{85}$

\section{Fredric Jameson}

Along with Eagleton, one of the most influential Marxist critics writing in English is Fredric Jameson (b. 1934), who teaches comparative literature at Duke University. Unlike Macherey and Eagleton, Jameson has always maintained an allegiance to Hegelian Marxism, with its dialectical categories and historical periodisation. His work could best be described as a synthesis of this

\footnotetext{
${ }^{82}$ Ibid. p. 28.

${ }^{83}$ Ibid.

${ }^{84}$ Ibid. p. 373.

${ }^{85}$ Ibid. pp. 372-377.
} 
tradition with Althusserian structuralism. In The Political Unconscious (1981), Jameson devises a narratology in these syncretic terms. He begins with the axiom that political interpretation is not one among many methods of literary criticism but 'the absolute horizon of all reading and all interpretation', ${ }^{86}$ For Jameson, only the Marxist philosophy of history can both give a proper account of the particularity of the cultural past and interpret its message in an alien present. ${ }^{87}$ It does so by means of the historical narrative of class-struggle. This narrative is not to be taken as the 'meaning' of a literary narrative, however. Jameson aims at a hermeneutics that asks not what a text means but how it works. He uses Althusser's concept of structural causality, that is, of the mutual effect of the various practices that constitute a social formation, to answer this question. Althusser distinguished this concept of causality from 'mechanical causality', the Newtonian model of cause and effect, and from 'expressive causality', the Hegelian model in which phenomena are caused by their essence, in order to describe a cause immanent in its effects. As Jameson writes, the concept of structural causality implies 'an absent cause... nowhere empirically present as an element' ${ }^{88}$ It is in this way, he asserts, that the historical narrative of class-struggle is related to individual literary narratives.

In Althusserian literary criticism, Jameson finds the kind of interpretation that interrogates works in terms of their conditions of possibility. For Jameson, the Marxist narrative provides the means fully to elaborate the semantic conditions of possibility of a work. ${ }^{89} \mathrm{He}$ proposes that the elements of a text can be seen in terms of their production in three 'semantic horizons', derived from the Marxist

\footnotetext{
${ }^{86}$ Fredric Jameson. The Political Unconscious: Narrative as a Socially Symbolic Act (London: Methuen. 1981) p. 17.

${ }^{87}$ Tbid. p. 19.

${ }^{88}$ Ibid.
} 
narrative of history. The first of these horizons is that of 'political history', or the sequence of events through time. In this horizon the text is seen, as by the earlier Macherey and Eagleton, as the formal resolution of social contradictions. ${ }^{90}$ The second horizon is that of 'society', conceived as the mutual opposition of antagonistic classes. In this horizon the object of interpretation is no longer the individual text but 'the great collective and class discourses of which a text is little more than an individual parole or utterance'. ${ }^{91}$ The text is seen as a unit of class-discourse, engaged in confrontation with an antagonistic class-discourse. Jameson calls this kind of semantic unit an 'ideologeme'. ${ }^{92}$ The third horizon is that of the 'mode of production', or form of social organisation. As these forms develop throughout history traces of past forms and anticipations of future forms coexist at any given moment. In this semantic horizon, the text is seen in terms of these forms of social organisation, as a product of the sign-systems they generate. Jameson calls the semantic object at this level of analysis the 'ideology of form, ${ }^{93}$

By interpreting a text in terms of its production at these semantic levels, the 'political unconscious' of a text, that is, its place in the history of the classstruggle, can be discovered, according to Jameson. The surface unity of the text, which 'represses' this unconscious narrative, he describes by means of the concept of the 'semiotic rectangle' of ideology. ${ }^{94}$ Jameson takes this concept from the structural semantics of A.J. Greimas (b. 1917). According to Greimas, the elementary structure of meaning can be represented in the form of a

\footnotetext{
${ }^{39}$ Ibid. p. 75 .

${ }^{90}$ Tbid. p. 77.

${ }^{91}$ Tbid. p. 76 .

${ }^{92}$ Ibid. p. 87.

${ }_{93}$ Tbid. p. 98 .

${ }^{94}$ Ioid. pp. 47-49, 82-83.
} 
rectangle, whose corners constitute (1) a term in a semiotic system, which can be understood only in reference to (2) its opposite and (3) its negative, which also has (4) an opposite. The term 'white', that is to say, takes on meaning by virtue of its contrast with its opposite 'black', its negative 'not-white', and the opposite of that negative 'not-black'. 95 For Jameson this semantic model describes the closed and static discourse of ideology. ${ }^{96}$ In a series of chapters on Balzac, Gissing and Conrad, he describes the repression of the political unconscious in a text by pointing out the inconsistencies in the structure of this ideological rectangle by which the text is superficially organised.

In Postmodernism, or, The Cultural Logic of Late Capitalism (1991), Jameson analyses postmodernism as the cultural effect of 'late' capitalism. He takes the concept of late capitalism from Ernest Mandel who, in his book of that name, argues that there have been three phases in the history of capital, corresponding to three phases in the history of technology. The first 'market' stage of capitalism (1840s-1890s), analysed by Marx, was characterised by steam power. It grew with the development of electric power into the 'monopoly' or 'imperialist' stage (1890s-1940s), analysed by Lenin. The 'multinational' or late stage, in which we find ourselves at present, began in the 1950 s with the production of electronic and nuclear power. ${ }^{97}$ For Jameson, it is characterised by the 'vision of a world capitalist system', in the form of multinational businesses, international division of labour, new forms of international banking, media interrelationship and computers. ${ }^{98}$ Postmodernism is the 'cultural dominant' of

\footnotetext{
${ }^{95}$ See A.J. Greimas and François Rastier, 'The Interaction of Semiotic Constraints', Yale French Studies 41 (1969) pp. 86-105.

96 Jameson, The Political Unconscious pp. $47+49$.

${ }^{97}$ Fredric Jameson, Postmodernism, or, The Cultural Logic of Late Capitalism (London and New York: Verso, 1991) p. 35.

${ }^{98}$ Ibid. p. xix.
} 
late capitalism, in which 'aesthetic production has become integrated into commodity production generally'.99 Its primary formal feature, Jameson writes, is 'a new kind of flatness or depthlessness' ${ }^{100}$ In the work of Andy Warhol, for example, even human subjects are explicitly commodified, existing primarily at the level of their own image. This commodified depthlessness is a characteristic not only of postmodern art and architecture, for Jameson, but also of postmodern theory, in which 'depth' models (for example the older existential contrast between authentic and inauthentic) are replaced with the 'multiple surfaces' of textuality, play, discourse, and so on. The characteristic form of postmodern culture Jameson calls 'pastiche', whose element is the 'identical copy for which no original has ever existed'. ${ }^{101}$ The essence of postmodern representation, for Jameson, is its new constitution of space. Postmodern space, he writes, is a 'hyperspace', in which the individual body can no longer 'organise its immediate surroundings perceptually...[or] map its positions in a mappable external world'. ${ }^{102}$ Postmodern architecture, fiction, video and so on, all describe spaces in which we cannot locate ourselves and whose topology defeats our perceptual abilities. Jameson sees this as a symbol of "the incapacity of our minds... to map the great global multinational and decentred communicational network in which we find ourselves caught as individual subjects'. ${ }^{103}$ The 'new global space' opened by the networks of multinational capital, he writes, is "the "moment of truth" of postmodernism'. $^{104}$ It is not an ideological representation but a historical reality of late capitalism.

\footnotetext{
99 Ibid. p. 4.

${ }^{100}$ Ibid. p. 9.

${ }^{101}$ Ibid. p. 18.

102 Ibid. p. 44.

103 Ibid.

${ }^{104}$ Ibid. p. 49.
} 
Though here and there tempted into denunciations of postmodernism's erosion of the possibility of collective action, Jameson writes that the proper mode of analysis of this historical formation is not ethical but dialectical, employing a method he describes as 'cognitive mapping'. ${ }^{105}$ This mode of criticism is intended

to enable a situational representation on the part of the individual subject to that vaster and properly unrepresentable totality which is the ensemble of society's structures as a whole. ${ }^{106}$

In late capitalism, Jameson writes, the conditions of production of a product, whether commodity or artefact (and in postmodern culture the distinction collapses) are felt to be 'beyond anything you can imagine'. ${ }^{107}$ He looks for an aesthetics in which multinational conditions of production of late capitalism are described, and its subject, insofar as it is possible, thus re-oriented. He writes, 'An aesthetic of cognitive mapping is in this sense an integral part of any socialist political project'. ${ }^{108}$ Postmodernism represents Jameson's initial attempt to broach this aesthetics, to see whether "by systematising something that is resolutely unsystematic... one couldn't outflank it and force a historical way at least of thinking about that ${ }^{2}{ }^{109}$

\section{(ii) Marxism and Christianity}

In order to assess the implications of these diverse theories for Christian literary theory, I will turn first to their conceptual foundations, and examine

\footnotetext{
${ }^{105}$ Ibid. p. 51.

${ }^{106}$ Ibid.

${ }^{107}$ Ibid. p. 46.

${ }^{108}$ Ibid. p. 416
} 
some of the relations between Marxism and Christianity. There is a wide spectrum of views on this question, since Marxism has meant different things in different situations. As David Lyon writes in his article 'Evaluating Marxism' (1982):

The perspective of the Soviet believer, working out his years in a labour camp for the crime of teaching his children from the Bible, is vastly different from the perspective of the Argentinian Christian who may see in Marxism an understanding the social injustices of his country and the possibility of their removal. ${ }^{110}$

The Western intellectual may have a third perspective on it as a valuable and revealing method of historical interpretation in contrast to more familiar rationalist or empirical models. In this section, I will examine some of the most significant mutual implications of Marxism and Christianity, and assess to what degree Christian criticism can and should use the methods prescribed by Marxist literary theories.

\section{Marx, Engels and Lenin on Religion}

Although Marx was born a Jew, his family converted to Protestantism. Both Marx and Engels were Christians in their youth, but by the time they came to write even their earliest works they had abandoned religion in its entirety, as a phenomenon outdated by science and philosophy. Marx's earliest view, expressed in his doctoral thesis (1841) and early journalism, was that it is an irrational submission to authority. In the foreword to his thesis, he identifies the task of philosophy with the words of Aeschylus' Prometheus. Marx writes:

\footnotetext{
${ }^{109}$ Ibid. p. 418.

${ }^{110}$ Alan Scarfe and Patrick Sookhdeo. Christianity and Marxism (Exeter: Paternoster, 1982) p. 127.
} 
Philosophy makes no secret of it. The confession of Prometheus - 'In simple words, I hate all gods' - is its own confession... against all heavenly and earthly gods who do not acknowledge human selfconsciousness as the highest divinity. ${ }^{111}$

The foreword opposes human self-determination to submission to the external authority of religion. During the middle 1840 s, German theological thought was being transformed by the critical work of Bruno Bauer, David Strauss and Ludwig Feuerbach. The last argued in his book The Essence of Christianity (1841) that God is a human projection, whom humans have imagined as a being possessed of attributes that are properly their own. Marx takes up a position influenced by Feuerbach in his Introduction to the Contribution to a Critique of Hegel's Philosophy of Right (1844). ${ }^{112} \mathrm{He}$ writes, 'Religion is the selfconsciousness and self-esteem of man who has either not yet found himself or has already lost himself again'. ${ }^{113} \mathrm{He}$ calls religion an inverted consciousness of the world, and 'the fantastic realisation of the human essence because the human essence has no true reality. ${ }^{114}$ Religion is both the expression of and the protest against real distress, which is what Marx means when he calls it the 'opium of the people'. He writes, 'To abolish religion as the illusory happiness of the people is to demand their real happiness'. ${ }^{115}$ Criticism of religion, for Marx, is in essence criticism of the social and economic situation from which it arises.

In Capital, Marx reaffirms the point that 'the religious world is but a reflex of the real world', and finds that Christianity, 'with its cultus of abstract man', is the most fitting reflex of a society based on commodity production. ${ }^{116}$ Once this

\footnotetext{
${ }^{111}$ Marx and Engels, On Religion (Moscow: Progress Publishers, 1975) pp. 14-15.

112 In Marxism and Christianity (London: Duckworth, 1968), Alisdair MacIntyre argues that Marxism is the 'historical successor' of Christianity because of its use of terms that, through Feuerbach and Hegel, derive from Christian theology.

${ }^{113}$ Marx and Engels, On Religion p. 38.

${ }^{114}$ Ibid.

115 Ibid.

${ }^{116}$ Ibid. p. 117.
} 
mode of production has been transformed in communist society, Marx writes, so will its religious reflection simply disappear. He writes, 'The religious reflex of the real world can...only then finally vanish, when the practical relations of everyday life offer to man none but perfectly intelligible and reasonable relations with regard to his fellowmen and nature'. ${ }^{117}$ Engels takes the same view. He writes in Anti-Dühring (1878) that when the socialist transformation of the mode of production occurs, so the 'alien force' of religion, the reflection of individual alienation from the means of production, will also vanish, 'for the simple reason that then there will be nothing left to reflect'. ${ }^{118}$ In Dialectics of Nature (1882), he asserts that natural science, despite the religion of many its practitioners, is increasingly proving the irretevance of God in explaining the material world. ${ }^{119}$

For Marx and Engels, religion is an illusory force, an ideology which impedes real change. As change occurs, religion, the expression of real misery, will cease to be necessary. Lenin's atheism is more militant. It is this perspective that has largely determined Communist party practice. Lenin writes, 'Every religious idea... is unutterable vileness,,.. "contagion" of the most abominable kind" ${ }^{120} \mathrm{He}$ calls it 'one of the most odious things on earth'. ${ }^{121}$ In his article 'The Attitude of the Worker's Party Towards Religion' (1909), he writes, 'Marxism is materialism. As such, it is relentlessly hostile to religion'. ${ }^{122}$ Marxism considers religions and churches, he writes, as instruments of bourgeois reaction that serve to defend exploitation and to befuddle the working class'. ${ }^{123}$ Lenin

\footnotetext{
17 Ibid. p. 118.

118 Tbid. p. 129.

119 Ibid. pp. 165-169.

120 V.I. Lenin. 'Letters to Maxim Gorky', Selected Works Vol. XI (London: Lawrence and Wishart. 1939) p. 675.

${ }^{121}$ V.I. Lenin, 'Leo Tolstoy as the Mirror of the Russian Revolution', Collected Works Vol. 15 (London: Lawrence and Wishart; Moscow: Foreign Languages Publishing House, 1963) p. 205

122 Lenin, Collected Works Vol. 15. p. 405.

123 Ibid. p. 403.
} 
redefines Marx's phrase 'the opium of the people'. Whereas Marx meant that religion was a kind of solace for the working class, for Lenin they are drugged with it by the external agency of the ruling class. In 'Socialism and Religion' (1905), he continues, 'Religion is a sort of spiritual booze in which the slaves of capital drown their human image, their demand for a life more or less worthy of man'. ${ }^{124}$ Like Marx, he considers that Marxism must combat religion at its social roots, namely 'the downtrodden condition of the working masses and their apparently complete helplessness in the face of the blind forces of capitalism'. ${ }^{125}$ Religion is an expression of the justified fear of the proletariat at the consequences of market fluctuation. Their party, Lenin writes, must fight its obfuscating veils at its roots, the rule of capital. ${ }^{126}$ The state should have no ties with the church, and religion, although in general a private matter, cannot be tolerated in socialist party members, since 'the ideological struggle is...the affair of the whole party, of the whole proletariat'. ${ }^{127}$ This was a significant sentiment in determining the anti-religious stance of the Soviet governments. Lenin's materialism, however, like that of Engels, means that he is not primarily concerned with atheism as a concept. Whilst the socialist party must educate the proletariat with anti-religious propaganda, he writes, its first principle is that the 'struggle... for the creation of a paradise on earth is more important...than unity of proletarian opinion ... about a paradise in heaven'. ${ }^{128}$

\footnotetext{
${ }^{124}$ V.I. Lenin Collected Works Vol. 10 pp. 82-83.

${ }^{125}$ Lenin, Collected Works Vol. 15 pp. $405-406$.

${ }_{127}^{126}$ Ibid. p. 406.

${ }^{127}$ Lenin, Collected Works Vol. 10 p. 86.
} 


\section{An Assessment of Marxist Atheism}

We should think carefully before we assert that these views make Marxism incompatible with Christian thought or practice. Marxism has many goals that appear to be in accord with those of Christianity, and this relationship needs to be accounted for before we reject Marxism as entirely useless to us because of its atheism.

We should distinguish at least two of the several meanings that can be assigned to the word 'Marxism'. Firstly there is Marx's thought and that of subsequent thinkers consciously indebted to his thought. Secondly there are the political and economic systems established in various countries in Marx's name, and the thought and practice that occur in those systems. To begin with Marxism in the first sense, we need to ask whether Marx says anything true about religion, and a historical answer must be that he does. As the Argentinian theologian José Míguez Bonino writes, in Christians and Marxists (1976):

A Christian, when confronted with this challenge [Marx's views on religion] should not hasten to refute it, but should rather ask himself how he can understand it, what he is being told about himself and his community. ${ }^{129}$

The answer to this question, historically speaking, is that the organised churches on the whole opposed movements for workers' rights during the Industrial Revolution. The Catholic Church in particular was smarting from the memory of the French Revolution, in which the church lost all its sources of income, tens of thousands of priests and bishops were killed or deported, and religious buildings and monuments were destroyed. After the revolution had ended, the Church

\footnotetext{
128 Ibid. p. 87.

129 José Miguez Bonino. Christians and Marxists: The Mutual Challenge to Revolution (Grand Rapids, MI: Eerdmans, 1976) p. 58.
} 
sought protection from the monarchy. "The very words "liberty", "equality" and "democracy", because of their association with the French revolution...carried threatening connotations ${ }^{2}$ to the church in the early nineteenth century. ${ }^{130}$ During the 1848 revolutions, Pope Pius IX's prime minister was assassinated and socialists were blamed for his death. The pope had to flee the Papal States, and on his return roundly condemned socialism in his 'Syllabus of Errors' of 1864. The German Protestant Church was similarly conservative, identifying itself with the Prussian state, with increased tenacity after the 1848 revolutions. Whilst individual Christians spoke out against capitalism and various societies for the relief of the poor were founded during the nineteenth century, the official churches allied themselves with the European states and remained distant from the conditions of the working class. The hierarchy came mainly from the aristocracy and the lower clergy from the peasant class, neither of whom had significant contact with the difficulties of the urban proletariat. ${ }^{131}$ On the whole, the Church stood against the working classes when they attempted to make demands for the improvement of their conditions. Neither is there any doubt of Max Weber's basic thesis that Protestantism and capitalism mutually stimulated and reinforced one another, nor of the relation between capitalist colonial expansion and the missionary enterprise. Marx's and Lenin's account of religion as an instrument of the oppressing classes, useless to the workers, was on the whole justified with regard to the churches of their time.

Nevertheless, we cannot accept the views of the Marxist authorities as a final diagnosis. They commit the fallacy of equating the socio-economic determinants

\footnotetext{
${ }^{130}$ Arthur F. McGovern, Marxism: An American Christian Perspective, (Maryknoll, NY: Orbis, 1980) p. 91

${ }^{131}$ Ibid. p. 93.
} 
of religious ideas with their truth-content. As Hans Küng writes, in Does God Exist? (1980):

From the undeniable influence of economic and social factors on religion and the idea of God, we can... draw no conclusion about the existence or non-existence of God. ${ }^{132}$

Because a religion offers comfort to the materially poor, it does not follow that it has no truth except for their poverty. On the contrary, it is possible that the comfort it offers is based on reality. Clearly this function of religion, and particularly of Christianity, which privileges poverty, can be abused, and has been. Nevertheless, the ideological abuse of a doctrine is not to be equated with its truth-content. With regard to Marx's early humanist critique, it should be pointed out that Christianity is also a humanism. Many have experienced Christianity as an enriching and dignifying system. Faith in the love of God and in the redeeming action of Christ can enable a person to act more courageously and to live more freely. Christianity properly understood is a call to full humanity, as contemporary theology is well aware. ${ }^{133}$ As for religion as an imaginary reflex of the real world, Christian morality is misunderstood as merely individualistic and other-worldly. On the contrary, it is profoundly committed to the real improvement of the real world. This has been most clearly brought out in recent decades by the 'liberation' theologians, to whose work we now turn.

\footnotetext{
${ }^{132}$ Hans Küng, Does God Exist? An Answer for Today, tr. Edward Quinn (London: Collins, 1980) p. 245.

${ }^{133}$ See 'Being Christian as Being Radically Human', in Hans Küng On Being a Christian, tr. Edward Quinn (London: Collins, 1978) pp. 504-602.
} 


\section{Liberation Theology}

An awareness of the Marxist critique of religion should create a greater understanding by Christians of their theology and practice, whose purpose is greater fidelity to the will of God. The Biblical witness strongly and repeatedly insists on the establishment of just social relations, and of the divine imperative to effect these relations when they are absent. The imperative of changing unjust social relations did not begin with Marx, but has been a concern of Christian ethics since its inception. This is the argument of Mexican theologian Jose Porfirio Miranda, in his book Marx and the Bible (1971). Western anti-Marxism, he argues, is a result not so much of Marx's inconsistencies, real as the latter are, but a rejection of 'all that in which Marx coincides with the Bible'. ${ }^{134}$

Miranda begins with some basic economic axioms, which he concludes with the proposition, 'Differentiating ownership could not and cannot come to be except by means of violence and spoliation'. ${ }^{135}$ If one thinks about ownership or wealth in the abstract, if one thinks about the essence of these things or what they are 'in themselves', clearly they are morally inoffensive. This is why Miranda calls Greek ontology, which assumes the primacy of being 'in itself' a 'philosophy of oppression'. ${ }^{136}$ For, according to Miranda, the 'essence' of differentiating ownership does not exist; it is an ideological construct masking the specific history of such ownership. Since the majority of the population would not freely assent to their own disempowerment by the accumulation of capital in the hands of the minority, it is clear that they entered into contracts

\footnotetext{
${ }^{134}$ José Porfirio Miranda Marx and the Bible: A Critique of the Philosophy of Oppression, tr. John Eagleson (Maryknoll, NY: Orbis, 1974) p. 252.

${ }^{135}$ Ibid. p. 13.
} 
with this effect either because they had no choice or because ideology made them unaware of other possibilities. ${ }^{137}$ Miranda writes that this view is the Biblical view. The word translated by 'almsgiving' in many passages, sedakah, is the Hebrew word for 'justice'. ${ }^{138}$ This is because 'almsgiving for the original Bible was a restitution that someone makes for something that is not his'. ${ }^{139}$ The Biblical concept of justice, in Miranda's exegesis, is concerned with the elimination of unjust social relations, particularly as represented by differentiating ownership, which makes some rich and some poor within the same society. The Hebrew verb saphat, 'to judge', does not primarily have our sense of a neutral or disinterested opinion of an object, he points out, but rather one of restoring justice to someone who is in some way deprived of it. ${ }^{140} \mathrm{He}$ draws this conclusion from a study of Septuagint translations of the root, a series of texts in which the word clearly makes no sense unless so interpreted (e.g. Ps. $10: 18,72: 4)$ and with reference to the 'judges' (sophetim) of Israel in the book of that name. ${ }^{141}$ The latter are not once represented exercising a juridical function, but as defenders from the oppression of invading peoples. The gospel passages against riches, Miranda continues, are a result of the same presupposition, that the wealth in question has necessarily been acquired by means of violence and injustice. The attribution by St. Luke to the Virgin Mary of the words, 'He has filled the hungry with good things and sent the rich away empty' (Lk. 1:53), would otherwise be incomprehensible. ${ }^{142}$ Miranda cites an array of patristic commentary to suggest that the Church Fathers before Constantine thought the

\footnotetext{
${ }^{136}$ See Emmanuel Levinas. Totality and Infinity: An Essay on Exteriority, tr. Alphonso Lingis (Pittsburgh: Duquesne University Press, 1969) p. 46.

${ }^{137}$ Miranda. Marx and the Bible p. 14.

138 Ibid. p. 15

139 Ibid.

${ }^{40}$ Ibid. p. 111.
} 
same. John Chrysostom, for example, writes of wealth, 'Its beginning and root have necessarily come out of injustice'. St. Jerome writes, 'All riches come from injustice... The rich person is either an unjust person or the heir of one'. ${ }^{143}$

Miranda focuses on the prevalence of the theme of 'interhuman justice' in the Old Testament in particular. He cites Jer. 22: 13-16:

"Woe to him who builds his palace by unrighteousness, his upper rooms by injustice,

Making his countrymen work for nothing, not paying them for their labour...

[Your father] did what was right and just, so all went well with him.

He defended the cause of the poor and needy, and so all went well.

Is that not what it means to know me?' declares the LORD.

Miranda expounds, 'To know Yahweh is to achieve justice for the poor' ${ }^{144}$ No cause-effect relationship is spoken of here, and Miranda writes that this is not because the Bible is unacquainted with those categories (when it means them, it uses them), but because they are not intended. ${ }^{145}$ Knowledge of Yahweh and interhuman justice are synonymous, in Miranda's exegesis, which conclusion he finds expressed also in Hosea, Isaiah and Habbakuk (Hos 4:1-2, 6:4-6, Is. 11:1-9, Hab. 2). Commenting on the same passage in A Theology of Liberation (1971), Gustavo Gutiérrez writes:

To know Yahweh, which in Biblical language is equivalent to saying to love Yahweh, is to establish just relations among persons, it is to recognise the rights of the poor. ${ }^{146}$

\footnotetext{
${ }^{141}$ Ibid. pp. 111-137.

${ }^{142}$ Ibid. p. 17.

143 J.-P. Migne, ed, Patrologia Graeca LXII 562-563; Patrologia Latina XXII 984.

${ }_{144}$ Miranda. Marx and the Bible p. 44.

${ }^{145}$ Ibid. p. 45.

${ }^{146}$ Gustavo Gutiérrez, A Theology of Liberation: History, Politics and Salvation, tr. Caridad Inda and Jolm Eagleson, (London: SCM, 1988) pp. 110-111.
} 
The reason for the anticultic tradition, or criticism of worship rites, in the Bible, is precisely related to this identification, Miranda continues. He cites Amos 5:2125 and Isaiah 1: 10-20.

'I have more than enough of burnt offerings, of rams and the fat of fattened animals;

I have no pleasure in the blood of bulls and lambs and goats...

Learn to do right!

Seek justice, encourage the oppressed.

Defend the cause of the fatherless

Plead the case of the widow.' (Is. $1: 11,17$ )

Miranda condemns the kind of apologetic exegesis of passages like these which holds that 'the prophets do not condemn cultus as such'. ${ }^{147}$ Amos and Isaiah are quite clearly not demanding justice in addition to cultus, nor recommending spiritual reform leading to a genuine religion. Their message is, 'I do not want cultus but rather interhuman justice'. ${ }^{148}$ Miranda writes, 'The question is not so much whether someone is seeking God or not but whether he is seeking him where God himself has said that he is' ${ }^{149}$

It seems to me that although Miranda may here and there slightly overstate his conclusions, he does so only slightly and errs in the Biblical direction. He asserts, for example, that God is knowable 'exclusively' in the need of the poor and accessible 'only' in the act of justice, which seems too absolute to incorporate the idea of prevenient grace and to militate against some of the value of prayer and of the experience of forgiveness. However, there can be no doubt that his exegesis is faithful to the spirit of the Old Testament, much more so than any kind of individualistic soteriology. It is quite clear that interhuman justice is the will of Yahweh, and that he can be said to remain unknown to those who do

\footnotetext{
${ }^{147}$ Miranda, Marx and the Bible p. 55.

${ }^{148}$ Ibid. p. 56.
} 
not practise it or allow injustice to continue. We could adduce many other Biblical passages in support of this view. In Lev. $25: 23$, the provenance of the Jubilee arrangements is that natural resources cannot be privately owned. Yahweh says, 'The land must not be sold permanently because the land is mine, and you are but...my tenants'. A systematic programme for a just society is outlined around the concept of the Jubilee in Lev. 25. In v. 37, Yahweh forbids lending money at interest or selling food at a profit to a poor member of the community. Dt. 24:14-15 forbids withholding his wages, which is condemned again in Jas. 5:4. I refer the reader also to Num. 35:8, Neh. 5, Ps. 52, Prov. $14: 31,22: 22-23$, Is. $5: 8$ and $11: 4$ for the identification of God with the poor and his condemnation of those in political and economic power who deny them justice. There is no doubt that Marx's diagnosis of financial exploitation by the powerful, who influence and control the legislature, of the majority of wageearning labourers, and his active call for an end both to this exploitation and the system which enables it, is anticipated and affirmed by the Bible.

In his book $A$ Theology of Liberation (1971), the Peruvian priest Gustavo Gutierrez sets out to elaborate a 'new way to do theology' in the context of the Latin American social and political situation, where the majority of exploited and oppressed peoples are Christians. ${ }^{150}$ The influence of Marxist thought, he writes, 'helps theology to perceive what its efforts...receive from the historical praxis of humankind, as well as what its own reflection might mean for the transformation of the world'. ${ }^{151}$ Development is not an adequate response to the Latin American situation, he writes; it is necessary rather to attack the roots of

\footnotetext{
149 Ibid. p. 57.

${ }^{150}$ Gutiérrez, A Theology of Liberation pp. 12, viv.
} 
underdevelopment with the process of the liberation of the exploited peoples of the Third World. This liberation he sees as the 'salvation of the whole man', encompassing both his spiritual and material qualities. ${ }^{152} \mathrm{He}$ finds this kind of salvation exemplified in the Biblical history of the Exodus. He writes:

The liberation of Israel is a political action. It is the breaking away from a situation of despoliation and misery and the beginning of a construction of a just and comradely society. ${ }^{153}$

Living in a situation of slavery (Ex. 1:1-14) and alienated labour (Ex. 5:6-14), Israel is called by Yahweh to liberation, from slavery and from the internalised consciousness of slavery that it effects in them (Ex. 14:11-12, 16:3), in a movement of self-determination Gutiérrez compares to creation. ${ }^{154}$ The salvation brought about in the Exodus, he writes, is the paradigm for Christian soteriology, conceived as 'the movement of human self-generation initiated by the work of creation'. ${ }^{155}$ Addressing the hermeneutic question as to whether temporal or spiritual redemption is the primary meaning of the Exodus and similar Old Testament passages concerning political liberation, Gutiérrez writes that such a dualistic question is 'foreign to the Biblical mentality'. ${ }^{156}$ For the latter, he goes on, salvation is a matter of total fulfilment, of which social and political liberation is a partial but real component. The struggle for a just society, Gutierrez writes, is 'a part of salvation history' ${ }^{157}$ In his opinion, the kingdom of peace announced by the prophets 'presupposes the defence of the rights of the poor, punishment of the oppressors, a life free from the fear of being enslaved by others'. He cites the eschatology of Isaiah $65: 21-22$ :

\footnotetext{
${ }^{151}$ Ibid. p. 8

I52 Ibid. p. 83.

${ }^{153}$ Ibid. p. 88.

${ }^{154}$ Ibid.

${ }^{155}$ Ibid. p. 91

${ }^{156}$ Ibid. p. 96

${ }^{157}$ Ibid. p. 97
} 
'They will build houses and dwell in them; they will plant vineyards and eat their fruit;

No longer will they build houses and others live in them, or plant and others eat...

my chosen ones will long enjoy the works of their hands.'

The struggle for a world in which these just relations obtain, for Gutiérrez, is a participation in the coming of the Kingdom, which, he writes, is 'incompatible' with social injustice. ${ }^{158}$

Whilst he emphasises that this theology is not to be taken as universally valid, but as the proper response to the specific socio-economic situation of contemporary Latin America, Gutiérrez' holistic soteriology seems faithful to the spirit of the Bible. He cannot be charged justly with replacing spiritual with political redemption nor with identifying the two, for he does neither. ${ }^{159} \mathrm{He}$ redresses the Western emphasis on individual and interior salvation in the genuinely Biblical direction of the salvation of the whole person. He reminds us that Christian theology cannot dismiss the Marxist programme as a merely thisworldly concern, since temporal liberation plays a real role in Biblical soteriology.

\section{Catholic Social Thought}

Having recognised that in many ways the Bible agrees with Marx on the evil of social injustice, on some of the ways in which it is carried out and on the moral imperative to eliminate it, we must add that the Marxist programme of action and the historical materialism from which it derives cannot be directly identified with

\footnotetext{
${ }^{158}$ Ibid.

159 This charge is made against certain liberation theologians by Joseph Cardinal Ratzinger, in the Sacred Congregation for the Doctrine of the Faith's 'Instruction on Certain Aspects of the
} 
Christian moral action. Though any non-Marxist reformism is denounced by Marxism as in principle involved with bourgeois dominance, a misguided attempt to improve a system that is rotten to the core, nevertheless if one does not believe with Lenin that truth is equivalent to proletarian consciousness, such a case is not in principle self-evident. Without wishing to deny that, in certain situations, revolutionary action may be the most pressing course for a Christian to pursue, we must nevertheless assert that the Marxist project cannot be identified in its totality with Christian 'praxis', and that the Marxist concept of revolution is not equivalent to Christian eschatology. Plotting this kind of middle course between the Biblical concept of justice and historical materialism as a world-view has been the characteristic effort of the 'social doctrine' of the Catholic magisterium.

This tradition of discussion of the conditions brought about by industrial capitalism, as well as the Marxist proposals for their remedy begins with Pope Leo XIII's encyclical Rerum Novarum (1891), commissioned after a series of bishops intervened on behalf of workers' movements. Leo condemns the 'inhumanity' and 'unbridled greed' of industrial employers, adding that a 'devouring usury' has increased the evil of dispossession for the majority. The process of production and trade, he writes, has resulted in a situation in which 'a very few... exceedingly rich men have laid a yoke almost of slavery on the unnumbered masses of non-owning workers' ${ }^{160}$ Although, like Marx, he begins with the fact of unequal distribution of wealth, Leo condemns the Marxist contention that the root of the problem is private property. His view is that Marx's proposed socialisation of property 'actually injures the workers' whom it vatican/libtheo.asc>. 
is intended to benefit. ${ }^{161} \mathrm{He}$ sees private property as a fact of natural law, according to which the product of labour should belong to the labourer. $\mathrm{He}$ writes, 'Would justice permit anyone to own and enjoy that upon which another has toiled? ${ }^{162}$ In this of course, he is in agreement with Marx, who writes in the Communist Manifesto that since private property is already done away with for nine-tenths of the population, the communists can hardly be reproached for proposing to take away something that most do not have. Both agree that the worker should enjoy the product of his labour; Leo finds that 'socialism' denies him even this just hope. On the contrary, it offers him a false hope. Leo writes:

If they promise the poor in their misery a life free from all sorrow and vexation..., they...perpetuate a fraud which will ultimately lead to evils greater than the present. ${ }^{163}$

In fact, he continues, the socialisation of property and its administration by the state would result simply in another form of slavery for citizens. He writes, "The equality conjured up by the Socialist imagination would, in reality, be nothing but uniform wretchedness and meanness for one and all, without distinction". ${ }^{164}$ The Catholic magisterium has continued to affirm that in practice communist societies often continue to violate the rights of those they came into being to protect.

Leo sets out a series of proposals for the situation of the workers, which include the employer's duty to pay a just wage, which will be 'not less than enough to support a worker who is thrifty and upright'. ${ }^{165}$ The pope adds, as we have seen Miranda do, that if a worker is compelled to accept less than this, even

\footnotetext{
${ }^{160}$ Leo XIII: Rerum Novartum, tr. N.C.W.C. (Boston: St. Paul, 1942) no. 6.

${ }^{161}$ Ibid. no. 8.

${ }^{162}$ Ibid. no. 16

${ }^{163}$ Tbid. no. 27

${ }^{164}$ Ibid. no. 22

${ }^{165}$ Ibid. no. 63.
} 
if he gives his consent to the contract, he is the victim of unjust force. Leo affirms and encourages the right of association.

In his apostolic letter Octagesimo Adveniens (1971), Pope Paul VI affirms the duty of Christians to take part in the political organisation of society. This is impossible, he writes, if they adhere to doctrinal systems which contradict their faith. The pope calls these systems 'ideologies', and asserts that a Christian can adhere neither to the Marxist nor to the liberal ideologies. This is the first time the popes mention Marxism by name, and Paul here objects to its 'atheistic materialism,...its dialectic of violence and...the way it absorbs individual freedom in the collectivity'. ${ }^{166} \mathrm{He}$ objects in the same paragraph to laissez-faire liberalism, 'which believes it exalts individual freedom by withdrawing from it every limitation, [and] by stimulating through exclusive seeking of interest and power'. ${ }^{167}$ Paul acknowledges that Marxism means different things to different people. He distinguishes the practice of class-struggle, single-party government in the name of the collective, historical materialism and a dialectical method of analysis that combines theory and practice. ${ }^{168}$ Although a Christian may legitimately accept one or some of these aspects of Marxism, Paul writes that they are 'intimately' and 'radically' interconnected, and that it is difficult to employ methods of Marxist analysis without logically committing oneself to its end result, totalitarianism. ${ }^{169}$ Liberalism, though, is no better an option, for Paul. He describes the latter as an ideology of efficiency and individualism which disguises its roots in 'an erroneous affirmation of the autonomy of the

\footnotetext{
${ }^{166}$ Paul VI, 'Octagesimo Adveniens', Michael Walsh and Brian Davies, eds. Proclaiming Justice and Peace: Documents from John XXIII to John Paul II (London: Collins, 1984) no. 26.

${ }^{167}$ Ibid.

168 Ibid. no. 33.

${ }^{169}$ Ibid. no. 34
} 
individual'. ${ }^{170}$ In short, the pope finds that 'bureaucratic socialism, technocratic capitalism and authoritarian democracy' alike are incapable of bringing about a just society, and he calls for 'utopian' thinking that will address the problem afresh.

Pope John Paul II has written three encyclicals on the 'social question', which contain the most carefully thought-out responses to Marxism in the magisterium. With a clarity of emphasis not found in his predecessors, John Paul's thought is centred on the dignity and rights of the human person, and it is from this perspective that he analyses Marxism. In his first encyclical Redemptor Hominis (1979), he writes that man is 'the primary and fundamental way for the church', and in Centesimus Annus (1991), he affirms that 'the person is the way of the church'. ${ }^{171}$ He introduces Laborem Exercens (1981), his encyclical 'On Human Work', with the assertion that 'the Church considers it her task...to call attention to the dignity and rights of those who work'. ${ }^{172}$ This seems to be the appropriate moral and Biblical standard by which to judge Marxism. Like Paul VI, John Paul considers both Marxism and capitalism inadequate systems for the fulfilment of human dignity and looks for a third way between them. In many things, the pope is in agreement with Marx. He looks for the kind of social analysis that works by "not concealing unjust structures but demanding that they be examined and transformed on a... universal scale' ${ }^{173} \mathrm{He}$ is aware that alienated labour is still a reality, writing that 'technology can cease to be man's ally and become almost his enemy, as when the mechanisation of work 'supplants' him' ${ }^{174}$ He condemns

\footnotetext{
${ }^{170}$ Ibid. no. 35.

171 John Paul II, Redemptor Hominis no. 14, <http://listerv.american.edu/catholic/church/ papal/jp.ii/ redeem.asc >; Centesimus Annus, tr. Vatican (Boston: St. Paul, 1991) no. 53.

${ }_{172}$ John Paul II, Laborem Exercens, tr. Vatican (Boston: St. Paul, 1981) no. 1.

${ }^{173}$ Ibid. no. 2.

${ }^{174}$ Ibid. no. 5.
} 
the commodification of work, in which 'man is treated as an instrument of production, whereas he... ought to be treated as the effective subject of work' ${ }^{175}$ This danger, he continues, is always present. He writes, 'The error of early capitalism can be repeated whenever man is...treated on the same level as the...material means of production'. ${ }^{176}$ Indeed the pope describes nineteenth century reactions to these abuses, in broad terms clearly encompassing Marxism, as 'a just social reaction', an altogether new view from the magisterium. Citing Dt. $24: 15$ and Jas. 5:4, the pope writes:

The reaction against the system of injustice and harm that cried to heaven for vengeance... in that period of rapid industrialisation was justified from the point of view of social morality. ${ }^{177}$

Nevertheless John Paul does not accept Marxism as a conceptually adequate remedy to the situation either of the nineteenth or of the twentieth centuries, and we must agree with this conclusion. Addressing the issue of the conflict between capital and labour, that is, the power of a minority of entrepreneurs and owners of the means of production over the majority of non-owning labourers, the pope rejects the Marxist theory and practice of class-struggle, as well as the collectivisation of the means of production towards which it struggles. The Marxist programme, in his view, results from a simply inadequate analysis of the problem. The first principle of such analysis, the pope writes, must be the 'priority of labour over capital', which is to recognise that everything available for the development of production and profit is the result of work. ${ }^{178}$ 'Everything contained in the concept of capital...is only a collection of things', John Paul asserts, and the axiological priority of the human subject, who works upon or

\footnotetext{
${ }^{175}$ Ibid. no. 7.

176 Ibid.

${ }^{177}$ Ibid. no. 8.

${ }^{178}$ Ibid. no. 12.
} 
produces these things, must be affirmed. ${ }^{179} \mathrm{~A}$ just labour-system, for John Paul, is one that overcomes the opposition between labour and capital by acknowledging the priority of the human worker. That is to say, it will fall neither into the inhumane errors of capitalism nor into the Marxist error of 'economism', by which the pope means the consideration of labour only from an economic perspective, and which results from the kind of materialism that 'totally reduces man to...the satisfaction of material needs'. ${ }^{180}$

Such a system, for John Paul, will reflect the fact that the right to private property is not 'absolute and untouchable'. On the contrary, the pope writes, 'the right to private property is subordinated to the right to common use, to the fact that goods are meant for everyone'. ${ }^{181}$ Not only is the strength of this emphasis new to the magisterium, but so also are John Paul's assertions about right ownership of the means of production. The only legitimate title to ownership of the means of production, he writes, whether private or public, is that they should 'serve labour', that is, make possible the universal destination of goods and the right to their common use. ${ }^{182}$ The pope thus calls for the 'socialisation' of property, by which he means joint ownership of certain of the means of production in accordance with these principles. ${ }^{183} \mathrm{He}$ affirms the necessity of 'a struggle against an economic system...understood as method of upholding the absolute predominance of capital', but writes that the Marxist concept of this struggle turns merely into state capitalism. ${ }^{184} \mathrm{He}$ calls for state intervention to achieve labour reform according to the twin principles of 'subsidiarity' and

\footnotetext{
179 Ibid.

${ }^{180}$ Ibid. no. 13. Centesimus Annus no. 19.

181 Laborem Exercens no. 14.

182 Ibid.

183 Ibid.

${ }^{184}$ Centesimus Annus no. 35.
} 
'solidarity'. By the first he means funding geared towards balanced economic growth and full employment, and by the second he means a system of legal limits to the autonomy of employers and ensuring support for the unemployed.

The fundamental error of Marxism, John Paul writes in Centesimus Annus (1991), is anthropological in character, by which it 'considers the individual person simply as an element, a molecule within the social organism". ${ }^{185}$ There is no doubt that he is right to say so. Marxist anthropology results in seeing the good of the individual as subordinate to the good of the whole socio-economic mechanism, and as something that can be realised without the individual's free choice. John Paul considers the historical abuses of the Leninist concept of the dictatorship of the proletariat, an executive ruling in the name of class-interest, in this context. The first principle at stake in this anthropology, John Paul writes, is that of theism. For the pope, the 'apex of [the individual's] humanity' is his 'response to the call of God contained in the being of things', by which he realises his 'transcendent dignity". ${ }^{186}$ The pope sees the collapse of Eastern European communism as a result ultimately of the denial of this vocation. He traces the failure of Communism in practice to the violation of workers' rights that it was supposed to protect, and writes that this paradox came about through a collectivist anthropology not properly representative of individual human dignity. 'It is not possible', the pope writes, 'to understand the human person on the basis of economics alone, nor... simply on the basis of class membership' ${ }^{187}$ Human alienation is not only material, for John Paul, which is why communism in practice 'does not do away with alienation but rather increases it'. ${ }^{188}$ A person

\footnotetext{
185 Ibid. no. 13.

186 Ibid.

187 Ibid. no. 24.

${ }^{188}$ Ibid. no. 41 .
} 
is fundamentally alienated, he writes, if he is not able to 'transcend himself', and a social form that prevents this, either in theory or in practice, will contribute to human alienation. $^{189}$

Whilst the Catholic magisterium has clearly undergone substantial refinements since the rather agrarian and patrician views of Leo XIII, its view is on the whole a balanced one, with much of which we should agree. Put simply, it amounts to the proposition that Marxism provides an accurate diagnosis of the injustice of social relations, but does not provide a useful cure for them. This seems to me to be true. In fact, we must recognise that Marxism functions more effectively as a series of questions rather than of answers. For example, Marxism asks, surely it is conceivable that society can be organised in a better way for its members than by their present mutual antagonism? We must reply, in my opinion, that it is both desirable and really conceivable. We must recognise work for it as a Christian moral imperative. But although Marxism asks the right questions, we must also recognise that it does not offer an adequate answer to them. It recognises neither the dignity of the individual human person, nor his or her capacity for selftranscendence, in which this dignity can be fully realised. Nor on the other hand does Marxism do justice to the internal conflict of the human psyche. Whilst Althusserian thought is indebted to the Freudian tradition, it tends to allegorise psychological conflict into social conflict at the expense of a useful individual psychology. We will discuss our concept of the relation between the spirit-flesh conflict and the ego-libido conflict in the next chapter, but for now we can note the following. Whether one uses Pauline or Freudian terms, the internal contradiction of the individual plays a part in the social injustice both of 
capitalist and of socialist societies that Marxism neglects to its conceptual and practical disadvantage.

What this means for our evaluation of Marxist literary theories is this. First, the atheism we may find implicitly or explicitly stated in Marxist literary theory need cause us no hesitation in using some of the latter's methods in practice. There is a great deal of justice in the Marxist critique of religion, and the Christian critic should respond to it as a useful challenge to his or her potential historical or conceptual complacency. The methods of ideology-critique to be found in Marxist criticism, even when applied to Christian institutions, sentiments or characters, have a valid place in Christian literary theory, and should be used where appropriate. If we understand criticism as a kind of knowledge, then critique even of the unjust functions of Christianity that can be discerned in a given text increases our knowledge. Second, we should take from the liberation theologians the principle that social critique, including ideologycritique, is an ethical imperative for Christian criticism. Insofar as Marxist theory elaborates methods for the description of unjust relations at work in a literary text and of the ideologies by which they are maintained, Christian literary can and should endorse them. Third, we must remember that despite all the validity of its moral critique, we differ from Marxism in our transcendental perspective. In terms of critical methodology, sociological analysis is not the last word for Christian literary theory. We have a different anthropology to Marxism, and as a result, we must be more concerned with the role of individuals in a literary work than Marxist criticism. Moreover, we will be concerned not only with the Marxist identification of utopian impulses but also with the individual's capacity for transcendence. 


\section{(iii) A Critique of Marxist Literary Theories}

Despite some of the lessons we can learn from Marxist literary theory, we should not take it as a critical orthodoxy. There are problems with individual theories and with the concept of Marxist literary theory itself, of which we should be aware before making a final judgement on its value. In this section, I will examine some of these problems, in order to show that Marxism should not be taken as a final authority in literary theory, and in order to further my assessment of the use that Christian literary theory can make of its methods.

\section{The Concept of Ideology}

A long-standing difficulty in Marxist theory is its means of establishing criteria for the difference between ideology and science. In the Althusserian formulation, a science is the science of an ideology, which knows that the ideology's representation of individuals' relation to reality is imaginary. The question we must ask is how one establishes the difference between a true and an imaginary representation of these relations. In an early definition, Althusser contrasted science and ideology by writing that in the latter 'the practico-social function is more important than the theoretical function'. ${ }^{190}$ It is a matter of 'lived' relations rather than of thinking through those relations. But Marxist theory has a profound social and practical function. How are we to know that this does not render it ideological, that is, an imaginary representation? Moreover, Marxism

${ }^{190}$ Althusser, For Marx p. 229. 
holds that many philosophies and conceptual formulations are ideological, although these are clearly intended to have a theoretical function.

We must recognise that Marxist conceptions of ideology range beyond the idea of false consciousness. There are two broad strains in the Marxist understanding of ideology. The wider sense of the term denotes any conjuncture between discourse and political interests. In this sense, socialism or feminism can be described as ideologies. The narrower sense, with which we have so far been concerned, identifies these interests with the dominant social power and its reproduction. ${ }^{191}$ In Ideology (1991), Terry Eagleton is concerned to rescue the concept of ideology from a definition by false consciousness, because of the problem of establishing the standard by which it is held to be false. In a discussion of the falsification of thought by social determinants, he writes:

The trouble with this formulation is that there is no thought which is not socially determined. So it must be a question of the kind of social determinants under consideration. ${ }^{192}$

This is true, but it is more a refinement of the problem than a solution to it. The question of the position from which these differing kinds of social determinant are evaluated remains. Eagleton's example is that 'a prisoner is more likely to recognise the oppressive nature of a particular juridical system than a judge' ${ }^{193}$ A prisoner and a judge may indeed hold different views on a judicial system, and there are many instances in which the prisoner's will be more accurate concerning the moral state of the system. But when Eagleton says that it is 'more likely' that this will the case, he does so by reference to a system of values whose social determination is not in question. He means that it is more likely that the prisoner will have the clearer view because judicial systems tend to serve

\footnotetext{
191 Terry Eagleton, Ideology: An Introduction (London and New York: Verso. 1991) p. 221.

${ }^{192}$ Ibid. p. 51.
} 
the oppressive interests of the bourgeoisie. The position from which he makes this evaluation is treated in practice as if free from determinants. A Marxist has determining causes for his Marxism as the bourgeois does for his liberalism. Why the Marxist's reasons should be considered the more valuable can only be explained in terms whose genesis is not held to affect their value. If Eagleton were to follow the logic of his rejection of false consciousness theories of ideology, he would have to acknowledge that there are different kinds of determinants of the value-systems by which different kinds of determinants of thought are judged more valuable, and so on ad infinitum. Whilst trying to dissociate ideology from a definition by false consciousness, Eagleton remains within the dichotomy of true and false consciousness. The question he attempted to avoid, that of the criteria by which the Marxist's own view is to be judged true, remains unanswered. Eagleton gives us no reason to believe in a qualitative difference between (socially determined) Marxist thought and (socially determined) non-Marxist thought.

The literary critics we have discussed often fall into the same polarisation as they use the category of ideology, privileging the position from which they use it. Macherey's Althusserian criticism conceives Marxist criticism to construe a new object, the relation of what the text says and does not say. However, the Marxist critic's description of what the text does not say, in this theory, has nothing of consequence that it does not say. The Marxist critic is held to be undeceived with regard to the identification of the ideology from which the text is produced. In his essay on Jules Verne, Macherey finds that the relation between Verne's text and its lacunae is determined by the contradictions in the

193 Ibid. 
nineteenth-century bourgeois ideology of the conquest of nature. What he does not say is how he knows that this is an ideology. We have to take it on his own authority that Macherey's text, as well as the Marxist and Althusserian texts through which he reads Verne, are themselves free from misrepresentation.

Eagleton highlights the problem as he differs from Macherey over what constitute the ideological elements in a literary text. He denies Macherey's assertion that texts are always internally fissured by the conflict of ideology with history. Eagleton writes:

It is not invariably true that a text is thrown into grievous internal disarray by its relation to ideology, or that such a relation consists simply in the text's forcing ideology up against the history it denies. ${ }^{194}$

He cites Pope's Essay on Man as an example, in which internal conflict is not a primary feature of the literary product. He calls Macherey's position 'dogmatic', and in doing so rightly points out the drift towards authoritarianism visible in the practice of ideology-critique. Macherey's criticism neither establishes how it knows an ideology to be an ideology, nor how it knows which elements in a text are determined by ideology. In both cases, the distinction is determined on the critic's own authority.

The lack of criteria by which knowledge is validated leads to a further problem in the use of the concept of ideology in Marxist criticism. It is often not accurately or convincingly established in practice of what a given ideological formation actually consists. In Criticism and Ideology, for example, Eagleton spends two pages describing 'bourgeois ideology in nineteenth century England' and a paragraph on the ideology of 'organicism'. Yet he structures the following fifty-seven pages of literary criticism in terms of this ideology. In The Ideology of the Aesthetic, he frequently spends only one or two paragraphs, often without 
precise historical references, outlining the conditions of a social and intellectual milieu in the broadest of terms. On that basis he proceeds to analyse a text in terms of that milieu. The result is that the criticism is full of unsubstantiated generalities. For example Eagleton writes:

Kant speaks up for a generous vision of a community of ends, finding in the freedom and autonomy of the aesthetic a prototype of human possibility equally at odds with feudal absolutism and possessive individualism. $^{195}$

The point is not that such statements like this are in principle untrue, but that large concepts like 'feudal absolutism' and 'possessive individualism' have not been shown to be of precise relevance to Kant's texts. It is paradoxical that Marxist critics, who have history so much on their side, in practice largely neglect to make adequate use of it. On the whole, Marxist literary criticism talks more about history than it actually practises it.

This criticism can be levelled at the work of Fredric Jameson. In a review of Postmodernism, Reed Way Dasenbrock points out that Jameson makes no effort at a concrete historical analysis of the Marxist states in the postmodern period, despite the 'global' claims of his theory. Nor does he deal with the Third World in any detail. Dasenbrock writes, 'Jameson's assertion of a period style of postmodernism is only possible as long as he walls out and misreads what is being produced by the postcolonial cultures of the world'. ${ }^{196}$ It is one thing to distinguish between true and false representations of the 'social totality', and quite another satisfactorily to produce a true one. In practice, it is by no means clear that Jameson has succeeded in the latter attempt, and if he has not, we must ask how he knows that the false representations are false. The same question

\footnotetext{
${ }^{194}$ Eagleton, Criticism and Ideology p. 93.

195 Eagleton, The Ideology of the Aesthetic p. 100.
} 
should be asked of his methodological terms in The Political Unconscious. Why are we to accept that texts are produced in the horizons of ideology, of classstruggle and of mode of production? The texts themselves that Jameson analyses do not bear this out with any clarity. ${ }^{197}$ The only reason we have to accept these terms as really representative of textual production within the process of history is an implicit appeal to the authority of the Marxist texts.

The conclusion we must draw from this is that there may exist such a thing as bourgeois ideology but that a Marxist science of it does not exist. In Marxism and Christianity (1983), Denys Turner offers a useful analogy, as he compares the relation of Marxist science with ideology to that of self-knowledge with selfdeception. He writes, "It has to be admitted that no one can ever be sure that he is not deceiving himself in some way at any time'. ${ }^{198}$ It is possible to increase my self-knowledge by becoming aware that I was deceived in the past over a certain point and am now undeceived over it. But ' $I$ cannot be sure that in some other way I am not deceiving myself now' ${ }^{199}$ We can know, that is, that ideology is a misrepresentation of reality but not that Marxism is an accurate representation. In his article 'Demystifying the Demystifiers' (1988), Oscar Kenshur makes a similar point. He condemns what he calls 'ideological essentialism', or the Marxist practice of linking an epistemological position with a political one. He takes issue with Michael Ryan's analysis of Hobbes in his book Marxism and Deconstruction (1984), where Ryan links Hobbes' rationalism with political

\footnotetext{
${ }^{196}$ Reed Way Dasenbrock, 'Fredric Jameson and the Dilemmas of Late Marxism', Raritan 11 (1992) p. 129.

${ }^{197}$ In 'Narrative and Ideology: A Critique of Fredric Jameson's The Political Unconscious', J.A. Berthoud argues that Jameson's methodology leads him to distort the plain sense of the texts he analyses. His analyses of Conrad, Berthoud clearly shows, work by wrenching passages of text out of their context both in the uarrative and in the author's thought as a whole. Jeremy Hawthon, ed., Narrative: From Malory to Motion Pictures (London: Edward Arnold, 1985) pp. 107-115.

${ }^{198}$ Denys Turner, Marxism and Christianity, Oxford: Blackwell, 1983 p. 121.
} 
absolutism. Kenshur points out that Hobbes himself is engaged in a structurally similar attempt to link the views on inspiration of his enemies the Puritans with their politics. Both Hobbes and Ryan claim that their opponents argue for an unjustified immediacy to knowledge, but Hobbes links this position with sedition and Ryan with oppression. Kenshur's justified conclusion is that epistemological positions can serve quite different political ends: appeals to reason or to intuition can be of use both to oppressed and to ruling social groups. This analysis reinforces our conclusion that whilst an ideological analysis may be valid in itself, it is not so as a result of the scientific position from which it is carried out.

The lack of a means of verifying Marxism's claim to be a science gives us a certain amount of freedom in the use of the concept of ideology. Whilst Christian literary theory can and must recognise the presence of dominant interests in a literary work, it is not committed thereby to Marxism as the truth distorted by those interests. In particular, we can reject Althusser's definition of humanism as an ideology, and of the individual as an effect of the social whole. We need not disagree that many aspects of an individual's life are determined by the mode of production, but neither need we accept with Althusser that he or she is entirely so determined. Christian criticism can point out the effects of bourgeois ideology in a work, without implying that Marxism is the position free of misrepresentation from which it does so. Nevertheless we should also remember that since ideology-critique implies no superiority in the position from which it is carried out, we can assume no superiority in our own position when we use it. We must avoid the temptation of assuming a moral or sociological freedom from the class-interests we may discover in the texts we analyse.

${ }^{199}$ Ibid. 


\section{Intra-Marxist Critique}

Because of the incommensurability of Marxism with any other first principles, most of the criticism of Marxist literary theory comes from within the Marxist community. Unless one has a prior allegiance to Marxism, the literary criticism that derives from it will seem unconvincing. Liberal and conservative critics have very little common ground from which to begin dialogue with Marxist criticism, and as a result, most critiques of Marxist literary theory come from the Left. ${ }^{200}$ We will now assess some of these critiques and their significance.

The strongest criticism of Marxist literary theory is that it is a kind of contradiction in terms. The concept of literature, on this account, is not a valid category of Marxist thought. We saw that in his later work, Macherey suggested that the concept was an ideological product. Left criticism has followed through this notion at length. Tony Bennett laid the foundations for this kind of thought in Formalism and Marxism (1979). He argues there that literature is a bourgeois concept, and that any attempt to analyse it as such or to practise a discourse of which it is the proper object fails to make a properly Marxist break with bourgeois method. He writes:

Marxist literary criticism..., far from progressing by displacing the concerns of bourgeois aesthetics to produce a distinctively new set of problems, has been developed chiefly by a series of borrowings from the more developed... system of bourgeois criticism. ${ }^{201}$

\footnotetext{
${ }^{200}$ Because of this lack of common ground, conservative critics tend to ridicule Marxist criticism as a kind of category mistake that should never have been attempted. Roger Kimball's articles, 'The Contradictions of Terry Eagleton' and 'Fredric Jameson's Laments', The New Criterion 9 (1990) pp. 17-23; 10 (1991) pp. 9-17, exemplify this approach.

${ }^{201}$ Tony Bennett, Formalism and Marxism (London: Methuen, 1979) p. 100.
} 
Bennett argues that the trans-historical category of literature presupposes a formal essence shared by the texts in that genus, which cannot be thought of in materialist terms. ${ }^{202}$ This is the basic error of Althusserian criticism, in his view. Althusser's suggestion that art makes us see ideology 'simply assumes that there is some... set of common features' to art and to its subset literature, which criticism can describe. ${ }^{203}$ The theory of literature as a mode of cognition midway between science and ideology, Bennett writes, cannot answer the properly materialist question of the different historical and material determinants that have produced the texts described as literary. ${ }^{204}$ Bennett calls this first principle of Althusserian literary criticism a 'new idealism', whose 'epistemological ballast' Marxist criticism must jettison. Literature cannot be conceived as an essence by Marxism, he writes, even of a mode of cognition. It does not produce ideological forms and reveal them, as Macherey and Eagleton argued; on the contrary it is Marxist criticism that makes texts perform that function. ${ }^{205}$ For Bennett, the production of knowledge of the contradictions of an ideology, which Macherey and Eagleton attribute to literary texts, is a product of Marxist criticism.

Eagleton's defence of the concept of aesthetic value in Criticism and Ideology is a focal point of this critique. In a 1980 interview, Eagleton acknowledged that his defence contained an 'apparent contradiction' (between intrinsic and extrinsic determinants of aesthetic value) but he denied that it was real. He also defended the enduring importance of the question of value for Marxist

\footnotetext{
${ }^{202}$ Ibid. p. 105.

${ }^{203}$ lbid. p. 121

204 Ibid. p. 132.

${ }^{205}$ Ibid. p. 141
} 
criticism. ${ }^{206}$ Bennett, however, insists that that 'there neither is nor can be a science of value', because value is not an attribute of a text but a product of criticism. ${ }^{207}$ Whilst Eagleton describes a series of categories for materialist analysis, Bennett points out that he does not use them in practice, 'since he has already defined literature in idealist terms ${ }^{2}{ }^{208}$ Eagleton vacillates between two concepts of literature, Bennett argues, as imaginative writing in general and as a particular (valuable) species of that genus. ${ }^{209}$ He rejects Eagleton's definition of aesthetic value by the degree of a text's internal distantiation of ideology, writing that 'there is simply no way in which a given text can be said to be valued because of the circumstances of its production'. ${ }^{210}$ This is true. In fact, Eagleton's definition of the valuable text does not differ from his account of the literary text per se. Both the text and the valuable text, in the last analysis, are defined by their internal display of the contradictory relation of the ideology of which they are products to history. The materialist terms to which he restricts himself do not account for the problem of value he sets out to solve.

In 'Literary Theory, etc.' (1987), Stephen Heath criticises the concept of literature in Eagleton's work. He notes that while Eagleton is always concerned to inscribe an 'outside' into his work, that is, to gesture away from literature towards social and material reality, he does so from within the field of literary studies. ${ }^{211}$ This is to say that in practice the bourgeois ideology of literature, into which Eagleton is institutionally inserted, debilitates the scientific and political

\footnotetext{
${ }^{206}$ Kavanagh and Lewis, op. cit. p. 62.

${ }^{207}$ Bennett, Formalism and Marxism pp. 172-173.

208 Ibid p. 149.

209 Ibid. pp. 151-152.

210 Ibid. p. 154.

211 Stephen Heath, 'Literary Theory, etc.', Comparative Criticsm 9 (1987) p. 287.
} 
value of his work. By institutionally complying with the ideology of literature, Eagleton's work remains more or less useless in the reality of the class-struggle.

In Outside Literature (1990), Bennett argues that the concept of Marxist literary theory needs to be abandoned altogether. It is hopelessly bound up with bourgeois concepts, he asserts. Its goal is an 'accommodation between the historical and materialist bent of Marxist categories and the universalising disposition of bourgeois concepts of art, literature and the aesthetic'. ${ }^{212}$ This kind of synthesis is impossible, for Bennett, and the attempt to effect it only results in the 'bourgeoisification' of Marxist discourse. ${ }^{213}$ When a system as polysemous as Marxism encounters an object as chimerical as literature, he argues, the results are so uncertain that a paradigm shift is necessary. For Bennett, this means 'postMarxism", or broadly socialist thought indebted to Marxist tradition but that definitively breaks with it. ${ }^{214}$ In his argument for this kind of discourse, Bennett attacks Eagleton's later work. He is critical that Eagleton accepts that the task, of revolutionary consciousness-formation, which he outlines for criticism is not presently likely to be accomplished. Bennett describes this as a 'critical recidivism' that produces an 'antinomial' way of thinking, removed from present concerns. $^{215}$ In Bennett's view, Eagleton's attempt to inscribe a social space for criticism will effect in it precisely the same kind of political impotence that it suffered as it was institutionalised in British universities at the turn of the century. ${ }^{216} \mathrm{He}$ writes, 'In recalling criticism to its traditional function, Eagleton... recalls it to its traditional dilemma also: ${ }^{217}$ The essence of this error,

\footnotetext{
212 Tony Bennett. Outside Literature, London and New York: Routledge, 1990 p. 31.

213 Tbid p. 32.

${ }^{214}$ Ibid. p. 17.

215 Ibid. p. 223

${ }^{216}$ Ibid. p. 225

${ }^{217}$ Ibid. p. 230
} 
for Bennett, is the concept of a single function of criticism, which it more or less fulfils at different times and places. He writes that one should ask rather 'what roles might be performed by different types of critical practice given the varied institutional domains and the varied publics in which such practices are operative'. ${ }^{218}$ Again Eagleton is too concerned with trans-historical essences, and consequently fails to attend to the specific situation of the present and to practical means of its redress, which, Bennett argues, must be the first principle of socialist cultural study.

Bennett's post-Marxist critique joins the conservative critique in asserting that Marxist literary theory is a kind of category mistake. It constitutes a serious criticism. Bennett is right to assert that Marxist theory cannot account for the phenomenon of literary value. Where it explicitly or implicitly asserts that there is a substantial reality that corresponds to the concept of literary value, it ceases to be properly Marxist. We should take this as an index of the incomplete scope of Marxist criticism, and remember that as a result it cannot provide a comprehensive account of a literary text. I do not agree with Bennett that the concept of value should be abandoned altogether, and that literary criticism should be transformed into the study of cultural production alone. For one thing, we have seen that there are no compelling reasons why we should accept such a change (from ideology to science). Although we can agree that value is contextdetermined, we should not conclude from this that it is meaningless or an ideological misrepresentation in its context. That is to say that if a certain text is valuable to me here and now, that value is neither negated nor shown to be illusory because the text may have a different value for another person in another 
time and place. I will develop these arguments further in the fifth chapter. For now, we can note that what Bennett makes quite clear is that Marxist criticism cannot account for value in literature. We should remember as we use its methods that they will not provide us with a complete account of a literary text. Whilst Christian literary theory should use all the insights it can gain from Marxist criticism concerning the cultural production of texts, it should also remember that their cultural production does not exhaust the meaning of those texts. 


\section{On Psychoanalysis}

I will conclude my examination of the fundamental discourses of modern literary theory with a study of psychoanalytic theory and criticism. As in my analyses of deconstruction and Marxism, I shall have two fundamental concerns. Firstly, I will examine the relations between psychoanalysis and Christianity and the mutual effects of these discourses on one another, in order to assess the ways in which Christian literary theory can or should use psychoanalytic methodology. Secondly, I will offer a critique of psychoanalysis, in order to suggest that it should not be taken as authoritative for literary theory. As before, I will begin with an introduction to those psychoanalytic theories with which I will be concerned.

\section{(i) An Outline of Psychoanalytic Literary Theories}

Psychoanalysis is widely used, in various derivative forms, in literary and cultural studies today. Lacanian criticism in particular is used in feminist, gay and other approaches that emphasise gender or sexuality. It would require a whole thesis to describe all the critical uses to which all the varieties of psychoanalysis have been put, and in this section I will restrict my discussion to the most fundamental and influential theories and critical methods. 


\section{Sigmund Freud}

Sigmund Freud (1856-1939) began practice as a neuropathologist in 1886 after having achieved modest success in the field during his training at the Vienna General Hospital. He was influenced by the work of the neurologist Jean Martin Charcot, under whom he spent some months working in Paris in 1885-6. Charcot had discovered a relation between hypnosis and hysteria, and had suggested that ideas determined hysterical symptoms rather than anatomy. Freud had also been impressed by the treatment of hysteria with hypnotism by his colleague Josef Breuer. In the late 1880 s and early 1890 s he began to experiment with Breuer's 'cathartic' method in the treatment of his own patients.'

Freud was always as concerned with knowledge as with therapy. In this respect, his 'Project for a Scientific Psychology'(1895) serves as a useful introduction to his work. He begins this essay by establishing two first principles from which he never departed, namely materialism and mechanism. He writes, 'The intention is to furnish a psychology that shall be a natural science: that is, to represent psychical processes as quantitatively determinate states of specifiable material particles'. ${ }^{2}$ The work attempts to explain the phenomena of psychology by means of the data of neuro-physiology. The two principles with which Freud undertakes this task are ' 1 . What distinguishes activity from rest is to be regarded as Q [i.e. quantity], subject to the general laws of motion'. This is the mechanistic first principle, according to which mental phenomena are to be understood as a determinate distribution of quantities in the mind. ' 2 . The

\footnotetext{
${ }^{1}$ See Ernest Jones, Sigmund Freud: Life and Work (London: Hogarth, 1953-1957) Vol. 1 for biographical information on the earlier part of Freud's life.
} 
neurones are to be taken as the material particles'. ${ }^{3}$ This is the materialist principle, according to which the mind is composed of material units, the neurones. The fundamental operational principle of the mind so conceived Freud calls the 'principle of neuronal inertia', or the 'principle of constancy'. This states that neurones tend to divest themselves of the quantity of mental energy or excitation Freud calls Q. If the mental system experiences an increase of stimulus, it tends to discharge it by means of an expenditure of a proportionate quantity of energy. Freud calls this the 'primary function' of the mental apparatus. There are two sources of mental stimulus, those external and those internal to the individual organism. The organism cannot withdraw from internal stimuli (such as hunger) as from external ones, and so needs a store of internal energy Freud calls $\mathrm{Q} \eta$ to meet the demand for action such stimuli generate. Maintaining this store is the 'secondary function' of the mind. Although it appears to contradict the primary trend to inertia, it follows that trend in keeping the amount of Q $\eta$ as low as possible. In Beyond the Pleasure Principle (1920), Freud described the structure of these two processes as the relation between the death instincts and the sexual instincts. ${ }^{5}$ Freud links the hypothesis of stimulus and discharge to contemporary histology, according to which the nervous system is composed of neurones that have contact with one another through another substance, protoplasm. Energy passes from one neurone to another through this substance, which offers a greater or lesser degree of resistance to its passage.

\footnotetext{
${ }^{2}$ The Standard Edition of the Complete Psychological Works of Sigmund Freud, tr. and ed. James Strachey et al (London: The Hogarth Press and the Institute of Psycho-Analysis, 19531974) Vol. I p. 295. This edition will henceforth be abbreviated as 'SE'.

${ }^{3}$ Ibid.

${ }^{4}$ Ibid. p. 296.

${ }^{5}$ SE XVIII pp. 34-64. 'One group of instincts rushes forward so as to reach the final aim of life as swiftly as possible...the other group jerks back to a certain point to make a fresh start and so prolong the journey' (ibid. p. 41).
} 
Because of this resistance Freud describes neurones as linked by 'contactbarriers'. ${ }^{6}$ This concept allows him to explain the phenomenon of memory, which he sees as the 'capacity [of nervous tissue] for being permanently altered by single occurrences'. The hypothesis of contact-barriers leads Freud to argue that there must be two classes of neurone. There must be those which allow Q $\eta$ to pass through them as if there were no barrier to its passage, and those through which it passes only partially or with difficulty. The first, permeable class would be the vehicles of perception, and the second resistant class the vehicles of memory. Freud calls them $\phi$ and $\psi$ respectively. In the 'project', he asserts that the passage of energy through the $\psi$-neurones' contact-barriers both permanently alters those barriers and in doing so makes the future conduction of energy through them easier. The degree of facility of conduction thus effected in the $\psi$ neurones Freud calls their degree of 'facilitation' [bahmung]. Memory, then, which is one of the determinants of the path of energy through the system, is 'represented by the differences in the facilitations of the $\psi$-neurones'. preference of one form of action over another that is in psychological terms a function of memory is explained in neuro-physiological terms by the greater facilitation of one pathway through the $\psi$-neurones than another.

Like most of Freud's later work, the 'Project' combines bold speculation with a desire for empirical precision. This combination characterises his contributions to the Studies in Hysteria he and Breuer published in the same year, 1895. The most significant of these studies was that of Breuer's patient 'Anna O', whom he had treated between 1880 and 1882. Anna $O$ became ill at twenty-one, after

\footnotetext{
${ }^{6}$ Ibid. p. 298.

Tbid. p. 299.

${ }^{8}$ Ibid. p. 300 .
} 
nursing her dying father. She exhibited a series of hysterical symptoms, including paralysis, coughing, and periodic inability to speak her native German. She also experienced a worsening condition Breuer calls 'absence' or 'condition seconde, in which she hallucinated, behaved violently and eventually worked herself into a kind of auto-hypnotic state. ${ }^{9}$ During these absences, Anna O would mutter a series of words. Breuer found that if he repeated these words to her in her hypnotic state and invited her to follow the train of thought they initiated, she would relate the thoughts by which she had been occupied during her absence. When she did so, she was relieved of its conditions and temporarily restored to normal mental life. She called this process the 'talking-cure' or 'chimneysweeping' ${ }^{10}$ Breuer further discovered that if she could be brought, under hypnosis, to remember and relate the first appearance of her symptoms, she would be permanently relieved of them. He established that her inability to drink derived from disgust at seeing a companion's dog drink out of a glass of water during the period she was nursing her father. She had not expressed her disgust at the time out of politeness. When she related this experience under hypnosis, her inability to drink disappeared. ${ }^{11}$ Breuer found that almost all of her symptoms could be removed in this way. ${ }^{12} \mathrm{He}$ also found that they emerged with the greatest force during this process. Freud regarded these discoveries as the foundations of psychoanalysis. ${ }^{13}$ In the 'Preliminary Communication' (1893) to the Studies on Hysteria, he and Breuer write that "hysterics suffer mainly from

\footnotetext{
${ }^{9}$ SE II p. 24.

${ }^{10}$ Ibid. p. 30.

"Ibid. p. 34.

${ }^{12}$ Ibid pp. 34-37.

${ }^{13}$ The Penguin Freud Library, ed. Angela Richards and Albert Dickson (London: Penguin, 19731986) Vol. 1 pp. 111, 321; SE XI p. 9; SE XIV pp. 8-12. The Penguin edition will hereafter be abbreviated as 'PFL'.
} 
reminiscences'. ${ }^{14}$ Hysterical symptoms, that is, are related to a series of emotional experiences, or 'psychical traumas', which remain unconscious in the patient's normal mental condition. ${ }^{15}$ The symptoms display their connection to this trauma, and can be described as 'precipitates' of them. ${ }^{16}$ When brought to consciousness, the memories of these traumatic experiences are discharged of their affect, that is, of the emotional states attached to the memory-images. The symptoms were precipitated as a result of the lack of this kind of discharge or 'abreaction', and when the memories and their affects are afforded release, the symptoms subside. ${ }^{17}$

Freud became dissatisfied with the efficacy of hypnosis in the treatment of his own patients, only a fraction of whom proved susceptible to it. So he decided to 'start from the assumption that my patients knew everything that was of any pathogenic significance and that it was only a question of obliging them to communicate it'. ${ }^{18}$ The method he found most effective for bringing about this communication was that of free association, in which the patient voices the first things that come into his mind when considering a given phenomenon. In treating hysterical patients this way, it became apparent to Freud that the closer the patient's associations came to the pathogenic ideas, the greater the 'resistance' shown by the patient to bringing them into consciousness. To account for this phenomenon, Freud hypothesised a reverse process of 'repression'. If a patient resists bringing to consciousness certain unconscious mental states, that is, it must be because there is a mental force that keeps them unconscious. He writes, 'A violent opposition must have started against the entry

\footnotetext{
${ }^{14}$ SE II p. 7.

${ }^{15}$ Ibid. p. 5 .

${ }^{16}$ Ibid. p. 4

${ }^{17}$ Ibid. p. 17.
} 
into consciousness of [a] questionable mental process, and for that reason it remained unconscious'. ${ }^{19}$ Pathogenic ideas, according to Freud, have been rejected from consciousness because they tended towards a socially impermissible satisfaction. The ego, whose function is to adapt the individual to the exigencies of his situation, prevents such an idea turning into action by keeping it unconscious. The idea and its affect remain in the individual's 'unconscious', which Freud conceives as 'a special region of the mind, shut off from the rest. ${ }^{20}$

The phenomena that provided Freud with the clearest knowledge of the unconscious were dreams. Along with free association, dream-interpretation became a fundamental method of psychoanalytic therapy. The biological purpose of sleep, according to Freud, is the withdrawal of the organism from the stimuli of the external world. ${ }^{21}$ Nevertheless external and internal stimuli continue to impinge upon it. Dreams are a reaction to these stimuli, a means of discharging them, in order that sleep can continue. Freud writes, 'Dreams are not disturbers of sleep... but guardians of sleep which get rid of disturbances ${ }^{22}$ He sees this to be clearly demonstrated by children's dreams, where the instinctual stimulation of hunger, for example, can be discharged by a dream of pleasant food. ${ }^{23}$ For Freud, dreams deal with disturbing stimuli by producing substitutive representations of them, such as a dream of church-bells in response to the sound of an alarm clock. When the stimulus derives from the dreamer himself, Freud hypothesises, it must be possible to work back from the dream-representation to

\footnotetext{
${ }^{18}$ Ibid. p. 110.

${ }^{19}$ Introductory Lectures on Psychoanalysis, PFL 1 p. 335.

${ }^{20}$ Ibid. p. 318.

${ }^{21}$ Tbid. p. 117.

22 Ibid. p. 160.

${ }^{23}$ Ibid pp. 157-167.
} 
the mental event it represented. Freud calls this material the 'latent dreamthoughts'. The remembered images and affects of the dream he calls the 'manifest dream-content ${ }^{24}$ By applying the law of determinism to mental life, Freud hypothesised that the latent thoughts could be brought into consciousness by means of free association from the manifest content. The results of this kind of experiment along with the data from children's dreams, in which the distortion is less pronounced, led Freud to conclude that "whenever a dream has been completely intelligible to us, it has turned out to be the hallucinated fulfilment of a wish ${ }^{25}$ The occurrence of resistance at certain points in the relating of dreams and in associations based on them led Freud to posit a censorship function exercised by the sleeper's ego, which judges these wishes and distorts beyond recognition those which would not be admitted to waking consciousness. ${ }^{26}$

The mind transforms these forbidden wishes into dream-representations in two ways, according to Freud. Firstly, it uses an apparently phylogenetic heritage of symbols, mostly for sexual objects, genitals, family members, lovers and so on. ${ }^{27}$ Secondly it performs what Freud calls the 'dream-work' ${ }^{28}$ This process gives the greatest insight into the 'primary process', or the way in which the unconscious functions. It is inferred from the comparison of dream-interpretations to the dreams of which they are judged to be correct interpretations. It consists fundamentally of three kinds of labour. The first is 'condensation' or

\footnotetext{
${ }^{24}$ Ibid. pp. 150-151.

${ }^{25}$ Ibid. p. 168.

${ }^{26}$ Ibid. p. 175 .

${ }^{27}$ Ibid. ch. 10; Freud describes dream-symbolism at length in The Interpretation of Dreams, PFL

4 pp. 466-529.

${ }^{28}$ PFL 1 p. 204.
} 
compression (verdichtung). ${ }^{29}$ By this process several latent elements which have something in common are fused into one element in the manifest dream. A similar process is observable in jokes which condense two thoughts into one ambiguous word. The second work is 'displacement' or shifting (verschiebung), either of an image or of affect. ${ }^{30}$ In the first case, a latent thought is represented by a manifest image to which it is connected only remotely. In the second case, what is most important or urgent in the latent thoughts is represented as a relatively unimportant part of the manifest dream. The dream is thus 'differently centred' from the dream-thoughts. ${ }^{31}$ The third work Freud calls 'considerations of representability', by which latent thoughts are transformed into manifest images. ${ }^{32}$ The thought of possessing (besitzen) a thing, for example, could be represented by the image of sitting (sitzen) on it. A broken marriage might be represented by a broken leg. ${ }^{33}$ A significant feature of this aspect of the dreamwork is that it does not recognise conceptual relations, such as causality or contrariety. Freud also notes the process of 'secondary revision', by which sense is made out of the dream in waking life. ${ }^{34}$

As he interpreted his patients' dreams, Freud found that the forbidden thoughts distorted in them bore the uninhibited characteristics not only of human prehistory but also of individual prehistory. The aggression and sexual energy or 'libido' which proved to be the stimulus of dreams corresponded to the impulses of early childhood that were repressed from the conscious system as the child learnt the practical necessity of renouncing them. Hence Freud writes, 'What is

\footnotetext{
${ }^{29}$ lbid. p. 205.

${ }^{30}$ Ibid. p. 208.

${ }^{31}$ PFL 4 p. 414.

${ }^{32}$ lbid. p. 454.

${ }^{33}$ PFL 1 p. 210.

${ }^{34}$ lbid. p. 216.
} 
unconscious in mental life is also what is infantile'. ${ }^{35}$ In his Three Essays on the Theory of Sexuality (1905), Freud describes children up to the age of about five as 'polymorphously perverse', by which he means that they have a predisposition towards all the satisfactions that in an adult would be described as perversions. ${ }^{36}$ These impulses are gradually organised in healthy development around the reproductive function. Freud takes thumb-sucking as an example of infantile sexuality. The pleasure generated by the activity was originally associated with a vital function, from which it has gradually become independent. The lips and mouth were initially stimulated whilst the infant was sucking at its mother's breast, and this pleasure is now obtained in the absence of this activity. Freud calls such pleasure 'auto-erotic', that is, derived from the infant's own body. ${ }^{37}$ Auto-erotic stimulation of a zone associated with a vital function characterises infantile sexuality for Freud. As the child grows, it discovers the pleasure generated by stimulation in the anal zone, which it can produce by accumulating a certain amount of stool before defecation. These pleasures characterise what Freud calls the 'pre-genital' organisations of sexuality. ${ }^{38}$ These organisations subordinate the polymorphous "component instincts' to activity dominated by a particular erotogenic zone. In the 'oral' or 'cannibalistic' organisation sexual activity (in the sense defined above) is identified with the ingestion of food. In the second 'sadistic-anal' phase, it is split into active and passive currents, as the infant controls defecation (activity) and experiences anal stimulation as a result (passivity). ${ }^{39}$ In 'The Infantile Genital Organisation' (1923), Freud described a 'phallic' stage, in which the

\footnotetext{
${ }^{35}$ Ibid. p. 247.

${ }^{36}$ SE VII p. 191.

${ }^{37}$ Tbid. p. 181.

${ }^{38}$ Ibid. p. 197.
} 
libido of both sexes is organised around a fascination with the penis. ${ }^{40}$ The goal of development is the 'genital' organisation, in which all the component sexual instincts are subordinated to the pleasure derived from the genital zone and hence the reproductive function. This occurs at puberty, and is often anticipated by various educational prohibitions. ${ }^{41}$

As the sexual 'aim', that is the kind of act from which pleasure is derived, develops during childhood, so too does the sexual 'object', that is, the person or thing towards which the instincts are directed. For the sake of simplicity, we will describe the development of the male child in this respect. ${ }^{42}$ At an early point in the infantile stage, the child develops an 'object-cathexis', that is, an investment of sexual energy, for its mother, which derives from its earliest relation to her breast. ${ }^{43}$ At the same time, he identifies with his father, that is, takes him as an ideal image of himself. ${ }^{44}$ As he progresses to the phallic organisation of his libido, the boy's sexual wishes towards his mother intensify, and his father is perceived as a threat to them. His identification with his father thus becomes 'ambivalent', taking on a hostile tendency and a wish to replace him in his mother's affections. ${ }^{45}$ This orientation is the basis of the 'Oedipus complex'. ${ }^{46}$ This complex of wishes, in Freud's view, is the phylogenetic and ontogenetic heritage of every human being. We have described it so far in what Freud calls

\footnotetext{
${ }^{39}$ Tbid. p. 198.

${ }^{40}$ SE XIX pp. 142-145.

${ }^{41}$ Ibid. p. 199.

${ }^{42}$ As we will see below, there are several problems with Freud's account of the development of girls. After a series of theories, certain phenomena of fernale psychology eventually forced him to retract his argument for the universality of the Oedipus complex. See 'Female Sexuality', SE XXI p. 227.

${ }^{43}$ See 'The Ego and the Id', SE XIX p. 31 . Here we elide the account of narcissism, in which the ego initially cathects itself with libido before any external object-choice. See 'On Narcissism', SE XIV pp. 163-190.

${ }_{44}^{44}$ See 'Group Psychology and the Analysis of the Ego', SE XVIII p. 105.

${ }^{45} \mathrm{Jbid}$.

${ }^{46}$ SE XIX p. 32.
} 
its 'simple positive' form. ${ }^{47} \mathrm{He}$ writes that the innate bisexuality of children determines a parallel negative version of the complex, in which the boy displays an affectionate attitude towards his father and a corresponding jealousy of his mother. Healthy human development is contingent upon the successful dissolution of the Oedipus complex at the end of the period of infantile sexuality. A broad 'experience of painful disappointments' brings about this dissolution, most significant among which is the "threat of castration'. ${ }^{48}$ During the phallic phase of libidinal development, the boy tends towards masturbation as a means of fulfilling his Oedipal wishes. ${ }^{49}$ Disapproving adults may threaten him with some kind of castration, as Freud found in the case of 'Little Hans' ${ }^{50}$ If so, he initially disbelieves the possibility, but when he first sees female genitals, he infers that women have been castrated. The threat becomes a real possibility to him. ${ }^{51}$ This leads him to turn away from or repress the Oedipus complex, since in its positive form he imagines that castration will ensue as a punishment, and in its negative form it must occur as a precondition. He replaces his object-cathexes with identifications with his parents. He 'introjects' their prohibitions against incest, that is, sets them up as objects within his own ego, where they form the basis of his 'super-ego' or conscience. ${ }^{52}$ His libidinal energy is 'sublimated' into non-sexual aims and inhibited into affection. ${ }^{53}$ The more completely this repression is carried out, the greater the disposition to mental health of the adult.

\footnotetext{
${ }^{47}$ Ibid. p. 33.

48 'The Dissolution of the Oedipus Complex', SE XIX pp. 173, 175.

${ }^{49}$ Ibid. pp. 174, 176.

${ }^{50}$ SE X pp. 30-36.

${ }^{51}$ SE XIX p. 176
} 


\section{Freudian Literary Criticism}

In The Interpretation of Dreams (1900), Freud had linked the emotional force of Sophocles'Oedipus Rex with the repressed wishes of its audience. He writes, '[Oedipus'] destiny moves us because it might have been ours...[He] merely shows us the fulfilment of our childhood wishes'. ${ }^{54}$ In 'Creative Writers and Daydreaming' (1908), Freud sets out his fundamental aesthetic thesis, that art allows us access to forbidden pleasures. He links creative writing to children's play, in that both involve the rearrangement of reality into a strongly cathected fictional form. ${ }^{55}$ The adult equivalent of play is the daydream, in which wishes, typically egocentric or erotic, are imaginatively fulfilled. Many literary works are analogous to daydreams, in that they have a hero of some kind, who is the centre of interest and lives a providentially protected life. He often has a series of amorous encounters. They are in short precisely the same kind of imaginary wish-fulfilment as can be found in daydreams, according to Freud. To prevent his egocentric wishes arousing the reader's disgust, the writer clothes them in aesthetic form. Freud professes ignorance concerning the nature of form, but he conceives of it as a kind of bribe offered to the reader in order that he should accept the writer's fantasies. He calls it an 'incentive bonus' or 'fore-pleasure'. ${ }^{56}$ By consciously reading the work in order to derive pleasure from its aesthetic form, the reader can unconsciously experience the pleasure of the writer's fantasies as if they were his own. Freud writes, 'Our actual enjoyment of an

\footnotetext{
${ }^{52}$ See 'The Ego and the Id', ch. III. The character of the super-ego depends on the specific combination of maternal and paternal identifications from which it is formed.

${ }^{33}$ Se XIX p. 177.

${ }^{54}$ PFL 4 p. 364.

${ }_{55}^{55}$ PFL 14 p. 132.

${ }^{56}$ Ibid. p. 141.
} 
imaginative work proceeds from a liberation of tensions in our minds' ${ }^{57}$ With our conscience satisfied that we are enjoying a formal pleasure, we are free to enjoy the forbidden pleasures of egocentric and erotic fantasy.

In 'The "Uncanny" (1919), Freud again professes his lack of competence in aesthetics, but finds himself qualified to analyse the production of certain affects by literary works. In this essay he examines the unheimlich, the 'uncanny', sinister or spine-chilling affects, in E.T.A. Hoffmann's story 'The Sand-Man' (1816). Freud had long been impressed by the observation of the philologist Karl Abel that in many ancient languages words that denoted the most fundamental of concepts also denoted what now appears to be their opposite. ${ }^{58}$ The Latin word sacer, for example, means both 'sacred' and 'profane'. Freud points out that the German word heimlich works like this. Its fundamental meaning is 'homely' or 'familiar', but it extends to states of such close familiarity or intimacy as to mean 'clandestine' or 'forbidden'. ${ }^{59}$ It can thus slip into the same meaning as its apparent opposite, unheimlich, 'eerie' or 'uncanny'. 60 Both can denote something that should remain hidden or out of normal view. Freud finds that the chief source of uncanny affect in 'The Sand-Man' is the ghostly title figure, whom the hero's nurse described to him in childhood as someone who would tear out his eyes. According to Freud, 'psycho-analytic experience' suggests that 'anxiety about one's eyes, the fear of going blind, is often enough a substitute for the dread of being castrated'. ${ }^{61}$ Freud notes that in the story, anxiety about the eyes is related to the death of the hero's father and that the Sandman appears as a disturber of love. These facts corroborate his assertions that the Sandman

\footnotetext{
${ }^{57}$ Ibid.

${ }^{58}$ See his review article 'The Antithetical Meaning of Primary Words', SE XI pp. 151-161.

${ }^{59}$ Today, this is the word's primary meaning.

${ }^{60}$ Freud. 'The "Uncanny", SE XVI pp. 222-226.
} 
represents 'the dreaded father at whose hands castration is expected', and that the uncanny affect the character produces in the reader is related to the anxiety belonging to the castration complex of childhood' ${ }^{62}$ Freud goes on to derive uncanny experience in general from a factor of 'involuntary repetition', which he relates to the 'compulsion to repeat' driven by the death-instinct. ${ }^{63} \mathrm{He}$ writes that 'whatever reminds of us of this inner 'compulsion to repeat' is perceived as uncanny'. ${ }^{64} \mathrm{He}$ concludes that the uncanny is the subset of frightening experience in which the frightening element is the recurrence of something repressed. This explains the linguistic phenomenon that the meanings of the words heimlich and unheimlich converge. The uncanny is that which is both profoundly familiar and also hidden ('heimlich') from consciousness by the process of repression. ${ }^{65}$ Freud concludes that, at least in realistic literary works, an uncanny effect is produced by an impression that reminds the reader of a repressed infantile complex. ${ }^{66}$

\section{Jacques Lacan}

Jacques Lacan (1901-1981) explored the connections between psychiatry and psychoanalysis in his doctoral thesis on paranoia, published in 1932, and became a full member of the Société Psychoanalytique de Paris six years later. In 1953 he resigned from this organisation and hence from the International

\footnotetext{
${ }^{61}$ Ibid. p. 231.

${ }^{62}$ Tbid. pp. 232, 233.

${ }^{63}$ Tbid. pp. 237. 238. See 'Beyond the Pleasure Principle', SE XVIII pp. $18 \mathrm{ff}$.

${ }^{64}$ SE XVII p. 238.

${ }^{65}$ Ibid. p. 241.

${ }^{66}$ Tbid. p. 249. In 'Delusions and Dreams in Jensen's Gradiva' (1907), PFL 14 pp. 3-18. Freud reads the plot and characters of Jensen's story in psychoanalytic terms. In The Life and Works of Edgar Allen Poe (London: Imago. 1940), one of the most distinctively Freudian works of
} 
Psychoanalytic Association, to form the Société Française de Psychanalyse. This was characterised by an opposition to ego-psychology, in which the ego is seen as the basis of mental stability, and by an understanding of Freud through the ideas of Hegel, Heidegger and Saussure. In 1964 Lacan formed the École Freudienne de Paris and conducted his weekly seminar from the École des Hautes Études.

Lacan contributed the 'mirror stage' to the psychoanalytic theory of mental development. He introduced the idea at the International Psychoanalytical Congress in 1936, and elaborated on its consequences in 'The Mirror Stage as Formative of the Function of the I' (1949). In this paper, he argues that between the ages of six and eighteen months an infant will recognise his own image in a mirror, or in another person imitating his movements. He playfully experiences the contrast between his apparent control of the image and his lack of control of his own motor functions. He 'identifies' with the image, that is, he begins to form an idea of himself based on the image. ${ }^{67}$ It is large and whole, in contrast to his small size and turbulent experience, and he anticipates that he will eventually assume its characteristics. Lacan writes, 'The mirror stage is a drama whose internal thrust is precipitated from insufficiency to anticipation' ${ }^{68}$ The significance of this thrust is that it 'situates the agency of the ego...in a fictional direction' ${ }^{69}$ The ego, that is, is a misrepresentation of the subject. Lacan sees in the distress caused by the motor incapacity and the anarchic desires of infants a 'real...prematurity of birth' in man. This uncoordinated and dependent creature

\footnotetext{
psychoanalytic criticism, Marie Bonaparte reads Poe's work as a series of symptoms whose determination she establishes from his biography.

${ }^{67}$ Freud describes the process of identification in the formation of the ego in 'Group Psychology and the Analysis of the Ego' ch. VII. SE XIX pp. 105-110.

68 Jacques Lacan. Ecrits: A Selection, tr. Alan Sheridan (London: Routledge, 1977) p. 4.

${ }^{69}$ Ibid. p. 2.
} 
is 'captivated' by the 'lure' of the well-formed and controlled body it sees in the mirror, and assumes it as 'the armour of an alienating identity'. ${ }^{70}$ The ' $\mathrm{I}$ ' or the 'self' is constituted by what Lacan calls a méconaissance, a wilful misrecognition or misunderstanding, of the inner disorder and fragmentation of the subject, which it serves to keep unconscious. ${ }^{71}$ It is an 'organisation of the passions' caused by the subject's desire for an identity he does not in reality possess. $^{72}$

In 'Language and the Analysis of Social Laws' (1951), the anthropologist Claude Lévi-Strauss (b. 1908) had posed the question whether the structures of kinship and the structure of language were not projections of 'universal laws which regulate the unconscious activities of the mind' ${ }^{73}$ In 'The Function and Field of Speech and Language in Psychoanalysis' (1953), Lacan offers an answer to this question. He writes that psychoanalysis occurs entirely in the dimension of speech, in which the patient restructures his history through speech that is addressed to the analyst. He redefines the unconscious as 'that part of the concrete discourse, insofar as it is transindividual, that is not at the disposal of the subject in re-establishing the continuity of his conscious discourse ${ }^{74}$ It is the censored chapter in the history which the patient makes for himself by relating it to the analyst. Lacan writes, 'The unconscious of the subject is the discourse of the other'. ${ }^{75}$ It is what emerges in the subject's discourse that he has not intended to express. In 'The Freudian Thing' (1955), Lacan expresses this in the formula

\footnotetext{
${ }^{70}$ Tbid. p. 4.

7 lbid. p. 6

${ }^{72}$ Ibid. p. 19

${ }^{73}$ Claude Lévi-Strauss, Structural Anthropology, tr. Claire Jacobson and Brooke Grundfest Schoepf (London: Penguin, 1963) p. 59. Lévi-Strauss described the 'structural laws' of the Freudian unconscious in his essay 'The Effectiveness of Symbols', in ibid. pp. 186-205.

${ }^{74}$ Lacan. $\dot{E}$ crits p. 49.

${ }^{75}$ Ibid. p. 55.
} 
Ça parle, 'it/id speaks'. ${ }^{76}$ It 'speaks and functions in a way quite as elaborate as at the level of the conscious'. ${ }^{77}$ In his work on dreams, errors and jokes, Freud revealed that 'the unconscious is structured like a language'. ${ }^{78}$ The activity of the unconscious that Freud discerned in these phenomena is governed by the laws of language, according to Lacan.

Lacan thinks of language as it conceived by structural linguistics, that is, as a system of elements whose meaning consists in their difference from each other, and which operates by the selection and combination of these elements. ${ }^{79}$ Lacan calls this system the 'symbolic' order, 'in the sense that symbol means pact' ${ }^{80}$ The objects of exchange that constitute a primitive pact have no intrinsic use but signify the pact by virtue of their place within the system of exchange. ${ }^{81}$ Symbols, that is, derive their meaning from a system rather than from a subject. Consequently, 'symbols envelop the life of man in a network' which structures his life, and which may be said to be its law. ${ }^{82}$ Lacan writes, "The law of man has been the law of language since the first words' ${ }^{83}$ Lévi-Strauss had analysed the elementary structures of kinship as an exchange-system corresponding to the prohibition of incest. ${ }^{84}$ Lacan writes, "The primordial Law is...that which in regulating marriage ties superimposes the kingdom of culture on that of a nature abandoned to the law of mating'. 85 Lacan relates the law of language to the

\footnotetext{
${ }^{76}$ Ibid. p. 125 . 'Ca' is the standard French translation of Freud's term 'es', which the Standard Edition renders as 'id'.

${ }^{77}$ Lacan, The Four Fundamental Concepts of Psychoanalysis, tr. Alan Sheridan (London: Penguin, 1977) p. 24.

${ }^{78}$ lbid. p. 20.

${ }^{79}$ See Anika Lemaire. Jacques Lacan, tr. David Macey (London and New York: Routledge, 1977) pp. 12-66 for Lacan's debt to structural linguistics.

${ }^{80}$ Lacan. Écrits pp. 64. 61.

${ }^{81}$ Ibid. p. 61.

${ }^{82}$ Ibid. p. 68.

${ }^{83}$ Ibid. P. 61.

${ }^{84}$ Claude Lévi-Strauss. The Elementary Structures of Kinship, tr. James Harle Bell, John Richard von Sturmer and Rodney Needham (Boston: Beacon, 1969).

${ }^{85}$ Lacan, É crits p. 66.
} 
prohibition of incest that brings about the dissolution of the Oedipus complex, with the concept of 'kinship nominations'. He writes, 'It is in the name of the father that we must recognise the support of the symbolic function which... has identified his person with the figure of the law, ${ }^{86}$

In 'The Agency of the Letter in the Unconscious' (1957), Lacan describes in detail the relation of the unconscious to the structure of language. He takes Saussure's division of the linguistic sign into signifier and signified to imply two independent and 'non-overlapping networks' ${ }^{87}$ The system of the signifier can be shown to be dominant, according to Lacan, since it 'enters the signified'. His well-known example of this is a picture of two identical toilet doors, marked 'Ladies' and 'Gentlemen'. ${ }^{88}$ Though the signified in these two signs could strictly be said to be the same, the signifiers as it were enter into its realm, and divide it up by means of the chains of cultural associations that ramify from them. As a result, Lacan writes, 'We are forced...to accept the notion of an incessant sliding of the signified under the signifier ${ }^{89}$ He means that the system of signifiers works by reference to other elements in the system in a way that disrupts its correspondence to the system of signifieds. Like the symbolic order to which it belongs, 'the signifier' is an element of a system that is not centred on a subject. Lacan contrasts it to the sign, which 'represents something for someone'; a signifier, on the other hand, 'represents a subject for another signifier, ${ }^{90}$ Lacan describes a series of ways in which this system functions,

\footnotetext{
${ }^{86}$ Ibid. p. 67.

${ }^{87}$ Ibid. p. 126.

88 Ibid. p. 151.

${ }^{89}$ Ibid. p. 154.

${ }^{90}$ Lacan, The Four Fundamental Concepts p. 207.
} 
which can be reduced to two, 'metonymy' and 'metaphor'. 91 The essence of metonymy for Lacan is 'word-to-word connexion', and the essence of metaphor is substitution of 'one word for another'. ${ }^{92}$ The system of the signifier so conceived, he writes, is what Freud discovered and called the unconscious.

This is shown particularly clearly for Lacan in The Interpretation of Dreams. The dream, for Freud, is a rebus or picture puzzle. The images in this rebus work like signifiers as Lacan conceives them, that is, they signify other signifiers rather than their own immediate signifieds. The process of 'distortion' by which this occurs corresponds to what Lacan called the sliding of the signified under the signifier. The dream-work which effects this distortion follows the operation of the system of signifiers as Lacan conceives it. The work of condensation substitutes a manifest image for several latent thoughts, just as in Lacan's 'metaphor' one signifier is substituted for another. The work of displacement substitutes a manifest image or affect for a latent thought or affect distantly related to it, just as in Lacan's 'metonymy' one signifier connotes another related to it in the system. ${ }^{93}$ He concludes that "the dream-work follows the laws of the signifier'. ${ }^{94}$ For Lacan, this demonstrates that the unconscious is a system of signifiers. He writes, 'The unconscious is neither primordial nor instinctual; what it knows about the elementary is no more than the elements of the signifier'. ${ }^{95}$ This becomes apparent in neurotic symptoms, which are determined by the 'mechanism of metaphor', in that they are substitutions in the subject for the 'signifier of the sexual trauma'. The constant 'desire for something else' which

\footnotetext{
${ }^{91}$ Lacan owes this distinction to Roman Jakobson's essay 'Two Aspects of Language and Two Types of Aphasic Disturbances', Roman Jakobson and Morris Halle, Fundamentals of Language (The Hague and New York: Mouton, 1980) pp. 69-96. Jakobson compares the poles with Freud's dream-work differently to Lacan, however.

${ }_{92}$ Lacan, Ecrits pp. 156-157.

${ }^{93}$ Ibid. p. 160.
} 
structures the primary process operates according to the law of metonymy, seeking satisfaction in an object related in the signifying system of the unconscious to the forbidden object. ${ }^{96}$

\section{Lacanian Literary Criticism}

Lacan's seminars on aesthetic works use those works as illustrations of a psychoanalytic point rather than considering them in themselves. ${ }^{97}$ The most well-known of these discussions is Lacan's 'Seminar on "The Purloined Letter" (1956), in which he uses Edgar Allen Poe's story to demonstrate 'the decisive orientation which the subject receives from the itinerary of a signifier'. ${ }^{98}$ In his seminar of 1954-55, where the ideas were first presented, Lacan was expounding Beyond the Pleasure Principle. He sees the repetition-compulsion that Freud describes in that work to derive from the 'insistence of the signifying chain', that is, from the constitution of the subject by the symbolic order. ${ }^{99}$ Lacan argues that the plot of Poe's story is based upon two structurally similar scenes, in which different characters occupy the same positions in the structure. In both scenes, Lacan writes, three subject-positions are arranged around the letter of the story's title. The first subject looks at the letter but does not see it. The second sees that the first has not seen the letter and imagines that it is hidden. The third sees both

\footnotetext{
${ }^{94}$ Ibid. p. 161.

${ }^{95}$ Ibid. p. 170.

${ }^{96}$ Tbid. pp. 166-167.

${ }^{97}$ This is the case with his seminar on 'Desire and the Interpretation of Desire in Hamlet', tr. James Hulbert, Yale French Studies 55-56 (1977) pp. 11-52.

${ }_{98}$ Lacan, 'Seminar on the Purloined Letter', tr. Jeffrey Mehliman, Yale French Studies 48 (1972) p. 40. Poe's story is reprinted along with the critical debate provoked by Lacan's seminar in John P. Muller and William J. Richardsoll, eds.. The Purloined Poe: Lacan, Derrida and Psychoanalytic Reading (Baltimore and London: Jolıns Hopkins University Press, 1988).

${ }^{99}$ Lacan. 'Seminar on the Purloined Letter' p. 39.
} 
these positions and the letter. ${ }^{100}$ Lacan argues that the letter of the story's title can be taken to represent 'the signifier' in his sense of the term. Its path from character to character can be taken represent the symbolic order. In the story, the police make a detailed search of an apartment for the letter but fail to find it (because it is hidden in an obvious place, the letter-rack). For Lacan, this demonstrates that the signifier does not belong in the order of reality, but in another order. He writes, 'The letter is the symbol of a pact'. ${ }^{101}$ Symbols of a pact are the typical elements of the symbolic for Lacan, and so he writes that the letter belongs in the symbolic order. We never know what it symbolises, its contents, and Lacan argues that we do not need to know. Since the plot is governed by the movement of the letter from character to character, Lacan writes that it is the 'true subject' of the story, around which the characters arrange themselves. ${ }^{102}$ Lacan writes, 'The displacement of the signifier determines the subjects in their acts'. ${ }^{103}$ This is shown clearly in the repetition by different characters of the scene with which the plot begins in the scene with which it ends. Lacan writes, 'It is the letter and its diversion which governs their entries and roles'. ${ }^{104}$ Poe's story illustrates for him that 'everything that might be considered the stuff of psychology', a subject's identity, choices and even gender, are determined by the autonomous structure of the symbolic order. This structure can thus be conceived of as the subject's unconscious. ${ }^{105}$

Despite the difficulty of his work, Lacan's ideas are still widely used in literary criticism. Here I will focus on a well-known early example of Lacanian reading,

\footnotetext{
${ }^{100}$ Ibid. pp. $41-44$.

${ }^{101}$ Ibid. p. 58.

102 Ibid. p. 59.

${ }^{103}$ Ibid p. 60.

${ }^{104}$ Ibid

${ }^{105}$ Ibid. p. 65.
} 
Shoshana Felman's essay 'Turning the Screw of Interpretation' (1977). ${ }^{106}$ Henry James'story 'The Turn of the Screw' (1908) was analysed in Freudian terms in 1934 by Edmund Wilson, whose essay provoked debate about the validity of Freudian reading. Felman argues that such readings presume to "pull the answer out of its hiding place' in the text, that is, to explain the appearance of the text with the reality of the mental processes described by psychoanalysis. ${ }^{107}$ The questions raised by the text are answered in terms of sexuality. Felman objects to this kind of reading on the grounds that sexuality in Freud's thought is not simple. It is conceived as a 'conflict between two forces', desire and repression. ${ }^{108}$ Felman thus compares sexuality to rhetoric, since both are constituted by 'the coexistence of dynamically antagonistic meanings' ${ }^{109}$ She writes that sexuality is not the hidden meaning of the text, as in an orthodox Freudian reading, but rather that 'through which the text fails to mean' in a definite or unified way. ${ }^{110}$ Felman follows through Lacan's dictum that 'the unconscious is the discourse of the other'. She notes the prevalence of objects of interpretation in the story, letters, speeches and ghosts, and describes the action of the central character, the governess, as an attempt to reduce these ambiguities, to make sense of their possible senses. ${ }^{111}$ This also describes the reader's passage through the story, which the text can thus be said to anticipate or to contain. Felman compares this reading to the psychoanalyst's 'reading' of the unconscious of his patient through the latter's speech, as described by Lacan.

\footnotetext{
${ }^{106}$ In Psychoanalytic Literary Criticism (London and New York: Longman, 1994) p. 31, Maud Ellmann calls this essay 'one of the finest examples of psychoanalytic criticism to date'. In Psychoanalvtic Criticism (London: Routledge, 1984) p. 131, Elizabeth Wright calls it 'exemplary'.

${ }^{107}$ Shoshana Felman. 'Turning the Screw of Interpretation', Yale French Studies 55-56 (1977) p 105 .

${ }^{108}$ Ibid. p. 110.

${ }^{109}$ Ibid. p. 112.

${ }^{110}$ Ibid. It should be clear that she is as influenced by Paul de Man as by Lacan.
} 
She points out that the Freudian critic behaves like the story's central character in attempting to reduce its ambiguities to a definite meaning. Both thereby repress the unconscious in the text. Felman writes:

In seeking to 'explain' and master literature, in... killing...that which, within speech, is incapable of speaking,...the psychoanalytic reading...turns out to be a reading which represses the unconscious... which it purports to be 'explaining". ${ }^{112}$

The governess can be seen by a Freudian critic to repress the sexual desires that she has herself and perceives in other characters. The Freudian critic, on the other hand, can be seen to repress the polysemy of the text, which for Felman represents the structure of the unconscious. The Lacanian critic, she writes, is attentive to the 'incessant slippage... of the signifying chain from link to link' which is the reality of the text as the "discourse of the other'. 113

\section{Julia Kristeva}

Julia Kristeva (b. 1941) came from Bulgaria to Paris in 1965 on a doctoral scholarship, where she worked with many of the leading intellectual figures of the period, including Roland Barthes. She published widely in semiotics, with emphasis on works of avant-garde literature, and became professor of linguistics at the University of Paris VII in 1974. Under the influence of the linguist Émile Benveniste and of Lacan, Kristeva's work was increasingly influenced by psychoanalysis, and she set up practice as a psychoanalyst in $1979 .{ }^{114}$

\footnotetext{
111 Ibid. p. 155.

112 Ibid. p. 193.

113 Ibid.

114 See Ross Mitchell Guberman ed, Julia Kristeva: Interviews (New York: Columbia University Press, 1996) pp. 3-58 for further biographical information.
} 
In her lengthy doctoral thesis Revolution in Poetic Language (1974), Kristeva elaborates a psychoanalytic account of the process of literary signification and of its effects in society. She writes, 'The text is a practice that could be compared to political revolution; the one brings about in the subject what the other introduces in society'. 115 The problem with structuralist semiotics for Kristeva is that it does not account for the subject, except as a transcendental ego which performs the combinatory operations analysed by semiotics. If semiotics is to account for the split or 'decentred' subject of psychoanalysis, it must describe the conditions that produce the ego as the "subject of enunciation'. 116 Structuralism is a science of the symbolic order, but it does not account for the passage of the subject of language through the Oedipus complex into that order. ${ }^{117}$ In order to formulate a theory of language that accounts for the subject's history in this way, Kristeva argues that there are two modes of the signifying process, which she calls the semiotic' and 'the symbolic'.118 The semiotic mode derives from the pre-Oedipal organisation of the subject's drives or instincts. ${ }^{119}$ Kristeva borrows Plato's term for 'space', chora, to describe this organisation, which she conceives in the terms we have seen Freud use in the 'Project for a Scientific Psychology'. She writes:

Discrete quantities of energy move through the body of the subject... and... are arranged according to the various constraints imposed on this body... by family and social structures. ${ }^{120}$

\footnotetext{
115 Julia Kristeva. Revolution in Poetic Language, tr. Margaret Waller (New York: Columbia University Press, 1984) p. 17.

${ }^{116}$ Tbid. pp. 30. 36.

${ }^{117}$ See also 'The System and the Speaking Subject', Toril Moi, ed., The Kristeva Reader (Oxford: Blackwell, 1986) pp. 25-33.

${ }^{118}$ Kristeva, Revolution in Poetic Language p. 24

${ }^{119}$ Kristeva's translators render her term 'pulsion' as 'drive'. It translates Frend's term 'trieb', which the Standard Edition usually renders as 'instinct'.

${ }^{120}$ Ibid. p. 25.
} 
Before the ego begins to be formed in the mirror stage, the subject's experience is determined by the influxes of discharges of energy that Freud described in the 'Project'. Kristeva calls these 'drives and stases', and hypothesises a 'chora' which constitutes their 'essentially mobile and extremely provisional articulation'. ${ }^{121}$ In Plato's Timaeus, 'chora' refers to the space in which created things exist. ${ }^{122}$ It is neither of the order of eternal ideas nor of the order of their created images, but a third term necessary to conceive the relation between these two orders. It is an 'invisible and formless being which receives all things' ${ }^{123}$ Plato calls it 'the receptacle... of all generation' or becoming. ${ }^{124}$ Kristeva hypothesises an analogous space in the mind, in which the flux of drive and stasis takes place. Like Plato's space, the 'semiotic chora' is neither intelligible nor sensible, because it precedes the symbolic order in which anything can be predicated of it. Nevertheless, it is that from which the symbolic is produced. The flux of drive and stasis which constitutes it is expressed in the amorphous pre-Oedipal subject in sounds and gestures. It is ordered by the infant's relation to its mother's body, through which it experiences her educational procedures as a kind of mediation of the symbolic order in which she lives. The sounds and gestures are organised into loosely defined units of rhythm and intonation by the maternal organisation of the chora. Kristeva writes, 'Phonic..., kinetic or chromatic units and differences are the marks of [the] stases in the drives'. ${ }^{125}$

This vocal flux which characterises the semiotic mode Kristeva sees as a precursor to the symbolic mode, or the 'logico-syntactic articulation' of

\footnotetext{
${ }^{121}$ Tbid.

${ }^{122}$ Plato. Timaeus 49c-51b. Toril Moi's erroneous assertion that the word means 'enclosed space or womb' (The Kristeva Reader p. 12) can cause confusion. Whilst Plato likens the chora to a mother. the space he has in mind is not all cnclosed. but the open and indefinite space in which things exist and change.

${ }^{123}$ Timaeus 51a.
} 
language. ${ }^{126}$ Entry into language-use, however, demands the crucial step of 'establishing the identification of the subject and object as preconditions of propositionality'. ${ }^{127}$ The infant, that is, needs to develop an ' $\mathrm{I}$ ', a sense of himself as an independent entity in a world composed of similar entities. Kristeva follows Lacan in tracing the beginning of this process to the mirror stage and finding its completion in the 'discovery of castration' by which the Oedipus complex is dissolved. Only in this way can he assume the subject position demanded by language and form propositions about objects. This 'rupture' with the amorphous pre-Oedipal relation to the mother Kristeva calls the 'thetic phase', from the Greek word for 'position', because the subject begins to assume his part in the positional structure effected by language in order to articulate conceptual positions. ${ }^{128}$ She writes, 'The thetic posits the signifiable object: it posits signification as both a denotation (of an object) and an enunciation (of a displaced subject) ${ }^{129}$ This phase, that of language-learning, constitutes 'an acute...confrontation between positing-separating-identifying and the motility of the semiotic chora'. ${ }^{130}$ It leads the child into the 'symbolic' mode of language, that is, the symbolic order as conceived by Lacan. Kristeva writes, 'Symbolic would seem an appropriate term for this always split unification that is produced by a rupture', since the word's etymology connotes two split parts joined to form a token. ${ }^{131}$

The signifying process, once the subject has passed into the symbolic order, consists of a constant struggle between its semiotic and symbolic modes.

\footnotetext{
${ }^{124}$ Ibid. 49a.

${ }^{125}$ Kristeva. Revolution in Poetic Language p. 28.

${ }^{126}$ Ibid. p. 62.

${ }^{127}$ Ibid. p. 43 .

${ }^{128}$ Ibid.

${ }^{129}$ Ibid. p. 54.
} 
Kristeva writes, "Although originally a precondition of the symbolic, the semiotic functions within signifying practices as the result of a transgression of the symbolic' ${ }^{132}$ The semiotic, the unconscious of language, tends to irrupt in it like a symptom. This, for Kristeva, occurs more in certain types of language than others, and is most pronounced in poetic language. The function of poetic language, she writes, is 'to introduce through the symbolic that which works on, moves through and threatens it' ${ }^{133}$ Kristeva's concept of the symbolic, like Lacan's, includes every kind of systematic regulation of individual satisfaction in society, such as law, religion and political structures. With Lévi-Strauss in mind, she writes:

Social anthropology reconfirms [the] equivalence between the symbolic and the social when it considers society's various means of selfregulation... as languages. ${ }^{134}$

Kristeva calls the archaic individual satisfaction repressed by the symbolic order 'jouissance', which term denotes intense pleasure and connotes both loss of self and orgasm. ${ }^{135}$ What occurs in art, she writes, is that

in cracking the socio-symbolic order, splitting it open, changing vocabulary and syntax, the word itself and releasing from beneath them the drives borne by vocalic or kinetic differences, jouissance works its way into the social and symbolic. ${ }^{136}$

Poetry is the enactment in language of this infiltration of jouissance into the symbolic. In 'From One Identity to an Other' (1975), Kristeva writes, 'Poetic language... would be the equivalent of incest' from the perspective of law. ${ }^{137}$ The social effect of this kind of language, Kristeva writes, is that it '[disturbs] the

\footnotetext{
${ }^{130}$ Ibid. p. 47.

${ }^{131}$ Ibid. p. 49

${ }^{132}$ Ibid. p. 68

${ }^{133}$ Ibid. p. 81.

${ }^{134}$ Ibid. p. 72

${ }_{135}^{135}$ See John Lechte, Julia Kristeva (London and New York: Routledge, 1990) p. 67.

${ }^{136}$ Kristeva, op. cit. p. 80.

${ }^{137}$ Kristeva. Desire in Language: A Semiotic Approach to Literature and Art, ed. Leon Roudiez (Oxford: Blackwell, 1980) p. 136.
} 
logic that dominated the social order [of an era]...through that logic itself, by assuming and unravelling its position, its syntheses and hence the ideologies it controls. ${ }^{2}{ }^{138}$

In the second part of Revolution in Poetic Language, Kristeva analyses the semiotic mode perceptible in the poetic texts of Stephane Mallarmé and the Comte de Lautréamont. She calls this semiotic process the 'genotext', that is, the text considered in terms of its generation, as opposed to the 'phenotext', the finished product as it appears and is exchanged in the symbolic order. ${ }^{139}$ In Mallarmé's poem 'Prose', Kristeva points out the accumulation of groups of phonemes, or units of sound, in certain lines and their repetition in certain stanzas. They constitute a 'phonic insistence [which] establishes itself as the predominant organisational principle in the text, almost effacing the underlying metric processes' ${ }^{140}$ Kristeva compares this 'phonetic' organisation of the text, which underlies its semantic and syntactic organisation, to the utterance of infants who produce all possible sounds before they learn the limited set of them which constitute their national language. Each of the phonemes brings with it a 'semantic constellation' derived from its association with all the other words and forms in which it appears. ${ }^{141}$ These phonemic groups constitute a 'network of semantic values which are not necessarily those of the morphemes [units of form] and lexemes [units of vocabulary] given in the phenotext ${ }^{0}{ }^{142}$ Kristeva relates the infant's production of sounds and gradual awareness of their difference to the drive activity which animates him. She finds that the first pair

\footnotetext{
${ }^{138}$ Kristeva, Revolution in Poetic Language p. 83.

${ }^{139}$ Ibid. pp. 86-88.

${ }^{140}$ Kristeva, La Rérolution du Langage Poétique (Paris: Seuil, 1974) p. 221. Citations from this work are in my translation.

${ }^{141}$ Ibid. p. 222.

${ }^{142}$ Ibid.
} 
of phonemes, the labial nasal liquid $/ \mathrm{m} /$ of 'mama' and the labial explosive $/ \mathrm{p} /$ of 'papa', 'translate suction and explosion,...[or] incorporative orality and destructive anality, into articulation'. ${ }^{143}$ In a similar way, she attributes a series of phonemes to a series of drives, assigning the liquids (1), (m) and (n) and the closed front vowels to the oral drive, the open back vowels to the anal drive, and the apical (r) (as in the French 'rien') to the phallic drive. ${ }^{144}$ So in the first stanza of Mallarmé's 'Prose', Kristeva traces two series of phonemes, one of which articulates aggressive phallic and anal drives $(/ \mathrm{tR} /, / \mathrm{dR} / / \mathrm{f} /$; and $/ \mathrm{gR} /$ respectively) and the other the incorporative oral drive $(/ \mathrm{m} /)$. She notes that the group $/ \mathrm{tR} /$ is semantically overdetermined by its occurrence in other lines of Mallarmé's that denote rupture or birth. ${ }^{145}$ In this way, she traces in detail the play of drives that underlies the symbolic organisation of the poem, inscribed in the physical qualities of its sounds.

In her later works, Kristeva reads literary texts as examples of certain psychic orientations. In Powers of Horror (1980), she describes the mechanism of 'abjection', or the pre-symbolic rejection of the mother which leads to a sense of disgust, and she reads the work of Louis-Ferdinand Céline in terms of this process. She argues that 'Céline's narrative is a narrative of suffering and horror... because his whole narrative stance seems controlled by the necessity of going through abjection' ${ }^{146}$ In Tales of Love (1983), she offers a psychoanalytic

\footnotetext{
${ }^{143}$ Ibid. p. 225.

${ }^{144}$ Ibid.

${ }^{145}$ Ibid. p. 244.

146 Kristeva, Powers of Horror: An Essay on Abjection, tr. Leon S. Roudiez (New York: Columbia University Press, 1982) p. 141.
} 
account of love, and explains a series of literary works in the terms of this account. $^{147}$

\section{(ii) Psychoanalysis and Christianity}

In order to assess the value of these theories for Christian literary theory, I will examine some of the relations between psychoanalysis and Christian theology. For Freud, the scientific world-view in which psychoanalysis was conceived prohibited assent to religious doctrines. ${ }^{148}$ In this section, I will ask whether this assertion is justified. I will examine some psychoanalytic interpretations of Christianity and some Christian interpretations of psychoanalysis, in order to establish the degree to which Christian literary theory can or should use the methodologies of psychoanalytic literary theory.

\section{Freud on Religion}

I will begin with an analysis of Freud's views on religion. In Totem and Taboo (1912), he offers a genetic account of religious rites, comparing the primitive phenomenon of taboo, in which objects and people are extremely venerated and so considered untouchable, to the symptoms of obsessional neurosis. Psychoanalysts, he writes, are in frequent contact with 'people who have created for themselves individual taboo prohibitions... and who obey them just as strictly

\footnotetext{
${ }^{147}$ Kristeva. Tales of Love, tr. Leon S. Roudiez (New York: Columbia University Press, 1985) pp. 209-233, 280-296, 318-331.

${ }_{48}$ See 'The Question of a Weltanschauung', PFL 2 pp. 193-219.
} 
as savages obey [their] communal taboos'.149 They call them obsessional neurotics. Freud summarises the similarities between the prohibitions involved in this kind of neurosis and those involved in taboo: neither has an apparent motive, both carry a strong sense of obligation, both can easily be displaced onto different objects by a kind of 'infection', and both give rise to the performance of ceremonial acts. ${ }^{150}$ Psychoanalysis explains obsessional symptoms as the result of a repressed instinct, typically concerning touching. An obsessional neurotic has a strong unconscious wish for something, and a correspondingly strong conscious disgust for its fulfilment. Freud calls this object-relation 'ambivalent'. ${ }^{151}$ The tension caused by this conflict is discharged in a ramifying series of obsessive practices that approach increasingly closely in sense to the originally prohibited activity. Freud applies this diagnosis to the corresponding phenomena of taboo which, he writes, must derive from a series of ancient prohibitions placed upon a generation by its ancestors. 'These prohibitions must have concerned activities towards which there was a strong inclination'. ${ }^{152}$ Given that the taboos still persist among primitive peoples, the original desire must also persist. Freud concludes, 'The basis of taboo is a prohibited action, for performing which a strong inclination exists in the unconscious". ${ }^{153}$

In his essay on totemism, the primitive religious system in which clans are identified by an animal or object which they regard as an ancestor, Freud established that the strongest taboo prohibitions were the two laws not to kill the totem animal and to avoid sexual intercourse with members of the same totem clan. He cites his case-study of 'Little Hans' and a case of child analysis

\footnotetext{
${ }^{149}$ PFL 13 p. 79.

${ }^{150}$ Ibid. p. 82.

151 Ibid. p. 83

${ }^{152}$ Ibid. p. 85.
} 
published by Sándor Ferenczi, in which children are seen to display attitudes to an animal comparable to primitive attitudes towards totem animals. These are identification with the animal and ambivalent emotions towards it. Since these are the relations in which men stand to their fathers, according to psychoanalysis, Freud hypothesises that the totem animal represents the father. It follows from this that the taboos against killing the animal and sexual relations within the totem clan 'coincide... with the two primal wishes of children' which constitute the Oedipus complex, murder of the father and sexual relations with the mother. ${ }^{154}$ It is probable, Freud concludes, that 'the totemic system...was a product of the conditions involved in the Oedipus complex ${ }^{2}{ }^{155}$ He goes on to consider the primitive rites in which the totem animal or a representative of it is sacrificed and eaten by the community in a ceremonial meal. He combines these facts with Charles Darwin's hypothesis in The Descent of Man (1871) of the 'primal horde', that is, that the earliest human societies comprised groups made up of an aggressive father who kept all the females to himself and jealously drove away the sons. From these data Freud tentatively elaborates an account of the origin of religion. ${ }^{156}$ There came a time when the expelled sons came together and killed the father of the primal horde. Since they were savages they ate their victim. The totem meal represents a joyful commemoration of this ancient crime. As with all sons, the brothers had an ambivalent complex of emotions towards their father, both loving him and hating him, and later felt remorse for their crime. In the process Freud calls 'deferred obedience' they attempted to atone for their crime by forbidding the killing of the totem animal,

\footnotetext{
153 Ibid. p. 86.

${ }^{154}$ Ibid. p. 192.

155 Ibid. pp. 192-193.

${ }^{156}$ Ibid. pp. 203-208.
} 
the representative of the father, and by resigning their claim to the women set free for them by their parricide. The two fundamental taboos of totemism thus arose as a means of allaying the guilt aroused by this ancient crime.

Freud goes on to hypothesise that 'all later religions are... attempts at solving the same problem'. ${ }^{157}$ Throughout the development of religion from totemism to monotheism, according to Freud, 'God is nothing other than an exalted father' ${ }^{158}$ He sees the same Oedipal complex of attitudes to the father at work in Christianity. Christ sacrificed himself, and so redeemed the company of brothers (the Christian community) from their original sin. This sin, since it required a death for its atonement, must itself have been a murder. Since the original sin in Christian theology, according to Freud, was one against God the Father, it must have been a murder of the father. He writes:

In the Christian doctrine...men were acknowledging in the most undisguised manner the guilty primeval deed, since they found the fullest atonement for it in the sacrifice of this one son. ${ }^{159}$

Their rebellious emotions towards the father find expression in the displacement of a religion of the father by a religion of the son, Freud goes on. In communion, the brothers eat and identify with the son just as the totem animal is eaten and identified with in totemism. In Moses and Monotheism (1939), Freud applies his theory to Judaism. He argues that the God represented by Moses was revered as a father. ${ }^{160}$ Although hostility towards him was largely repressed, the strictness of the Jewish Law, Freud writes, derives from 'the sense of guilt felt on account of a suppressed hostility to God'. 161

\footnotetext{
${ }^{157}$ Ibid. p. 206.

158 Ibid. p. 209.

159 Ibid. p. 216.

${ }^{160}$ Tbid. pp. 356-370.

161 Ibid. p. 384.
} 
In The Future of an Illusion (1927), Freud discusses the value of religious ideas in civilisation. He defines religious ideas as those not arrived at by empirical observation and inference but which nevertheless lay claim to our belief. Whilst they are the most potentially useful concepts that civilisation provides, he writes, religious ideas are also the least well authenticated. Freud accounts for their persistence by suggesting that they are 'illusions, fulfilments of the oldest, strongest and most urgent wishes of mankind'. ${ }^{162}$ By an illusion, he means an imaginary wish-fulfilment. The wishes from which religion arises, according to Freud, derive from the experience of helplessness both of each individual in his early infancy and of the human race in its early stages of development. He writes, 'A store of ideas is created, born from man's need to make his helplessness tolerable' ${ }^{163}$ Civilisation is constructed as a means of defending man from the superior power of nature and the indifference of fate. Religious ideas develop, according to Freud, as a part of this process of civilisation. Primitive man tries to overcome his helplessness with respect to natural forces by peopling the world with anthropomorphic spirits and relating to them in religious rites. Human helplessness in the face of nature recalls each individual's helplessness as an infant, when he feared his father but also hoped for and experienced his protection. So primitive men gave their deities the ambivalent character of a father. As religious ideas develop to keep pace with natural science, Freud writes, 'man's helplessness remains, and along with it his longing for his father and the gods'. ${ }^{164}$ Judaism eventually allowed men to relate to God precisely as to a father, and was followed in this by Christianity. As in Totem and Taboo, Freud concludes that religion is something like 'the universal

\footnotetext{
${ }^{162}$ SE XXI p. 30.

${ }^{163}$ Ibid. p. 18.
} 
obsessional neurosis of humanity...[which] arose out of the Oedipus complex' ${ }^{365}$ We project onto God the precepts of morality that are in fact the result of the process of civilisation, in which the pleasure principle is renounced in favour of the reality principle. In Freud's view, science has brought humanity to the point where it is time to mature from the infantile religious attitude, and 'honestly admit the purely human origin of all the...precepts of civilisation' 166 In this way, people could understand that these precepts were made to serve them rather than to rule them.

\section{An Assessment of Freud's Atheism}

It is difficult to take the genetic account of Christianity that Freud gives in Totem and Taboo seriously. It looks like unsubstantiated mythology and that is on the whole what it is. As A.L. Kroeber writes in his review of Totem and Taboo, 'The mere extrication and presentation of the... hypothesis... is probably sufficient to prevent its acceptance'. ${ }^{167}$ We should note first of all that Freud's texts on religion contain many qualifications and acknowledgements of the speculative nature of their assertions. The argument for the development of religion from an Oedipal complex of emotions enacted in an ancient parricide depends on the identification of the totem animal with the father, which is based on two case studies of neurotic children. Freud does not tell us whether these children's displacement of their attitudes towards their fathers onto animals is typical, and it is difficult to believe that this is the case on the basis of only two

\footnotetext{
${ }^{164}$ Ibid.

165 Ibid. p. 43.

${ }^{166}$ Ibid. p. 41.
} 
studies. This is especially true since in one of the cases, the boy's 'totemic interests did not arise in direct relation with the Oedipus complex but on the basis of its...precondition, the castration complex' ${ }^{168}$ Freud writes of his identification of the totem animal with the father that it leads to his conclusions, 'if this equation is anything more than a misleading trick of chance'. ${ }^{169} \mathrm{He}$ merely asserts as a result that it is 'probable' that totemism is a product of the Oedipus complex. ${ }^{170}$ But even this is an overstatement if the premise on which it is based has no more support than Freud has described. As for the myth of the primal horde from which he derives religion, Freud writes:

The lack of precision in what I have written... may be attributed to the reserve necessitated by the nature of the topic. It would be as foolish to aim at exactitude... as it would be unfair to insist upon certainty. ${ }^{171}$

Freud points out at various points in his argument some of the inadequacies that force themselves upon him. He acknowledges that in deriving religion from a father-complex he cannot account for the development of mother-goddesses, whose worship may have preceded that of father-gods. ${ }^{172}$ His explanation of the Christian eucharist is awkward. Whilst describing Christianity as a son-religion that displaces the father-religion, and acknowledging that the Christian meal is a consumption of the son, Freud nevertheless asserts, 'The Christian communion, however, is essentially a fresh elimination of the father', like a totem meal. ${ }^{173}$ Freud gives no explanation for this transition from eating the son (which is what happens) to eating the father (which supports his argument). We can accept his

\footnotetext{
${ }^{167}$ A.L. Kroeber, The Nature of Culture (Chicago and London: University of Chicago Press, 1952) p. 302.

${ }^{168} \mathrm{PFL}, 13 \mathrm{p}$. 190. We might add that it is difficult to describe the castration complex as the 'precondition' of the Oedipus complex in boys, since Freud usually describes the former as a result of the latter.

${ }_{169}^{16}$ Ibid. p. 192.

${ }^{170}$ Ibid.

${ }^{171}$ Ibid. p. 204.

172 Ibid. p. 211.
} 
citation from J.G. Frazer, that the Christian communion represents an absorption of a pre-Christian ritual, but not Freud's own assertion that it represents consumption of a father. When Freud comes to discuss the phylogenetic assumptions that underlie his hypotheses, he writes, 'It must be admitted that these are grave difficulties... Any explanation that could avoid presumption of such a kind would seem to be preferable'. ${ }^{174}$ There is no doubt that Freud's confession of presumption is justified with respect to his method of argument. Unsupported speculation underlies many of the fundamental theses of Totem and Taboo. As a result, whilst it is compelling for its imaginative quality, we cannot accept it as a true account of the origin of religion.

We should also note that anthropology and history of religion have not accepted Freud's arguments. Concerning Freud's account of the primal horde, which he constructed from Darwin and J.J. Atkinson, the anthropologist A.L. Kroeber writes, "The Darwin-Atkinson supposition is only hypothetical'. ${ }^{175}$ 'It is a mere guess', he writes, that the earliest organisation of human society was so organised. ${ }^{176}$ Lévi-Strauss, who is sympathetic to psychoanalysis, nevertheless writes of 'the gratuitousness of the hypothesis of the male horde and of primitive murder', which makes Totem and Taboo anthropologically unacceptable. ${ }^{177}$ It constitutes a vicious circle, deriving the social state from events that presuppose it. Lévi-Strauss writes, 'The desire for the mother or the sister, the murder of the father and the sons' repentance, undoubtedly do not

\footnotetext{
${ }^{173}$ Ibid. p. 217.

174 Ibid. p. 220.

${ }^{175}$ Kroeber, The Nature of Culture p. 302.

${ }^{176} \mathrm{Ibid}$.

${ }^{177}$ Lévi-Strauss, The Elementary Structures of Kinship p. 491.
} 
correspond to any facts or group of facts occupying a given place in history' ${ }^{178}$ The importance Freud attaches to the totem meal is based on W. Robertson Smith's assertion that sacrifice was the essential feature of primitive religion. ${ }^{179}$ Kroeber writes:

Robertson Smith's allegation that blood sacrifice is central in ancient cult holds chiefly for the Mediterraneanoid culture of a certain period... It does not apply to regions outside the sphere of affection by these cultures. $^{180}$

In his book Anthroplogy (1923), Kroeber traced the development of religion among the Californian Indians. The earliest rites he found there were a girls' adolescence rite and a victory dance, which contradicts Freud's premise that the totem meal is the earliest and basic religious rite. ${ }^{181}$ In Structure and Function in Primitive Society (1952), the anthropologist A.R. Radcliffe-Brown writes of the diversity of totemic rites, and of the impossibility of assigning a single origin to them. He asserts, 'It is clear that the very diverse forms of totemism that exist all over the world must have had very diverse origins'. ${ }^{182}$ Any thesis such as Freud's which attempts to speak of an origin of totemism must assume that all its diverse forms are modifications of a single form. Radcliffe-Brown writes, "There does not seem... to be a particle of evidence to justify such an assumption' ${ }^{183}$ Even if one makes it, he continues, the resulting assertions of what this original form of totemism was, how the existing forms were produced from it, and how it came into existence itself, can be no more than speculation. He writes, 'Such

\footnotetext{
${ }^{178}$ Ibid. Lévi-Strauss also objects to Freud's equation of ontogenesis and phylogenesis. He writes. 'The most primitive culture is still as adult culture, and as such is incompatible with infantile manifestations even in the most highly developed civilisation (ibid p. 92).

${ }^{179}$ PFL 13 p. 193.

${ }^{180}$ Kroeber. The Nature of Culture p. 302.

181 A.L. Kroeber, Anthropology (London: Harrap, 1923) pp. 300-316.

182 A.R. Radcliffe-Brown, Structure and Function in Primitive Societv: Essays and Addresses (New York and London: The Free Press, 1952) p. 122.
} 
speculations, being for ever incapable of inductive verification, can... have no value for a science of culture'. ${ }^{184}$ Radcliffe-Brown asserts that religious rites are symbolic expressions that regulate and perpetuate the sentiments on which the constitution of a given society depends. Religions therefore vary according to the structure of the society in which they function. ${ }^{185}$ To account for totemism, and $a$ fortiori religion in general, in terms of a universal phylogenetic heritage, as Freud did, is for Radcliffe-Brown simply a category mistake.

We should also note that Freud admits that his psychoanalytic account of religion is not exhaustive but rather contributes to an understanding of one of its many determinants. He writes:

If psychoanalysis is compelled... to lay all the emphasis on one particular source [of religion], that does not mean it is claiming either that that source is the only one or that it occupies first place [among the many sources]. ${ }^{186}$

He points out that in designating religious ideas as illusions he is not concerned with their truth but only with their 'psychological nature'. ${ }^{187} \mathrm{He}$ writes, 'To assess the truth-value of religious doctrines does not lie within the scope of the present enquiry'. ${ }^{188} \mathrm{He}$ adds that the analogy he draws between religious and infantile attitudes 'does not... exhaust the essential nature of religion'. ${ }^{189} \mathrm{He}$ is right to make these qualifications, since the thesis that religious ideas are wishfulfilments does not entail a conclusion about their truth-value. Freud's hypothesis that we project onto God our infantile and inherited attitudes to our

\footnotetext{
${ }^{183}$ Ibid. In Freud and the Problem of God (New Haven: Yale University Press, 1979) p. 67, Hans Küng writes that the claim that any form of religion was everywhere original is 'a dogmatic postulate, not a historically proved fact'.

${ }_{184}$ Radcliffe-Brown. Structure and Function. p. 122.

185 Ibid. pp. 157-161.

${ }^{186}$ PFL 13 p. 159.

187 SE XXI p. 33.

188 Tbid.

${ }^{189}$ Ibid. p. 43. See Freud's letter to Oskar Pfister of 9 February 1909, in which he writes, "In itself psychoanalysis is neither religious nor irreligious but an impartial tool'. Psychoanalvsis and
} 
fathers is indebted to Feuerbach's projection theory, which we have seen also influenced Marx. ${ }^{190}$ In Freud and the Problem of God (1979), Hans Küng argues that Freud's illusion-theory must be judged in the same way as Feuerbach's projection-theory, as 'a hypothesis which has not been conclusively proved' 191 No doubt religion can be an expression of neurotic regression to infantile attitudes, as Freud asserts, but it does not follow from this that this is always the case. No doubt belief in God is structured by a child's attitude to its parents, but it does not follow from this that God has no independent existence. As Küng writes, 'A real God may certainly correspond to the wish for God'. ${ }^{192}$ The case cannot be proved either way.

Freud's critique of religion in The Future of an Illusion nevertheless has its value. His comparison of religious practices with obsessional neurosis can be taken as a description of the ease with which such practices can slip into automatic and meaningless rituals which do not contribute to a deeper relation with God but are motivated by fear or by guilt. Freud's comment that religious people have 'always known how to externalise the precepts of religion and thus to nullify their intentions' is also fair. ${ }^{193} \mathrm{He}$ is right to assert that religion can be a means of avoiding a responsible moral life rather than an incentive or encouragement to one. His wish-fulfilment theory similarly reflects the fact that religion can degenerate into a means of avoiding an encounter with the

Faith: The Letters of Sigmund Freud and Oskar Pfister, ed. Heinrich Meng and Enst L. Freud (London: Hogarth, 1962) p. 17.

${ }^{190}$ See Ralph D. Wood, "Psychoanalysis and Fundamentalism: A Lesson from Feminist Critiques of Freud', in Janet Liebman Jacobs and Donald Capps, eds., Religion, Society and Psychoanalvsis (Boulder, CO: Westview, 1997) p. 59. In 'Christianity and Psychoanalysis Part I: Jesus as the Anti-Oedipus', Journal of Psychology and Theology 12 (1984), Paul C. Vitz and John Gartner write that Freud read Feuerbach avidly in his youth (p. 12). In The Essence of Christianity, tr. from the German, (New York: Harper, 1957) p. 33, Feuerebach argues that 'in religion man contemplates his own nature'.

${ }_{191}^{191}$ Küng, Freud and the Problem of God p. 76.

192 Ibid. p. 78. 
transcendent reality of God rather than constituting such an encounter. Freud's critique of potential psychological over-simplicity in theological concepts reminds Christian theology of the complexity of the psyche for which it must account.

It is clear, however, that Freud's theories are not as incompatible with religion as he himself asserts. His argument that certain Christian doctrines have their origin in an ancient parricide is no more than speculation, and has been rejected as such by anthropology. His thesis that totemism is the original form of religion has also been rejected, upon which his account of the Oedipus complex as the source of religion depended. His wish-fulfilment theory has no implication for the question of the existence of God, but provides an ethical critique of certain degenerate forms of religion. There is nothing in Freud's studies on religion that presents a serious obstacle to Christian belief, and the last point constitutes a certain amount of shared ground with it. What this means for Christian literary theory is that Freud's thought on religion does not prevent us from using psychoanalytic critical methodology when it seems appropriate to do so.

\section{Jung and Fromm on Religion}

It is well known that Freud's atheism was not shared by many other psychoanalysts. Carl Gustav Jung (1875-1961) points out that Freud's illusion theory is "based on the rationalistic materialism of the scientific views current in the late nineteenth century'. ${ }^{194}$ In Psychology and Religion (1938), Jung argues that God is a psychological reality. He defines a religious event in accordance

\footnotetext{
${ }^{193}$ SE XXI p. 37.
} 
with Rudolf Otto's concept of the 'numinous', that is, as 'a dynamic existence or effect not caused by an arbitrary act of will'. ${ }^{195}$ For Jung religion denotes 'the attitude peculiar to a consciousness which has been altered by the experience of the numinosum'. ${ }^{196}$ On this definition, experiences that proceed from the unconscious can be called religious. Jung's unconscious is not the seat of repressed instincts, as Freud conceives it, but 'an illimitable and indefinable addition to every personality' ${ }^{197}$ For Jung, an individual's personality consists of a more or less definable conscious part and an unconscious part about which we only know what we must infer to explain certain psychological facts that cannot be attributed to consciousness. Certain dreams that Jung analyses contain clear and authoritative voices that on waking have the force of an intuition. 'They... contain a superior analysis or insight which consciousness has not been able to produce'. ${ }^{198}$ For Jung these constitute an 'immediate experience' of the numinous, that is, of an unknown factor that impinges upon consciousness from without. Hence he calls them a 'basic religious phenomenon'. 199

Certain Christian dogmas, such as those of the Incarnation, the Trinity and the Virgin Birth, Jung sees as such articulations of the unconscious. They appear so frequently in analysis and in the history of religions that he concludes that they also come to the consciousness of individuals and groups from another source than conscious decision. He writes, 'The dogma is like a dream, reflecting the spontaneous and autonomous activity of the objective psyche, the

\footnotetext{
${ }^{194} \mathrm{Jung}$, 'Psychoanalysis and the Cure of Souls', Collected Works' Vol. 11, tr. R.F.C. Hull (London: Routledge and Kegan Paul, 1958) p. 349.

195 Jung, Psychology and Religion (New Haven: Yale University Press, 1938) p. 4.

196 Ibid. p. 6.

${ }^{197}$ Ibid. p. 47.

198 Ibid. p. 149.

${ }^{199}$ Tbid. p. 46.
} 
unconscious ${ }^{2}{ }^{200}$ Jung's unconscious contains collective material as well as individual, whose existence he induces from the repeated occurrence of certain motifs in the mythology and folklore of different peoples. He calls these motifs 'archetypes' and defines them as 'forms or images of a collective nature which occur practically all over the earth as constituents of myths and at the same time as autochthonous, individual products of unconscious origin'. ${ }^{201} \mathrm{He}$ finds that symbols of quaternity are archetypes of 'a world-creating deity'. ${ }^{202}$ This is particularly the case when the number four is combined with the circle form, such as in a quartered circle. Jung supports this assertion by a series of references to ancient and medieval philosophy and theology. God's unity and infinity are symbolised by the circle, and the four elements of creation by the quaternity. Jung writes, 'The four symbolises the parts, qualities and aspects of the One,...a more or less direct representation of the God manifested in his creation'. ${ }^{203}$ These comparisons, Jung writes, 'prove the existence of an archetypal image of the Deity', whose frequency makes its existence 'a noteworthy fact for any theologia naturalis ${ }^{204}$ The most complete form of this symbol in Jung's experience is the mandala, a Buddhist symbol of the universe, typically composed of a series of concentric circles surrounding a series of squares. In analysis, Jung found that production of this symbol expressed a feeling of harmony. He writes that it represents an experience of wholeness, of reconciliation of the conscious personality with the unconscious. ${ }^{205}$ Before the existence of God was doubted, according to Jung, man would project

\footnotetext{
${ }^{200}$ Ibid. p. 57.

201 Ibid. p. 63.

202 Tbid. p. 71.

${ }^{203}$ Ibid. pp. $71-72$.

204 lbid. p. 73 .

${ }^{205}$ Ibid. p. 99.
} 
unconscious experience onto the gods. Nowadays, if he is to achieve mental stability, he must recognise these experiences as part of a greater seif than that of which he is conscious. The mandala symbolises this recognition and hence 'the transformation of man into a divine being, ${ }^{206}$ For Jung, religion proved very often to be a necessity for this kind of internal integration, upon which he saw mental health to depend. In 'Psychotherapists or the Clergy' (1932), he writes:

Every one [of my patients over thirty-five] fell ill because he had lost what the living religions...have given to their followers, and none of them has been really healed who did not regain his religious outlook. ${ }^{207}$

Jung does not directly contradict Freud's thesis that no independently existent reality corresponds to our religious ideas. He asserts primarily that these ideas correspond to a psychic reality. He does not see this kind of explanation as reductive, however. In 'Transformation Symbolism in the Mass' (1954), he writes:

The modern psychologist is aware that he can produce no more than a description... of a psychic process whose real nature transcends consciousness just as much as does the mystery of life or of matter. At no point has he explained the mystery itself. ${ }^{208}$

Jung remained a Christian to the end of his life, although he thought that Christianity lacked a proper explanation of the unconscious. ${ }^{209}$ He makes no judgement on the independent existence of God, since he regards such a judgement to lie outside the field of psychology, but he clearly asserts that his own branch of psychology acknowledges that such existence is possible. It is certainly a psychic reality, acceptance of which in religious belief leads to increased mental well-being, and for some may be a necessary condition of such well-being. In Jung's thought, psychoanalysis neither contradicts the doctrines of

\footnotetext{
${ }^{206}$ Tbid. p. 112.

${ }^{207}$ Jung, 'Psychotherapists or the Clergy', Collected Works Vol. 11 p. 334

208 'Transformation Symbolism in the Mass', Collected Works Vol. 11 p. 296.
} 
Christianity nor implies that assent to them is a psychic delusion whose reality is to be explained by psychoanalysis.

Erich Fromm (1900-1980) criticises what he sees as Jung's exclusively psychological perspective on religion. In Psychoanalysis and Religion (1951), he attempts to widen the scope of the question by considering the social dimension of the psychology of religion. He defines religion as 'any system of thought and action shared by a group which gives the individual a frame of orientation and an object of devotion'. ${ }^{210}$ On this definition, every person needs religion to help him solve the inescapable problem of his existence and to achieve some degree of synthesis of his conflicting energies into a mature social life. There is no-one without religion, according to Fromm. The question is only to which kind of religion a person adheres. Man 'has only the choice of better or worse,,.. satisfactory or destructive forms of religions', ${ }^{211}$ Fromm discusses several modern religions, such as devotion to a state or to a company, but finds that the basic distinction to be drawn is that between 'authoritarian' and 'humanistic' religions. ${ }^{212}$ The former constitutes essentially 'surrender to a power transcending man' which has the right to demand his obedience. ${ }^{213}$ Calvinism and totalitarianism are examples of this kind of system. Humanistic religion, on the other hand, is based on 'man and his strength... his relationship to his fellow men and his position in the universe' ${ }^{214}$ Its goal is self-realisation rather than obedience. Fromm counts the teachings of Jesus, Socrates, Buddha and Spinoza among this kind of system. He sees church history as a conflict

\footnotetext{
${ }^{209}$ See Letters of C. G. Jung, ed. Gerhard Adler and Aniela Jaffé, Vol. 2 (London: Routledge. 1976) p. 575 .

${ }^{210}$ Erich Fromm, Psychoanalysis and Religion (London: Victor Gollancz, 1951) p. 29.

211 Ibid. p. 36

212 Tbid. p. 42

${ }^{213}$ Ibid. p. 43 .
} 
between the two principles. Psychoanalysis is concerned with the 'human reality' underlying religious formulations and practices, according to Fromm. In the humanistic religions this is 'the striving for love, truth and justice', and in the authoritarian religions 'submission to power, lack of love and of respect for the individual'. ${ }^{215}$

Fromm writes that psychoanalytic therapy has two interdependent functions, that of leading the patient to increased social adjustment and that of leading him to greater self-realisation. He writes that the latter, which he describes as 'cure of the soul', has 'very definitely a religious function'. ${ }^{216} \mathrm{He}$ finds that there is 'a core of ideas and norms' shared by the humanistic religions, and that psychoanalytic therapy aims to achieve precisely the attitude they describe. ${ }^{217}$ Humanistic religions assert that man must seek the truth about himself and his place in the world. Fromm writes that 'the psychoanalytic process is... a search for truth' also, that of an individual's internal sources of motivation. ${ }^{218}$ Fromm continues that psychoanalysis follows humanist-religious thought in linking an individual's search for truth with his attainment of freedom and independence. Fromm thinks that Freud's thought must be "[translated]... from the sphere of sex into that of interpersonal relations'. ${ }^{219}$ Where Freud speaks of incestuous instincts, that is, Fromm sees 'the more profound and fundamental desire' to remain a child, attached to protective figures whose prototype is the mother. It is this infantile attitude from which psychoanalysis helps an individual to mature into a morally responsible agent, he writes. In this it agrees with the teaching of

\footnotetext{
214 Ibid. p. 44.

215 Ibid. p. 70 .

216 Ibid. p. 81 .

217 Ibid. p. 82 .

218 Ibid. p. 83.

${ }^{219}$ Ibid. p. 85 .
} 
humanist religions that man must free himself from 'incestuous' orientations towards gratification and find his humanity in independent moral action. Fromm adds that psychoanalysis follows these religions in asserting that this action is primarily love. He writes, 'Analytic therapy is essentially an attempt to help the patient gain or regain his capacity for love'. ${ }^{220} \mathrm{He}$ concludes, 'The psychoanalytic cure of the soul aims at helping the patient to achieve an attitude which can be called religious in the humanistic... sense'. ${ }^{221}$

Like Jung, Fromm makes no judgement concerning the independent existence of God. But as with Jung, he asserts that psychoanalysis is not opposed to religious belief. It is neither false nor harmful, as Freud had argued. On the contrary, in Fromm's thought, Christian belief can be a way to achieve the personally and socially valuable mental orientation which is the goal of psychoanalysis. For Fromm, analytic therapy and Christianity share similar moral goals. In my examination of Freud's critique of religion I argued that psychoanalysis does not imply a denial of the truth-content of Christian doctrine, as Freud suggested. The thought of Jung and Fromm shows that, as it developed, various forms of psychoanalysis ceased to assert even that this was the case. The psychoanalytic accounts of religion mean that there is no inconsistency in Christian criticism using the methods of psychoanalytic theory if they should seem appropriate.

\footnotetext{
${ }^{220}$ Ibid. p. 92.

${ }^{221}$ Ibid. p. 98.
} 


\section{Psychoanalysis and Christian Tradition}

Two significant studies appeared recently that argued that psychoanalysis constituted a restatement in modern secular terms of a psychology once formulated by Christian theology. In the first of these, Why Freud Was Wrong (1995), Richard Webster argued that Freud's basic concepts are 'not fresh theories of human nature but Judaeo-Christian orthodoxies which have been reconstructed in a secular form' ${ }^{222}$ There are several similarities between the theology of original sin and Freud's concept of the unconscious. Webster notes that both doctrines 'universalised the concept of illness', that is, they attributed a body of negative impulses beyond conscious control to all human beings. ${ }^{223}$ Whilst individuals might achieve a certain degree of control over these impulses, they remain endemic. Psychoanalysis recasts the concept of an innate tendency to evil, against which one must struggle in order to live a fully human life, which had been established by the theology of original sin. Just as in Christianity everyone stands in need of grace as a result, so in psychoanalysis everyone needs to overcome the Oedipus complex. Webster also points out that in attributing incestuous and aggressive tendencies to children, Freud did not innovate as radically as is sometimes suggested. He writes that according to the doctrine of original sin, "children do not come into the world and then learn how to sin, but come into the world bringing their sinful sensuality with them ${ }^{224}$ In Webster's view, Freud's theory of infantile sexuality represents a restatement of this position.

\footnotetext{
${ }_{222}$ Richard Webster, Why Freud was Wrong: Sin, Science and Psychoanalysis (London: Harper Collins, 1995) p. 7.

223 Ibid. p. 314.

${ }^{224}$ Ibid. p. 330.
} 
In The Religious and Romantic Origins of Psychoanalysis (1996), Suzanne R. Kirschner situates modern American forms of psychoanalysis in an argument familiar to readers of M.H. Abrams' Natural Supernaturalism (1971). Kirschner maps out the 'psychoanalytic developmental narrative', which she finds most clearly and representatively expressed in the work of Margaret S. Mahler (18971985). She describes this process as a "developmental spiral". ${ }^{225}$ The infant is initially aware of a blissful symbiotic 'dual-unity' with the mother, from which he 'individuates' or assumes his own individual characteristics. This leads to a sense of helplessness and vulnerability, which is overcome by forming a sense of relatedness to objects whilst preserving a sense of individual integrity. The initially disappointing existence of self and other must be accepted and integrated, in order that meaningful and satisfying relationships with others can be formed. This trajectory can also be plotted in Freud's theories. As Richard Webster writes, 'Freud saw human history as a difficult upward progress from the realm of the flesh to the realm of the spirit'. ${ }^{226}$ The pre-Oedipal infant experiences a series of initially uninhibited gratifications, which his increasing awareness of threats of punishment obliges him to renounce. These renunciations culminate in the repression of the Oedipus complex, and the resulting internal conflict. Nevertheless, this conflict is the precondition for the more valuable attainment of moral maturity and contribution to the process of civilisation.

Kirschner compares Mahler's narrative with the patristic tradition of Neoplatonic Biblical exegesis. In Neoplatonic thought, the highest and most fundamental reality is the One, which is also the Good, from which all entities

\footnotetext{
${ }_{25}$ Suzanne R. Kirschner, The Religious and Romantic Origins of Psychoanalysis: Individuation and Integration in Post-Freudian Theory (Canbridge: Cambridge University Press, 1996) p. 77 passim.

${ }^{26}$ Webster, Why Freted was Wrong p. 311.
} 
emanate in varying degrees, and to which they strive to return. The soul can achieve this return by turning inwards from the sensible world to contemplate in itself the One that is its source. ${ }^{227}$ M.H. Abrams describes the Biblical exegesis influenced by this kind of thought, initiated by Origen (c. 185-254), in which God is conceived primarily as a principle of unity rather than as a father, the Fall is conceived primarily as 'alienation from the source', the original sin as selfcentredness, and redemption as a return to lost unity with God propelled by the sustaining energy of His love. ${ }^{228}$ Kirschner compares this historical narrative, recast at the individual level by mystics like Jakob Boehme (1575-1624) and the Romantics, to the psychoanalytic developmental narrative. Both describe the same trajectory of 'unity, rupture and division into contraries, higher unity'. ${ }^{229}$ She argues that psychoanalysis follows Neoplatonic Christian theology in asserting that 'human selfhood...originates in and emanates out of an undifferentiated unity', in the former with the mother and in the latter with God. ${ }^{230}$ In both systems, 'the recognition of one's estrangement from [this] 'source' is associated with self-consciousness... and suffering' ${ }^{231}$ Freud describes it as being 'cast out of...paradise'. ${ }^{232}$ In both systems, the individual retains a deep yearning to return to the undivided state. Nevertheless, this estrangement constitutes a fortunate fall in both cases, leading to 'higher and more constructive forms of consciousness and relationship'. ${ }^{233}$ In Mahler's version of the psychoanalytic narrative, healthy development results in the capacity to form fulfilling relationships, whose prototype is marriage. For Freud,

\footnotetext{
${ }^{227}$ See R.T. Walsh, Neoplatonism (London: Duckworth. 1972) pp. 37-93.

${ }^{228}$ M.H. Abrams, Natural Supernaturalism: Tradition and Revolution in Romantic Literature (New York and London: Norton, 1971) pp. 146-154.

${ }_{229}$ Kirschner, The Religious and Romantic Origins of Psychoanalysis p. 180.

${ }^{230}$ Ibid. p. 183 .

${ }^{231}$ Ibid.
} 
successful negotiation of the Oedipus and castration complexes results in an adequate and lasting choice of love-object. ${ }^{234}$ Kirschner compares this 'higher union' (than with the mother) to the higher union (than the prelapsarian) with God, described by the mystics as the 'divine marriage' of God and the soul. ${ }^{235}$

Webster bases his argument that Freud re-writes certain Christian doctrines on the position that these doctrines had become so unfamiliar in Freud's rationalist milieu that he was unaware of his debt to them. Freud's treatment of Christian theology is not detailed, but it is too contrary to his cultural knowledge to suggest that he was simply unaware of the historical significance of the doctrine of original sin, for example. ${ }^{236}$ Nevertheless, the similarities between Freud's concept of the unconscious and the doctrine of original sin are as pronounced as Webster argues. Kirschner's thesis that psychoanalysis owes the structure of its developmental narrative to Neoplatonic Christianity by 'cultural genealogy' or 'the redeployment of a pre-existing cultural template to a new context' is more plausible. ${ }^{237}$ Put simply, it means that Freud built his theory out of the materials around him. This means that psychoanalysis has less claim to explain or interpret Christian doctrines in its own terms than one might expect, given the prevalence of this kind of interpretation. All of Kristeva's studies on religion, for example, read Christian texts in psychoanalytical terms. In In the Beginning Was Love (1985), she writes that 'the Credo embodies basic fantasies'. ${ }^{238}$ Webster's and Kirschner's studies, on the other hand, show that the basic fantasies described by

\footnotetext{
${ }^{232}$ SE XIX p. 173.

${ }^{233}$ Kirschner, The Religious and Romantic Origins of Psychoanalysis p. 185.

${ }^{234}$ PFL 1 p. 380.

${ }^{235}$ Kirschner. The Religious and Romantic Origins of Psychoanalysis pp. 190-191.

${ }^{236}$ It could be pointed out that Webster's own understanding of the doctrine does not appear profound. He speaks for example of its 'exponents...deliberately setting out to create anxiety and exacerbate feelingsof guilt' (Why Frend Was Wrong. p. 321).

${ }^{237}$ Kirschner, The Religious and Romantic Origins of Psychoanalysis p. 7.
} 
psychoanalysis can also be said to embody the Creed. The structural debt of psychoanalysis to Christianity calls into question the privilege of the former as a hermeneutic code. If psychoanalysis owes some of its own formulations to Christian theology, it is difficult to see it as an exhaustive explanation of such theology.

Webster and Kirschner are in their different ways concerned to show that psychoanalysis is not as based on empirical observation as it claims. In their article 'Christianity and Psychoanalysis' (1984), Paul C. Vitz and John Gartner consider psychoanalysis from an orthodox Christian point of view. They see it as 'a useful theoretical representation of the psychology of sinful humans'. 239 Whilst they do not follow Freud in seeing the Oedipus complex as universal, they write:

There is no barrier to Christian acceptance of the basic psychology of the Oedipus complex as a...description of the psychological nature of original sin in the lives of many. ${ }^{240}$

They see the essence of original sin as a tendency towards a fictitious autonomy, and they see the concept of the Oedipus complex as a description of this tendency. 'It is a specific representation of the struggle to become an autonomous ruler of our own and others' lives ${ }^{241}$ Discussing Freud's argument that religion is a wish-fulfilment, Vitz and Gartner point out that it follows from the logic of the Oedipus complex to think rather of atheism as a wish-fulfilment. The Oedipal child wishes to kill the father and replace him. Freud thinks of God as a substitute for the father, and so the position that He does not exist can be seen as a fulfilment of this wish. If, as in Freud's case, religion is replaced with a

\footnotetext{
${ }^{238}$ Julia Kristeva, In the Beginning Was Love: Psychoanalysis and Faith, tr. Arthur Goldhammer (New York: Columbia University Press, 1987) pp. 39-40.

${ }^{239}$ Paul C. Vitz and John Gartner, 'Christianity and Psychoanalysis, Part I: Jesus as the AntiOedipus', Journal of Psychology and Theology 12 (1984) p. 5.

${ }^{240}$ Ibid. p. 8.
} 
system confined to the human sphere, the infantile wish to replace the father with oneself has also been fulfilled. As Vitz and Gartner write, "God is dead" is... an undisguised Oedipal wish-fulfilment'. ${ }^{242}$ They see this as further reason to think of the Oedipus complex as a description of original sin, which involves rebellion against God. They write, 'Oedipal motivation is the satanic resistance to God deeply stained into human nature' ${ }^{243}$

This identification of the Oedipus complex and original sin is possible only in the most general sense, however, as we can see from St. Thomas Aquinas' formulation of the doctrine in the Summa Theologiae. St. Thomas defines original $\sin$ as a habitus, by which he means 'a modification of a nature composed of many elements, according as it bears itself well or ill towards something' ${ }^{244}$ Original $\sin$, he writes, is a 'disordered disposition [habitudo inordinata]' of the powers of the soul, which predisposes each person to acts his or her adult conscience would reject. ${ }^{245}$ This disorder derives from the primordial turning of the human will from its subjection to the will of God, which constituted original justice, and it can be observed in an 'unruled [inordinate] turning to goods that pass away', which Aquinas calls by the Augustinian name 'concupiscence'. ${ }^{246}$ In its decree on original sin (1546), the Council of Trent states:

In the baptised [whose original sin is remitted], there remains concupiscence or an incentive to $\sin$ [fomes peccati]...[It] is of $\sin$ and inclines to $\sin ^{247}$

\footnotetext{
241 Ibid.

${ }^{242}$ Ibid. p. 13. As we have seen, Freud also attributes love for the father to the infant. Vitz and Gartner acknowledge this but argue that in praclice Freud is more concerned with the infant's aggression towards him.

243 Ibid.

${ }_{244}$ Thomas Aquinas, Summa Theologiae Ia-IIae 82, 1.

245 Ibid.

${ }^{246}$ Ibid. Ia-Iiae $82,3$.

${ }^{247} \mathrm{See}<\mathrm{http} / / /$ history.hanover.edu/early/trent/ct05os.htm> no. 5.
} 
It is impossible to equate the Freudian theory of the instincts with original sin or with concupiscence so conceived. The disorder of the powers of the soul for Aquinas is understood with respect to their proper order, and original sin is understood as a privation of original justice. The Freudian instincts have no such point of reference. There is no value of which they represent the lack. They are not considered as evil or as tendencies to evil but as facts of experience. Whereas original sin and concupiscence are contingent upon something more fundamental, the Freudian instincts are conceived as themselves fundamental.

Nevertheless, there are certain similarities between the two theories. Both describe a drive towards self-gratification that must be overcome in an authentically human life. This is particularly clear in St. Augustine's formulation of the doctrine of original sin. In De Civitate Dei (413-426), he asserts that the essence of $\sin$ is 'to abandon God and to exist in oneself, that is, to please oneself ${ }^{248}$ The concept of pleasing oneself as opposed to God is similar to Freud's concept of pleasing oneself as opposed to society. Like Freud, Augustine writes that this drive towards self-gratification results in psychological conflict with the adult will. He writes:

Man's wretchedness is nothing but his own disobedience to himself, so that... he now wills to do what he cannot... [He] is disobedient to himself, while his very mind and even his lower element, his flesh, do not submit to his will. ${ }^{249}$

This conflict of drives, which St. Paul describes as that between 'the law of $\sin ^{\prime}$ and 'the law of God' (Rom. 7:25), is similar to the conflict Freud describes between the pleasure principle and the reality principle.

We cannot identify Freud's concept of the unconscious with the doctrine of original sin, although there are structural similarities in the two theories. The 
Freudian instincts are not a description of concupiscence nor vice versa. We can say, however, that psychoanalysis is not incompatible with the theology of original sin. There could in principle be both a Freudian unconscious and concupiscence, since Freud describes a psychological conflict of which Christian theology has been aware since St. Paul's expression of it at Romans 7:14-25. This means that, as I argued with respect to psychoanalytic accounts of religion, there is no inconsistency implied in the use of psychoanalytic methods in Christian criticism. Indeed, these methods may illustrate psychological conflicts in literary texts which we can then interpret in terms of Christian anthropology.

(iii) A Critique of Psychoanalytic Literary Theories

Having established that it is in principle possible to use psychoanalytic methods in Christian criticism, I will now assess to what degree we should in fact do so. There are several significant critiques of psychoanalysis that we must take into account in order to make this judgement.

\section{The Empirical Critique}

In Conjectures and Refutations (1963), Karl R. Popper writes that the criterion of demarcation between a scientific theory and a pseudo-scientific theory is that the former alone possesses 'falsifiability, or refutability, or testability'. ${ }^{250}$ For Popper, science does not proceed by induction, as is commonly thought, but by a 
process of trial and error. A hypothesis is formed, and then tested by repeated observations and experiments which attempt to refute the hypothesis. Psychoanalysis begins with conjectures but does not attempt to refute them in the manner of a science, for Popper. He writes that its theories 'contain most interesting psychological suggestions, but not in a testable form? ${ }^{251}$ Any human act can be explained in terms of psychoanalysis: it finds verification everywhere. But this apparent hermeneutic strength is precisely its scientific weakness. If psychoanalytic theories are not falsifiable, according to Popper, they cannot be accounted scientific.

In 'Freud and the Idea of a Pseudo-Science' (1970), Frank Cioffi extends this critique. He assesses the 'empirical character' claimed for psychoanalytic theories, and concludes that in fact they constitute a 'pseudo-science'. ${ }^{252}$ His use of this word is stronger than Popper's: he means not only a system whose procedures in fact prevent the discovery of disconfirmations but one whose procedures' function is to prevent such discovery. He writes, 'To claim that an enterprise is pseudo-scientific is to claim that it involves the habitual and wilful employment of methodologically defective procedures'. ${ }^{253}$ Such procedures characterise psychoanalysis, in Cioffi's view. He rightly points out that Freud often seems to suggest that he has inferred conclusions about the determination of symptoms by an independent investigation of sexual life, and that on a closer reading, this turns out not to be the case. Freud's accounts of the Oedipus and castration complexes are examples of this. On one hand Freud suggests that

\footnotetext{
${ }^{250}$ Karl R. Popper, Conjectures and Refutations: The Growth of Scientific Knowledge (London: Routledge and Kegan Paul, 1963) p. 37.

${ }_{251}$ Ibid. p. 38.

${ }^{252}$ Robert Borger and Frank Cioffi, eds., Explanation in the Behavioural Sciences (Cambridge: Cambridge University Press. 1970) p. 471.

${ }^{253}$ Ibid. p. 472.
} 
these hypotheses could be tested by observing the behaviour of children. $\mathrm{He}$ even asserts that this behaviour confirms his hypotheses so clearly that one would have go to some lengths to avoid noticing it. ${ }^{254}$ On the other hand Freud writes in the prefaces to the Three Essays on the Theory of Sexuality that only the psychoanalytically trained can make the proper inferences from the observation of children to the Freudian hypotheses. Freud writes, 'If mankind had been able to learn from direct observation of children, these... essays could have remained unwritten' ${ }^{255}$ Clearly, empirical confirmation of Freud's theories of sexuality is not as obviously available as he often implies. Cioffi points out that the extent to which psychoanalysis accords with the empirical observation of children is the only way of establishing the validity of its clinically derived hypotheses concerning them. What he calls the 'retreat to the esoterically observable' in the face of disconfirmatory evidence simply begs the question of the validity of the analytic hypotheses. ${ }^{256}$ Freud's oft-expressed preference for analytic reconstructions (from free-association, dream-interpretation and so on) over empirical investigation of an individual's past similarly begs the question of the validity of these reconstructions. Furthermore, Freud posits a phylogenetic heritage of fantasies corresponding to memories of Oedipal wishes and castration threats in individuals who have not directly experienced these wishes or threats themselves. As Cioffi writes, if Freud could attribute a discrepancy between his reconstruction of a patient's infancy and the empirically constructable events of that infancy to a phylogenetic heritage, he could never discover invalidity in his reconstructions. As a result Cioffi describes these reconstructions as 'pseudo-

\footnotetext{
${ }^{254}$ See 'The Resistances to Psychoanalysis', SE XIX p. 220.

${ }^{255}$ Freud, 'Three Essays on the theory of Sexuality', SE VII p. 133.

${ }^{256}$ Borger and Cioffi, Explanation in the Behavioural Sciences p. 479.
} 
narratives', which impose 'spurious allusions' between events whose real relation is unconfirmed and unlikely. ${ }^{257}$

Cioffi's critique is more pertinent than Popper's. There is no reason why psychoanalysis is not in principle falsifiable, as the latter asserts. The long tradition of experiments designed to test psychoanalytic hypotheses suggests that they are in principle testable. Cioffi's argument, that psychoanalysts rarely attempt to test their hypotheses in practice, however, is fair. There is no doubt that this is almost always true of Freud. Lacan and Kristeva make occasional references to experiments or independent confirmations of their own distinctive additions to psychoanalysis, but insofar as they accept Freud's ideas they use empirically unconfirmed concepts. ${ }^{258}$ Furthermore, Cioffi is right to assert that the sources of Freud's hypotheses are on the whole inaccessible in principle to an independent observer. The knowledge of the unconscious derived from dream-interpretation is an example. The only conceivable way to test the veracity of a dream-interpretation is to check it against the opinion of the dreamer. According to Freud this is not possible, since the dreamer continues to repress his dream-wishes in waking life. His interpretations of his patient's dreams then become a matter merely of assertion. It is impossible to gainsay them, since even their subject, the dreamer, is denied awareness of the correct interpretation. They are acts of absolute authority on Freud's part. Perhaps this would be of little significance if it were not that dream-interpretation provided Freud with most of his knowledge of the unconscious. He described it as 'the royal road to a knowledge of the unconscious' ${ }^{259}$ This means that the qualities Freud predicated of the unconscious are largely derived from statements that

\footnotetext{
257 Ibid pp. 483, 489.

${ }^{258}$ See Lacan, Ecrits p. 1; Kristeva, Desire in Language pp. 133-134.
} 
cannot be checked, either in practice or in principle. As Richard Webster writes, 'If the psychoanalyst himself made up the rules for decoding dreams, these could be formulated in such a way that dreams would always yield the desired conclusion', ${ }^{260}$ Freud is the sole and final authority for the nature he attributes to the unconscious. Although it is not impossible that he always or often interpreted dreams or described the unconscious rightly, there is simply no way of knowing. ${ }^{261}$ In the absence of this knowledge there is no reason for assent. A second example of inaccessible evidence is Freud's self-analysis, from which he derived the materials for the theory of the Oedipus complex. This self-analysis was conducted in 1897 and Freud described its results in a series of letters to his friend Wilhelm Fliess. Its results, as with those of any introspection, are entirely untestable by an independent observer. Freud writes, 'I have found in my own case...falling in love with the mother and jealousy of the father, and I now regard it as a universal event of early childhood'. ${ }^{262}$ In Skeptical Engagements (1986), Frederick Crews describes this as 'a set of intuitions that were revealed to the Master in an access of personal transcendence'. ${ }^{263}$ Whilst this is rather overstated - the analysis did not have the spontaneous character of an intuition it accurately describes the absolute authority with which Freud predicates qualities of the unconscious. As in the case of dream-interpretation, in the

\footnotetext{
${ }^{259}$ PFL 4 p. 769.

${ }^{260}$ Webster, op. cit. p. 264. Webster criticises a series of self-confirming hermeneutic strategies described by Freud in The Interpretation of Dreams such as the interpretation of dreams that do not seem to fulfil wishes as wishes that Freud's theory of dreams might be wrong (PFL 4 p. 254; Webster pp. 264-272). The existence of 'counter-wish' dreams, which Freud also tried to explain by a masochistic tendency in the dreamer, is the clearest disconfirmation of Freud's dreamtheory. See Edward Erwin, A Final Accounting: Philosophical and Empirical Issues in Freudian Psychology (Cambridge, MA and London: MTT Press, 1996) pp. 288-290.

${ }^{261}$ This is the closest point of similarity of psychoanalysis to religion. In the absence of testable evidence, its statements have to be taken on faith.

262 SE I p. 265.

${ }^{263}$ Frederick Crews, Skeptical Engagements (New York and Oxford: Oxford University Press, 1986) p. 61 .
} 
absence of any means of checking these predications, we have no reason to assent to them.

As I pointed out above, however, there have been extensive attempts to test the validity of psychoanalytic hypotheses experimentally. There have been over 1500 such experiments. ${ }^{264}$ In their anthology The Experimental Study of Freudian Theories (1973), Hans J. Eysenck and Glenn D. Wilson collect and analyse twenty-one experiments, most of which are 'considered by experts to reflect favourably on psychoanalytic hypotheses,.265 In the conclusion to their analyses, Eysenck and Wilson list a series of faults they find with the experiments in general. The most pervasive of these is a "failure to discuss alternative hypotheses'. ${ }^{266}$ Many of the experiments, they write, make a deduction from Freudian theory, provide results in partial agreement it, but then 'fail to consider the duty incumbent upon any scientist to consider alternative hypotheses which might equally well, or even better, explain the results found'. ${ }^{267}$ Even in the experiment Eysenck and Wilson find most properly executed, that of Irving Sarnoff and Seth M. Corwin on the relation of castration anxiety and the fear of death (1959), alternative hypotheses are not adequately considered. ${ }^{268}$ For example, castration anxiety was determined by the degree of distress registered at a picture of a dog observing another with a knife over its tail. Eysenck and Wilson point out that 'a personality dimension such as anxiety or emotionality' is just as likely, if not more so, to be registered by the response

\footnotetext{
${ }^{264}$ See Erwin, A Final Accounting p. 146.

${ }^{265}$ Hans J. Eysenck and Glenn D. Wilson, The Experimental Study of Freudian Theories (London: Methuen, 1973) p. 385.

${ }^{266}$ Ibid. p. 386.

267 Ibid. pp. 386-387.

${ }^{268}$ Ibid. pp. 140-155.
} 
to this picture. ${ }^{269}$ What is certain is that the experiment made no provision to establish whether or not this was the case. Eysenck and Wilson also criticise the indefinite nature of the Freudian theories tested, particularly with respect to the role of reaction-formation, which is employed to account for contradictory results without the establishment of proper criteria as to when it could be expected to occur. ${ }^{270}$ They also criticise the predominant lack of repetition of the experiments. They conclude that the experiments they have collected 'give little if any support to Freudian concepts and theories'. 271 They write, "There is not one study to which one could point with confidence and say "Here is definitive support of this or that Freudian notion"', 272

In A Final Accounting: Philosophical and Empirical Issues in Freudian Psychology (1996), Edward Erwin takes account of post-1980 experiments unavailable to Eysenck and Wilson. He concludes that like the previous body of research, it '[yields] very little support, if any, for Freudian theory'. ${ }^{273}$ Erwin notes that most psychologists accept that unconscious mental events occur, and he allows that experimental evidence suggests that there may be unconscious mental events which have an effect on behaviour, as M.H. Erdelyi posited in Psychoanalysis (1985). He also accepts Erdelyi's account of repression as what occurs when we 'intentionally keep something out of consciousness in order to avoid psychological pain', such as denial of a terminal illness. ${ }^{274}$ But the Freudian concepts of the unconscious and repression remain unconfirmed. Erwin writes, 'The amount of confirmation of distinctively Freudian hypotheses is

\footnotetext{
${ }^{269}$ Ibid. p. 153.

270 Ibid. pp. 387-388.

271 Tbid. p. 392.

${ }^{272}$ Ibid.

${ }^{273}$ Erwin, A Final Accounting p. 236.

${ }^{274}$ Ibid. p. 284.
} 
close to zero'. ${ }^{275}$ Indeed, some of them have been disconfirmed, such as Freud's theories of the aetiology of the neuroses. If these theories were true, we should expect that relapse or resumed symptoms would generally follow treatments that were not aimed at bringing repressed wishes into consciousness. But, as Erwin writes, 'that prediction has been disconfirmed by numerous studies of behavioural and cognitive-behavioural therapies'. ${ }^{276} \mathrm{He}$ adds that the same applies to the existence of counter-wish dreams with respect to Freud's theory of dreams. He concludes, like Eysenck and Wilson, that virtually none of Freud's theories have been confirmed by the evidence of empirical observation. He adds that there are disconfirmations which provide some reason to think some of the theories false, although they do not prove this. Given that this is the conclusion to be drawn after a sixty-year experimental tradition comprising over 1500 experiments, Erwin adds that the theories are unlikely to be confirmed in the future.

It is clear that the truth of Freud's theories remains empirically unconfirmed. Whilst there may be some patients who derive some benefit from psychoanalysis, there is no reason to assume that they have derived this benefit as a result of the truth of the theories upon which the analysis is based. The result of this conclusion for psychoanalytic criticism is that there is no reason to believe that it contributes to increased knowledge of the text towards which it is directed. There is no doubt that much psychoanalytic criticism is valuable for its imaginative and creative qualities. But there is equally no doubt that it is not valuable for the truth of its assertions. For example, Kristeva's tracing of an alternative physical register underneath the logic and syntax of Mallarmé's

\footnotetext{
275 Ibid. p. 294

${ }^{276}$ Ibid. p. 288.
} 
poetry, whilst compelling, cannot be taken as the referential description it is presented to be. There is simply no reason to assume that it really describes an infantile articulation of the drives. As we said with respect to Freud's basic theories, it might be true, but there is no way of knowing whether it is. This must be our verdict on all the psychoanalytic criticism we have discussed. It means that Christian literary theory has no reason to assimilate the conclusions or to endorse the methods of psychoanalytic criticism. Whilst it implies no contradiction of Christian theology, psychoanalytic theory cannot be taken to describe any reality concerning literary texts, and as such we have no reason to use its methods.

\section{The Feminist Critique}

In 1927, Freud's otherwise orthodox disciple Ernest Jones described the 'unduly phallo-centric view' of development established by male psychoanalysts. ${ }^{277}$ In New Ways in Psychoanalysis (1939), the psychoanalyst Karen Horney attempted to eliminate the 'debatable premises' on which she saw Freud's system to be constructed in order to enable psychoanalysis fully to realise its therapeutic potential. ${ }^{278}$ One such premise, in her view, was the concept of penis-envy, in terms of which Freud described almost every female characteristic. Horney writes that it is 'contradictory to biological thinking' to assert that women, "physically built for specifically female functions, should be psychically determined by a wish for attributes of the other $\operatorname{sex}^{2}{ }^{279}$ The data

\footnotetext{
277 Ernest Jones, Papers on Psychoanalysis, $4^{\text {th }}$ ed., (London: Ballière, Tindall and Cox, 1938) p. 556.

${ }^{278}$ Karen Horney, New Ways in Psychoanalysis (London: Kegan Paul, 1939) p. 8.

${ }^{279}$ Ibid. p. 104.
} 
from which the concept is induced are scant, she points out, all of them readily permitting a different interpretation. Whilst Freudians may take female tendencies like nagging, envy or ambition as indications of penis-envy, Horney writes, 'these trends are sometimes imputed to underlying penis-envy without further evidence ${ }^{280}$ What Freud also fails to take into account, according to Horney, are the cultural factors that contribute to the female characteristics he describes. For Freud, 'anatomy is destiny'. ${ }^{281}$ Horney accepts that differences in sexual constitution and function influence mental life, but denies that they determine it as entirely as Freud in practice asserts. If psychoanalysis is genuinely to determine the sources of its patients' motivations, in Horney's view, it must also account for 'the way specific cultural constitutions engender specific qualities and faculties' in both men and women.

In Sexual Politics (1970), Kate Millett offers a sustained critique of Freud's account of feminine sexuality. In order to account for the transfer of a girl's object-cathexis from her mother to her father, Freud hypothesised that 'girls hold their mother responsible for their lack of a penis and do not forgive her for their being thus put at a disadvantage' ${ }^{282}$ Their consequent 'envy for the penis' leaves 'ineradicable traces on their development and the formation of their character, ${ }^{283}$ Millett follows Horney in suggesting that if girls have perceived themselves to be inferior to boys, this is more a result of 'the conditions of patriarchal society and the inferior position of women within this society' than of their lack of a penis. ${ }^{284}$ Why should the little girl perceive her brother's or playmate's penis as something enviable, after all? 'Might she just as easily

\footnotetext{
${ }^{280}$ Tbid. p. 106.

281 SE XIX p. 178.

282 'Femininity', PFL 2 p. 158.

${ }^{283}$ Tbid. p. 159.
} 
imagine...the penis is an excrescence and take her own body as the norm?' Millett asks. ${ }^{285}$ This is what boys do, in the Freudian account, and he gives no good reason why girls should not. As Horney had suggested, it seems unlikely that one half of humanity should have a biological reason to prefer what the other half possesses but not vice versa. 'It is especially curious...that half the race should attribute their clear and obvious social-status inferiority to the crudest biological reasons', Millett adds. ${ }^{286}$ Even if one were to hypothesise exclusively at the physical level, she writes, 'surely the first thing all children must notice is that the mother has breasts while the father has none'. ${ }^{287}$ She concludes that the subjectivity attributed to infants in Freud's developmental theories is marked by 'a strong masculine bias', which she identifies with Freud's own. This masculine bias extends to the social function of Freud's theories, Millett continues. Often, 'Freud's language makes no distinction...between fact and feminine fantasy', that is, it slips from a description of the girl's perception of inferiority to an assumption that this inferiority really exists. ${ }^{288}$ The theory of penis-envy perpetuates the social inferiority of women, Millett writes. It converts childbirth, 'an impressive female accomplishment' and the only one recommended by Freud, into 'nothing more than a hunt for a male organ' ${ }^{289}$ She points out that by attributing 'little sense of justice' to women, Freud deprives them of the 'moral position which is their...claim for just treatment ${ }^{290}$ Millett concludes that Freud's female psychology is based on an inadequate distinction between women's physical

\footnotetext{
${ }^{284}$ Kate Millett. Sexual Politics (London: Virago, 1970) p. 180.

${ }^{285}$ Toid. p. 181.

${ }^{286}$ Ibid. p. 183.

${ }^{287}$ Ibid.

${ }^{288}$ Ibid.
} 
constitution and their social position, the result of which is the assertion that 'a man's world has made of woman... what nature had made of her first' ${ }^{291}$

The most sustained feminist critique of Freud is Luce Irigaray's essay, 'The Blind Spot of an Old Dream of Symmetry' (1974), in which she closely reads Freud's essay 'Femininity' (1933). The essence of Irigaray's critique is that 'the "differentiation" into two sexes derives from the a priori assumption of the same' ${ }^{292}$ This means that Freud's account of female psychology is constructed in terms in which male psychology is unjustifiably taken as a norm. In his account of the girl's phallic stage of libidinal organisation, Freud writes that 'the little girl is a little man'. ${ }^{293}$ Irigaray questions why a girl should enter a 'phallic' stage at all, in which her libido is as centred upon the male organ as the boy's. She writes that if, as Freud asserts, a girl is to pass through phases of libidinal organisation, there should surely be vulvar, vaginal and uterine stages to account for. ${ }^{294}$ In the phallic phase, according to Freud, the clitoris, the girl's 'smaller penis-equivalent' is her primary erotogenic zone. This is 'against all rhyme and reason' of female physiology, Irigaray writes. ${ }^{295}$ In order to account for the girl's development in the same (phallic) terms as the boy's, Freud has to give an oddly censored and restricted account of women's ordinary experience of sexuality. There is no good reason other than the desire to make female development conform to the male pattern why the girl should begin to hate her mother in a way that the boy does not, Irigaray continues. The discovery of castration and

\footnotetext{
${ }^{289}$ Ibid. p. 185. See PFL 2 p. 162: 'The feminine situation is only established... if the wish for the penis is replaced by one for a baby...in accordance with an ancient symbolic equivalence .

${ }_{90}$ Millett. op. cit. p. 189 . See PFL 2 P. 168.

291 Ibid. p. 190.

${ }^{292}$ Luce Irigaray, Speculum of the Other Woman, tr. Gillian C. Gill (New York: Columbia University Press, 1985) p. 27.

${ }^{293}$ PFL 2 p. 151.

${ }^{294}$ Irigaray, op. cit. p. 29.

295 Ibid.
} 
resulting penis-envy is an answer as suspect as the question. For Irigaray, Freud uses the concept of penis-envy in order to establish that the man is the norm in human development. She finds it suspicious that the desire for the penis Freud attributes to women confirms the value of being a man and the inferior value of being a woman. It confirms that a woman is a man who lacks certain things. As Irigaray puts it, 'Envy, jealousy, greed are all correlated to lack... All these terms describe female sexuality as merely the other side... of a male sexualism? ${ }^{296}$ Freud does not allow for the possibility that women have 'other desires, of a different nature from his representation of the sexual'. ${ }^{297}$ This is presumably the reason Freud posits no envy for the vagina or for the uterus, Irigaray asserts. It is quite possible to conceive of two separate sexual economies, she writes, in which each pole would desire the attributes of the other, but for Freud sexuality is in the end a matter of being plus or minus the one phallus. ${ }^{298}$ As she puts it in her interview 'The Power of Discourse and the Subordination of the Feminine' (1975), 'All Freud's statements describing female sexuality overlook the fact that the female sex might... have its own "specificity", 299

There are two fundamental criticisms made of psychoanalysis in these critiques, which we could call ethical and hermeneutic. The ethical criticism, made most strongly by Kate Millett, is that the social function of psychoanalysis is to keep women in the subordinate positions they have traditionally occupied in Western societies. Feminist writers are not agreed on this point, however. In Psychoanalysis and Feminism (1974), Juliet Mitchell argues that

\footnotetext{
296 Ibid. p. 51.

${ }^{297}$ Tbid.

${ }^{298}$ Ibid. p. 52.

${ }^{299}$ Margaret Whitford, ed., The Irigaray Reader (Oxford: Blackwell, 1991) p. 119. In 'The Poverty of Psychoanalysis' (1977), in ibid. pp. 79-104, Irigaray argues a similar case with respect to Lacan's concepts of the imaginary, symbolic and real registers.
} 
'psychoanalysis is not a recommendation for a patriarchal society, but an analysis of one ${ }^{300}$ For Mitchell, the theory of the Oedipus complex accurately describes the process of assuming a social role within such society. She writes, 'The psychoanalytic concept of the unconscious is a concept of mankind's transmission and inheritance of his social (cultural) laws', ${ }^{301}$ In Mitchell's Marxist perspective, the concept corresponds to an analysis of the psychological effect of patriarchal ideology. ${ }^{302}$ As a contribution to ideological analysis, psychoanalysis is a potentially useful tool for revolutionary feminism. ${ }^{303}$ In Jacques Lacan: A Feminist Introduction (1986), Elizabeth Grosz points out that Lacan's theories can be seen to have a similar value. She writes:

His decentring of the rational conscious subject... [has] helped to free feminist theory of the constraints of a largely metaphysical and implicitly masculine notion of subjectivity. ${ }^{304}$

Given that such feminist defences of psychoanalysis exist, we cannot immediately disregard its critical methods on grounds of social ethics.

The hermeneutic criticism is more serious, however. It means that Freud's theories do not adequately explain female psychology. Female development and sexuality represent data to which the theories of the Oedipus and castration complexes are insufficient explanatory hypotheses. There are two reasons for which we might accept the theory of penis-envy. The first would be that the theory is confirmed by observation. Freud himself tells us that this is not possible, however. He writes, 'One has opportunities of seeing little girls and

\footnotetext{
${ }^{300}$ Juliet Mitchell, Psychoanalysis and Feminism (London: Allen Lane, 1974) p. xv.

${ }^{301}$ Ibid. pp. $402-403$.

${ }^{302}$ Ibid. pp. 412-416.

${ }^{303}$ Mitchell makes a similar point with respect to Lacan in her introduction to Feminine Sexuality: Jacques Lacan and the École Freudienne (London: Macmillan, 1982) pp. 1-26. ${ }^{304}$ Elizabeth Grosz, Jacques Lacan: A Feminist Introduction (London and New York: Routledge, 1986) pp. 148-149.
} 
notices nothing of the sort'. ${ }^{305} \mathrm{He}$ adds that this is because a child can communicate only very little of its sexual wishes. We have already established the reasons why we cannot assent to the characteristics Freud attributes retrospectively to the unconscious. The second reason for which we might accept the theory of penis-envy despite this would be that it explains observable phenomena in women. This is not the case, however. Freud asserts that the theory explains why women are more prone to jealousy than to men, why they are 'weaker in their social interests' and why they '[have] little sense of justice ${ }^{306}$ None of these attributes, however, can be regarded as commonly observable feminine characteristics, and in the absence of confirmatory evidence from Freud we cannot take them as such. We might add that the attribution of a diminished sense of justice to women is also inadmissible theologically. In the absence of these reasons to accept the theory of penis-envy, we must conclude that Freud has not adequately described female psychology, despite having claimed to have done so. ${ }^{307}$

This constitutes a second reason for Christian literary theory not to endorse or use the principles of psychoanalytic criticism. Since it cannot be accounted an empirical science, psychoanalysis can only be considered valuable as a human science, or as a system of interpretation. The feminist critique, however, makes it clear that it does not adequately account for half of humanity. In Freud and Philosophy (1970) Paul Ricoeur writes, 'Psychoanalysis is a hermeneutics...[It]

\footnotetext{
${ }^{305}$ PFL 2 p. 154.

306 'Some Psychical Consequences of the Anatomical Distinctions Between the Sexes', SE XIX p. 254; PFL 2 pp. 168-169.

${ }^{307}$ Freud acknowledged as much in almost every one of his essays on feminine sexuality. 'Our insight into these developmental processes in girls is unsatisfactory, incomplete and vague (SE XIX p. 179). '[What I have to say about femininity] is... incomplete and fragmentary (PFL 2 p. 169). In 'Some Psychological Consequences of the Anatomical Distinction Between the Sexes', he describes his conclusions as 'based on a handful of cases' (SE XIX p. 258).
} 
aims at giving an interpretation of culture in its entirety'. ${ }^{308}$ It is clear from the feminist critiques, however, that it can succeed in this only with respect to men. Psychoanalytic criticism cannot be considered valuable even as a system of interpretation, since it is incompetent to explain the psychological nature and social role of women in and pertaining to the texts it is used to interpret. Since psychoanalysis cannot thus produce a consistent knowledge of such texts, there is no compelling reason why Christian literary theory should accept or use its methods of interpretation.

This concludes the first part of this thesis. I have examined the three fundamental discourses of modern literary theory, all of which constitute significant arguments against the existence of God as it has been traditionally understood in Christian theology. I have argued that deconstruction, whilst it necessitates a certain understanding of Christian theological discourse, does not imply that such discourse is meaningless or refers to nothing, as is sometimes assumed to be the case. I have argued that the atheism of Marx and Freud rests on fallacies that render their views on religion unproved hypotheses. This means that the concept of Christian literary theory, as I have defined it in the introduction to this work, is a legitimate one today. I have begun to expound some of the principles of which such a theory might consist, by suggesting which elements of the modern theories I have examined it ought to accept and which it ought to reject. In the second part of the thesis, I will continue this exposition

\footnotetext{
${ }^{308}$ Paul Ricoeur, Freud and Philosophy: An Essay on Interpretation (New Haven and London: Yale University Press, 1970) p. 66.
} 
with an examination of some of the most significant Christian texts that pertain to literary theory. 


\section{Christian Tradition and Literary Theory}

In this chapter, I will examine some of the major texts of Christian tradition, and assess what they contribute to the contemporary practice of literary theory. I aim to show two things by this examination. Firstly, that a Christian tradition of literary theory exists, although it is little known or used in modern criticism, and secondly, how this tradition can be used in Christian literary theory today. The limited space of this chapter restricts my discussion to the most fundamental texts of the Western tradition, those of the Bible, St. Augustine (354-430) and St. Thomas Aquinas (1225-1274). Many other Christian writers could have been consulted with profit for this study, such as the Greek fathers on aesthetics, Pseudo-Dionysius (c. 500) on theological language, or Dante Alighieri (12651321) and the Italian humanists on the truth contained in poetry. Nevertheless, in order to give a concise picture of the Christian tradition of thought that pertains to literary theory, I will examine the work of those two doctors of the church who have discussed these subjects at the greatest length and with the greatest influence. I will examine their theories of language and of aesthetics, and will suggest how these theories can be used by Christian critics today.

\section{(i) The Bible}

The Bible contains several texts that are concerned at a fundamental level with the nature of language. I will offer an exposition of these texts, with a particular view to their relevance to the study of literary language. 


\section{The Logos}

The text with the profoundest implications for Christian thought on language is the prologue to the fourth gospel (Jn. 1:1-18). It begins:

In the beginning was the Word [logos], and the Word was with God and the Word was God. He was in the beginning with God. All things came into being through him and without him not one thing came into being. What has come into being in him was life, and the life was the light of all people (Jn. 1:1-4). ${ }^{1}$

There are several traditions which influenced the author of the fourth gospel with respect to this description of Jesus as the Logos. As C.K. Barrett points out in his commentary on the gospel of John (1978), the author's introduction of the term without explanation indicates that it was already familiar to his readers. ${ }^{2}$ The term has two fundamental senses. Firstly, it denotes 'reason', and hence the related concepts of 'reflection', and the 'explanation' or 'formula' of a thing. Secondly, it denotes 'that which is said', and hence 'word', 'speech' or 'narrative'. ${ }^{3}$ As C.H. Dodd writes in The Interpretation of the Fourth Gospel (1953), 'For us, the concepts [of thought and word] are distinct as they were not for Greek-speaking persons'. ${ }^{4}$ The Stoics distinguished between 'immanent logos' (logos endiathetos), or man's reason present in him, and 'expressed logos' (logos prophorikos), or that reason made known by the faculty of speech. ${ }^{5}$ In Stoic physics, the logos is the rational structure of the universe, which the Stoics

\footnotetext{
'This and subsequent citations from Scripture, unless otherwise indicated, are taken from the New Revised Standard Version Bible, ed. Wayne A. Meeks et al. (London: Harper Collins. 1989).

${ }^{2}$ C.K. Barrett, The Gospel According to St. John: An Introduction with Commentary and Notes on the Greek Text, $2^{\text {nd }}$ ed. (London: SPCK, 1978) p. 152. Cp. Rudolf Bultmann The Gospel of John: A Commentary, tr. G.R. Beasley-Murray, R.W.N. Hoare and J.K. Riches (Philadelphia: Westminster, 1971) p. 19.

${ }^{3}$ See Henry George Liddell and Robert Scott, A Greek-English Lexicon, rev. Henry Stuart Jones (Oxford: Clarendon, 1968).

${ }^{4}$ C.H. Dodd. The Interpretation of the Fourth Gospel (Cambridge: Cambridge University Press, 1953) p. 263. Cp. Barrett, St. John p. 152.
} 
identified with God. Man's reason is a fragment of this divine logos, by which he should order his actions as the divine logos orders the universe. ${ }^{6}$ This concept bears little direct resemblance to that of the evangelist, who thinks of the world (kosmos) as opposed to the logos rather than ordered by it. ${ }^{7}$ The evangelist's thought is closer to that of Philo of Alexandria (c.20 BC-c.50 AD). Philo sought to interpret his native Judaism in the light of Greek philosophy, in a way typical of "the kind of religious philosophy which emerged... from the cross-fertilisation of Hebrew and Greek thought' in the Near East at the time. ${ }^{8}$ Philo interpreted the Old Testament figure of Wisdom as the logos of Greek philosophy. ${ }^{9}$ In the Wisdom literature, Wisdom is said to be God's first creature, through which he created the world. Dodd describes it as 'the hypostasised thought of God, immanent in the world ${ }^{10}$ Philo knew from Ps. 33:6 that the heavens were made tôi logôi tou kuriou, 'by the word of the Lord'. Wisdom and the word of the Lord are closely allied in Wisd. 9:1-2: 'O God... who have made all things by your word [en logôi sou], and by your wisdom [têi sophiai sou] have formed humankind'. Philo writes that just as there is a logos endiathetos and a logos prophorikos in man, so God's immanent logos is His eternal Wisdom, and His expressed logos is the projection of His Wisdom into formless matter by which

\footnotetext{
${ }^{5}$ See J.N.D. Kelly, Early Christian Doctrines, $5^{\text {th }}$ ed (London: A. \& C. Black, 1977) pp. 17-19.

${ }^{6}$ See Marcia L. Colish. The Stoic Tradition from Antiquity to the Middle Ages Vol. I (Leiden: E.J. Brill, 1985) pp. 21-60.

${ }^{7}$ See Ernst Haenchen, John 1: A Commentary on the Gospel of John Chapters 1-6, tr. Robert W. Funk (Philadelphia: Fortress, 1984) p. 137; Rudolf Schnackenburg, The Gospel according to St. John Vol. 1, tr. Kevin Smyth (London: Burns and Oates, 1980) p. 481-482; Bultmann, John p. 24.

${ }^{8}$ Dodd. Fourth Gospel p. 54. See also Thomas H. Tobin, "The Prologue of John and Hellenistic Jewish Speculation', Catholic Biblical Quarterly 52 (1990) pp. 252-269.

${ }^{9}$ Schnackenburg, St. John pp. 485-487; Dodd, Fourth Gospel p. 66

${ }^{10}$ Dodd, Fourth Gospel p. 274.
} 
the universe was created. ${ }^{11}$ He speaks of the divine logos both as the image (eikôn) and as the firstborn son (protogonos huios) of God. ${ }^{12}$

There are many parallels between the figure of Wisdom in the Bible's Wisdom literature and the Johannine Logos. In Prov. 8:30, Wisdom is said to be with God (par'autou), just as in John 1:1 the Logos is pros ton theon, 'with God'. In Prov. $8: 22$, Wisdom is said to have been created at the beginning of God's ways (archên hodôn autou), and John describes the Logos as en archêi, 'in the beginning'. As we have already mentioned, Wisdom is repeatedly described as the agent of creation (Prov. 8:30, 3:19; Wisd. 9:2, 7:22), just as in John 1:3 it is said that all things came into being through the Logos (panta di'autou egeneto). Wisdom is described in terms of life (Prov. 8:35) and of light (Wisd. 7:26), and John 1:4 says of the Logos, 'In him was life and that light was the light of men'. In Enoch 42:2, Wisdom seeks to dwell among men, and they reject her, just as in John 1:10-11, the Logos came to his own but his own did not receive him. Sir. 24:23 identifies Wisdom with the Torah, or Law. Ernst Haenchen and Rudolf Schnackenburg point out in their commentaries on the fourth gospel that Rabbinic Jewish exegesis tended to interpret Wisdom in terms of the Torah. ${ }^{13}$ Dodd adds that in these exegeses, the Torah is given many of the characteristics that John attributes to the Logos, such as pre-existence, being with God, agency in creation, life and light. ${ }^{14}$ Commentators disagree on the differing extent to which the evangelist used orthodox Jewish ideas of Wisdom and of the Torah and to which he used Hellenistic interpretations of them such as Philo's.

\footnotetext{
${ }^{11}$ De Vita Mosis II, 127. See Dodd, Fourth Gospel p. 66.

${ }^{12}$ See ibid. p. 67; Sclmackenburg, St. John p. 486.

${ }^{13}$ Haenchen, John p. 138; Schnackenburg, St. John p. 485-46.

${ }^{14}$ Dodd, Fourth Gospel pp. 85-86.
} 
Haenchen argues that John borrows directly from the Wisdom myth. ${ }^{15}$ Dodd, Schnackenburg and Barrett argue that the evangelist synthesised elements of Rabbinic and of Hellenistic Jewish thought. ${ }^{16}$ It seems most reasonable to assume that, given 'the easy give-and-take of...intellectual life' of the period, the latter hypothesis is more likely to be true. This means that by the word of God, the evangelist describes a divine hypostasis through which an otherwise transcendent God reveals himself in the temporal order of human existence.

In his commentary on the gospel of John (1964), Rudolf Bultmann argues that the evangelist's description of the logos as an incarnate redeemer is indebted to Gnosticism, the amorphous group of syncretic religious systems described by St. Irenaeus (c. 130-c. 200) and St. Hippolytus (c. 170-c. 236). ${ }^{17}$ All Gnostic thought was dualist, distinguishing sharply between the spiritual and material orders, and regarding the latter as evil. Most systems had a series of mediators between God and the material world, which were instruments of its creation and which descended into it to reveal God and to make a way for men to ascend to Him. These figures have a series of names, including huios theou (son of God), monogenês (only-begotten), and eikôn tou theou (image of God). Bultmann hypothesises that the evangelist used an early oriental Gnostic source, in which the Logos was the only mediator between God and the world. ${ }^{18} \mathrm{He}$ writes, "The central theme of the Gnostic redeemer-myth is that a divine being, the Son of the Highest, assumed human form... in order to bring revelation and redemption' 19

\footnotetext{
${ }^{15}$ Haenchen, John p. 139.

${ }^{16}$ Dodd. Fourth Gospel p. 280; Schnackenburg, St. John p. 493; Barrett, St. John p. 154-155.

${ }^{17}$ See Dodd. Fourth Gospel pp. 97-114; J.N.D. Kelly, Early Christian Doctrines, $5^{\text {th }}$ ed. (London: A. \& C. Black, 1977) pp. 20-28.

${ }_{18}^{18}$ Bultmann, John p. 29.

${ }^{19}$ Ibid. p. 61.
} 
In the source used by John, according to Bultmann, this was the role of the Logos.

Most commentators now disagree with the hypothesis of a Gnostic source, but Bultmann's existentialist exegesis nevertheless provides a useful interpretation of the evangelist's concept of the divine word. He stresses the revelatory function of the Logos and the consequence of this for our knowledge of God. He writes, 'The idea of God is determined... by the idea of revelation. To speak of God means: to speak of his revelation; and to speak of his revelation means: to speak of God'. ${ }^{20}$ The Logos, that is, is God insofar as He reveals himself. Bultmann stresses the inaccessibility of God to human knowledge suggested in the verse, "No-one has ever seen God. It is God the only son, who is close to the father's heart, who has made him known' (Jn. 1:18). This means that God cannot be an object of knowledge, nor thought of 'in himself'. Bultmann writes, 'God ceases to be God if he is thought of as an object'. ${ }^{21}$ He is known only insofar as he reveals himself. This revelation, Bultmann stresses, takes place in humanity. Expounding Jn. 1:14, 'The word became flesh [ho logos sarx egeneto]', he writes, 'It is in his sheer humanity that he is the Revealer'. Sarx (flesh) denotes the transitory and vain qualities of the worldly sphere. When the evangelist continues, 'We have seen his glory [doxa]', Bultmann writes, 'The doxa is not to be seen...through the sarx, as through a window; it is to be seen in the sarx and nowhere else'. ${ }^{22}$ In Bultmann's exegesis, the divine word is a hypostasis through which God reveals himself in the order of human existence, and through which alone he is known in that order.

\footnotetext{
${ }^{20}$ Tbid. p. 35 .

${ }^{21}$ Ibid. p. 81 .
} 


\section{Adam's Names}

The Bible describes the origin of human language at Gen. 2:19:

Out of the ground the LORD God formed every animal of the field and every bird of the air, and brought them to the man to see what he would call [yiqra'] them; and whatever the man called every living creature, that was its name [shem].

From the sixteenth to the eighteenth centuries, linguists saw in this verse a description of an original language given to Adam by God. ${ }^{23}$ As Michel Foucault writes, in The Order of Things (1966), this language was conceived as 'an absolutely certain and transparent sign for things, because it resembled them'. ${ }^{24}$ Traces of this transparency remained in the Hebrew language. In his commentary on Genesis (1956), Gerhard von Rad argues that today, 'we are not dependent for an explanation on the primitive view of the connection between a name and its bearer'. ${ }^{25}$ What he sees described in these verses is the development of language as a human means of interpreting the world. He writes that the naming is 'both an act of copying and an act of appropriative ordering', by which man makes sense for himself of the chaotic mass of forms that impinge upon his senses. ${ }^{26}$ In his Old Testament Theology (1960), he links this to the ancient idea of the power of mastery attached to names. He writes, "It was only when man gave the animals their names that they existed for him and were available for his use ${ }^{27}$ In Orality and Literacy (1982), Walter J. Ong points out that the idea of power in naming is less archaic than it can seem. He writes, 'Without learning a

\footnotetext{
22 Thid. p. 63.

${ }^{23}$ See Hubert Bost. Babel: Du Texte au Symbole, (Geneva: Labor et Fides, 1985) pp. 167-174.

${ }^{24}$ Michel Foucault, The Order of Things: An Archaeology of the Human Sciences, tr. from the French (London: Tavistock, 1970) pp. 34-42.

${ }^{25}$ Gerhard von Rad, Genesis: A Commentary, $2^{\text {nd }}$ ed, tr. John H. Marks (London: SCM, 1963) p. 80.

${ }^{26}$ Ibid. p. 81 .

${ }^{27}$ Von Rad, Old Testament Theology Vol. II p. 81.
} 
vast store of names, one is simply powerless to understand, for example, chemistry and to practice chemical engineering,. ${ }^{28}$ Claus Westermann, in his commentary on Genesis (1976), follows von Rad's exegesis. He understands the description of God's bringing the animals to the man to mean that 'man is autonomous within a certain limited area' ${ }^{29}$ Man must accept the created world as it has been created, but he can determine his relationship to it. Westermann sees this as an explanation by the Yahwist of the Priestly source's assertion in Gen. 1:26 and 1:28 that God appointed man master of the animals. For Westermann, this means that by devising names for them man determines their place in his world. He writes, 'By naming the animals the man opens up, determines and orders his world and incorporates them into his life. The world becomes human only through language'. ${ }^{30}$ This is a fair interpretation. We can take Gen. $2: 19-20$ to mean that language is a means by which man makes himself at home in the world. Finding themselves in a world not of their own making, people divide their experience into discrete parts by means of names in order to make it comprehensible. This gives them an increasing amount of power over this experience.

\section{The Tower of Babel}

The nature and value of this power is elaborated in the story of the Tower of Babel, at Gen. 11:1-9. It was clearly composed from several different sources, which the Yahwist has formed into a consistent whole. One of the elements

\footnotetext{
${ }^{28}$ Walter J. Ong, Orality and Literacy: The Technologizing of the Word (London and New York: Methuen, 1982) p. 33.

29 Claus Westermann, Genesis 1-11: A Commentary, $2^{\text {nd }}$ ed, tr. John J. Scullion (London: SPCK. 1984) p. 228.
} 
incorporated into the story is an aetiology of the diversity of languages. It runs as follows:

The whole earth had one language [saphah, lit. 'lip'] and the same words [devarim]... [The people] said, 'Let us build ourselves a city, and a tower with its top in the heavens, and let us make a name [shem] for ourselves'... Yahweh said... 'They are all one people and they have all one language; ;... nothing they propose to do will now be impossible for them... Let us go down and confuse their language... so that they will not understand one another's speech [saphath]'. So Yahweh scattered them abroad from there over...all the earth...[The city] was called Babel because there Yahweh confused [balal] the language of all the earth.

The story comes at the end of the Bible's 'primeval history', Gen. 1-11. The genealogy of Shem that follows in $11: 10-27$ provides the link to Abraham, with whom the patriarchal history begins in Chapter $12 .^{31}$ Westermann writes that, in contrast to the latter, the primeval history '[looks] to the universal; [it] includes all humanity; and primeval time in which all takes place cannot be fixed on the calendar ${ }^{32}$ Hence the subject of the story of Babel is humankind in general, and 'the basic motif is world wide'. ${ }^{33}$ It is one of the 'narratives of crime and punishment' which, together with creation stories and genealogies, comprise the whole of the primeval history. The Yahwist uses these stories for an aetiological purpose. Westermann writes, 'Their intention is to explain something of the negative side of human existence by means of a punishment caused by a revolt ${ }^{34}$ The negative experience in the story of Babel is that of the diversity of languages. Westermann writes, 'It was the common experience of humanity at an early stage that the multiplicity of languages was not natural', citing parallel stories concerning the confusion of languages. ${ }^{35}$ Gen. 11:1, "The whole world

\footnotetext{
${ }^{30}$ Westermann Genesis 1-11 pp. 228-229.

${ }^{31}$ See Von Rad. Genesis pp. 148-150.

${ }^{32}$ Westermarn Genesis 1-11 p. 4.

${ }^{33}$ Ibid. p. 542.

${ }^{34}$ Tbid. p. 53.

${ }^{35}$ Ibid. pp. 537-9.
} 
had one language', is misconstrued as a historical statement, since historical reference is not a concern of the genre of which the verse is a part. Westermann describes it rather as 'a hypothesis to which one concludes from the unnatural present situation', of which alone human memory has experience. ${ }^{36}$

The story in its present form concerns a kind of sin of pride. There is a parallel to the story in Isa. 14:13-14, where the prophet says of the king of Babylon:

You said in your heart, 'I will ascend to heaven;

I will raise my throne above the stars of God...

I will ascend to the tops of the clouds, I will make myself like the Most High.'

Here the ambition expressed in a high Babylonian building is equated with the desire to become like God. The same is suggested at Jer. 51:53, "Though Babylon should mount up to heaven, and though she should fortify her strong height... It It thus seems reasonable to connect the sin of the builders with the temptation of Eve at Gen. 3:5, where the serpent tells her that she 'will be like God'. These passages occur at the beginning and at the end of the primeval history, with the pattern enacted first by individuals and then by humankind in general. Westermann argues that this is intended to express that human beings are capable of overstepping the limits of their created state. He writes, 'In J's understanding of humanity... humans are to remain within the limits assigned to them. Here alone can their existence find fulfilment'. ${ }^{37}$ It seems reasonable to connect the confusion of languages with the builders' motivation to 'make a name' for themselves, since both pertain to language. Umberto Cassuto and Westermann argue that there is nothing inherently reprehensible in this desire,

\footnotetext{
${ }^{36}$ Tbid. p. 542.

${ }^{37}$ Ibid. p. 555.
} 
citing a series of passages in which the construction occurs. ${ }^{38}$ Nevertheless, in each of these passages, Yahweh is the one who makes a name for himself, by salvific action on behalf of Israel. This is directly the case in Isa. 63:12, Jer. 32:20, Neh. 9:10 and 2 Sam. 7:23; and in Gen. 12:2, Yahweh makes a name for Abraham. Making a name for oneself is clearly the prerogative of Yahweh. The builders' attempt to do so represents a failure to respect their creaturely status. The Targum expresses this by replacing the words 'Let us make a name for ourselves' with 'Let us make an idol at [the tower's] summit and place a sword in its hand'. ${ }^{39}$ This suggests that the 'name' described in Gen. 11:4 describes a kind of language-use contrary to the will of God, which represents an overstepping of mankind's creaturely status.

The structure of the story suggests the nature of this kind of language in its combination of elements concerning the diversity of languages with elements concerning the diversity of societies. The connection between the two is most pronounced in the divine monologue at 11:6: 'They are one people and they have all one language'. The story suggests that language is instrumental in the structure of society. It allows people to work together in communities, and this work can be for good or for evil. We have indicated the connection between naming and power in the Old Testament. The story of Babel suggests that a significant part of this power is social. As Walter Brueggemann writes in his commentary on Genesis (1982), 'Language shapes the ways in which human communities...arrange power' ${ }^{40}$ The divine reflection that 'this is only the beginning of what they.will do; nothing... will now be impossible for them'

\footnotetext{
${ }^{38}$ Umberto Cassuto, 4 Commentary on the Book of Genesis Vol. II, tr. Israel Abrahams (Jerusalem: the Magnes Press, 1964) p. 243; Westermann, Genesis 1-11 p. 548.

39 Targum Neofiti 1: Genesis, tr. Martin McNamara (Edinburgh: T. \& T. Clark, 1992) p. 84.

${ }^{40}$ Walter Brueggemann, Genesis (Atlanta: John Knox Press, 1982) p. 102.
} 
indicates the extent of the social aspect of the power of language. Since they incur Yahweh's punishment, we can assume that the builders represent a use of language contrary to his will. Since the unity of society is also part of the problem, it seems that the kind of language that forces society into a unity detrimental to many of its members is being described. This must be language which claims an authority to which it has no justifiable claim, that is, the language of ideology. Gen. 11:1-9 indicates that the power inherent in naming can be used to exploit others and the world, and that this practice is contrary to the will of God. Since this is an abuse of the social power of language, we can infer that the Bible's view of the proper end of language is the good of the society in which it is used.

\section{Pentecost}

Pentecost, the fiftieth day after Passover, was the Festival of Weeks of Lev. 23:15-21 and Deut. 16:9-12, as Tob. 2:1 makes clear. It was originally a harvest festival, also known as the 'day of the first fruits' (Num. 28:26). The Book of Jubilees 6:17-19 connects the feast to the covenant with Noah, and in later Judaism it became associated with the giving of the Law at Sinai. ${ }^{41}$ C.K. Barrett, in his commentary on Acts (1994), writes that the evidence of this development is too late to have influenced Luke, but Ernst Haenchen argues that despite this, the feast had 'doubtless already been transformed in people's minds into the feast of the lawgiving'. ${ }^{42}$ Certainly the 'sound', 'violent wind' and 'fire' (Acts

\footnotetext{
"11 See Leo O'Reilly, Word and Sign in the Acts of the Apostles: A Study in Lucan Theology (Rome: Editrice Pontifica Università Gregoriana, 1987) p. 18-21.

${ }^{42}$ C.K. Barrett, $A$ Critical and Exegetical Commentary on the Acts of the Apostles, Vol. I (Edinburgh: T. \& T. Clark, 1994) p. 111; Ernst Haenchen, The Acts of the Apostles: A
} 
2:2-3) which accompany the disciples' filling with the Holy Spirit are elements of Old Testament theophanies, the last in particular associated with the revelation of the Law at Sinai (Ex. 19:18, Deut. 4:12). In De Decalogo, Philo portrays the voice of God at Sinai visible as fire. ${ }^{43}$ A Rabbinic tradition concerning the giving of the Law held that the voice of God at Sinai divided into seventy voices, one for each of the nations of the world, as enumerated in Gen. 10. Although only Israel heard and accepted the Torah, it was heard by all nations in their own languages. ${ }^{44}$ Whilst this saying post-dates Luke, Haenchen argues that he was familiar with the tradition from which it evolved. In Word and Sign in the Acts of the Apostles (1987), Leo O'Reilly notes that the Targum to Deut. $33: 2$, in which the Law is communicated in several languages, indicates the age of the tradition. ${ }^{45}$

These parallels make it likely that Luke intends a comparison of the coming of the Holy Spirit to the giving of the Law. The tongues as of fire (glôssai hôsei puros) that split and rest over the disciples (v. 3) are reminiscent of the voice of God at Sinai. A Rabbinic tradition has fire resting on the heads of rabbis as they study and discuss the Torah. ${ }^{46}$ It seems reasonable to associate them with the 'other tongues' (heterais glôssais) in which the Spirit gives the disciples to speak (v. 4). Clearly Luke is portraying an event in which the word of God is given to all nations. He emphasises the tradition in which this was said already to have occurred at Sinai. The long list of nationalities in vv. 9-11 contains devout men 'from every nation under heaven' (apo pantos ethnous tôn hupo ton ourcanon).

Commentary, tr. Bernard Noble, Gerald Shinn and R. McL. Wilson (Oxford: Blackwell, 1971) p. 174.

${ }_{43}^{4}$ Philo of Alexandria. De Decalogo 46-48.

${ }^{44}$ Midrash Rabbah: Exodus V, 9. See Barrett, Acts p. 111; O’Reilly, Word and Sign p. 23.

${ }^{45}$ O'Reilly, Word and Sign p. 23.

${ }^{46}$ The Babylonian Talmud: Shabbath 88b. See Barrett. Acts p. 114. 
Luke records that 'each one heard them speaking in the native language [têi idiai dialektôi] of each' (v. 6). The miracle at Pentecost represents the word of God expressed in as many languages as there are people to hear. As Stanley Hauerwas writes in 'The Church as God's New Language' (1987), 'At Pentecost, God created...the miracle of being a people whose very differences contribute to their unity'. ${ }^{47}$ Despite many instances of cultural history to the contrary, the account of Pentecost indicates that the word of God and the language of ideology are mutually exclusive. Human language used according to the will of God aims at communication with the hearer in his or her individual humanity.

The account also suggests that experience of God transcends the limits of language. Just as at Sinai, what is expressed at Pentecost is God's salvific selfrevelation to mankind. The disciples speak of 'God's deeds of power' or 'great things' (ta megaleia tou theou), which we can take to be those on which Peter discourses in vv. 14-36, namely the crucifixion and resurrection of Christ. It seems reasonable to assume that the filling with the Holy Spirit described in v. 4 denotes an immediate experience of that which the disciples go on to proclaim, God's salvific will in Christ. Peter associates their speech with prophecy in $2: 17$ 18 , and Haenchen points out that apophtheggomai, the verb used in the phrase to 'speak in other tongues', denotes the solemn or inspired utterance characteristic of prophecy. ${ }^{48}$ The language miracle suggests that experience of 'the great things of God' is not adequately represented within the conceptual confines of any given language. We saw in Gen. 2:19-20 that the Bible portrayed language as a means by which people interpret the world in which they find themselves. Acts

\footnotetext{
${ }^{47}$ Garrett Green. ed., Scriptural Authority and Narrative Interpretation (Philadelphia: Fortress, 1987) p. 185.
} 
$2: 1-13$ suggests that the categories devised in this process cannot adequately represent the creator of that world. God cannot be understood by human thought and hence not denoted by human language.

What do these concepts of language expressed and implied by the Bible mean for Christian literary theory and criticism? We can take them to mean the following. The act of authorship is an imitation of God. The revelation of one's mind to others in external words is an analogy of God's revelation of himself to mankind by his Word, primarily in the creation and the Incarnation, which is to say that authorship is analogous to these events. The analogy is imperfect, however. Literary texts are not merely expressions of fully-formed thoughts, but a means by which the author attempts to understand the world of his or her experience and to make a home in it. Finally, the Bible suggests that literary works necessarily have social and political effects. Christian criticism must therefore assess and judge these effects. It will be attentive to the role of ideology in the production and reception of a work, as we discussed in Chapter 2 , and it might take as a standard of value the degree to which a work can be perceived, in terms of Christian social ethics, to benefit a given community of readers.

\section{Art in the Bible}

The Bible has no concept of fine art, that is, of works whose end is their own beauty. Art is mentioned in the Bible almost entirely in connection with places and acts of worship. The first extended treatment of the subject comes in Ex. 25-

\footnotetext{
${ }^{48}$ Haenchen, Acts p. 168.
} 
39, where Yahweh gives Moses instructions for building the tabernacle, which are then carried out. These chapters associate works of art with the presence of God. The purpose of the tabernacle is made clear in Ex. 25:8, where Yahweh says, "Have them make me a sanctuary so that I may dwell among them". In Ex. 24:16-18 the glory (kebod) of Yahweh is described as settling on Mount Sinai, and in Ex. 40:34, 'The glory of Yahweh filled the tabernacle'. As Brevard S. Childs writes in his commentary on Exodus (1974), 'The presence of God which had once dwelt on Sinai now accompanies Israel in the tabernacle'. ${ }^{49}$ The closest object to a work of fine art prescribed for this place is the sculpture of two cherubim that form one piece with the 'mercy seat', or lid, of the ark of the covenant. $^{50}$ In Ex. 25:18-20, Yahweh tells Moses that they are to be made of hammered gold, and to face one another 'overshadowing the mercy seat with their wings'. He says, 'There I will meet with you, and from above the mercy seat, from between the two cherubim...I will deliver to you all my commands' (v. 22). This promise is fulfilled in Num. 7:89: 'When Moses went into the tent of meeting to speak with Yahweh, he would hear the voice speaking to him from...between the two cherubim'. This art-work stands in the very place of Yahweh's presence to Israel. It is put in the 'most holy' part of the tabernacle (Ex. 26:34), and Yahweh speaks from its midst. We can take this to indicate that art works have a sacred character. Although we cannot say that the mercy-seat is representative of art-works in general, the text suggests that such works are, at

\footnotetext{
${ }^{49}$ Brevard S. Childs, Exodus: A Commentary (London: SCM Press, 1974) p. 536.

${ }^{50}$ The word 'mercy-seat' transiates the Hebrew kapporet, which derives from a root originally meaning 'to cover', but used mainly in the Old Testament with the sense 'to absolve'. The Septuagint and Vulgate translations retain the sense of 'mercy', as do Luther's translation and the Authorised Version. J. Philip Hyatt, in Commentary on Exodus (London: Oliphants. 1971) pp. 266-267, and Martin Noth, in Exodus: A Commentary, tr. J.S. Bowden (London: SCM, 1962) pp. 204-205, agree that the sense simply of 'covering' is the most likely. Cherubim are imaginary creatures with human faces, wings and the body of an animal. Hyatt writes, "They were widely known in Mesopotamia as guardians of temples and palaces' (Exodus p. 267).
} 
least potentially, both acts of worship of God and symbols or representations of his presence.

Ex. 31 and 35:30-36:1 describe artistic skill as a charism from God. Yahweh designates two artisans to supervise the construction of the tabernacle, who are described as follows:

See, I have called by name Bezalel, son of Uri... of the tribe of Judah, and I have filled him with divine spirit [ruach elohim], with ability, intelligence and knowledge in every kind of craft, to devise artistic designs in...every kind of craft... I have appointed with him Oholiab, son of Ahisamach, of the tribe of Dan (Ex. 31:1-6).

Yahweh's 'call by name' indicates an intimacy of relationship to Him in the recipient, as in Isa. $43: 1 ; 45: 3-4$; Ex. $33: 17$. Bezalel stands in this relationship to God in his capacity as an artisan. As George Knight writes in his commentary on Exodus (1976), 'The artisan is... as much elect to serve God's plan as is the prophet and the priest' ${ }^{51}$ Bezalel's skill is described as a direct result of the action of the 'divine spirit'. This is also said of every worker who assists the two masters. Ex. 36:1 describes 'every skilful one to whom Yahweh has given skill and understanding to know how to do any work'. This suggests that all artistic skill is a gift from God. In his Theology of the Old Testament (1964) Walther Eichrodt describes the spirit of God, with which Bezalel is filled, as 'the medium through which God's presence in the midst of his people becomes a reality'. ${ }^{52}$ This accords with the function of art in the tabernacle. The art-works produced as a result of Bezalel's inspiration are mediations of the presence of God. This is reinforced in the Bible's other extended discussion of the plastic arts, 1 Kings 68 , where Solomon builds the Temple in Jerusalem, which replaces the tabernacle

\footnotetext{
${ }^{51}$ George A.F. Knight, Theology as Narration: A Commentary on the Book of Exodus (Edinburgh: Handsel, 1976) p. 182.

${ }^{52}$ Walther Eichrodt. Theology of the Old Testament, Vol. II, tr. John Baker (London: SCM, 1967) p. 61 .
} 
as the dwelling of Yahweh in Israel. The Bible describes art as a divine charism, and suggests that the works it enables its recipients to produce are symbols in the community of God's presence there.

It is possible, in the Biblical view, to use this skill both for and against God's will, as the forging of the golden calf in Ex. 32:2-4 indicates. The commandment against images is repeated eight times in the Pentateuch. Ex. 20:4-5 reads:

You shall not make for yourself an idol [pesel], whether in the form [temunah] of anything that is in heaven above or that is in the earth beneath... You shall not bow down to them or worship them; for I, the LORD your God am a jealous God.

The word pesel refers to an image carved in wood or stone, and later came to refer to metal figures also. ${ }^{53}$ As Martin Noth writes in his commentary on Exodus (1962), 'The possibility of a merely ornamental art is surely not envisaged', since the commandment concerns worship. ${ }^{54}$ Since the previous commandment has forbidden other gods, it seems that 'originally the prohibition concerned Yahweh images', and that a later redaction widened its scope to include images of other gods. ${ }^{55}$ Wis. 13-15 and Isa. 40:19-20 describe and condemn the fashioning of such idols by artisans. When the Bible describes the beauty of an art-work enjoyed in itself, it is always in the context of idolatry, as in Wis. 14:20 and Isa. 41:7. Wis. 15:4-5 describes 'human art...whose appearance arouses yearning in fools, so that they desire the lifeless form of a dead image'. Both making and perceiving works of art, in the Old Testament view, are properly acts of worship of Yahweh. Outside this context, they are simply misused.

\footnotetext{
${ }^{53}$ Childs, Exodus p. 404.

${ }^{54}$ Noth, Exodus p. 162.

${ }^{55}$ Childs, Exodus pp. 405-6.
} 
The Bible also sees music and song as acts of worship. In $1 \mathrm{Chr}$. 6:31-48, the singers and musicians whom David appointed to minister before the ark of the covenant which he had brought to Jerusalem - Heman, Asaph and Ethan - are all traced genealogically back to Levi. The Pentateuch describes Yahweh's appointment of the tribe of Levi as his ministers. 'The LORD set apart the tribe of Levi to carry the ark of the covenant of the LORD, to stand before the LORD to minister to him... to this day' (Dt. 10:8-9). 'The LORD ... has chosen Levi out of all your tribes to stand and minister in the name of the LORD...for all time' (Dt. 18:5. See also vv. 1-8; Num. 8:5-26). Num. 18:1-7 describes the Levites in general to be in the service of that line of the tribe which descends from Aaron, the priests, and the Chronicler maintains the distinction between the two groups (1 Chr. 6:49-53). ${ }^{36}$ Singing and making music are thus represented as specifically priestly functions by the Chronicler. 1 Chr. 15:16-24 and 16:4-7 describe in some detail the various kinds of instruments and music played by the Levites before the ark. As with the construction of the tabernacle, these passages indicate the sacred character of music. It is seen as a form of worship of God, and as a priestly work. It is associated with the ark of the covenant, and so with God's presence to Israel. In $2 \mathrm{Ki}$. $3: 15-16$, Elisha begins to prophesy to the sound of music:

While the musician was playing, the power of the LORD came on him. And he said, 'Thus says the LORD...'

The Bible sees music, like the plastic arts, both as an act of worship and as a means by which God can be revealed in the community.

\footnotetext{
${ }^{56}$ See R.J. Coggins, The First and Second Books of the Chronicles (Cambridge: Cambridge University Press, 1976) pp. 45-46, and Sara Japhet, Chronicles: A Commentary (London: SCM Press, 1994) pp. 149-165.
} 
There are several principles in the Bible's treatment of art that we can use in Christian literary theory today, if we can legitimately predicate of literary texts the qualities with which the Bible describes works of plastic and musical art. We can take from the Bible the idea that the production of fictional works in general is a charism, an effect of the presence of the Holy Spirit in an author. The reception of such works can, as a result, be thought of as a kind of worship, however unconscious, insofar as some texts can for some readers symbolise or represent the immanent presence of God in the world. I will suggest in more detail how this might be the case in the next chapter, but we can note here that the Bible provides the basis for a Christian theory of literary value insofar as it distinguishes between works which are associated with the presence of God and works which take the place of God. A valuable text, it suggests, is one in which a reader experiences in some way something of the divine mystery of his or her experience.

\section{(ii) St. Augustine}

St. Augustine, 'the greatest of the Fathers both from a literary and from a theological standpoint', dominated the Christian theology and philosophy of the West until the rediscovery of the works of Aristotle in the twelfth century. ${ }^{57}$ In his Studies in Tertullian and Augustine (1930), B.B. Warfield writes:

\footnotetext{
${ }^{57}$ F.C. Copleston, A History of Philosophy Vol. II: Medieval Philosophy, Augustine to Scotus (London: Burns. Oates and Washbourne, 1950) p. 40.
} 
The Western church has felt the force of his influence in all the main lines of its development, and in no one of its prominent characteristics could it have been without him what it has become. ${ }^{58}$

Augustine had been a teacher of rhetoric before his conversion, and his thought remained deeply informed by his acquaintance with the liberal arts.

\section{St. Augustine's Theory of Signs}

In Semiotics and the Philosophy of Language (1984), Umberto Eco argues that Augustine was the first to consider language as a species of the genus of signs. ${ }^{59}$ The Stoics had associated language with signs by considering both as parts of dialectic. In his life of Zeno (c. 250), Diogenes Laertius writes that one Stoic account of the subject of dialectic was 'signs and things signified', and he calls this their 'theory of language [tê peri phônês theôria]'. ${ }^{60}$ Sextus Empiricus tells us that the Stoic definition of a sign was as 'an antecedent proposition in a valid hypothetical major premise, which serves to reveal the consequent ${ }^{261}$ In the premise, 'If there is smoke, then there is fire', the proposition (caxioma) 'there is smoke' is a sign (semeion) of the proposition 'there is fire'. The Stoics thought of statements as signs. As Diogenes Laertius writes, 'Speech [lexis] differs from a sentence or statement [logos] because the latter always signifies something [sêmantikos esti] ${ }^{62}$ St. Augustine differs from the Stoics by thinking of words as signs. ${ }^{63}$

\footnotetext{
${ }^{58}$ Benjamin Breckenridge Warfield, Studies in Tertullian and Augustine (New York: Oxford University Press, 1930) p. 120.

${ }^{59}$ Umberto Eco, Semiotics and the Philosophy of Language (London: Macmillan. 1984) p. 33.

${ }^{60}$ Diogenes Laertius, Lives of the Eminent Philosophers VII, 62.

${ }^{61}$ Sextus Empiricus, Against the Logicians II, 245. Sec also Outlines of Pyrrhonism II, 104-106.

${ }^{62}$ Diogenes Laertius, op. cit. VII, 57.

${ }^{63}$ In 'St. Augustine on Signs', Phronesis 2 (1957), R.A. Markus argues that Augustine thought of words as signs in order to devise a theory of Scriptural signs (p. 65). In 'Les Origines Stoïciennes de la Théorie Augustinienne du Signe', Révue des Etudes Latines 59 (1981) pp. 260-268, Marc
} 
He establishes the context of semiosis in De Genesi contra Manichaeos (388390). Before the fall, Augustine writes, God was directly present to the human intellect. Man needed no 'exterior words' to communicate with God, but knew Him through 'the immanent presence of truth' to his intellect. ${ }^{64}$ After the fall, the soul was no longer watered by this inner spring, but needed 'to be taught by human words' in order to know God. ${ }^{65}$ In the next life, Augustine writes, the science of interpreting these words will become unnecessary, because we will see God face to face. ${ }^{66} \mathrm{He}$ argues that in the 'transparency and simplicity' of the celestial body, the movements of the soul will be immediately apparent, and incapable of being hidden, as in our mortal bodies. ${ }^{67}$ Lying and all misunderstanding, which will then be impossible, are a direct result of the mortality of the flesh' with which the human race was punished after the fall. ${ }^{68}$ In the Confessions (397), Augustine understands the sea-creatures of Gen. 1:22 to refer to the 'physical signs and manifestations', which we need to use because 'the flesh which envelops us is like a deep sea'. ${ }^{69}$ Symbolic activity, for Augustine, is necessary because of our fall into a state in which our senses are not properly subordinated to our intellect, whose contemplation of God constitutes our happiness.

\footnotetext{
Baratin suggests a more convincing reason for the change of emphasis. Diogenes Laertius tells us that the Stoics distinguished between phônê or vocal utterance, lexis or articulate but not necessarily meaningful utterance, and logos or meaningful utterance (Lives VII, 57). Baratin argues that the Alexandrian grammarians redefined the grammatically useless term lexis so that it denoted the smallest element of a significant utterance, a word. He cites Dionysius Thrax, Grammatici Graeci I, 1. Baratin argues that Augustine was familiar with this redefinition of the Stoic system.

${ }^{64}$ De Genesi contra Manichaeos $\Pi$. iv, 5.

${ }^{65}$ Ibid. II, v, 6.

${ }^{66}$ Ibid.

${ }^{67}$ Ibid. II, xxi. 32.

${ }^{68} \mathrm{Ibid}$.

${ }^{69}$ Confessiones XIII, xxiv, 37.
} 
For St. Augustine, the intellect is superior to the bodily signs we use to make known its operations. It knows eternal truths, which are of greater value than the temporal objects known by the senses. In De Catechizandis Rudibus (c. 400405), Augustine writes that, as a result, it is difficult to translate thought into speech. He writes, 'When my capacities of expression prove inferior to my inner apprehensions, I grieve over the inability which my tongue has betrayed in answering to my heart' ${ }^{70}$ This is because the process of forming a concept is 'something like a rapid flash [quasi rapida cornscatione]', whereas speech is protracted in time, and of a 'vastly different nature' to understanding. ${ }^{71}$ As Augustine writes in De Fide et Symbolo (393), 'Between mind and body there is the greatest difference' ${ }^{72}$ When we speak, we are attempting to transfer into the mind of another the understanding of our own mind by bodily means. Because of the gulf between the two, 'the mind of the speaker cannot become perfectly known' ${ }^{73}$ Even the traces of understanding in our memory exist in the mind and so are altogether different to bodily signs. ${ }^{74}$ Sometimes, Augustine continues, we can try so hard to convey our understanding that the very fervour of the attempt (ipsam intentionem) prevents us from doing so. ${ }^{75}$

In De Doctrina Christiana (396-426), Augustine defines a sign as 'a thing which causes us to think of something [in cogitationem venire] beyond the impression [speciem] the thing itself makes upon the senses ${ }^{76}$ Strictly speaking, a thing (res) is 'that which is not used to signify something else', ${ }^{77}$ So every sign is also a thing, although not every thing is a sign. As Augustine writes in $D e$

\footnotetext{
${ }^{70}$ De Catechizandis Rudibus ii, 3.

${ }^{11}$ lbid.

${ }^{12}$ De Fide et Symbolo iii, 4.

${ }^{73}$ Ibid.

${ }^{74}$ De Cat. Rud. ii. 3.

${ }^{75}$ Ibid.
} 
Dialectica (387), 'words are signs of things without ceasing to be things' ${ }^{78}$

Signs can be divided into two kinds, natural (naturalia) and given (data) signs, according to whether or not they are produced by the will. ${ }^{79}$ The former arise 'without any desire or intention of signifying', as when smoke signifies fire. The latter, Augustine writes, are:

those which living creatures show to one another for the purpose of conveying, insofar as they are able, the motion of their spirits [motus animi] or something which they have sensed or understood...[They are used for] bringing forth and transferring to another mind the action of the mind in the person [id quod animo geril] who makes the sign. ${ }^{80}$

Among given signs, words have come to be predominant among men. ${ }^{81}$ In $D e$ Dialectica, Augustine distinguishes four elements in the class of verbal signs. There is the thing (res), sensed or understood. If this thing is a word, as when we discuss words, then it is a verbum, or 'mention'. A word spoken to signify something other than itself Augustine calls a dictio. Finally, there is the dicibile, which is 'that which the mind not the ears perceives from the word and which is held within the mind itself' ${ }^{82}$ It is the 'meaning' of a word, the concept its speaker means to express by it. He 'bears it in his mind', and aims to transfer it into the mind of his hearer by means of his bodily words.

Augustine elaborates his theory of meaning most fully in De Trinitate (400417). He writes that a word can be understood before it is uttered aloud and even before the images of its sounds are rehearsed in thought. This is the "word

\footnotetext{
${ }^{76}$ De Doctrina Christiana II, i, 1.

${ }^{77}$ Ibid. I, ii, 2.

${ }^{78}$ De Dialectica $\mathrm{v}$.

${ }^{79}$ De Doct. Chr. II, i, 2. As B. Darrell Jackson points out in 'St. Augustine's Theory of Signs in De Doctrina Christiana', Révue des Etudes Augustiniennes 15 (1969) p. 14, signa data is mistranslated as 'conventional signs'. The difference between natural and given signs is the absence and presence of will in them.

${ }^{80}$ De Doct. Chr. II, ii, 3.

${ }^{81}$ Ibid. II, iii, 4.

${ }^{82}$ De Dial. v.
} 
spoken in our heart [verbum ... quod in corde dicimus] ${ }^{83}$ When we speak of what we know, Augustine writes:

There must be born out of the knowledge held in our memory a word which corresponds in all respects to the knowledge of which it is born. The thought [cogitatio] which has received form from the object of our knowledge is the word spoken in our heart. ${ }^{84}$

When we see a bodily object, in Augustine's view, the sense of sight receives the form of the object's outward appearance. ${ }^{85}$ In the same way, when we think of something that we know, our internal vision receives the form of the image of the thing known, stored in our memory. ${ }^{86}$ Internal vision so informed he calls cogitatio, or conscious thought. The form of the thing known in the internal vision he calls the word of the heart. This is because in the inward realm of our thoughts, [locution and vision] are one and the same' ${ }^{87}$ In the process of coming to know something, a 'darting movement of passage in the mind' lights upon the image of a sensible object or upon a universal truth in the memory, receives its form, and becomes a 'true word' of knowledge. ${ }^{88}$ This is what verbal signs signify. 'The word in its outward sounding', to which we usually give the name of word, is a 'bodily sign' of the 'word that is inwardly luminous' ${ }^{89}$ It does not represent the inner word 'as it is truly is, but in the manner in which it may be seen or heard through the medium of the body', ${ }^{90}$ Augustine likens the process of signification to the Incarnation:

We may compare the manner in which our own word is made as it were a bodily utterance... as a means of displaying itself to men's senses, with

\footnotetext{
${ }^{83}$ De Trinitate XV, $\mathrm{x}, 19$.

84 Ibid.

85 lbid. XI. ii, 5.

86 Ibid. XI. iii. 6.

${ }^{87}$ Ibid, XV, X. 18.

${ }^{88}$ Ibid. XV, xV, 25; XV, xii, 22.

${ }^{89}$ lbid. XV, xi. 20

90 Ibid.
} 
that in which the Word of God was made flesh... as a means of displaying himself to men's senses. ${ }^{\text {I }}$

Just as the Word did not become the flesh he assumed, so our inner word does not become the sounds it assumes, but remains unchanged in itself, in the same way that the Word remained unchanged when incarnate. ${ }^{92}$

In De Magistro (389), Augustine discusses the role played by words in imparting knowledge. He argues that, 'Nothing is learned even by its appropriate sign', which means that, 'We learn nothing by means of these signs we call words ${ }^{93}$ Until I know the thing of which a word is the sign, I do not know that it is a sign at all. As a result, we should say that signs are learned from things, rather than vice versa. I only come to learn something if I perceive it with my eyes, with one of my other senses, or with my mind. I know sensible things either by sensing them or by having once done so, so that images of them are imprinted in my memory. When I express these images in words, no-one can understand the words' meaning unless he has similar images in his own memory. $\mathrm{He}$ 'recognises the truth of what I say by [these] images'. ${ }^{94}$ We know intelligible things by "looking upon them directly in the inner light of truth which illumines the inner man'. ${ }^{95}$ This inner light is divine. In the Soliloquies (386), Augustine writes:

The mind has, as it were, eyes of its own, analogous to the soul's senses. The certain truths of the sciences are analogous to the objects which the sun's rays make visible... It is God himself who illumines all. ${ }^{96}$

For St. Augustine, God is like an intelligible sun which enables the mind to see intelligible objects. The comparison came to him from Plato, by way of

\footnotetext{
91 Ibid.

${ }^{92}$ See De Doct. Chr. I, xiii, 12.

${ }^{93}$ De Magistro x, 33-34.

94 Ibid. xii, 39.

95 Ibid. xii, 40.

${ }^{96}$ Soliloquia I, vi, 12.
} 
Plotinus. ${ }^{97}$ If a pupil does not know whether what his teacher has said is true, he learns nothing from him. If the pupil recognises either that the teacher has spoken truly or falsely, this recognition cannot derive from the teacher's words, since these are susceptible both of truth and of falsity. The pupil has judged what he understands to be his teacher's concepts by an inner standard of truth, possessed by all. Augustine writes, 'When I speak what is true, and [the hearer] sees what is true... he is taught not by my words but by the things themselves which inwardly God has made manifest to him ${ }^{9}{ }^{98}$ If I tell him that seven and three make ten or that wisdom is better than folly, he looks within himself and discovers that it is true. The intelligible light of God in his mind illuminates the concepts and enables him to see their truth. Hence, as Scripture says:

Our real Teacher is he who is listened to [within], who is said to dwell in the inner man, namely Christ, that is, the unchangeable power and eternal wisdom of God. ${ }^{99}$

Augustine grants that 'when words are heard by one who knows them, he can also know that the speaker has thought the things which the words signify. ${ }^{100}$ But the words do not teach him anything. They simply prompt him to look within himself, either for traces of sensible knowledge in his memory or for intelligible knowledge in the inner light of his mind. Augustine writes, 'The utmost value I can attribute to words is this. They bid us look for things [admonent ... ut quaeremus res] ${ }^{101}$

We are bidden to look for the things the speaker intends us to know only insofar as we understand his intention by means of his words. As a result of their bodily nature, words often fail to convey this intention precisely. We can make

\footnotetext{
${ }^{97}$ See De Civitate Dei $\mathrm{X}$.ii.

${ }^{98}$ De Mag. xii, 40.

${ }^{99}$ Ibid. xi, 38.

${ }^{100}$ Ibid. xiv, 45.
} 
slips of the tongue, we can hear incorrectly, and the meaning we intend to convey in our words can be misunderstood. ${ }^{102}$ This last happens as a result of 'the hindrances... which come from the force of words [ex hac verborum vi...impedimenta]', namely their obscurity (obscuritas) and their ambiguity (ambiguitas). ${ }^{103}$ Words are obscure when their receiver does not know their meaning. This can be remedied by clear pronunciation and simple vocabulary in speakers and by a knowledge of languages and of the liberal arts in hearers. ${ }^{104}$ Ambiguity is more difficult to remedy. 'Every word is ambiguous', either univocally, if its definition includes different concepts, or equivocally, if it must be defined in different ways. ${ }^{105}$ The word 'Tullius' is equivocal, since its definition can be 'a name by which a man is signified', 'the greatest orator', 'a dactylic foot' or even 'an equivocal'. ${ }^{106}$ In equivocals, Augustine writes, 'The tangle [perplexio] of ambiguities runs wild, almost without limits [prope infinita]' ${ }^{107}$ When he discusses equivocals whose different definitions nevertheless derive from the same source, he writes, 'to pursue and defeat... this kind of ambiguity is an endless [infinitum] task' ${ }^{108}$ In De Dialectica, he does not claim to have succeeded in the task, but leaves that judgement to his reader. ${ }^{109}$ In De Doctrina Christiana, he comes to the similar conclusion that the ambiguities which arise from figurative expressions (locutiones figuratae) are in the end impossible fully to resolve. Having expounded Tyconius' seven rules for interpreting figurative expressions in Scripture, Augustine writes:

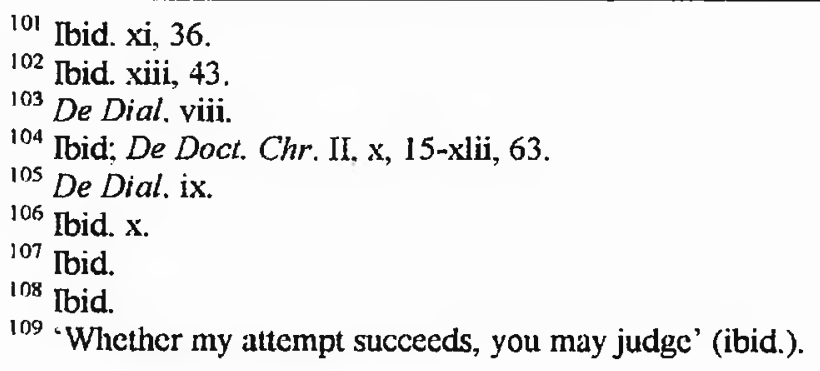


The scope of such expressions, it seems to me, is too broad for any one man to comprehend entirely [ab aliquo universa comprehendi]. ${ }^{110}$

There are so many ways in which one thing is understood from another that the art of rhetoric cannot categorise them all. When considered alone or in a written text, whose author cannot answer our questions, it may finally prove impossible to determine the meaning a word or phrase was intended to express. This is as the

true of the Scriptures as of any other text. It may be ${ }_{\wedge}$ case that "what he who wrote the passage intended remains hidden'.111 Augustine writes of the book of Genesis:

When so many meanings can be extracted from the words that Moses wrote, do you not see how foolish it is to make a bold assertion that one in particular is the one he had in mind? ${ }^{112}$

The ambiguities of words can be resolved when the hearer is face to face with the speaker, however. Although every word taken in itself is ambiguous, Augustine writes, 'ambiguities are explained through discussion [disputando]... by words already combined which will not be ambiguous'. ${ }^{113}$ The purpose of speaking is to transfer the concepts in our minds into the mind of another, and our presence to one another allows a reciprocal process of definition that makes this transfer as accurate as possible. As we saw, the gulf between mind and body is such that the correspondence between the speaker's and the hearer's understanding will never be perfect. In fact, it is achieved most fully by love, since, as Augustine writes, 'we dwell in one another by the bond of love [per vinculis amoris $]^{2} .^{114}$ In De Catechizandis Rudibus, he recommends that the

\footnotetext{
${ }^{110}$ De Doct. Chr. III, xxxvii, 56.

111 Ibid. III. xxvii, 38.

112 Conf. XII, xxy, 35.

113 De Dial, ix.

${ }^{114}$ De Cat. Rud. xii, 17.
} 
best means of communicating our concepts is charity towards those to whom we are speaking. He writes:

So great is the power of a sympathetic disposition of mind that, as they are affected as we are speaking, and we are affected as they are learning, we have our dwelling in one another. Thus...they as it were in us speak what they hear, and we in them learn after a certain fashion what we teach. ${ }^{115}$

The principle of charity is the basis of all Augustine's rules for Scriptural interpretation. He writes that 'Scripture teaches nothing but charity', and that any expression that does not do this if taken literally must be figurative. ${ }^{116}$ Whatever Moses meant in the Pentateuch, 'he meant it to be understood in the spirit of [the] two precepts of charity', love of God and of neighbour, and so any interpretation of his words in accordance with this spirit is acceptable. ${ }^{117}$ Both reason and the rule of faith tell us that charity is God's will for us. ${ }^{118}$ It is the most effective means we have in our fallen state of effecting the presence of one mind to another, which is our aim when we use language. As a result, language is a means of charity. Augustine writes, 'Charity... would not have a means of infusing souls and almost mixing them together if men could teach nothing to men'. 119

Although we cannot use Augustine's Neoplatonic philosophical framework in a contemporary theory, there are nevertheless several aspects of his semiotics that could be worked into a Christian literary theory today. Firstly, we could follow his assertion that words are signs given to communicate a speaker's thoughts and feelings to another, and we could accept that the difference between mental life and language is so great that it is impossible to communicate

\footnotetext{
115 Ibid.

${ }^{116}$ De Doct. Chr. III. $\mathrm{x}, 15$.

117 Conf. XII. xxv, 35.

${ }^{118}$ De Doct. Chr. I. xxxv, 39; III, ii, 2.
} 
these thoughts and feelings perfectly in words. A Christian literary theory would therefore think of literary texts as imperfect communications of the author's experience. Secondly, we could follow St. Augustine in asserting that we may be unable to reduce the multiple meanings of a literary text, and that we will rarely be able to say with certainty what precisely an author meant. We need not accept his epistemological doctrines of reminiscence or of inner light, but we can understand his view that words make us look for things by asserting that literary texts give their readers ways in which to interpret their experience. Rather than believing that texts tell us what we already know, that is, we can say that they allow us to understand what we have experienced. Finally, Christian criticism could learn from Augustine the use of charity as a hermeneutic principle. Augustine applies the principle only to Scripture, but according to the logic of his concept of charity as the proper end of human action, we can follow him in using the principle in literary hermeneutics. Augustine defines charity as the twofold love of God and neighbour, and so we can take from him the principle that Christian criticism should prefer interpretations that pertain in some way to this love.

\section{St. Augustine's Theory of Beauty}

I will now turn to an examination of St. Augustine's theory of art, in order to establish which of its principles Christian literary theory can or should use today. To understand this theory, we must first examine Augustine's view of beauty, since he conceives the one in terms of the other. His most detailed discussions of

119 Ibid. proem., 6. 
beauty are to be found in the works written between the time of his conversion in 386 and his ordination in 391 . Between 386 and 387, he lived a life of study and prayer with friends and students at a friend's villa near Cassiciacum. In De Beata Vita (386), one of the philosophical dialogues composed during this period, Augustine argues that happiness, which all men desire, consists in wanting something that will make one happy, that is, something permanent, which cannot be removed by time or chance. God is absolutely permanent, and so 'he who possesses God is happy'. ${ }^{120}$ Augustine writes that 'He who arrives at the highest measure by means of truth is happy. He possesses God in his mind [animo Deum habere $]^{\prime}{ }^{121}$ Augustine discusses the nature of truth in De Libero Arbitrio (387396). He writes that knowledge comes from three faculties; the bodily senses, an 'interior sense', which perceives the acts of the bodily senses, and reason, which provides knowledge (scientia) properly so called. ${ }^{122}$ Reason is the highest faculty in man, by which he comes to know truth, and is surpassed only by truth itself. Truth, in Augustine's view, is unchangeable and eternal. If the whole world perished, it would still be true that it had perished. ${ }^{123}$ Augustine writes, "There is an unchangeable truth which contains everything that is unchangeably true', such as the rules of mathematics and of wisdom. ${ }^{124}$ It is like "some mysterious yet public light ${ }^{\prime}$ in which true propositions are intelligible to all. ${ }^{125}$ This eternal truth is that 'chief good' whose possession bestows happiness, namely God. ${ }^{126}$ This is the context of Augustine's aesthetics, that happiness consists in the certain knowledge of divine and eternal truth, to which reason alone can attain.

\footnotetext{
${ }^{120}$ De Beata Vita xi.

121 Ibid. xxxiv.

122 De Libero Arbitrio II, iv, 10.

${ }^{123}$ Ibid. II, vi, 14. Soliloquia I xV, 28.

${ }^{124}$ De Lib. Arb. II, xii, 33.

125 Ibid.
} 
Since beauty gives pleasure, the highest beauty is to be found in the highest pleasure, namely the mind's contemplation of eternal things in the light of truth. Augustine speaks of 'the beauty of truth and wisdom', which does not pass like that of a skyscape or of a song. ${ }^{127}$ In Contra Academicos (386), he speaks of 'the beauty of philosophy', and argues that the pursuit of beauty is an inferior type of the pursuit of wisdom, conducted at the level of sense-perception. ${ }^{128}$ Augustine writes:

What is philosophy? Love of wisdom. What is philocalia? Is it not love of beauty?... What, then, is wisdom? Is it not true beauty? ${ }^{129}$

Augustine writes that philosophy and philocalia are "sisters born of the same parent'. Philosophy can teach those who love the false beauties of sensible things to love her own 'true beauty', found in the contemplation of eternal truths. This had been Augustine's own experience, as he records in the Confessions (397): 'Your beauty [O God] drew me to you...I wondered how it was that I could appreciate beauty in material things'. ${ }^{130}$ Beauty is most properly an attribute of God, for St. Augustine. He writes:

It was you, O Lord, who made [material things], you who are beautiful, for they too are beautiful... But they are not beautiful... as you are beautiful...In comparison with you they have neither beauty nor goodness nor being at all. ${ }^{131}$

True beauty belongs to God. It is known by the mind, which contemplates Him in the eternal light of truth. Material things are beautiful insofar as they participate in the qualities of this intelligible beauty.

The most important of these qualities for Augustine is proportion. Proportion makes a thing beautiful because it manifests the principle of reason in it. In De

\footnotetext{
${ }^{126}$ Ibid. II, xv, 39.

${ }^{127}$ Ibid. II, xiv. 38.

${ }^{128}$ Contra Academicos II, ii, 7.

${ }^{129}$ Ibid.
} 
Ordine (386), St. Augustine writes that we call a visible object beautiful whose congruence of parts presents itself as rational (in cho congruentia partium rationabilis dicitur). We call a song or piece of music beautiful if its harmonies and rhythms appear rationally ordered to us. ${ }^{132}$ It is self-evident, according to Augustine, that the pleasure we derive from looking at or hearing a thing is produced by the ordered distribution of its parts. He calls this distribution dimensio atque modulatio, 'proportion and measure'. ${ }^{133}$ In De Vera Religione (390), Augustine writes that a symmetrically constructed building gives pleasure because it is beautiful, and that it is beautiful because 'its parts correspond and are so joined together as to form one harmonious whole [unam convenientiam]'. ${ }^{134}$ The beauty of the natural universe derives from the same quality. Augustine writes, "The world is full of designs and is beautiful... because of the reason that is in it [ratione]'. ${ }^{135}$ All greater things are made out of lesser parts, each proportionally related to the other and all related to the whole. This is true also of the cycles of time. In De Musica (388-391), Augustine writes:

The circling sky continually returns to its place of starting, recalling thither the heavenly bodies, with the days, months, years, five-year periods and other cycles of time... according to the laws of equality, unity and order. ${ }^{136}$

The order of the temporal universe is its beauty. Augustine writes, 'The whole rhythmic succession and gradation in space and time is judged to be beautiful... by its ordered fitness [ordinata convenientia] ${ }^{137}$

${ }^{130}$ Confessiones VII, xvii, 23.

131 Ibid. XI, iv, 6.

${ }^{132}$ De Ordine II. xi, 33.

133 Ibid.

${ }^{134}$ De Vera Religione xxxii, 59.

135 Ibid. xliii. 80.

${ }^{136}$ De Musica VI, x, 29.

${ }^{137}$ De Vera Religione xliii, 80. 
The value of sensible beauty, for Augustine, is that by prompting us to consider the intelligible principles in which it consists, it can lead us to the contemplation of those principles in which happiness is to be found. He writes:

Nothing hinders the perception of truth more than a life devoted to...the false images of sensible things... The mind has to be healed in order that it may behold the immutable form of things which remains ever the same. ${ }^{138}$

God in his mercy has provided for this healing by the temporal dispensation, in which "he has used the mutable creation, obedient however to his eternal laws, to remind the soul of its original and perfect nature'. ${ }^{139}$ Beauty is a part of this providential dispensation. As Robert J. O'Connell writes in Art and the Christian Intelligence in St. Augustine (1978), this is 'an aesthetic for the fallen soul'. ${ }^{1+0}$ Augustine's criterion of proportion demands unity and equality in an object, the equality or similarity of parts and intervals to one another, and the harmonious unity of the whole so comprised. But, Augustine writes, 'Who can find absolute equality or similarity in bodily objects? Who would venture to say...that any body is truly and simply one?" ${ }^{141}$ In the case of unity, it is clear that 'it cannot be perceived by the senses' ${ }^{142}$ Any bodily object has innumerable parts. However compact, it has a top and a bottom, a left-hand and a right-hand side, and so on. These parts could not be counted without some notion of unity, because all numbers are multiples of one, so unity must be known with the mind rather than with the senses. Augustine writes, 'We must know this by the inner light, of which bodily sense knows nothing'. ${ }^{143}$ Now sensible things clearly possess a trace (vestigium) of the intelligible unity, and the more beautiful they are the

\footnotetext{
138 Ibid. iii, 3.

${ }^{139}$ Ibid. $\mathrm{x}, 19$.

${ }^{140}$ Robert O'Connell. Art and the Christian Intelligence in St. Augustine (Oxford: Blackwell, 1978) p. 25.

${ }_{141}$ De Vera Religione $\mathrm{xxx}, 55$.
} 
more marked is this trace. ${ }^{144}$ Sensibly beautiful things 'imitate but cannot completely achieve [non posse assequi eam quam sequitur]' unity, and by doing so they prompt us to seek the true unity of which they are imperfect copies. ${ }^{145}$ When we seek true unity, we find it in the realm of intelligible truths illuminated by the divine light of truth. Augustine writes 'By the true light you see the unity whereby you judge whatever you see to be one'. ${ }^{146}$ It is the same with the equality of sensible beauties. We judge sensibly equal things by the 'absolute standard of equality' which exists in the beatific order of eternal truth. ${ }^{147}$ For Augustine sensible beauty is a 'pointer towards the happy life [admonitio beatae vitae $]^{\prime}$ in a realm where happiness is not otherwise to be found. ${ }^{148}$ It is one of the 'steps made by divine providence [gradibus quos...divina providentia fabricare]' by which our fall into our present state, in which sense usurps the proper domination of reason in our souls, can be undone. ${ }^{149}$

There is less in Augustine's aesthetics that we can use in Christian literary theory today than in his semiotics, since it is so deeply permeated by his Neoplatonic metaphysics. Nevertheless, there are several principles which we can accept. We can follow Augustine in asserting that beauty is primarily an attribute of God. We can accept that God is the most beautiful of beings, whose transcendent beauty is obscurely known from the beauty of created things. We cannot accept the rationalism of Augustine's aesthetics, but we can use some of its other-worldly emphasis. We can say, that is, that sensibly beautiful things can lead us to consider the more perfect beauty of God, but we need not assert with

\footnotetext{
${ }^{142}$ De Libero Arbitrio II, viii, 22.

143 Ibid. II, viii, 24.

${ }^{144}$ De Vera Religione xxxii, 60.

145 Ibid.

146 Ibid. xxxiv, 64.

${ }^{147}$ Ibid. $\mathrm{xxx}, 56$.
} 
Augustine that they do so by means of the intelligible principles according to which they are constructed. We can take from Augustine the principle that the beauty of a literary work is a pointer to the perfectly satisfying beauty of God, known in the beatific vision. We can follow him in defining beauty in such works as that which puts the reader in mind of a happier, more blessed life than his or her own.

\section{St. Augustine's Theory of Art}

St. Augustine distinguishes between art 'in the vulgar sense' (ars vulgaris) and the liberal arts. The former comprises 'nothing but the memory of things we have experienced and which have given us pleasure, with the addition of some skilled bodily activity,. ${ }^{150}$ This combination of memory and physical skill comprises such arts as building, playing musical instruments and singing. They are 'not far from reason and truth', but they are to be distinguished from science, or the liberal arts, which pertain to reason alone. ${ }^{151}$ Vulgar arts pertain both to the senses and to reason. Nevertheless, they have their place in the dispensation of providence. Augustine writes:

The artificers of all corporeal forms work by number and regulate their operations thereby [habent numeros quibus coaptant opera sua]... They move their hands and tools until that which is fashioned in the outer world, being referred to the inward light of number, receives such perfection as is possible. ${ }^{152}$

Numbers are truths unavailable to the senses, which we know by the divine inner light of truth. Both the number one, of which all others are multiples, and the

\footnotetext{
148 Ibid. xlv, 84.

149 Ibid. I, 98.

${ }^{150}$ Ibid. $x \times x .54$.

${ }^{151}$ Ibid. De Musica I, iv, 6.
} 
'fixed and unchangeable law' of the numerical series, are eternal truths. ${ }^{153}$ Number is the basis of order and hence of the proportion which causes beauty. Augustine writes, 'Examine the beauty of bodily form, and you will find that everything is in its place by number'. ${ }^{154}$ The skill of an artist, like the beauty of his work, derives from number, as the artist learns the proper order of movements necessary to make or perform the work. An art-work makes us think of the skill by which it was made, and those who know how to behold it rightly will 'rise above even the mind of the artificer to behold the eternal realm of number'. ${ }^{155}$ As Augustine writes in the Confessions, 'The beauty which flows through men's minds into their skilful hands comes from that beauty which is above their souls". ${ }^{156}$

The liberal arts (artes liberales) or school disciplines (disciplinae) lead the soul more surely to the eternal realm, since they are of an entirely intellectual nature. They are the study of the rational principles which govern a given field of practice. In the Soliloquies, Augustine writes that a discipline consists in 'definitions, divisions and reasonings, where the nature of each thing is set forth [and] each part receives its due attention without confusion' ${ }^{157}$ Since these rules are learnt and hence known, and since one cannot know what is false, Augustine writes that all the disciplines are true. ${ }^{158}$ In De Immortalia Animae (387), he writes that the truths they teach are eternal and present in the soul. ${ }^{159}$ In $D e$ Ordine (386), he lists the liberal arts as grammar, rhetoric, dialectic, music, geometry and astronomy. Each comprises a system of rules discerned by reason,

\footnotetext{
${ }^{152}$ De Libero Arbitrio II, xvi, 42.

${ }^{153}$ Ibid. II, viii. 23.

154 Ibid. II, xvi. 42.

155 Ibid. II, xvi. 43; 42.

${ }^{156}$ Confessiones $\mathrm{X}$, xxxiv, 53.

157 Soliloquia II. xi, 21.
} 
and which pertain to number. ${ }^{160}$ Augustine writes, "In all the disciplines, everything presented itself to [reason] as governed by numbers [numerosa], ${ }^{161}$ Since number is of the order of eternal truth, careful study of the liberal arts can lead the mind to beatific contemplation of this truth. ${ }^{\text {ió }}$ This means that knowledge of the numerical rules by which an art-work is made is more valuable than the work itself. Augustine writes, 'The art of versifying is not subject to change with time' as verses themselves are, since it possesses eternally the rules for making temporal verses. Verse itself is beautiful by 'exhibiting faint traces of the beauty which the art of poetry keeps steadfastly and unchangeably'. ${ }^{163}$ Those 'perverse people' who prefer poems to the art of poetry prefer temporal things rather than God, who created time and providentially governs it. ${ }^{164}$ This, according to Augustine, is as absurd as wanting continually to hear one syllable during the recitation of a whole poem.

St. Augustine discusses the art of verse in detail in De Mussica. This work is concerned primarily with poetic rhythm. Augustine defines music as the "science of measuring well [scientia bene modulandi]'. As H.-I. Marrou points out in Saint Augustin et la Fin de la Culture Antique (1938), this science pertained in late antiquity both to rhythmic and harmonic measures. ${ }^{165}$ St. Augustine confines his discussion to rhythm and hence to verse, with which his profession as a teacher of rhetoric had made him familiar, rather than to music in our sense of melody and harmony. Music, for Augustine, is a science, that is, a 'pure and true

\footnotetext{
${ }^{158}$ Ibid. II, xi, 20.

${ }^{159}$ De Immortalia Animae iv, 5.

${ }^{160}$ De Ordine II, xii, 35-xv, 43.

161 Ibid. II, xv, 43.

${ }_{162}$ Ibid. II, xvi, 44.

${ }^{163}$ De Vera Religione xxii, 42.

${ }^{164}$ Ibid. xxii. 43.

${ }^{165}$ Henri-Irénée Marrou, Saint Augustin et la Fin de la Culture Antique (Paris: Boccard. 1949) p. 267.
} 
understanding' of the numerical relations by which poetic rhythms are constructed. ${ }^{166}$ Neither songbirds nor those who play instruments by ear possess such understanding. They can 'produce numerical works' (mumerosa facere) but they do not 'know numbers' (numeros cognoscere), by which the works are produced. ${ }^{167}$ The value of the science of music is that it can lead those minds which incline towards grammar and poetry 'from the things of sense to God, with reason as a guide'. ${ }^{168}$ Augustine writes, 'I have written for those who possess secular education, but... do not know where the true joy is' ${ }^{169}$

The pleasure we take in rhythmic verse derives from the principle of equality which underlies its measures. Augustine writes, 'What possible principle can bring all feet into mutual harmony except the principle of equality? ${ }^{3170}$ We know that true equality is an eternal principle, towards which imperfect sensible equalities point us. The rhythms which govern the whole temporal universe guide our reason to this true equality. Augustine writes:

The higher things are those in which equality resides supreme, unshaken, unchangeable, eternal; where there is no time, because no mutability; whence, in imitation of eternity, times in our world are made, ordered and modified. ${ }^{171}$

The rhythms of the temporal universe make it comprehensible as a great metrical poem, a carmen universitatis or 'universal song'. The beauty of poetic rhythm, Augustine writes, is 'formed out of our penal mortality', that is, out of the passing and sensible things which we chose at the fall over the eternal knowledge of God for which we were made. ${ }^{172}$ Nevertheless, as we know, God 'has not so forsaken us that we cannot be recalled from carnal delight and

\footnotetext{
${ }^{166}$ De Musica I, iv, 8.

167 De Ordine II, xix, 49.

${ }_{168}^{68}$ De Musica VI, i, 1.

${ }^{169}$ Ibid.

${ }^{170}$ Ibid. VI, x. 27.
} 
quickly retrace our way' to Him. ${ }^{173}$ In the 'rhythm which passes' we can recognise 'the rhythm which remains', by which the former is constructed. ${ }^{174}$ Temporal verse is a gift of divine providence, 'in its own kind beautiful'. We must not love it in itself, because it cannot make us happy in itself, but rather treat it 'as a plank amid the waves of the sea', neither rejecting it as a burden nor clinging to it as if stable. ${ }^{175}$ Augustine writes, "We must use it well, so that eventually we may dispense with it? ${ }^{276}$

St. Augustine says less about the content of poetry than its rhythm. In De Ordine, he writes that poets apply the principle of number not only to the sound of their words but also to the relations between words and to the things which those words signify. ${ }^{177}$ Hence poetry can be called the "power of inventing rational fictions [rationabilium mendacionum potestatem]' ${ }^{178} \mathrm{He}$ gives as an example of such a fiction the myth that the Muses are the daughters of Jove and Memory. The 'reason' in this myth is the truth it signifies, namely that music derives both from the divine principle of number and from the human memory In the first book of the Confessions, Augustine is more austere. He describes the epic poems he learned in his youth as 'empty'. He writes:

I was obliged to memorise the wanderings of a hero named Aeneas, while in the meantime I failed to remember my own erratic ways. I learned to lament the death of Dido... while all the time...I was dying, separated from you, my God. ${ }^{179}$

\footnotetext{
${ }^{171}$ Ibid. VI, x, 29.

${ }^{172}$ Ibid. VI, xi, 33. Cp. De Genesi contra Manichaeos II, xi, 15-xx, 30.

${ }^{173}$ De Musica VI, xi, 33.

174 Ibid, VI, xii, 35.

175 Ibid. VI, xiv, 46

176 Ibid

${ }^{177}$ De Ordine II, xiv, 40.

178 Ibid.

${ }^{179}$ Confessiones I, xiii, 20.
} 
Augustine's theme in the first book of the Confessions is that he 'looked for pleasure, beauty and truth not in [God] but in myself and his other creatures'. ${ }^{180}$ He is concerned with having used poetry wrongly, that is, having loved it in itself. Nevertheless, it is in keeping with his aesthetics that the fiction of Aeneas' wanderings, if used rightly, could be valuable by reminding the soul of its own wanderings. This is the logic of the concept of rational fiction. The pleasure the soul takes in such fiction could be seen to derive from the principle of number which underlies the arrangement of its parts. In fact, Augustine's concern with poetry in the Confessions is not essentially different from that of the De Musica. Both works are concerned with the right use of a temporal good; the latter simply places greater emphasis on the danger of its misuse. In De Trinitate, Augustine describes the twofold good of poetry as musical rhythm and 'profound thought' ${ }^{181}$ Even in his later works, he regards the content of poetry as valuable. This is shown by his repeated use of citation from the Latin poets to illustrate points in an argument. As he discusses the production of the verbum cordis in conscious knowledge, Augustine writes:

That great master of language, Vergil, knew well the value of words, with a sure insight into the nature of thought, when he wrote in his poem, 'He passes within himself the varied happenings of war'. ${ }^{182}$

It is possible for poetry to express 'sure insight' into truth. Despite the austere presentation in the first book of the Confessions, in practice Augustine did not abandon his early concept of the rational fiction. He uses poetry to illustrate his arguments throughout $\mathrm{De}$ Civitate $\mathrm{Dei}$ (413-426). To give one example from

\footnotetext{
${ }^{180}$ Ibid. I, xviii, 31.

${ }^{181}$ De Trin. VIII, iii, 4.

${ }^{182}$ Ibid. XV, xvi, 25.
} 
many, he describes the 'perception' expressed in Horace's poetry as 'morally clear-sighted' ${ }^{183}$

It is difficult to make use of Augustine's Pythagorean aesthetics of number today, but there are several principles that a Christian literary theory can take from his theory of art nevertheless. We can no longer accept his belief that number is the principle of the beauty of literary works, but we could translate this aspect of his aesthetics into the more general principle that literary works manifest something beyond themselves, and that this is the nature of their beauty. We could also take his concept of rational fiction to mean that fictional texts can teach their readers truths about their own experience, and that these truths can be ethical, that is, that they can challenge a reader to change his or her actions.

(iii) St. Thomas Aquinas

As F.C. Copleston writes, St. Thomas Aquinas (1225-1274) occupies a 'favoured position in the intellectual life of the Catholic Church' ${ }^{184} \mathrm{He}$ was canonised in 1323, and declared a doctor of the church in 1567. According to Josef Pieper, in his Guide to Thomas Aquinas (1962), St. Thomas was the first to be canonised primarily for having been a teacher. ${ }^{185}$ In 1917, the Code of Canon Law required teachers in Catholic seminaries to hold and teach his method,

\footnotetext{
${ }^{183}$ De Civ. Dei V, xiii.

${ }^{184}$ F.C. Copleston, Aquinas (London: Penguin, 1955) p. 235.

185 Josef Pieper, Guide to Thomas Aquinas, tr. Richard and Clara Winston (Notre Dame:

University of Notre Dame Press, 1962) p. 17.
} 
doctrines and principles. ${ }^{186}$ In his encyclical Studiorum Ducem (1923), Pope Pius XI declared that 'the Church has adopted his philosophy for her very own' ${ }^{187}$ The century before St. Thomas wrote had seen the translation into Latin of many of Aristotle's works besides the familiar Logic, and of the works of Islamic and Jewish philosophers influenced by their knowledge of Aristotle in Arabic translations. ${ }^{188}$ Like his teacher Albert the Great (1206-1280), St. Thomas believed that much of this Aristotelian philosophy was true, and that it therefore 'provided a powerful instrument in the construction of a general Christian worldview, ${ }^{189}$ He used Neoplatonic ideas from Augustine and Pseudo-Dionysius, but, where he believed their philosophy was lacking, reinterpreted and replaced it. As Étienne Gilson writes of St. Thomas' method, in Christian Philosophy in the Middle Ages (1955), 'When a theologian has good reason to think that Augustine did not make use of the best possible philosophy, he should not hesitate to change it". ${ }^{190}$

\section{Theological Language}

As Robert $\mathrm{H}$. Ayers writes, in Language, Logic and Reason in the Church Fathers (1979), the context of St. Thomas' theories of language is his 'pursuit of

\footnotetext{
${ }^{186}$ Codex Iuris Canonici (Vatican City: Typis Polyglottis Vaticanis, 1931) no. 1366. The revised code of Canon Law issued under John Paul II in 1983 is less exclusive, stipulating only that St. Thomas is to be 'the teacher in a special way [praesertim]' of students of dogmatic theology. Code of Canon Law: Latin-English Edition (Washington, DC: Canon Law Society of America, 1983) no. 252.

${ }_{187}^{183}$ Pius XI, 'Studiorum Ducem', Acta Apostolicae Sedis 15 (1923) p. 314.

${ }^{188}$ See F.C. Copieston, A History of Medieval Philosophy (London: Methuen, 1972) pp. 104-159.

${ }^{189}$ lbid. p. 180. See Josep h Owens, 'Aristotle and Aquinas', in Norman Kretzmann and Eleonore Stump, eds. The Cambridge Companion to Aquinas (Cambridge: Cambridge University Press, 1993) pp. 38-59.

199 Étienne Gilson. Christian Philosophy in the Middle Ages (London: Sheed and Ward, 1955) p. 364.
} 
the clearest and most complete understanding possible of the Christian faith'. ${ }^{191}$ He thought of language with a view to the clearest possible understanding of theology. In his commentary on Aristotle's De Interpretatione (1269-1272), St. Thomas writes that language arises as a result of man's social nature. If he were solitary by nature, his knowledge of things would suffice for him. But since he is a social and political animal, 'it was necessary that his conceptions [conceptiones] be made known to others' ${ }^{192}$ Since he does this through utterance (per vocem), Thomas writes, 'there had to be significant utterances [voces significativas] in order that men could live together'. ${ }^{193}$ Aristotle wrote, 'Spoken sounds are symbols [sumbola] of affections of the soul, and written marks are symbols of spoken sounds'. ${ }^{194}$ Thomas understands Aristotle's passiones animae to mean intellectus conceptiones, 'conceptions of the intellect', and asserts that these are likenesses (similitudines) of the things known. ${ }^{195}$ Spoken words, however, are signs (notae, idest signa) of these forms not because of any likeness to them but because of human institution (ratio institutionis), or convention (placitum). ${ }^{196}$ As a result of the conventional nature of the meaning of words, Thomas writes that care should be taken to 'use words as most people use them' in order that our conceptions are not misunderstood. ${ }^{197}$ As Aristotle said, 'The usage of the multitude... is to be followed in giving names to things' 198

\footnotetext{
${ }^{191}$ Robert H. Ayers, Language, Logic and Reason in the Church Fathers: A Study of Tertullian, Augustine and Aquinas (Hildesheim and New York: Georg Olms Verlag, 1979) p. 82.

192 In Libros Perihermenias I, ii, 2. This work will henceforth be abbreviated as In Perih.

${ }^{193}$ Ibid.

${ }_{195}$ Aristotle. De Interpretatione $116 \mathrm{a}$.

195 Ibid. I, ii, 5.

${ }^{196}$ In Perih. I. ii, 9; I, iv, 11.

${ }^{197}$ De Veritate IV, ii.

${ }^{198}$ Summa Contra Gentiles I, i, 1.
} 
In De Veritate (1256-1259), Thomas writes that a name is derived from two sources, 'from the one who uses the word [ex parte imponentis] or from the thing to which it has been applied [ex parte rei cui imponitur]'. ${ }^{199}$ In his commentary on the Sentences of Peter Lombard (1252-1256), Thomas calls the former the quality of the name and the latter its substance. ${ }^{200}$ The latter is what he also calls the 'definition' of a name. It is in this sense that he writes in the Summa Theologiae (1265-1273) that the meaning of a name is its definition (ratio... quam significat nomen est definitio). ${ }^{201}$ In De Ente et Essentia (12521256), he explains the concept of definition by writing, "What sorts things into their proper genus and species are the definitions [diffinitionem] that express what they are'. ${ }^{202}$ He writes, 'Essence is what is expressed in a definition'. ${ }^{203} \mathrm{~A}$ definition expresses a thing's essence by demarcating it according to genus and species, by virtue of which it is intelligible. It is 'the thing's specific difference and... what a word properly signifies'. ${ }^{204}$ Since the intellect, which knows essences, is presented with images of sensible objects by the senses, which know only the external accidents of a thing, Thomas writes that 'we use accidents or effects in their [i.e. essences ${ }^{2}$ ] place and name a thing accordingly'. ${ }^{205}$ This is the first of the two sources of names that St. Thomas distinguishes, that from the one who uses the word. In this kind of name, the sensible properties or operations of a thing are used to signify the thing itself. Thomas writes, 'Because we name a thing in accordance with our knowledge of it...so from external properties

\footnotetext{
${ }^{199}$ De Ver. IV, i ad 8.

${ }^{200}$ In III Sententiarum d.6 q. 1 a.3.

201 Summa Theologiae Ia 13, 1. This work will henceforth be abbreviated to ST.

${ }^{202}$ De Ente et Essentia 1.

${ }^{203}$ Ibid. 6.

${ }^{204}$ De Ver. IV. 1 ad 8.

205 Ibid.
} 
names are often imposed to signify essences'. ${ }^{206}$ In this case the word is used 'less properly' (minus proprie). Hence when Thomas writes that 'the meaning of a word is our intellectual conception of the thing signified by it', the conception to which he refers is properly that of the thing's essence, and less properly the sensation of its accidents and operations, from which the concept is abstracted. ${ }^{207}$

When St. Thomas discusses language about God, he establishes first what one can know of God. This is the subject of question Ia 12 of the Summa Theologiae. Thomas writes that a thing is knowable so far as it is actualised (in actu). God is wholly actualised, there being nothing in him that is merely potential, and so in himself is the most knowable of beings (in se est maxime cognoscibile). ${ }^{208}$ The blessed, as a result, are able to see the essence of God, although not to 'comprehend' or perfectly understand it. ${ }^{209}$ In this life, however, a person cannot even see the essence of God. This is because the mode of knowledge depends on the mode of being of the knower. Since our souls in this life have their being in matter, they can by nature only know those things which also have their form in matter, or what can be known through such things. ${ }^{210}$ God's essence cannot be so known. We can know of Him that he exists, and that 'he is all that belongs to the first cause of all things which is beyond all caused things' ${ }^{211}$ As a result, we cannot use words of God with the meanings ordinarily proper to them. Nevertheless, since we can deduce a certain amount about Him from creatures,

\footnotetext{
${ }^{206}$ ST Ta 18, 2.

207 Ibid. Ia 13. 4. See Ralph M. McInerny, Aquinas and Analogy (Washington DC: Catholic University of America Press, 1996) pp. 53-85.

${ }^{208}$ Ibid. Ia 12, 1.

${ }^{209}$ Ibid. Ia, 12, 7

210 Tbid. Ia, 12, 11.

211 Ibid. Ia, 12, 12.
} 
whose essences we do know, we can use words whose meanings properly refer to creatures to speak of Him. ${ }^{212}$

We know God from creatures according to the way they represent Him (secundum quod creaturae ipsum repraesentant), which they do insofar as they possess any perfection (perfectionem aliquam). ${ }^{213}$ St. Thomas' writes that 'a thing is perfect in proportion to its state of actuality'. ${ }^{214}$ Insofar as a thing is fully the thing it ought to be, with none of its appropriate qualities remaining merely potential, it is perfect. Thomas writes, 'Things are perfect insofar as they have their being after some fashion'. ${ }^{215}$ God actualises being in every way, and hence contains within His simplicity the perfections of all creatures who actualise their being only in the way appropriate to them. Furthermore, Thomas believes that if a perfection exists in an effect, it must also exist in its efficient cause. He writes, 'The effect pre-exists virtually in the efficient cause'. This is to exist 'in a more perfect way', 216 For Thomas, "every agent reproduces itself insofar as it is an agent and everything acts according to the manner of its form', which means that the effect must in some way resemble the form of the agent. ${ }^{217}$ Creatures resemble God, who is their first efficient cause, as their 'superior source, whose form the form of the effect fails to reproduce, although it resembles it in some way'. ${ }^{218}$ Hence words like 'good' and 'wise' can be predicated of God's substance, but they refer to it imperfectly (significant imperfecte), since that is the way in which creatures represent it. ${ }^{219}$ In terms of the things signified (res significata) in this way, these words are used more properly (magis proprie) of

\footnotetext{
${ }^{212}$ Ibid. Ia $13,1$.

${ }^{213}$ Ibid. Ia 13, 2.

214 Ibid. Ia $4,1$.

${ }^{2 i}{ }^{2}$ Ibid. Ia 4, 2.

216 Ibid.

${ }^{217}$ Ibid. Ia 4, 3.
} 
God than of creatures, since the perfections they denote belong primarily to God, and only derivatively to creatures. But according to the mode of signifying (modus significandi), such words are used more properly of creatures, from which they are derived. ${ }^{220}$ Thomas calls this dual relation of words to God and to creatures analogy. He writes, "Words are said of God and of creatures by analogy, that is, according to proportion [secundum analogiam, idest proportionem]' ${ }^{221}$ Thomas distinguishes two kinds of analogy, that in which two senses of a word are related to one common concept (multa habent proportionem ad unum), and that in which a word is used in two senses because of a relation between these senses (umum habet proportionem ad alterum) ${ }^{222}$ Words are said analogically of God and creatures in the second sense, that is according to the order of the creature towards God [ordo creaturce ad Deum] as origin and cause, in whom all the perfections of things pre-exist in a superior way [excellenter] ${ }^{223}$

St. Thomas' theories of language give us several ways in which to think of the language of literary works. We can take from him the principle that the end of language is communication, and that words are signs of mental experience, given because man is a naturally social animal, who desires to share his experience. Christian literary theory could therefore see a literary text as a system of signs of the author's mind, given in order to communicate concepts he or she has formed. We can no longer accept Thomas' Aristotelian view that the meaning of a noun is the definition of the essence of the thing conceived by genus and species. We do not need to assert that there is a real order of things in nature to believe that it

\footnotetext{
${ }^{218}$ Ibid. Ia 13. 2.

${ }^{219}$ Ibid.

${ }^{220}$ Ibid. Ia, 13, 3.

${ }^{221}$ Ibid. Ia, 13, 5 .

${ }^{222}$ Ibid. Cp. Summa Contra Gentiles I, 34.

${ }^{223} S T \mathrm{Ia}, 13,5$.
} 
is God's creation. We can follow St. Thomas in asserting that we name things as we conceive them, however. Christian literary theory can understand the signs given in a literary work as signs of the author's concepts of the things he or she is trying to communicate. Finally, as I suggested in Chapter 1, we can use St. Thomas' doctrine of analogy as a rationale for the use of theological language that Christian criticism will necessarily entail. We can take from St. Thomas the principle that our language about God signifies our concepts of Him, formed from creatures which represent Him imperfectly, as effects resemble their cause. This means that we know almost nothing of God. The theological language we use in Christian criticism signifies only what little we know, namely that what we know of creatures exists more fully than we can understand in God.

\section{St. Thomas' Theory of Beauty}

St. Thomas' longest discussion of beauty is found in the fourth book of his commentary on the Divine Names of Pseudo-Dionysius (1265-1266). He begins by distinguishing between that which is beautiful (pulchrum) and beauty (pulchritudo). Whilst the beautiful is a participant in beauty,

Beauty is a participation in the first cause, which makes all things beautiful. For the beauty of creatures is nothing other than the likeness of the divine beauty in which things participate. ${ }^{224}$

Thomas analyses the ways in which the terms 'beautiful' and 'beauty' can be predicated of God. Dionysius calls God supersubstantiale pulchrum, beautiful beyond being. Thomas interprets this to mean that one can speak of his beauty because 'he gives beauty to all created beings, according to the specificity of

${ }^{224}$ In Dionvsii de Divinis Nominibus IV, 5. Until otherwise indicated, the following citations are from this lectio. The work will henceforth be abbreviated to In Div. Nom. 
each'. One can speak of God as beautiful 'by way of excess' (secundum excessum) and 'by way of cause' (per causam). There are two kinds of excess, according to Thomas: that within and that outside of a genus. Fire exceeds in heat by an excess in the genus of heat, but the sun exceeds in heat by an excess outside the genus. As a result, fire is called calidissimus, 'most hot', and the sun supercalidus, 'beyond heat'. Whilst these two kinds of excess do not coincide in any creature, God can be called both most beautiful (pulcherrimus) and beyond beauty (superpulcher). The former refers to his lack of any defect in beauty which occurs in creatures as a result of their variability and of their particularity. God is beyond beauty insofar as 'he has in himself, exceedingly and before all else, the fount of all beauty'. All beauty and all beautiful things pre-exist uniformly in God's simple nature, 'in the way in which many effects pre-exist in a cause'.

Although he does not say so explicitly, St. Thomas seems to regard beauty as a transcendental, that is, as a general property of being. In De Veritate (12561259), he describes such properties as follows:

Our first mental conception... is what exists [ens]. Consequently, every other mental conception adds something to what exists... This means expressing some way in which what exists exists not expressed in the word existing... The way expressed can be a general way attaching to everything that exists. ${ }^{225}$

Scholastic tradition describes the concepts that add to being in this general way as transcendentals. They are properties that belong to every being. They differ from being and from each other conceptually but not in reality. They are different ways in which being can be conceived. In De Veritate, Thomas lists five of these concepts, res, unum, aliquid, bonum and verum, that is, being a thing, one, something, good and true. In the Commentary on the Divine Names, 
he identifies the beautiful with the good, asserting that they are same in the subject [idem in subiecto] but differ conceptually [ratione]. He expands upon this definition in the Summa Theologiae (1265-73):

The beautiful and the good are the same in a subject... But they differ conceptually [ratione]. The good relates to the appetite, for it is the good that all things desire... But the beautiful relates to the cognitive power [respicit vim cognoscitivam]; for those things are called beautiful which please when seen. ${ }^{226}$

For St. Thomas, the beautiful is the good perceived with the cognitive faculties of the senses and the intellect, rather than desired with the appetite. As Armand Maurer writes in About Beauty: A Thomistic Interpretation (1983), 'The beautiful attracts us to look at it, but not to possess it [as the good does] ${ }^{227}$ It seems reasonable to assert that if, for St. Thomas, the good is a transcendental, differing from being only conceptually, and if the beautiful is the same as the good, differing only conceptually, then the beautiful is also a transcendental.

This means that all that is, is beautiful. It does not mean that all beings are equally beautiful, however. Aquinas writes that, in contrast to God's perfect beauty, "there are two sorts of defect of beauty [defectus pulchritudinis] in creatures' ${ }^{228}$ Their beauty is variable (variabilem) as a result of their temporal and corruptible natures, and it is particularised (particulatam) as a result of their individual natures. ${ }^{229}$ This means that they can be beautiful at one time but not at another, and be beautiful in one part but not in another. Creatures are determined towards a particular end, which means that they can be beautiful in relation to some things but not in relation to others. This in turn means that they can seem beautiful to some people and not to others.

\footnotetext{
225 De Veritate I. 1.

${ }^{226}$ ST la 5, 4 ad 3. See also ibid. Ia-IIae 27, 1 ad 3.

${ }^{227}$ Armand Maurer, About Beauty: A Thomistic Interpretation (Houston: Centre for Thomistic Studies, 1983) p. 18.

${ }^{228}$ In Div. Nom. IV, 5.
} 
In a well-known passage of the Summa Theologiae, St. Thomas gives his fullest definition of beauty $\mathrm{He}$ argues that comeliness or beauty (species sive pulchritudo) is a predicate appropriate to the Second Person of the Trinity. He writes:

Three things are required for beauty. First, integrity or completeness [integritas sive perfectio], for those things that lack something are thereby ugly; second, due proportion or harmony [debita proportio sive consonantia]; and finally brightness [claritas], since we call things beautiful that have a shining colour [colorem nitidum]. ${ }^{230}$

St. Thomas repeatedly describes the beautiful in terms of clarity and proportion.

It is only in this passage that he also uses the terms integrity or perfection. St.

Thomas defines the twofold sense of perfection in things as follows:

The first type of perfection is that according to which a thing is perfect in its substance. This is form of the whole, which arises from the integrity [integritate] of its parts. The second type of perfection is the end. This is either an operation... or something attained to by an operation. ${ }^{231}$

The first type of perfection is the adequacy of a thing with respect to the kind of thing it is. Thomas writes that things that lack something are thereby ugly. A beautiful thing has nothing missing that is proper to it. When a thing is fully the kind of thing it ought to be, then it has the beautiful quality of integrity. To understand the second type of perfection, we need to emphasise one of the senses of the term 'form' in St. Thomas. Form, as we will discuss in more detail below, is that by which a thing is the kind of thing it is. This determines a thing's end, and hence its proper operation with respect to that end. Thomas writes, 'Upon the form follows an inclination to the end... for everything, insofar as it is in act, acts and tends towards that which is in accordance with its form? ${ }^{232} \mathrm{~A}$ thing is perfect in this sense when it does all that it ought to do, when it fully performs

\footnotetext{
${ }^{229}$ Ibid.

${ }^{230}$ ST la 39.8

${ }^{231}$ Ibid. Ia 73, 1.
} 
the function proper to it. Insofar as it does so, it has the beautiful quality of integrity. As Thomas says, the second perfection follows from the first: when a thing is all it should be, it also does all it should do. When he speaks of 'due' proportion as a quality of the beautiful, it is these formal perfections to which he refers.

Thomas' second criterion for the beautiful is proportion or consonance. Albert the Great had defined proportion and clarity as standards of the beautiful in his commentary on the Divine Names, De Pulchro et Bono (1248-1249), which Thomas had transcribed. In an article of the Summa that raises the question of the proportion of the mind to the object of its knowledge, St. Thomas defines the two senses of proportion as follows:

One sense indicates a certain relation of one quantity to another, according to which double, triple and equal are kinds of proportion. The other sense indicates any kind of relationship [quaelibet habitudo] of one thing to another. ${ }^{233}$

The beautiful quality of due proportion or harmony denotes proper relations in and among things. For St. Thomas, the universe comprises a vast series of such relations. He writes that God gives beauty to all created beings 'insofar as he is the cause of harmony (consonantia)...in all things'. There are two kinds of harmony in things, Thomas writes. Firstly, that according to which all things are ordered towards God. God causes this harmony by ordaining all things towards Him as their end or goal. Secondly, there is the harmony according to which all things are ordered towards each other. Greater things can be said to be in lesser things 'by way of participation' (secundum participationem), and lesser things in greater 'by a certain excellence' (per excellentiam quamdam). In this way all things are related to each other, and all are mutually ordered towards the one 
end. Thomas describes an array of ways in which all things in the universe are related to one another. Things are beautiful by remaining themselves, yet they also exist in other things, and this relationship of all things to one another (communio omnium in omnibus) is one of consonance. Thomas writes, "All things lead back to the causality of the beautiful, because they pertain to consonance'. ${ }^{234}$ Just as many stones fit together (convenientur) to make a house, so in the nature of existence all the parts of the universe fit together. They are all suited (coaptantur) to this mutual relationship, and each part is supported (invetur) by the others, since they are all distributed in proper proportion to one another. Thomas writes, 'All the parts of the universe constitute one single universality of things'. ${ }^{235}$

Beauty is an analogous quality, for St. Thomas, which is to say that it has different senses in different contexts. He writes, "Spiritual beauty is different to corporeal beauty, and the beauty of one body is different to that of another' ${ }^{236}$ This applies to proportion: there is a corporeal and a spiritual proportion, and the proportion of one body is not that of another. The former consists in a proper distribution of parts with respect to the whole of a body. Thomas' most frequent example is that of the human body, whose beauty consists in 'properly proportioned members' (membra...bene proportionata). ${ }^{237} \mathrm{He}$ writes that spiritual beauty 'consists in the conduct or action of a man being well proportioned according to...reason' ${ }^{238}$ There is also a psychological sense of the quality of proportion, for St. Thomas. He writes:

\footnotetext{
${ }^{233}$ Ibid. Ia 12,1 ad 4.

${ }^{234}$ In Div. Nom. IV, 6.

${ }^{235}$ Ibid.

${ }^{236}$ Ibid. IV, 5.

${ }^{237}$ ST IIa-IIae 145, 2.

${ }^{238}$ Ibid.
} 
The beautiful consists in due proportion because the senses delight in duly proportioned things as similar to themselves, for the sense is a kind of reason [ratio], as are all the cognitive powers. ${ }^{239}$

In his Études d'Ésthétiques Mediévales (1946), Edgar de Bruyne points out that the idea that the soul enjoys the beautiful because the latter reflects its own harmony was common in medieval aesthetics. ${ }^{240}$ As St. Thomas formulates this idea, the intellectual character of his understanding of beauty becomes apparent. He asserts that proportion indicates rational order (ratio), and that the soul enjoys things so constructed because its own powers are also formed according to a rational order.

Thomas' third criterion for the beautiful is that of clarity. In the Commentary on the Divine Names, he writes that God gives beauty to all created beings insofar as he is the cause of their clarity. This can be said insofar as God 'sends into all creatures, along with a certain brightness [fulgore], a distribution [traditionem] of his luminous ray, which is the fount of all light ${ }^{241}$ These gifts of the divine ray, Thomas writes, are to be understood secundum participationem similitudinis, as a participation in the likeness of the divine splendour. He calls them pulchrificae, which is to say that they make creatures beautiful. He puts this more precisely by saying:

All form, through which things have being, is a certain participation in the divine clarity. ${ }^{242}$

It is through their form that things participate in the likeness of the divine splendour. As Aquinas says elsewhere, "beauty properly pertains to the concept of formal cause'. ${ }^{243}$ We need now to distinguish two more senses of the term

\footnotetext{
${ }^{239}$ Ibid. Ia 5, 4 ad 3.

${ }^{240}$ Edgar de Bruyne, Études d'Ésthétique Mediévale Vol. III, 'Le XIIIe Siècle' (Bruges: De

Tempel, 1946) p. 302.

${ }^{241}$ In Div. Nom. IV, 5.

${ }^{242}$ Ibid.

${ }^{243}$ ST Ia 5, 4 ad 1.
} 
'form' in St. Thomas' thought. First, it denotes that by which a substance has actual existence. In De Principiis Naturae (c. 1250), Thomas writes, 'Just as anything potential can be called material, so anything that gives existence...can be called form. Because forms make things actual, they are called acts'.244 Second, form is that by which a thing is the kind of thing it is. In his commentary on Aristotle's Metaphysics (1269-1272), Thomas writes, 'It is in virtue of form that the thing made up becomes... a 'this something' [hoc aliquid]' ${ }^{245}$ In the Summa Theologiae he writes, 'Everything is what it is by its form' (unumquodque sit id quod est per suam formam). ${ }^{246}$ It is this organising principle, by which a thing both exists and exists as the kind of thing that it is, that Aquinas calls a beautifying participation in the divine clarity. He describes it as 'a certain radiation deriving from the first clarity'. ${ }^{247}$

Thomas knew from Albert's De Pulchro et Bono that the beautiful consisted in the shining or splendour of form (splendor formae) in matter. Albert wrote, 'The essence of the beautiful in general consists in the resplendence of form [resplendentia formae] over proportionate parts of matter'. ${ }^{248}$ Thomas writes, 'Particular things are beautiful according to their own principle [rationem], that is, according to their own form ' ${ }^{249}$ Form, that is, from which clarity derives, is a rational principle. ${ }^{250}$ We saw that proportion consisted in the determination of a thing according to reason. This is why St. Thomas usually describes clarity and proportion together. Due proportion consists in a thing's determination by

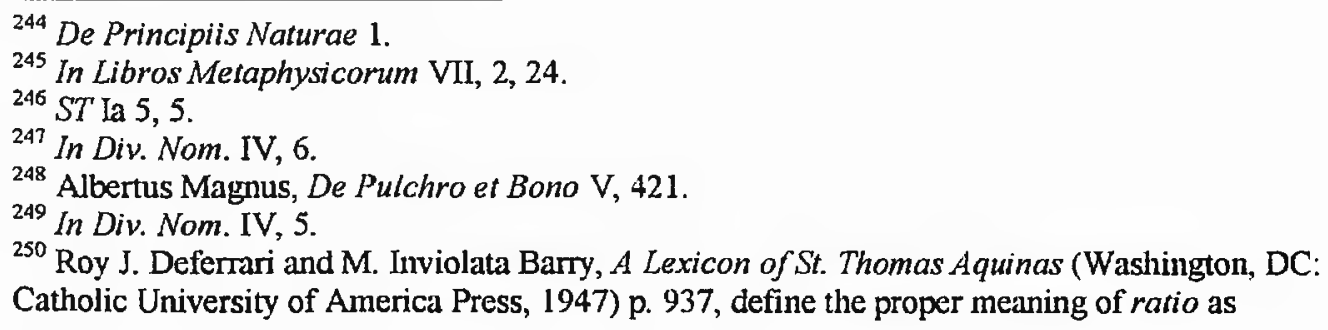


reason, and clarity is the rational principle in a thing. As we saw, Thomas distinguishes between spiritual and corporeal beauty. He continues, 'Each thing is called beautiful according as it has clarity in its kind [sui generis], whether spiritual or corporeal'. ${ }^{251}$ Again, Thomas' favourite example of the latter is the human body, whose clarity consists in bright colour (quadam coloris claritate; clarum et nitidum colorem). ${ }^{252}$ De Bruyne points out that in medieval physiology, the soul was held to preside over the mix of humours and thus over the composition of the blood, which was in turn responsible for the colour of the complexion. The latter was thus comprehensible as the shining out of an internal physiological order or ratio maintained by the soul. ${ }^{253}$ Thomas defines spiritual beauty as the state in which a man's action is well proportioned 'according to the spiritual clarity of reason' ${ }^{254}$ Elsewhere he writes that intemperance is the most disgraceful $\sin$ because "the pleasures... of intemperance dim the light of reason from which all the clarity and beauty of virtue arises' ${ }^{255}$ The ordered acts of a good moral life manifest the principle of reason by which they are ordered. This intelligibility of the ratio of a thing's form is what St. Thomas means by its clarity. As Armand Maurer writes, forms 'enlighten us as to what things are; and so it is natural to think of [them] as a kind of light'. ${ }^{256}$

As the concept of intelligibility indicates, St. Thomas' definition of beauty denotes the relation between a knowing subject and the formal properties of the objects of his knowledge. In De Pulchro et Bono, Albert wrote that the clarity of

\footnotetext{
'reason', and continue, 'From this proper meaning the term is extended to many other things all more or less connected with man in his specific nature as rational'.

${ }^{251}$ In Div. Nom. IV, 5.

${ }^{252}$ ST Ila-Ilae 145, 2; In Div. Nom. IV, 5.

${ }^{253}$ de Bruyne, Études d'Éstétique Mediévale III p. 309.

${ }^{254}$ ST IIa-Ilae 145, 2.

255 Ibid. IIa-IIae 142, 4.

${ }^{256}$ Maurer, About Beauty p. 9.
} 
virtue renders it beautiful 'even if it is not known by anyone' ${ }^{257}$ For Thomas, by contrast, 'we call those things beautiful which please when seen' (pulchra...dicuntur quae visa placent) and say that something is beautiful 'whose very apprehension is pleasing' (cuius ipsa apprehensio placet). ${ }^{258}$ The beautiful is that which, by virtue of the qualities we have examined, gives pleasure to the perceiving subject. It seems clear from the following passage of the Summa that the terms visio and apprehensio have the same meaning with respect to aesthetic pleasure:

The word 'vision' [visio] originally applied to the act of sense of sight. Because of the dignity and certitude of this sense, the word was extended... to the knowledge imparted by the other senses [cognitionem aliorum senstum]... and even to intellectual knowledge [cognitionem intellectus]. ${ }^{259}$

Aesthetic perception for St. Thomas is essentially intellectual. The form of the object must be known by the intellect. The beautiful is known through the senses of sight and hearing, because they are the senses which give most knowledge (maxime cognoscitivi sunt). ${ }^{260}$ It is for this reason that, although everything is beautiful insofar as it exists, we do not immediately perceive everything as beautiful. Such perception occurs when, to use Umberto Eco's phrase, in The Aesthetics of Thomas Aquinas (1970), we perceive something sub specie pulchri, in its beautiful aspect. ${ }^{261} \mathrm{~A}$ thing is beautiful when seen when it is seen as beautiful, that is, when its integrity, proportion and clarity are understood. To understand a thing's integrity, it is necessary to compare it to our idea of what it ought to be. To understand its proportion and clarity, it is necessary to discern

\footnotetext{
${ }^{257}$ Albertus Magnus, De Pulchro et Bono V, 426. See de Bruyne, Études d'Éstétique Mediévale III pp. 161-173.

258 ST la 5, 4 ad 1; Ia-IIae 27, 1 ad 3.

${ }^{259}$ Ibid. Ia $67,1$.

${ }^{260}$ Ibid. Ia-IIae 27, 1 ad 3.

261 Umberto Eco, The Aesthetics of Thomas Aquinas, tr. Hugh Bredin (Cambridge, Mass:

Harvard University Press, 1970) p. 191.
} 
the rational principle of its formal organisation. It is only when these judgmental labours are performed that a thing's beauty is apparent to us.

St. Thomas' theory of beauty contains several principles that can be used in a contemporary theory. We can take from him the principle that God is the most beautiful of beings. Since $\mathrm{He}$ is the cause of beauty in creatures, $\mathrm{He}$ is 'beautiful beyond being', that is, beautiful in a more eminent way than beautiful creatures. Creatures are beautiful by participation in the divine beauty, according to their individual natures. We do not need to accept the metaphysical system in which the beautiful is called a transcendental as a principle of Christian thought in general, but we can follow St. Thomas in asserting that the beauty of a literary work is a participation in the divine beauty. St. Thomas' definition of beauty is intimately bound up with his Aristotelian metaphysics, but we can still use some of its elements without implying a commitment to this metaphysics. Christian criticism could use the criterion of integrity in judging a work's beauty, that is, the degree to which a work is and does what we believe that it should be and do, although we will have to look elsewhere than Thomas' aesthetics to suggest what that might be. We can no longer use the criterion of proportion in St. Thomas' sense of a rational distribution of parts, nor that of clarity as the rational principle of form, but we can translate these two concepts into less rationalistic terms, and think of a work's determination by a mind in general rather than by the rational faculty in particular as its proportion, and of the visibility of this determination as its clarity. We can follow St. Thomas in asserting that these qualities please us when understood, although we need not suggest that they are the only qualities which do so. 


\section{St. Thomas' Theory of Art}

St. Thomas' longest discussion of art occurs in the question of the Summa that deals with intellectual virtues, or dispositions of the intellect towards good activity. Prudence (prudentia) is the disposition or habit of the intellect which directs actions according to right reason. Thomas calls it recta ratio agibilium, right judgement about things to be done. ${ }^{262}$ It presupposes that a man is rightly disposed towards his end, and is the virtue by which, in a given situation, he chooses a course of action directed towards that end. ${ }^{263}$ Art (ars), on the other hand, Thomas calls recta ratio factibilium, right judgement about things to be made. The end of art is the good of the works to be made (bonum... operum artificialum), and it is the virtue by which, in a given situation, an artist makes a good work, an object that is all it should be (in se bonum est). ${ }^{264}$ The good of the work pertains to that for which it is made. Thomas writes:

Every artist intends to put the best arrangement into his work - not absolutely but with respect to its end [per comparationem ad finem]. ${ }^{265}$

So if he is making a saw, whose purpose is to cut, he makes it out of iron, which is suited to cutting, rather than of glass, although the latter is the more beautiful material. This definition of art includes all the kinds of production we would call craft or technology, extending from poetry through shipbuilding to military strategy. 266

St. Thomas describes such production as analogous to the creative activity of God. He writes, 'All natural things were produced by the divine art, and so may

\footnotetext{
${ }^{262}$ ST la-IIae $57,4$.

263 Ibid. Ia-Ilae 57, 5.

264 Ibid. $574 ; 57,3$.

265 lbid. Ia 91. 3.

${ }^{266}$ See In Libros Ethicorum VI, iii, 12-19.
} 
be called God's works of art' ${ }^{267}$ It is because of this that Thomas can say that 'art imitates nature in its operation [in sua operatione]'. ${ }^{268}$ Natural processes in the body combat sickness by various means, and the art of medicine imitates these processes. Natural objects proceed by determinate means towards their proper ends, and hence appear to be works of intelligence. Art imitates this process (in operando...imitatur), by making things suited to their proper ends through determinate means. ${ }^{269}$ These can be called works of the artist's intelligence. Thomas writes, 'Natural things depend on the divine intellect just as artificial things depend on the human intellect'. ${ }^{270}$ Whilst art imitates the operation of nature, it is nevertheless ontologically dependent upon nature. Thomas writes:

Art is deficient in comparison with the operation of nature, because nature gives substantial form, which art cannot do. All artificial forms are accidental. $^{271}$

Substantial form is comprised by the two senses of form we distinguished above, namely that by which a thing both exists and exists as the kind of thing it is. Accidental form is that by which a thing is a certain kind of the kind of thing it is. $^{272}$ A man's humanity is his substantial form; his wisdom and weight are accidental forms. By saying that artificial forms are accidental, St. Thomas means that art does not bring anything into existence. Rather, it re-arranges the outward appearance of an already existent substance. As he writes in De Principiis Naturae, 'art can only operate on something which is already naturally in being [constitutum est in esse a natura]'. ${ }^{273}$ The artist transforms natural

\footnotetext{
${ }^{257}$ ST la $91,3$.

${ }^{268}$ Ibid. Ia 117, 1.

${ }^{269}$ In Libros Physicorum II, iv, 5.

${ }^{270}$ ST la $17,1$.

271 Ibid. IIIa 66, 4 .

${ }^{272}$ See ibid. Ia 77,6 .

${ }^{273}$ De Principiis Naturae 1.
} 
substances into works of art, such as copper into a statue or language into a poem.

The Middle Ages did not have a theory of the fine arts, that is, of works whose end is their own beauty as opposed to practical use. St. Thomas employs the standard medieval distinction, which derived ultimately from Aristotle, between the liberal and the servile or mechanical arts. ${ }^{274}$ The latter are directed towards works done by the body (opera per corpus exercita). They are called servile since the body is subject in a servile manner to the soul (serviliter subditur animae), with respect to which man is free. ${ }^{275}$ The liberal arts are called arts by a certain analogy (per quamdam similitudinem) with them. These are habits of the speculative reason which involve a certain degree of work (cuiusdam operis), such as the construction of a syllogism in the art of logic or the construction of an eloquent discourse in the art of rhetoric. Composition of a piece of music, in this taxonomy, is a liberal art, whilst playing a musical instrument is a servile art.

St. Thomas did not distinguish arts that tended towards beauty from arts that tended towards the useful, as we do. Nevertheless, we cannot say with Wladyslaw Tatarkiewicz, in his History of Aesthetics (1970), that 'St. Thomas'...theory of art was not concerned with beauty ${ }^{276}$ On the contrary, as de Bruyne points out, for St. Thomas all the arts tended towards beauty. ${ }^{277}$ This is firstly because each art tends towards a definite end, namely the perfection of the work to be made. Thomas writes, 'Since making passes into external material, its perfection is that of the thing made [perfectio...facti] ${ }^{278}$ This means

\footnotetext{
${ }^{274}$ See Aristotle, Politics VIII, $21337 \mathrm{~b}$

275 ST la-liae 57, 3 ad 3.

276 Wladyslaw Tartarkiewicz, History of Aesthetics Vol. II: Medieval Aesthetics, tr. R.M. Montgomery (The Hague and Paris: Mouton, 1970) p. 253.

277 de Bruyne, Études d'Éstétique Mediévale III p. 336.

${ }^{278}$ ST Ia-IIae 57, 5 ad 1.
} 
that all the arts tend towards integrity and so towards beauty in Thomas' system. Secondly, an artistic form is beautiful by virtue of its being. Insofar as it exists, the form of the art-work has the beautiful qualities of integrity, proportion and clarity. It has these qualities in the degree to which its perfection is realised.

St. Thomas has a low view of the capacity of poetry to impart knowledge. He writes that it is proper to poetry to proceed by means of various similitudes and representations (similitudines varias et repraesentationes) ${ }^{279}$ This process is the lowest of all kinds of teaching (infima inter omnes doctrinas), because it obscures the truth (veritas occultatur). ${ }^{280}$ Thomas writes that "poetic expressions [poetica] are not grasped by human reason, because of the lack of truth [defectum veritatis] in them ${ }^{281}$ Such expressions are employed in Scripture for several reasons, according to Thomas. Scripture's purpose is to reveal spiritual things under the likeness of corporeal things. Hence the 'sensible figures' (figuras sensibiles) of poetic imagery are a fitting way for it to proceed. Further, it is intended for all, both those who can understand intelligible things in themselves and those who cannot. Its sensible figures are fitting for the latter group's instruction. ${ }^{282}$ The value of poetry for St. Thomas derives from its capacity to impart pleasure. He writes, 'Representation is naturally delightful [delectabilis] to man'. ${ }^{283}$ Poetry belongs among those arts that have recreation (ludus) as their proper end, along with drama (officium histrionum) and secular music. Thomas writes that 'recreation is necessary for the conduct [conversationem] of human life' ${ }^{284}$ The soul needs rest just as the body does,

\footnotetext{
${ }^{279}$ Ibid. Ia 1,9 ob. 1.

${ }^{280}$ Ibid. Ia 1,9 ob. 2.

281 Ibid. Ia-IIae 101, 2 ad 2.

${ }^{282}$ Ibid. Ia 1, 9. Cp. Ia-Ilae 101, 2 ad 2.

283 Ibid. Ia 1,9 ad 1.

${ }^{284}$ Ibid. Ila-IIae 168, 3 ad 3.
} 
and finds it in 'words and deeds wherein nothing further is sought than the soul's delight [delectatio] ${ }^{285}$ Such playful and humorous things (ludicra et iocosa) give a certain necessary rest to the soul. It is here, for St. Thomas, that the delectatio of representation, which is the function of poetry, finds its proper place.

There is much in St. Thomas' theory of art that we can and should use in contemporary Christian literary theory. We can take from him the principle that artistic production is analogous to the creative activity of God, and can understand literary production as an imitation of the work of the divine author. We can also take from St. Thomas the principle that the art of literary production is an operation on the natural material of language, and so is a continuation of the work of the divine art which brought this material into being. St. Thomas has a deeply social view of art, much of which is ethically appropriate to Christian literary theory. We can follow him in understanding literary creation as one of the many kinds of production by which society is sustained. We can take from his definition of the liberal arts that it is a kind of labour, whose nature is partly physical. St. Thomas reminds us of the essential role of the body in the production of a work of literature. Finally, we can agree with St. Thomas that one of the ends of a literary work is recreation. Our minds, like our bodies, grow tired after a day's labour, and the pleasure we take in fiction is a useful means of resting them.

This concludes my analysis of the contribution to literary theory of these fundamental texts of the Western Christian tradition. I have argued that, despite

${ }^{285}$ Ibid. IIa-IIae 168, 2. 
the specific metaphysical frameworks in which the thought of Augustine and Aquinas is expressed, there are many principles both of their semiotics and of their aesthetics that we can assimilate into a contemporary Christian literary theory. I have also argued that the Bible implies certain propositions with respect to language and to art that should be so assimilated. I have been concerned with what Christian literary theory has been, and with how we can use this tradition of thought today. In the next chapter, I will turn to an examination of modern literary and aesthetic theories that either derive from Christian theology or are compatible with such theology, and I will assess how we can integrate these modern insights with those of the Christian tradition that we have examined here 


\section{Modern Christian Literary Theories}

In this chapter, I will examine some of the main twentieth-century currents of Christian thought in literary theory. As in the previous chapter, there are two purposes to this examination. I aim firstly to show that a tradition of Christian literary theory has existed throughout this century, and secondly to assess the degree to which the various insights of this tradition can and should be used in a contemporary theory. I will examine what I take to be the three most significant areas of modern thought for Christian literary theory, namely hermeneutics, neoThomism and the study of religion and literature.

\section{(i) Hermeneutics}

Hermeneutics, or the theory of interpretation, provides an account of our understanding of the meaning of the texts on which Christian faith is based. Hermeneutics as a science developed primarily through reflection the meaning of the Bible, reaching 'its first major formulation in the course and the after-effect of the Reformation', particularly in the work of the Protestant theologian Matthias Flacius (1520-1575). ' Friedrich Schleiermacher (1768-1834) developed theories of Biblical and classical exegesis into a discipline concerned with the interpretation of texts in general. ${ }^{2}$ In this section, I will examine the

\footnotetext{
' Josef Bleicher, Contemporary Hermeneutics: Hermeneutics as Method, Philosophy and Critique (London and Boston: Routledge and Kegan Paul, 1980) p. 12.

${ }^{2}$ See Paul Ricoeur, 'The Task of Hermeneutics', in Hermeneutics and the Human Sciences, tr. John B. Thompson (Cambridge and Paris: Cambridge University Press and Éditions de la Maison des sciences de l'Homme, 1981) pp. 45-48.
} 
hermeneutics of Hans-Georg Gadamer (b. 1900), in order to establish what Christian literary theory can learn from his thought with respect to the interpretation both of the Bible and other Christian texts and of literary texts.

\section{Gadamer's Theory of Authority and Tradition}

Gadamer was a student of Martin Heidegger (1889-1976) at the university of Marburg, and his hermeneutic theory is influenced by Heidegger's concept of understanding expressed in Being and Time (1927). Heidegger describes understanding not as the cognition of an object by a subject but as a fundamental characteristic of human existence in the world, or Dasein. ${ }^{3}$ He thinks of understanding as a non-reflective grasp of the possibilities for action, and therefore of becoming, determined by a given situation. ${ }^{4}$ This grasp becomes reflection in the process of interpretation (auslegung), by which things are understood as things. Heidegger argues that this process takes place against a background of meaningfulness, which he calls the 'fore-structure' of understanding. He explains that, in order for something to be understood as something, there must be a grasp of the situation in general in which it appears (which he calls 'fore-having', because we 'have' an understanding of the situation in which a thing takes on meaning for us), a pre-determined way of approaching the situation ('fore-sight'), and an existing system of concepts in whose terms the thing can be understood ('fore-conception'). ${ }^{5}$ This means that

\footnotetext{
${ }^{3}$ Martin Heidegger, Being and Time, tr. John Macquarrie and Edward Robinson (London: SCM Press, 1962) p. 182.

${ }^{4}$ See ibid. pp. 182-188. See also David Couzens Hoy, 'Heidegger and the Hermeneutic Turn', in Charles B. Guignon, ed., The Cambridge Companion to Heidegger (Cambridge: Cambridge University Press, 1993) pp. 170-194.

${ }^{5}$ Heidegger, Being and Time p. 191.
} 
understanding is circular, since 'any interpretation which is to contribute understanding must already have understood what is to be interpreted ${ }^{6}{ }^{6}$ This circularity, for Heidegger, is a fundamental characteristic of all human being in the world, and he calls it 'the existential fore-structure of Dasein itself" .

In Truth and Method (1960), Gadamer develops this concept of the forestructure of understanding as a characteristic of human existence by means of a study of the traditional field of hermeneutics, the human sciences. The principal argument of his book is that the empirical method of observation and induction used in the natural sciences is not the only means of inquiry with a valid claim to truth, but that the human sciences are also 'modes of experience in which a truth is communicated ${ }^{8}{ }^{8}$ Whilst this truth cannot be verified by empirical method, it can nevertheless be legitimated by a 'more profound investigation of the phenomenon of understanding,. ${ }^{9}$ Gadamer argues that any interpretation of the past is as conditioned by its specific historical situation as the past object or text itself. We bring our own systems of assumptions and presuppositions to interpretation, he asserts, which determine in advance the objects we select for investigation and the kind of questions we ask. Gadamer calls these presuppositions 'prejudices' (Vorurteile), and writes that, 'all understanding inevitably involves some prejudice'. ${ }^{10} \mathrm{He}$ argues that such prejudice is determined by the same historical process as the texts that we interpret. He writes:

\footnotetext{
${ }^{6}$ Ibid. p. 194.

? Ibid. p. 195.

${ }^{8}$ Hans-Georg Gadamer, Truth and Method, tr. William Glen-Doepel (London: Sheed and Ward, 1975) p. xii

${ }^{9}$ Ibid.

${ }^{10}$ Ibid. p. 239.
} 
Understanding is not...so much an action of one's subjectivity... as the placing of oneself within a process of tradition in which past and present are constantly fused. ${ }^{11}$

Historical texts can only be understood if the effect (Wirkung) of history in understanding, which Gadamer calls ‘effective-history’ (Wirkungsgeschichte), is taken into account. ${ }^{12}$ Such 'effective-historical consciousness', he argues, is a condition of validity in interpretation.

Gadamer writes that the Enlightenment's critique of prejudice was directed primarily against dogmatic interpretation of the Bible. ${ }^{13}$ It was the aim of Enlightenment thinkers to understand the Bible without prejudice and according to reason alone. Gadamer argues that this attitude is also a prejudice, historically determined in the same way as the Bible and Christian tradition. He writes, 'The idea of an absolute reason is impossible for historical humanity'. ${ }^{14}$ Given the historical nature of human existence, that is, there are no acts of interpretation that are not determined by a system of prejudices itself determined by the interpreter's position in history. Gadamer describes this position as the interpreter's situation in tradition, by which he means that it is impossible to encounter the past without already having been affected by it.

This encounter, for Gadamer, is a process of testing the prejudices that determine the conceptual scope or 'horizon' of the present against those that determine the horizon of the past, and vice versa. He calls this process the 'fusion of horizons' (Horizontverschmelzung). ${ }^{15}$ It can lead to valid interpretation, Gadamer argues, because there are such things as clegitimate

\footnotetext{
"Ibid. p. 258.

${ }^{12}$ Ibid. pp. $267 \mathrm{ff}$.

${ }^{13}$ Ibid. p. 241.

${ }^{14}$ Ibid. p. 245

${ }^{15}$ Ibid. p. 273.
} 
prejudices'. ${ }^{16}$ Some prejudices are an obstacle to knowledge, that is, but others produce it. The Enlightenment thought of authority in the former sense, as an inhibition of reason and an impediment to knowledge. Gadamer calls this a subjection of authority to reason. He writes that whilst it can be a source of misjudgement, it can also be a source of truth. ${ }^{17}$ Authority is misunderstood, he argues, as the opposite of reason and freedom. It is essentially a source of knowledge, based on a recognition "that the other is superior to oneself in judgement and insight and for that reason his judgement takes precedence over one's own'. ${ }^{18}$ This is a free and rational act, Gadamer argues, when what the authority states 'can be seen, in principle, to be true'. ${ }^{19}$ In this sense, authority is granted to a teacher or to a professional specialist. Gadamer writes, 'The prejudices that they implant are legitimised by the person himself'. Hence he calls them 'objective prejudices' ${ }^{20}$ For Gadamer, acceptance of authority is a logical correlative of human finitude. Since I do not know everything, it is in principle true that another may have something to teach me. He argues this point with respect to tradition as a source of authority, that the choice to preserve the truth-claim of certain past assertions can be as free and rational as the choice to reject that of others.

Gadamer's theory of authority and tradition provides the conceptual basis of a response to the objections of rationalism and post-structuralism to Christian hermeneutics, that is, to the interpretation of Scripture in the community of Christian faith and the interpretation of literary texts in the terms of that faith. Gadamer's argument that all acts of interpretation are in part determined by the

\footnotetext{
${ }^{16}$ Ibid. p. 246.

${ }^{17}$ Tbid. p. 247.

${ }^{18}$ Ibid. p. 248

${ }^{19}$ Ibid. p. 249
} 
acceptance on authority of some traditional statements implies that Scriptural interpretation determined by Christian traditions is not an irrational or unusually prejudiced practice. We can accept from Gadamer the principle that no interpretation takes place outside some traditionally determined community, and that Christian hermeneutics, as I have defined it, is an example of rather than an exception to this rule. The ascription of authority to Scripture and Christian traditions within the Christian community is, when made consciously, a free and rational choice, and one in whose nature all acts of interpretation in fact participate. We can accept from Gadamer the principle that no act of interpretation is not determined by the acceptance of the truth-claim of some past text or texts as authoritative, and that, again, Christian hermeneutics is an example of and not an exception to this rule. We can assert as a result that Christian literary theory is a legitimate mode of contemporary literary theory.

\section{The Gadamer-Habermas Debate}

Gadamer's ideas have been criticised on several fronts. In Validity in Interpretation (1967), E. D. Hirsch Jr. argues that Gadamer's insistence on the historical situation of all understanding leads to a relativism in which no understanding can be validated over another. ${ }^{21}$ Gadamer himself is careful to ward off this charge, taking up a position that David Couzens Hoy, in The Critical Circle (1978), describes as 'contextualism'. ${ }^{22}$ Hoy defines this in contrast to 'subjectivistic relativism', according to which statements concerning

\footnotetext{
${ }^{20}$ Thid.

${ }^{21}$ E.D. Hirsch. Jr., Validity in Interpretation (New Haven: Yale University Press. 1967) pp. 245264.
} 
the meaning of a text refer in fact to the meaning of the text to the person making the statement. According to contextualism, however, whilst no context for interpretation can be absolutely validated, some contexts are more appropriate than others at a given time. For Gadamer, whilst all interpretation is conditioned by the situation of the interpreter, consciousness of this situation can be used to justify the interpretation, although such justification remains partial, since noone can be conscious of all his or her prejudices. Gadamer uses Aristotle's concept of practical wisdom and the practice of legal hermeneutics to support this position. ${ }^{23}$

A more serious charge, particularly with respect to the use I am making of Gadamer's thought, comes from the Frankfurt school of Critical Theory. In his book On the Logic of the Social Sciences (1967), Jürgen Habermas (b. 1929) levels two criticisms at Gadamer's theory of authority and tradition, the essence of both of which is that it is conservative and excludes the possibility of critique. He criticises Gadamer's ontological conception of hermeneutics, whereby his concern is the fundamental experience of understanding rather than its misconception by the human sciences. Whilst the latter is a valid enterprise, according to Habermas, the opposition between hermeneutical experience and scientific method is not absolute. Having criticised the absolute claims of empirical science, Habermas argues, a hermeneutic theory of its method is necessary. He writes, 'The claim [of hermeneutics against method], we must fear, will be effective either in the sciences or not at all'. ${ }^{24}$ In Habermas' view, it

\footnotetext{
${ }^{22}$ David Couzens Hoy, The Critical Circle: Literature, History and Philosophical Hermeneutics (Berkeley and London: University of Califomia Press. 1978) p. 69.

${ }_{23}$ Gadamer, Truth and Method pp. 278-305.

${ }^{24}$ Jürgen Habermas, On the Logic of the Social Sciences, tr. Sherry Wicber Nicholsen and Jerry A. Stark (Cambridge: Polity Press, 1988) p. 167.
} 
is necessary to develop a hermeneutical consciousness of scientific method, in order that it can become an object of critical analysis.

His second criticism is that Gadamer is too sanguine about the lack of opposition between reason on one hand and authority and tradition on the other. He questions Gadamer's validation of the recognition of authority as a rationally chosen act of knowledge, asking, 'Does it follow from the unavoidability of hermeneutic anticipation that there are legitimate prejudgements? ${ }^{25}$ Gadamer is forgetting about ideology, in Habermas' view, and so participating in its perpetuation. Habermas is sceptical about the approval with which Gadamer describes the acceptance of tradition in the structure of understanding. The prejudices which structure one's interpretation of the past may well be false, he argues, and Gadamer takes no account of this possibility. Habermas writes, 'Reflective appropriation of tradition breaks the quasi-natural [naturwüchsige] substance of tradition and alters the position of subjects within it'. ${ }^{26} \mathrm{He}$ argues that, in addition to becoming conscious of one's own prejudices, one can come to recognise their origins, and as a result to accept or reject them with an adult reason. A known prejudice, that is, no longer functions as a prejudice. Gadamer illustrated the legitimacy of authority with the example of the student's relation to the teacher. Habermas argues that such prejudices are inculcated, "however we want to look at it, under the potential threat of sanctions and with a view to gratification'. ${ }^{27}$ A student doesn't simply accept what he is taught; he has no choice. Family, education, and legal systems all demand that he does so. As he becomes an adult, however, he can reflect on the prejudices that he has internalised in the course of his education, and accept or reject them on rational,

\footnotetext{
${ }^{25}$ Ibid. p. 169.

${ }^{26}$ Ibid. p. 168.
} 
and not simply authoritative, grounds. The idea of the legitimacy of certain prejudices, validated by tradition, Habermas writes, 'is in conflict with the power of reflection, which proves itself in its ability to reject the claim of traditions'. ${ }^{28}$ It is an illustration of this point, he argues, that hermeneutics arose as a science at the Reformation, precisely when the binding nature of Catholic traditions began seriously to be questioned.

In his essay 'On Hermeneutics' Claim to Universality' (1970), Habermas further contests the claim of Gadamer's hermeneutics that it includes in its field the kind of critical reflection on tradition that Habermas has in mind. He cites examples of the limits of hermeneutic understanding, principally the systematic distortion of communication that psychoanalysis and ideology-critique find occurring in ordinary language. ${ }^{29}$ He pursues the model of psychoanalysis, which finds that even apparently normal speech is in fact distorted communication. In the analytic situation there occurs a systematic production of misunderstanding, which an ontological hermeneutics cannot comprehend. It takes a theory to understand these expressions, a knowledge of the determinants of their distortion. Habermas accepts Gadamer's assertion that all misunderstanding presupposes a prior agreement, but argues that his concept of tradition ignores the fact that this agreement itself may be a product of pseudo-communication, that is, of specifically determined misunderstanding. There is a distinction between true consensus and the false consensus which is a product of compulsion, Habermas argues, and Gadamer's ontological hermeneutics cannot recognise it. He argues that Gadamer cannot guarantee that a prejudice handed

\footnotetext{
${ }^{27}$ Tbid. p. 169.

${ }^{28}$ Ibid. p. 170.

${ }^{29}$ Kurt Mueller-Vollmer, ed. The Hermeneutics Reader: Texts of the German Tradition from the Enlightenment to the Present (Oxford: Blackwell, 1985) pp. 302-312.
} 
down by tradition is not an example of distorted communication, which psychoanalysis and ideology-critique have shown to be prevalent forces in the language in which tradition is received.

Gadamer accepts Habermas' contention that tradition can be ideological, but he disagrees that is that it is always so. In response to Habermas' first criticism, that hermeneutics ought to concern itself with scientific method rather than oppose itself to it, Gadamer writes that he focussed on the human sciences because they were concerned with experience that lay outside the scope of scientific method. This is not to have abandoned method to positivism, he argues, but to assert that hermeneutic experience is prior to methodological concerns. ${ }^{30}$ Gadamer accepts that hermeneutics can function within the sciences but argues that it cannot be restricted to them. In response to Habermas' criticism concerning the ideological nature of tradition, Gadamer writes that the latter's claims for the power and scope of reflection are too strong. He is wrong to think that critical reflection on tradition can take place in a situation that is not itself determined by tradition. Gadamer writes:

Only a naive and unreflective historicism...would see the historicalhermeneutic sciences as something absolutely new that would do away with the power of tradition. ${ }^{31}$

In Gadamer's view, even critical reason is contained in the hermeneutic circle. In asserting otherwise, he writes, Habermas is returning to the prejudice of the Enlightenment in which 'reflection is granted a false power, and the true dependencies involved are misjudged on the basis of a fallacious idealism, ${ }^{32}$

\footnotetext{
${ }^{30}$ Hans-Georg Gadamer, Philosophical Hermeneutics, tr. David E. Linge (Berkeley and London: University of Califormia Press, 1976) p. 26.

${ }^{31}$ Ibid p. 29.

${ }^{32}$ Ibid. p. 33.
} 
Gadamer accepts that tradition can be a source of compulsion, however. He writes:

I would grant that authority exercises an essential dogmatic power in innumerable forms of domination, from the ordering of education... to the hierarchy of power created by political forces. ${ }^{33}$

He does not deny the possibility of an 'emancipating criticism of authority', but only that understanding necessarily involves such a criticism. ${ }^{34}$ For Gadamer, authorities are not always wrong, and so 'reflection is not always and unavoidably a step towards dissolving prior convictions', ${ }^{35} \mathrm{He}$ writes that Habermas has misunderstood him when he imputes to him the view that tradition is the only ground for the acceptance of presuppositions. In fact, Gadamer writes, "Tradition is no proof and validation of something... where validation is demanded by reflection'. ${ }^{36} \mathrm{He}$ argues that Habermas has not recognised the distinction between true and false authority, that is, between rational acknowledgement of the greater knowledge of another and submission to the power of another. Whilst one can be more or less consciously compelled to accept traditional statements, one can also freely choose to do so. Gadamer argues that one cannot reflect on everything, and that much is accepted from tradition that cannot be brought to light. It is becoming clear that there is little substantial disagreement between the two on the nature of tradition. Gadamer denies that reflection always involves the dissolution of what one has accepted, but Habermas has not said that this is the case. He accepts the possibility that one may endorse the data of tradition (in the way that he himself has accepted the Marxist tradition of ideology-critique, for example), but asserts that reflection

\footnotetext{
33 Ibid.

${ }^{34}$ Ibid. p. 34.

35 Ibid. p. 32

${ }^{36}$ Ibid. p. 34.
} 
alters it. ${ }^{37}$ When appropriated by reflection, knowledge received from tradition is no longer accepted on authority, and thus functions differently in hermeneutic activity. For his part, Habermas denies that tradition is always passed on without ideology, but Gadamer has not said that this is the case. He accepts that the data of tradition need validation by reflection, but denies that such validation does not take place. Both agree that reflection on tradition can result in the rejection of some of the prejudices it has inculcated, but that tradition can be a source of truth. They remain divided over whether hermeneutics or critique is the more fundamental discourse, but on the issue of tradition, despite a certain amount of misrepresentation, their positions are not dissimilar.

Nevertheless, their debate serves to emphasise an important aspect of Gadamer's hermeneutics for my argument that his theory can be used to validate Christian hermeneutics against rationalist and post-structuralist objections to it. It makes clear that to acknowledge the role of tradition in understanding is not to advocate a passive acceptance of the past but to describe a process of conflict between the past and the present, in which both are transformed in the encounter. Gadamer writes:

Every encounter with tradition...involves the experience of the tension between the text and the present. The hermeneutic task consists in not covering up this tension by attempting a naïve assimilation but consciously bringing it out. ${ }^{38}$

In his essay 'What is Tradition?' (1991), Gerald L. Bruns emphasises this aspect of Gadamer's theory, against the unified and institutional concept of tradition of which Habermas and others accuse him. He writes:

Tradition is seamed...as a conflict of interpretations that cannot be resolved or harmonised... but must rather be suffered or lived through.

\footnotetext{
${ }^{37}$ Habermas, On the Logic of the Social Sciences p. 169.

${ }^{38}$ Gadamer, Truth and Method p. 273.
} 
The suffering of such conflicts is basic to what Gadamer calls hermeneutical experience. ${ }^{39}$

Gadamer's responses to Habermas make clear that his acknowledgement of the role of authority and tradition in understanding is not one that entails political conservatism. We can take from them the principle that the data of Christian tradition from which I am arguing that Christian literary $\bigwedge^{\text {should derive need }}$ validation by reflection. Certain Christian doctrines and practices have been ideological, and reflection is necessary to establish which of them we should with adult reason accept and which we should reject. Essential to Gadamer's concept of a tradition is that this process of acceptance and rejection is not acceptance or rejection of the tradition but precisely the process by which it is constituted. Having accepted his assertion that tradition can be a source of truth, we can also accept his argument that it is not always or necessarily so.

\section{Gadamer's Poetics}

I will conclude this section with an examination of Gadamer's theories of art and of poetry. Gadamer compares the latter in particular with religious language, and I will assess the degree to which we can assimilate his conclusions into a contemporary Christian literary theory.

The critique of method in Truth and Method begins with an examination of art, the experience of which, according to Gadamer, constitutes a challenge to the exclusive claim to truth of scientific method. His thesis is that 'truth is

\footnotetext{
${ }^{39}$ Gerald L. Bruns, 'What is Tradition?', New Literary History 22 (1991) p. 12. In The Two Horizons: New Testament Hermeneutics and Philosophical Description with Special Reference to Heidegger, Bultmann, Gadamer and Wittgenstein (Grand Rapids, MI: Eerdmans. 1980) pp. 314-326, Anthony C. Thiselton emphasises the importance of the element of conflict in
} 
experienced through a work of art that we cannot attain in any other way'. ${ }^{40}$ This idea was lost with Kant's Critique of Judgement (1790), in which the experience of art was divorced from conceptual thinking. In Kant's thought, aesthetic pleasure is by definition unrelated to intellectual activity. It has, in Gadamer's words, 'an autonomous basis freed from the criterion of the concept'. ${ }^{41}$ This kind of aesthetic consciousness, Gadamer argues, in fact alienates the reader or viewer from the real or authentic experience of an art-work, for which in many historical periods it was clearly created, namely its claim upon him or her. ${ }^{42} \mathrm{He}$ writes:

The consciousness of art - the aesthetic consciousness - is always secondary to the immediate truth-claim that proceeds from the work itself. $^{43}$

Gadamer follows Heidegger in thinking of truth as the 'unconcealment" of a thing, as the '[bringing] to the light what otherwise is constantly hidden or withdrawn'. ${ }^{44}$ In this sense, he argues, the experience of art is an experience of truth, and not simply an experience of pleasure.

In his essay 'On the Contribution of Poetry to the Search for Truth' (1971), Gadamer argues that poetry can provide truth in this sense. He asserts that 'poetry is language in a pre-eminent sense', that is, that it is language most clearly revealed as such. ${ }^{45}$ This assertion is based on Heidegger's view that the Greek word for truth, alêtheia, connoted 'open-ness'. Gadamer writes:

This primary meaning of truth is that we tell the truth, we say what we mean. This is supplemented... by a further sense in which... whatever

Gadamer's understanding of historical interpretation for the use of his thought in New Testament hermeneutics.

${ }^{40}$ Gadamer, Truth and Method p. xii.

${ }^{41}$ Ibid p. 55 .

${ }^{42}$ Ibid. p. 112.

${ }^{43}$ Gadamer, Philosophical Hermeneutics p. 5

${ }^{44}$ Gadamer, Truth and Method p. 101.

${ }^{45}$ Hans-Georg Gadamer, The Relevance of the Beautiful and Other Essavs, tr. Nicholas Walker (Cambridge: Cambridge University Press, 1986) p. 106. 
shows itself to be what it is, is true... When we say 'real gold', for example, we mean that it not oniy glitters like gold but that it is gold. ${ }^{46}$

A true word, according to this definition of truth, is a word that reveals itself as a word, that really corresponds to the concept of a word. It is in this sense that the poetic word is a true word, for Gadamer. He has a high view of poetry, in which 'the text enjoys greater reality than any of its potential realisations'. ${ }^{47}$ By this he means that the written text of a successful poem primarily says itself rather than describing something prior to or external to itself. The reality to which it corresponds is that which it conjures up in each reader's imagination, rather than anything in the external world or in the author's mind, against which its truthcontent could be checked. Gadamer writes that 'it bears witness to itself and does not admit of anything that might verify it' ${ }^{48}$ Successful poetic language is revelation itself, he argues, and so 'stands out as the highest fulfilment of that revealing... which is the achievement of all speech' ${ }^{49}$ He writes that it is the goal of utterance to bring what was hidden into the light of shared understanding, and that poetic utterance fully realises this goal. In Gadamer's view, every statement acquires meaning from its situation in a more or less explicit dialogue, that is, from 'the question to which it supplies an answer' ${ }^{50}$ He writes that in the case of poetry, the 'nearness', that is, the intimacy and familiarity to us, of the things revealed in poetic language constitutes an implicit answer to the question of the temporality of our everyday experience. He writes:

Our fundamental experience as beings subject to time is that all things escape us... [But] the poetic word brings the transience of time to a standstill. ${ }^{51}$

\footnotetext{
${ }^{46}$ Ibid. p. 108.

${ }^{47}$ Ibid. p. 109.

48 Ibid. p. 110.

49 Ibid. p. 112.

${ }^{50}$ Tbid. p. 106.

sl Ibid. p. 114.
} 
Language, for Gadamer, is the means by which we make ourselves at home in the world, by which it becomes familiar to us. The truth of poetry, he argues, is that, in allowing us an experience of intimacy with the things it discloses, which is usually effaced by the passage of time, it reveals this very familiarity with the world in which language allows us to stand.

In his essay 'Aesthetic and Religious Experience' (1978), Gadamer examines the relation between poetic and religious language. He notes that the issue of the difference has arisen only in Judaeo-Christian cultures, in which a canon of holy texts has been established, and that in other cultures the distinction is not sharply drawn. He writes that the common quality of the language of poetry and religion in ancient Greek culture, before such a distinction was made, was that of 'myth', that is, that it was an 'intrinsically inexhaustible process'. ${ }^{52}$ Greek religion was transmitted primarily through poetry, and its content was re-interpreted by each new poet. Gadamer argues that this mythical tradition becomes literature with the evolution of the re-interpretable narration into the written work. He asserts that this process can be traced in Greek literary genres:

in the development of rhapsodic performance that went beyond ritual; in the choreographical staging of the choral lyric, which had certainly emerged from the observance of everyday religious practice; in the spectacle of tragedy, which...was embedded in the context of religious life. ${ }^{53}$

He argues that the religious text has evolved in the Christian West from the same kind of mythical narration into a 'proclamation', or binding document, and into a 'promise', which becomes meaningful insofar as it is accepted by the addressee. $^{54}$ Whilst poetic and religious texts are now different kinds of language, he continues, traces of their common origin remain. Both poetic and

\footnotetext{
${ }^{52}$ Ibid. p. 144.

${ }^{53}$ Ibid. p. 145.
} 
religious language have what Gadamer calls a 'symbolic' quality, in the sense that they can constitute "that through which someone or something is known or recognised'. 55 Literary works can arouse in their readers the experience that Gadamer calls "sthis is you", that is, a consciousness of something shared with the things revealed in the text. He writes that this 'an expansion of that infinite process of making ourselves at home on the world which is the human $\operatorname{lot}^{2} .{ }^{56} \mathrm{He}$ asserts that the reader of the Christian texts can have a similar experience, characteristically that of the poverty of Christ crucified. Despite this formal similarity, the Christian texts nevertheless differ from literary texts, in Gadamer's view. He describes this difference by means of the concept of 'sign', in the religious sense, that is, of "something only given to one who is ready to accept it as such' ${ }^{57}$ Unlike poetic language, he argues, the Scriptures have a truth-claim that is accessible only to a reader who is looking for and prepared to accept such a claim.

Gadamer's Romantic premise that the unity and autonomy of the written text are fundamental criteria of poetry cannot be accepted today without response to the objections that it effaces the social and political contexts of the text's production and receptions. This is lacking in Gadamer's work, and there is no reason for us to accept the premise. Nevertheless, there are certain elements of his comparison of religious and poetic language that we can use in Christian literary theory. We can accept his argument that the originally indistinct concepts of poetic and religious language have evolved into the discourses of literature and religion, which still retain traces of their common origin. We can follow

\footnotetext{
${ }^{54}$ Ibid. pp. 147-148.

${ }^{55}$ Ibid.

${ }^{56}$ Ibid. p. 151.

${ }^{57}$ Ibid. p. 152.
} 
Gadamer in asserting that many literary genres evolved from religious contexts whose traces can still be discerned in them. One of the tasks of Christian literary criticism might be to describe the mythical significance of a text's genre. Secondly, we can take from Gadamer the principle that in reading a literary text, a reader can come to understand more fully some previously obscure aspect of his or her existence. In this sense we can follow Gadamer in asserting that reading fiction can be an experience of truth. We can also follow him in comparing this process to reading Scripture. Whilst there are significant differences, fictional works, like Scripture, are a means by which readers make themselves at home in the world, and which can transform their beliefs and their actions in it.

\section{(ii) Neo-Thomism}

A second significant modern source of Christian literary theory is the revival of the thought of Thomas Aquinas that took place in the first half of this century. Maurice de Wulf, in an article on Neo-scholasticism (1913), describes the movement as follows:

Neo-scholasticism is... not merely the resuscitation of a philosophy long since defunct, but rather a restatement in our own day of the philosophia perennis which, elaborated by the Greeks and brought to perfection by the great medieval teachers, has never ceased to exist even in modern times. $^{58}$

What de Wulf calls neo-scholasticism and others neo-Thomism is a school of thought which seeks to apply scholastic or Thomistic principles to contemporary intellectual life in the belief that those principles remain true, despite the 
evolution of science and philosophy from the context in which they were first expounded. Neo-Thomist thought was officially sanctioned by the Catholic church in Pope Leo XIII's encyclical Aeterni Patris (1879), in which he called for the restoration of Christian philosophy by an application of the thought of St. Thomas to modern life. He wanted 'to restore the golden wisdom of St. Thomas, and to spread it far and wide for the defence... of the Catholic faith... and for the advantage of all the sciences'. ${ }^{99}$ The following year he established the Institut Supérieur de Philosophie at Louvain as a centre for Thomistic study, in which numerous and influential works on the 'perennial philosophy' were written. Succeeding popes Pius $\mathrm{X}$, Benedict $\mathrm{XV}$ and Pius XI reinforced the position of Aquinas in Catholic thought. In his encyclical Studiorum Ducem (1923), Pius XI wrote, 'The Church has adopted his philosophy for her very own'. ${ }^{60}$

\section{Jacques Maritain}

The most significant contribution to literary theory to come from the neoThomist movement was the philosophy of art and poetry of Jacques Maritain (1882-1973). Influenced by Henri Bergson, and a convert to Catholicism under the influence of Léon Bloy, Maritain was from his earliest years a friend of many of the leading poets, artists and musicians of his day, and he maintained a lifelong interest in the fine arts. In his first work of aesthetics, Art and Scholasticism (1920), he wrote that whilst the medieval Scholastic philosophers had devoted no treatises directly to art, 'there is nevertheless a far-reaching

\footnotetext{
${ }^{58}$ The Catholic Encyclopaedia, <http://www.knight.org/advent/cathen/10746a.htm>.

${ }^{59}$ Leo XIII, Aeterni Patris: On the Restoration of Christian Philosophy (1879) no. 31. $<$ http://listserv. american.edu/catholic/church/papal/leo.xiii/113cphi.txt>.

${ }^{60}$ Pius XI, 'Studiorum Ducem', Acta Apostolicae Sedis 15 (1923) p. 314.
} 
theory of art to be found in their writings, but it is to be sought in austere dissertations on some problem of logic... or of moral theology". ${ }^{61}$ Maritain set out to systematise this disparate material, and to outline the fundamental principles of a scholastic theory of art. He believed that it would meet the needs of aesthetics for honesty after the 'vast intellectual confusion' of nineteenthcentury aestheticism in which the 'fine' arts were considered in abstraction from the 'useful' arts, beauty was considered only in relation to art, and art was considered an end in itself. ${ }^{62}$ His thought increasingly turned to poetry, and to the nature of the knowledge embodied in a poetic work. His final work of aesthetics, Creative Intuition in Art and Poetry (1953), is a synthesis of his scholastic exposition and of his own concerns with such knowledge.

Maritain insists on the fundamental role of the intellect in art. The Aristotelian psychology he takes from St. Thomas distinguishes between the speculative and practical intellect. These are not two separate powers but different ways in which the one intellect operates. The object of the speculative intellect is simply knowledge. Maritain writes, 'The grasping of that which is, is its only goal' ${ }^{63}$ The object of the practical intellect, on the other hand, is to know how to act. This is the kind of knowledge that we put to use, rather than simply enjoying its truth. ${ }^{64}$ St. Thomas, following Aristotle, divided the activity of the practical intellect into two kinds, action and making, that is, moral and artistic activity. Action concerns the use of the will in terms of what is done with its freedom to choose, according to which a person can be judged good or bad. It is the sphere

\footnotetext{
${ }^{61}$ Jacques Maritain, Art and Scholasticism with Other Essays, tr. J.F. Scanlan (London: Sheed and Ward, 1934) p. 1.

${ }^{62}$ Ibid. p. 2.

${ }^{63}$ Jacques Maritain, Creative Intuition in Art and Poetry (London: The Harvill Press. 1953) p. 46.

${ }^{64}$ Art and Scholasticism p. 4
} 
of morality, guided by the virtue of prudence, which is 'the straight intellectual determination of actions to be done' ${ }^{65}$ Making, on the other hand, concerns things produced. It is ordered not to the good of the person making but of the work made. It is the sphere of art, in the scholastic sense, and is guided by the virtue of art, which is 'the straight intellectual determination of things to be made'.66

Art is not a virtue in the moral sense, in Maritain's thought, but in the psychological sense in which the Scholastics spoke of a habitus, or quality of mind. Habits are 'permanent conditions perfecting in the line of its own nature the subject they inform', ${ }^{67}$ Health is a habit of the body, grace a habit of the soul, and the moral and intellectual virtues are habits of the intellect. A habit in this sense is a 'state of possession', an inner strength in the activity of a given faculty. ${ }^{68} \mathrm{~A}$ habit of the intellect can be called a virtue in the sense that it sharpens an activity of the initially indeterminate intellect to perfection. In this sense the Scholastics called art a virtue of the practical intellect, meaning that it is an acquired disposition of the intellect fully to perform its capacity of making a work. Maritain writes, 'Manual dexterity is...no part of art, but merely a material and extrinsic condition... Art remains entirely by the side of the mind ${ }^{\text {" }}{ }^{69}$

Art in this sense is comparable to prudence, the virtue of the practical intellect concerned with right action. Prudence operates for the good of the worker, whereas art operates for the good of the work. Art, considered in the abstract, is unrelated to morality. If a jeweller makes a good brooch, the fact that he is jealous or avaricious is immaterial to the goodness of the brooch, which is the

${ }^{65}$ Creative Intuition p. 48.

${ }^{66}$ Ibid.

${ }^{67}$ Art and Scholasticism p. 9.

${ }^{68}$ Creative Intuition p. 49 
object towards which the virtue of art tends. Prudence presupposes a welldisposed will; it determines the means to an end whose goodness is a result of the disposition of the will. Art, on the other hand, works independently of a welldisposed will, since its end, the good of the work, is outside the sphere of human good. ${ }^{70}$ It is more closely related to the virtues of the speculative intellect, for a person can also be a good geometer and provide true demonstrations without being a good person. In practice, however, since a person is both a human being and an artist, the concerns of art and prudence will conflict. Prudence may tell a workman to return to his family at the end of the day, whilst art will tell him to keep working. Maritain writes, 'The artist will require a measure of heroism to keep always in the direct line of action and not to sacrifice his immortal substance to the devouring idol in his soul' ${ }^{71}$

Art, in this intellectual sense, has rules according to which it operates. Like the other virtues of the practical intellect, it works in conjunction with the will. A good will, or 'straight appetite', in art is a conformity of the will to these rules. This notion involves no neo-classical imposition of extrinsic rules upon art: Maritain dismisses this phase of literary history as a perversion both of art and of Aristotle. The rules of art in Maritain's scholastic sense are internal and descriptive. Maritain writes that they are 'not conventional imperatives imposed upon Art from without, but the...concealed ways by which Art itself, the working reason, goes to work', ${ }^{72}$ The rules of art are to the artist what his tools are to the workman. They are discovered by the intellect in the process of making. In the useful arts, Maritain writes, the initial rule is the will to satisfy a

\footnotetext{
${ }^{69}$ Art and Scholasticism p. 13.

${ }^{70}$ Ibid. pp. 15-16.

${ }^{71}$ lbid. p. 15.

${ }^{72}$ Ibid. p. 39.
} 
certain need, for example the need to cross a river. When the intellect conforms to this rule with the idea of a raft, and a man fashions one, a second rule, for making a raft, is discovered. When both rules are followed, it becomes clear that the raft can be improved in design, and a third rule according to which it can be improved is also generated. ${ }^{73}$ With each new design improvement, the intellect conceives a new rule according to which it can best be made. The rules of art Maritain thus describes as 'vital ways of operating discovered by the creative eyes of the intellect in its very labour of invention'. ${ }^{74}$

The predominant rule, according to Maritain, is always the need to be satisfied. The primary need in the case of the fine arts, he writes, is 'the release of the pure creativity of the spirit, in its longing for beauty'. ${ }^{75}$ It is in the nature of the intellect, he writes, to 'engender in beauty', to make a work in which it delights. He writes that this need to make a beautiful work is the first rule of fine art to which the will must conform if the work is to be good. All the subsequent rules, however, are far more contingent and particular than in the case of the useful arts. Beauty, like being, is infinite, and there is an infinite number of ways in which a work can participate in it. The rules of fine art are thus 'perpetually newborn', as each new participation in beauty requires new rules of making. ${ }^{76}$ In this they resemble the rules of prudence, which also have to deal with a unique situation each time they are used. Maritain argues that in making an art-work, the artist's will must be ordered towards beauty. He writes that people judge concerning their ends according to what kind of person they are. 'As a man is, so

\footnotetext{
${ }^{73}$ Creative Intuition p. 53.

${ }^{74}$ Ibid. p. 54.

${ }^{75}$ Ibid.

${ }^{76}$ Ibid. p. 57.
} 
does the end appear to him ${ }^{\text {}}{ }^{77}$ If I am a chaste man, I will want chastity. If I am to produce a work of beauty, I must want beauty. According to the Scholastic concept of connaturality, what I want, what my appetite tends towards, is also the kind of person that I am. The rule of fine art, for Maritain, is that a person must love beauty so that his or her intellect becomes co-natured with it. $\mathrm{He}$ writes that this is because in art, as in contemplation, 'intellectuality...goes beyond concepts...and is achieved through a...connaturality with the object, which love alone can bring about ${ }^{78}$ This connaturality occurs and a work of beauty is achieved through what Maritain will call 'creative intuition'.

Maritain understands beauty in a Thomistic sense, as id quod visum placet, that which pleases on being seen. Beauty is the quality in a thing which delights the intellect as it knows it. Of the three Thomistic criteria of the beautiful, Maritain privileges clarity, writing that beauty is the 'splendour of the form' of a thing, or 'the splendour of the secrets of being radiating into intelligence'. ${ }^{79}$ He says this because form, in the scholastic sense, does not refer to external form but to 'the inner ontological principle' which determines a thing as what it is. ${ }^{80}$ This principle is intelligible in itself, but not necessarily to us. Beauty can thus also be described as the splendour of the 'mystery' of a thing. As we saw in the fourth chapter, St. Thomas holds that beauty is an analogous concept, which means that different things are beautiful in different ways. ${ }^{81}$ Maritain writes that God, the first cause, is its 'supreme analogate', which means that He is Beauty itself, in which the beauty of created things dimly participates insofar as each thing can.

\footnotetext{
${ }^{77}$ Art and Scholasticism p. 48.

${ }^{78}$ Ibid. p. 58

${ }^{79}$ Creative Intuition p. 161.

${ }^{80}$ Ibid.
} 
God's pure intellection perceives transcendental beauty, that is, the beauty of being, and all that exists is beautiful to Him. We, on the other hand, perceiving through our senses, perceive what Maritain calls 'aesthetic beauty', that is, transcendental beauty perceived through the combination of sense and intellect, 'intelligence-permeated sense', employed by man. ${ }^{82}$

This is the nature of the beauty that Maritain writes is the essence of the artwork, which is brought into being because of the intellect's desire for a work in which it delights. He writes, 'The creator in art is he who discovers a new typeanalogy of the beautiful, a new way in which the brilliance of form can be made to shine upon matter, ${ }^{83}$ A new type-analogy of the beautiful is a new way for a thing to be beautiful in its own way, whilst remaining a participation in the ultrabeautiful Beauty of God. This is done by creating a new form, the art-work. The faculty of art is thus profoundly related to God's creativity. Maritain writes that it is 'the faculty of producing, not of course ex nihilo, but out of a pre-existing matter, a new creature, an original being, ${ }^{84}$ The artist as he bestows a new form upon matter, is imitating and continuing the activity of God. A further principle derives from this, in Maritain's thought, that in order to create a new form, the artist must be profoundly aware of the forms in nature, which is a kind of awareness of God, who brought them into being. Nature is the divine art-work, and the artist learns the principle of forming in beauty through it from God.

\footnotetext{
${ }^{81}$ Maritain's position on the question of whether beauty is a transcendental, to which I referred in the previous chapter, is that it is 'the splendour of all the transcendentals together' (Art and Scholasticism pp. 172-173).

${ }^{82}$ Creative Intuition p. 164.

${ }^{83}$ Art and Scholasticism p. 46.

${ }^{84}$ Ibid. p. 63.
} 
Maritain writes that 'whether he knows it or not, [the artist] is consulting God when he looks at things'. 85

Maritain addresses the question of the relation between an artist's perception of the divine beauty in the forms of nature and the beauty of the new form of the art-work with the notion of creative intuition. Following Aristotle, he discerns a function of the reason that does not simply connect and infer but which sees, or grasps first principles. He calls this the 'intuitive reason', and asserts that it is the primary act of the intellect. It is at work even in speculative knowledge, for 'any discovery which really reveals a new aspect of being is born in a flash of intuitivity before being discursively tested and justified, ${ }^{86}$ In the making of a work of art the part played by the intuitive reason is predominant, and from it the non-conceptual quality of art derives. This primary activity of the intellect occurs in an area of the mind Maritain calls the 'spiritual unconscious'. This is not related to the Freudian unconscious, which is an entirely material entity. Both are at work at the same time, according to Maritain, and the former does not operate without the interference of the latter except in rare instances. Nevertheless they are different in nature. The existence of a spiritual unconscious, according to Maritain, can be deduced from reflection on the normal way in which ideas arise in the mind or in which decisions come to be made. He writes, 'The universe of concepts, logical connections... and rational deliberation... is preceded by the hidden workings of an immense and primal preconscious life' ${ }^{87}$ Beneath the clarity of conscious concepts and judgements lie the non-rational sources of knowledge, love and creativity from which those conscious mental activities take shape. Although we know what we are thinking, we do not know how we are

\footnotetext{
${ }^{85}$ Ibid. p. 64.

${ }^{86}$ Ibid. p. 76.
} 
thinking it. Maritain calls this preconscious mental activity the spiritual unconscious.

He argues that in the spiritual unconscious all the soul's faculties are loosely engaged in common. Here Maritain locates the source of artistic and literary creation, which he describes as a certain free activity of the intellect, which is neither engaged in the production of concepts or decisions nor bound by the necessity of conforming to objective reality. This activity is a kind of knowledge, but, being preconscious, it is engaged in by all the powers of the soul together, and is thus not conceptual knowledge but intuitive knowledge. It simply grasps rather than discursively knowing its object. Maritain calls it 'poetic intuition', because it is an intuitive knowledge that tends to formation. It does not tend towards the production of a concept but towards the production of a work. Because it is a 'free' activity, not bound by the laws of objectivity, it tends towards the freedom of the work of fine art from a particular end. ${ }^{88}$ It is a kind of knowledge, in short, that is not formed by an object but is formative of one.

It is thus an analogy of the 'creative Idea' of God, which, for Maritain, is an essentially formative intellectual act. He writes that God's creation through an intellection which is His essence is the 'supreme analogate' of poetry. ${ }^{89} \mathrm{He}$ continues that in the poet's creativity, as in God's, this intellective act manifests in the work produced the subjectivity of the creator. A person's subjectivity, in the 'deepest ontological sense' that Maritain has in mind, is inconceptualisable, since so much of it is unconscious. ${ }^{90}$ A person does not know his own essence, but perceives himself only through knowledge of the world of things and

\footnotetext{
${ }^{87}$ Ibid. p. 94.

${ }^{88}$ Ibid. pp. $108 \mathrm{ff}$.

${ }^{89}$ Ibid. p. 112.

${ }^{90}$ Ibid. p. 113.
} 
reflection on his acts therein. The poet's obscure grasping of his subjectivity occurs through his intuitive grasp of things. Maritain calls this simultaneous knowledge of self and things 'poetic knowledge'. He writes that in the poet, 'at a single wakening, [things] and he come forth together out of sleep'. ${ }^{91}$ Poetic intuition is 'an obscure grasping of his own self and of things in a knowledge through union or through connaturality which is born in the spiritual unconscious'. ${ }^{92}$

Maritain is thinking of a kind of non-conceptual and preconscious knowledge of a thing and of oneself, in which the thing is not perceived as something other than the self, as in conscious and speculative knowledge, but as identified with oneself. This is what he means by knowledge through connaturality or affective union. Connaturality is the Scholastic concept according to which one makes a judgement pertaining to a moral virtue insofar as one possesses that virtue. Knowing nothing about chastity, I may nevertheless be a chaste man, and therefore act chastely in a given situation. ${ }^{93}$ This is called judgement by connaturality, because when a person has acquired a virtue as a habit, it becomes a part of his or her nature. The knowledge on which such judgements are based is not rational or conceptual knowledge, but it is, Maritain writes, 'really and genuinely knowledge, though obscure and perhaps incapable of giving account of itself ${ }^{94}$ He calls it knowledge through 'affective connaturality', by which he means that the poet's subjectivity and the objects he or she perceives are united

\footnotetext{
${ }^{91}$ Ibid. p. 114.

92 Ibid. p. 115.

${ }^{93}$ See Summa Theologiae Ia 1, 6 ad 3 and IIa-IIae, 45, 2.

${ }^{94}$ Ibid. p. 117. In Art and Prudence: Studies in the Thought of Jacques Maritain (Notre Dame: University of Notre Dame Press, 1988) chs. 10-11, Ralph McInerney argues that Aquinas' thought prevents one speaking of creative intuition as an instance of judgement by affective connaturality. He describes Maritain's use of the notion as 'creative Thomism' (ibid. p.158).
} 
by means of emotion. ${ }^{95}$ The kind of emotion Maritain has in mind is raised to the level of the intellect, and performs for the intellect the function otherwise fulfilled by the concept, that of the instrument through which reality is grasped. In poetic intuition, one as it were suffers reality more than one knows it, experiencing things through their affect on oneself rather than knowing them as objects external to oneself. Maritain writes, 'Poetic intuition is directed toward concrete existence as connatural to the soul pierced by a given emotion ${ }^{96}$ It grasps the 'total unicity' of a moment in time, in which oneself and a thing are known inseparably, in a non-conceptual knowledge through the connaturality of the affected soul and the affecting thing. ${ }^{97}$

Maritain writes that poetic intuition can be considered with respect to its cognitive function and with respect to its creative function. In terms of its cognitive function, he writes that it grasps an existent thing at the same time as 'all the other realities which echo in this existent, and which it conveys in the manner of a sign'. ${ }^{98}$ It obscurely divines the infinite amount of reality engaged in any given thing, the hidden properties of its being and all the beings to which it is related. This is because 'things are not only what they are', for Maritain, but stand in an infinity of relations or 'communication' with one another. ${ }^{99}$ The cognitive aspect of poetic intuition with respect to the thing grasped is this ontological participation in an infinite network of relations and sympathies. Its creative aspect is that it has as its goal not knowledge but creation. Maritain writes that poetic intuition is 'an incitation to create'. ${ }^{100}$ It tends of its essence

\footnotetext{
${ }^{95}$ Ibid. p. 118.

${ }_{97}^{95}$ Ibid. p. 126.

${ }^{97}$ lbid.

${ }^{98}$ Ibid.

${ }^{99}$ Ibid. p. 127.

${ }^{100}$ Ibid. p. 134.
} 
towards operation. The work is the conscious expression of the poetic intuition, the end result towards which it tends, just as the concept or decision is the end of the activity of the intellect. ${ }^{101}$

Maritain focuses on the role of the author, but his theory of creative intuition also includes the role of the reader. He emphasises that a literary work is an end in itself, a 'new creature engendered in beauty', rather than a vehicle of communication. ${ }^{102}$ The element of communication in a work is accidental insofar as creative intuition is concerned, but it is crucial to the poet with respect to his or her humanity. With regard to the reader, Maritain writes, 'What the work tends finally to convey to the soul of others is the same poetic intuition which was in the soul of the poet'. ${ }^{103}$ The beauty of the work for the reader is the 'radiance of the ontologic mystery grasped by the intuition of the poet'. 104 Maritain calls the reader's a receptive, rather than a creative, intuition. He does not suggest that all receptions of a work are the same, and he writes that a poetic intuition is of its nature inexhaustible and larger than the work in which it is expressed. One reader, in one place and time, may perceive one aspect of it; another in different circumstances may perceive others. Maritain writes, 'It is our good fortune if the smallest bit of it is really conveyed to us, ${ }^{105}$ For Maritain, a reader's perception amounts to the reception of an 'intellectual gift', which is a participation in the mystery of things that the author intuited. ${ }^{106} \mathrm{He}$ discusses in

\footnotetext{
101 Ibid. p. 118.

102 Ibid. p. 306.

${ }^{103}$ Ibid. p. 307.

104 Ibid.

${ }^{105}$ Ibid. p. 308.

${ }^{106}$ Ibid. p. 309.
} 
some detail the rhetorical means by which the immediate signifieds of the work can lead back to this original intuition. ${ }^{107}$

What can we make of Maritain's Scholastic aesthetics today? Critics are divided on the significance of his thought for contemporary theory. Paul $\mathrm{J}$. Marcotte, in his article, "Maritain's Concepts of "Creative Intuition" and "The Spiritual Unconscious of the Soul"' (1981), asserts that Maritain's work would transform the state of critical theory, "if only those people who are responsible for... English studies were disposed to approach him... with an open mind' ${ }^{108} \mathrm{He}$ makes this assertion, however, in the context of a dismissal of post-structuralist thought, and so gives no indication how Maritain's ideas might be brought into dialogue with such thought. Neal Oxenhandler, in his article, 'Maritain and Recent Critical Thought' (1982), is more judicious, as he writes that whilst Maritain's presuppositions and language are no longer available to the contemporary critic, his ideas may well prove fruitful when literary theory has become dissatisfied with its present presuppositions. ${ }^{109}$ In the meantime one can maintain that 'those convictions that [one retains] from [Maritain] are...more important than the...language in which he expressed them'. ${ }^{110}$ This is a fair judgement. In my view, we could express those convictions as follows. We can accept Maritain's Scholastic understanding of art as the faculty of making or production in general. We can agree that literary production is a kind of labour, in which certain materials are transformed with respect to a certain end or ends. We can follow Maritain's assertion that beauty is an end of fictional production

\footnotetext{
${ }^{107}$ Ibid. pp. 310-333.

108 Paul J. Marcotte, 'Maritain's Concepts of 'The Creative Intuition' and 'The Spiritual Unconscious of the Soul': Their Importance to, and their Neglect by, Professors and Students of English Studies', Journal of Canadian Poetry 3 (1981) p. 31.

${ }^{109}$ Neal Oxenhandler. 'Maritain and Recent Critical Thought', Renascence: Essays on Value in Literature 34 (1982) pp. 260-270.
} 
insofar as he means by beauty that in which the intellect takes pleasure. Whilst there are moral and intellectual goods to reading, we can take from Maritain the principle that one of its goods is the pleasure which derives from the temporary freedom of the mind from intellectual or practical concerns. We cannot assert with him that beauty is the primary good of a work, however, since this would imply a lack of ethical concern with the context of its production and receptions, nor need we accept his prescriptions for the psychology of the artist that follow from it. With respect to his doctrine of the spiritual unconscious, whilst it is plausible, we need not commit ourselves to Maritain's Thomistic psychology in order to think of literary production in terms of Christian theology. We can take from the doctrine the principle that writing fictional texts can be a way in which an author comes to an increased understanding of the world of his or her existence, and makes himself or herself more at home there, but we have no reason to follow Maritain's assertion that literary production is stimulated by a connatural knowledge of things. We can abstract from his theory of connaturality, however, the principle that the knowledge that can be gained from reading fiction can be of a more integral kind than purely intellectual knowledge, and we can add that it is one of the specific goods of such reading. We can also derive a standard of value from Maritain's aesthetics, namely the degree to which a text enables a given reader or readers to recognise in it some aspect of their existence previously obscure or unknown to them. We can assert with Maritain that such increased knowledge of created existence is, however consciously, an increased knowledge of its creator.

${ }^{110}$ Ibid. p. 270. 


\section{Eric Gill}

Maritain's aesthetics are given a political context in the work of Eric Gill (1882-1940), artist and Dominican tertiary, who was influential in the distributist movement in England in the first half of the century. The distributists, influenced by the thought of Hilaire Belloc and G.K. Chesterton, attacked the dehumanisation brought about by monopoly capitalism and industrialism, and called for a return to small-scale agrarian industry. ${ }^{111}$ With printer Hilary Pepler, Gill founded the Guild of St. Joseph and St. Dominic at Ditchling, Sussex, in 1912, a community of craftsmen committed to hand-produced works, living under the rule of the Dominican third order. Gill was influenced by Maritain's aesthetics, and he published the first English translation of Art and Scholasticism, under the title 'The Philosophy of Art', at Ditchling in 1923.

Gill found in Thomist aesthetics a corrective for the abuses perpetrated by industrial society. In his essay 'Art and Industrialism' (1933), he writes, following Maritain, that 'art is deliberate skill used for the good of something to be made' ${ }^{112}$ It is the use of skill by a person with free will and thus responsible for the use he or she makes of it. An artist, therefore, Gill defines as a 'responsible workman'. ${ }^{113}$ He writes that the responsibility of the workman is to be 'concerned for the rightness and goodness of his work', that is, to make the work as it ought to be made. ${ }^{114}$ It will be beautiful insofar as it is good and true, that is, insofar as it is the thing it is supposed to be and as it fulfils the use for which it is made. Gill writes that art is tantamount to charity, since the making of

${ }^{111}$ R.P. Walsh. 'Distributism', The New Catholic Encyclopaedia (New York: McGraw-Hill, 1967) Vol. IV p. 912.

${ }^{112}$ Eric Gill, Beauty Looks After Herself (London: Sheed and Ward, 1933) p. 180.

${ }^{113}$ Ibid. p. 184. 
a thing as well as it can be made is done for no other reason (such as profit) than 'for the glory of God and the love of [one's] neighbour'. ${ }^{115} \mathrm{He}$ asserts that the artist has the dignity of human responsibility and of participation in the creative work of God. ${ }^{116}$

Until the Industrial Revolution, according to Gill, all workmen were artists. With the development of machinery for mass-production in factories, however, most workmen have ceased to be responsible for the goodness of works, since they neither conceive nor make them. Machines make products, and the workman simply operates or minds the machines. Gill writes:

The craftsman is finally degraded - he ceases to be a person who in any way designs what he makes...He is no longer even a hand: he has become... a sentient part of the machine. ${ }^{117}$

The owner of the factory is not concerned with making a product well, but only with making one that will sell. A factory hand's work demands only skilful obedience, or even obedience without skill. He is expected simply to do what he is told, which Gill calls 'slavery'. ${ }^{18}$ Under industrial capitalism, most workmen have thus ceased to become responsible for the good of the work they make. Gill calls this 'a subhuman condition of intellectual irresponsibility' ${ }^{119}$ While the designer of a car, for example, is an artist, the men who make it are simply his 'hands'. Insofar as they exercise no responsibility in their role in production, they are 'not men' but slaves or 'puppets'. ${ }^{120}$ The result of industrialism, Gill writes, has thus been not only to concentrate wealth and power in the hands of the few but also 'to concentrate intellectual responsibility in the minds of the

\footnotetext{
${ }^{114}$ Eric Gill, Art Nonsense and Other Essays (London: Cassell and Co., 1929) p. 71.

${ }^{115}$ Eric Gill. Christianity and the Machine Age (London: The Sheldon Press, 1940) p. 27

${ }^{116}$ Beauty Looks after Herself pp. 246-253.

${ }^{117}$ Christianity and the Machine Age p. 39.

${ }_{118}^{118}$ Art Nonsense p. 132.

${ }^{119}$ Ibid.

${ }^{120}$ Beauty Looks After Herself p. 188.
} 
few' ${ }^{121}$ The mass of the population is dependent not only for its wages but also for its opinions on the owners of industry, who supply what it is profitable for them to supply, namely 'trash for books and lies for news'. ${ }^{122}$ Gill writes that 'no slavery has been so absolute as that of our own time', since it is intellectual as well as economic. $^{123}$

The intellectual standard of industrialist culture thus becomes very low. In Thomistic psychology, the intellect and the will are trained and strengthened in respect of their objects, the true and the good, as they are used. Gill writes, 'We are all trained by what we do'. ${ }^{124}$ In his essay 'Art and the People' (1932), he asserts that since the responsible use of the will and a concern for the good are a not part of industrial working life, it is only to be expected that they will not be a part of a workman's leisure time either. Since art is not required of most at work, it comes to be seen as the province of a few eccentrics, the 'fine' artists, who remain responsible for their works, although on the fringe of society. It can be appreciated in people's leisure time, but their work gives them no inclination for such appreciation. Gill writes, 'It is absurd to foist high aesthetics on people whose working life does not develop in them any intellectual responsibility'. ${ }^{125}$ He argues that beauty, the end of fine art, is apprehended by the intellect and the will together. Because these powers are not demanded in industrial working life, they decline and there is little inclination to use them in leisure time. Gill writes that, as a result, a work of beauty ceases to attract, since the less the intelligence seeks truth and the will seeks goodness, the less beauty will please both. The workman seeks entertainment rather than art in his spare time, which, whilst it

\footnotetext{
121 Ibid. p. 201.

122 lbid. p. 202.

123 Ibid. p. 144.

${ }^{124}$ Ibid.
} 
can be good in its kind, lacks the sanctifying power Gill discerns in the latter, which puts the mind in touch with a transcendental and so with its divine analogate.

Whilst we need not commit ourselves to Gill's Thomistic metaphysical framework, we can nevertheless accept some of his aesthetic principles. We need not follow his view that workmen primarily pursued the good of their work before the Industrial Revolution, but we can accept the principle that the working conditions of industrial and technological capitalism discourage the majority of people from the valuable experience of increased knowledge in reading fiction. We can follow Gill in asserting that whilst this experience is not that of the majority of readers, this is not an index of the conservatism of the idea but a result of the conditions in which it is profitable for them to work in a capitalist economy

\section{David Jones}

An anthropological version of neo-Thomist literary theory can be found in the work of Gill's friend David Jones (1895-1974), poet, painter, engraver and sometime member of the Ditchling Guild. In his essay 'Art and Sacrament' (1955), Jones addresses the relation between art and Catholicism, to which he had converted in 1921 . He writes that man is by definition an artist, 'a prudential animal whose nature is to practise an intransitive activity to which adheres a gratuitous quality'. ${ }^{126}$ By the term 'prudential animal', he means that human beings are alone among primates in acting according to various doctrinal and

\footnotetext{
${ }^{125}$ Ibid. p. 149.

${ }^{126}$ David Jones, Epoch and Artist (London: Faber and Faber, 1959), p. 154.
} 
moral codes. This presupposes a freedom of action, which can be considered man's distinctive characteristic in the animal kingdom. This freedom also distinguishes his art from all other animal making, since he is alone in making works as the result of a free choice rather than by instinct. Jones finds this anthropology corroborated by zoology's classification of man as sapiens, or 'wise', as well by Thomistic psychology.

Jones writes that a further distinguishing mark of man's art is that the works we produce have the character of signs. He writes, 'For about fifty milleniums, [man has]...handled material in a fashion that can only be described as having the nature of a sign ${ }^{\prime 127}$ Not only the paintings at Lascaux but the most primitive markings on ancient stones indicate that man has always been a sign-making animal. The nature of these signs Jones calls 'sacramental', because, like sacraments, their purpose is the recalling or re-presentation of something sacred. He writes, 'On account of this anthropic sign-making...we first suspect that anthropos has some part in a without-endness' ${ }^{128}$ The nature of the man-made sign, Jones writes, has something sacred about it. Since, in Thomistic metaphysics the good is conceived of as a transcendental, then a sign that signifies something that exists also signifies something good. A thing's being and goodness are analogous to the being and goodness of God. Insofar as these qualities are comported by a sign, Jones writes, "the notion of sign implies the sacred'. ${ }^{129}$ He continues, following Maritain, that art is a religious activity, that is, it binds man to God, insofar as the artist participates in the divine act of

\footnotetext{
${ }^{127}$ Ibid. p. 155.

${ }^{128}$ Ibid. p. 156.

${ }^{129}$ Ibid. p. 157.
} 
bringing into being a new form. ${ }^{130}$ The new form, Jones adds, is a sign of God's creative activity.

Jones addresses the question of the relation between the sacramental character of art-works and the sacraments of the church. From its earliest days, he writes, the Church has 'demanded as a condition of membership the acceptance of a belief involving certain of the arts ${ }^{3}{ }^{131}$ The material signs that are the church's sacraments have always been regarded as integral to Christian belief, because Christ himself commanded that they should be used. Regardless of differences of theology, almost all Christians believe to one degree or another that at the Last Supper Christ initiated a sign that he meant to be repeated. Whether at a Protestant Breaking of Bread or at a Catholic High Mass, Jones writes, 'you would... witness... an art-work' ${ }^{132}$ Something, that is, is shown forth or recalled by means of a sign. Christ said 'Do this for an anamnesis of me'. This anamnesis, or recalling to mind, is the essence both of art and of sacrament, for Jones. Indeed, he writes, Christianity is 'committed to Ars in the most explicit, compelling and integral manner', because the crucifixion of Christ, its central article of faith, is also a sign. ${ }^{133}$ Jones writes that it 'presupposes the sign-world and looks back to foreshadowing rites... stretching back for tens of thousands of years'. ${ }^{134}$ He means that Christ's crucifixion takes on its meaning in various semiotic codes, such as the pagan rites of death and resurrection, and the Christian theology of man's fall and redemption. Whatever the denominational theology of the relation of the crucifixion to the Eucharist, Jones writes, the latter is held to recall or to show forth the former in an 'unbloody' manner, which is to

\footnotetext{
${ }^{130}$ lbid. p. 158.

131 Ibid. p. 162.

${ }^{132}$ Ibid. p. 163.

${ }^{139}$ Ibid. p. 167.
} 
say that it represents the crucifixion in an artistic fashion. ${ }^{135}$ Jones writes, 'All art re-presents', that is, it is a sign of a certain reality that the work makes present again. ${ }^{136}$ This reality is 'too complicated to posit with any precision', he writes, but it is present in the sign of the work. Whatever the complex inter-relation of external objects and psychological states that are the causes of a work of art, the work is 'a signum of that reality, under the species of [for example] paint'. ${ }^{137}$ The eucharist is a sacramental sign in the way that all art-works are, according to Jones, in that both recall some kind of sacred reality too complex to be known by the intellect alone.

Jones' essay is a series of suggestions rather than a sustained argument, but there are certain principles we can accept from it nevertheless. We can follow his comparison of a literary text to a sacrament in the sense that the latter is a sign of a divine reality, although in no other sense. Insofar as the experience of reading a fictional text can provide a reader with increased knowledge of created worid of his or her existence, we can assert that it can provide him or her with an increased knowledge, however small, of its creator. In this sense we can agree with Jones that the literary text is analogous to a sacrament, since it can function as a sign of a reality whose ground is the relation of the world to God.

\footnotetext{
${ }^{134}$ Ibid. p. 168.

${ }^{135}$ Ibid. p. 171.

${ }^{136}$ Ibid. p. 173.

${ }^{137}$ Ibid. p. 175.
} 


\section{(iii) Religion and Literature}

Neo-Thomism began as a philosophical movement, and its has remained current primarily in philosophical rather than in literary-critical circles. I will conclude this chapter with an examination of some of the ways in which literary critics have attempted to understand their field in terms of Christian theology, and I will assess the degree to which these attempts can be pursued in Christian literary theory today.

\section{T.S. Eliot and the New Criticism}

A seminal essay in modern Christian criticism is T.S. Eliot's 'Religion and Literature' (1935). This work advocated a method of criticism whose criteria were derived from Christian doctrine. Eliot's thesis in the essay is that 'literary criticism should be completed by criticism from a definite ethical and theological standpoint'. ${ }^{138}$ He writes that literary criticism is effective in society insofar as there is a common world-view from which the standards implied by criticism derive. Given that Christianity plays a negligible role in the spirit of the age, it is particularly necessary for Christian readers consciously to use Christian standards of judgement rather than a kind of bricolage of principles derived, though it may not be immediately apparent, from world-views incompatible with their own. Christian criticism, Eliot stresses, is not concerned primarily with 'religious literature', that is with the literary qualities of religious texts, with devotional literature or with propagandist literature, but with 'the application of

\footnotetext{
${ }^{138}$ Selected Prose of T.S. Eliot, ed. Frank Kermode (New York: Harcourt Brace Janovich, 1975) p. 97.
} 
our religion to the criticism of any literature' ${ }^{139}$ This is particularly important, in Eliot's view, with regard to modern literature, since it is written largely by people without a belief in the supernatural, and who, on the whole, regard such a belief as an antiquated relic of a bygone age.

There are several principles in this essay which we need no longer accept. We cannot follow Eliot's distinction between a work's 'greatness', which is to be determined by ethical and theological standards, and 'whether it is literature', which is to be determined by literary standards, since there are no criteria of critical judgement that are not already ethical and theological, in the sense that they derive from moral and intellectual first principles. In an essay entitled 'Criticism and Theological Standards' (1959), Vincent Buckley points out that 'an ethical and theological criticism of literature which completes literary criticism is very difficult to conceive, and...the people who have attempted it... have fallen into the pit of divided attention' ${ }^{140}$ Nor need we share Eliot's sense of urgency at the secular beliefs expressed in modern literature, since secularism is on the whole axiomatic in the post-modern age. Nevertheless, we can accept from him the principle that Christian criticism will consist in the interpretation of literary works in terms of the faith of the Christian community. We can follow him further in asserting that, since all discourse implies some system of beliefs about the world, one task of such criticism, where appropriate, might be an engagement in dialogue with these beliefs that the critic finds expressed in the text.

A critic of Eliot's generation who pursued his concept of Christian criticism was Dorothy Sayers (1893-1957). In her essay 'Towards a Christian Aesthetic'

${ }^{139}$ Ibid. p. 98. 
(1944), she notes that whilst the church has articulated no systematic thought on the arts, nevertheless 'if we commit ourselves to saying that the Christian revelation discovers to us the nature of all truth, then it must discover to us the nature of the truth about art'. ${ }^{141}$ She sets out to derive a Christian aesthetic from a theology of creation, which she calls 'the one important contribution that Christianity has made to aesthetics'. ${ }^{142}$ In the Christian theology of creation, the First Person of the Trinity creates the world through the Second, who is His consubstantial image, and through whom He is known. Sayers paraphrases: 'The Unimaginable and the Image are one and the same'. ${ }^{143}$ She argues that the same relation inheres between the experience of which a literary work is the expression and its expression in the work. She writes, 'The poet did not know what his experience was until he created the poem which revealed his own experience to himself ${ }^{144}$ The poem and the experience are one, that is, just as the Son and the Father are one. Sayers argues that the mediating factor between the work and the experience is that of recognition, insofar as the work reveals the experience that was unknowable without it. She writes that there are thus three elements in one indivisible act of literary creation, in an analogous relation to the three hypostases in the one substance of the divine creator. Furthermore, in order to communicate with a reader, Sayers writes, the author incarnates the expression of his experience in a material form, and in this material image the reader may recognise the image of some hitherto inexpressible experience of his own. This process Sayers likens to the Incarnation, insofar as 'the third person of

\footnotetext{
${ }_{140}$ Nathan A. Scott, Jr., ed., The New Orpheus: Essays Towards A Christian Poetic (New York: Sheed and Ward. 1964) p. 181.

${ }^{141}$ Ibid. p. 4.

${ }^{142}$ Ibid. p. 13.

143 Ibid p. 14.

144 lbid.
} 
the poet's trinity brings us, through the incarnate image, into direct knowledge of the in itself unknowable and unimaginable reality'. ${ }^{145}$

We cannot accept Sayers' first principle that the literary work perfectly embodies the meaning of an experience which could not otherwise be expressed without implying that it is impervious to the kind of rational analysis which is a precondition of ethical criticism. Nevertheless, we can follow her argument that the recognition of previously inexpressible experience in reading is one principle by which the value of a work to a reader can be judged. It is a relatively uncommon experience, she writes, and not what most people experience when they read. Most people do so simply for the sake of entertainment, for which they need the kind of art that 'does not reveal us to ourselves, [but] merely projects onto a mental screen a picture of ourselves as we already fancy ourselves to be - only bigger and brighter'. ${ }^{46}$ Sayers calls this 'pseudo-art', and writes that it is to genuinely creative art 'as the idol is to the image'. ${ }^{147}$ We can follow Sayers in asserting that the recognition in a text of some aspect of existence previously obscure to a given reader is one index of its value to that reader. We can follow her further in understanding the experience of wishfulfilment, as opposed to that of increased knowledge, in reading a text as a negative index of its value

The final voice in what we could call the first generation of modern Christian criticism was that of the New Critics. Although they avoided the use of theology in criticism, many of them were Christians, and they occasionally reflected on the relation of their faith to their critical practice. In the epilogue to Literary Criticism: A Short History (1957), William K. Wimsatt and Cleanth Brooks 
write that they 'have not been concerned to implicate literary theory with any kind of religious doctrine'. ${ }^{148}$ Nevertheless, their history has led them to the conclusion that the most plausible context for literary theory is neither idealism nor dualism, but 'the vision of suffering, the optimism, the mystery which are embraced in the religious dogma of the Incarnation'. ${ }^{149}$ They argue that poetry, which they see as a conflict of opposing meanings held together in tension, is representative of the ethical conflict of Christian life. They write, 'The theatre of poetic conflict is human substance itself...the conflict is of man with himself or of good and evil in man'. ${ }^{150}$ In 'Horses of Wrath' (1962), Wimsatt writes that facing up to the conflict between flesh and spirit or good and evil is, in a Christian world-view, 'a desirable and mature state of soul', and also 'the right model and course of a mature poetic art'. ${ }^{151}$ Although the conflict is not in itself valuable, according to Wimsatt, it nevertheless constitutes the nature of moral life. The art that embodies this conflict, therefore, with 'the concreteness of recognition and inclusion', is the most genuinely representative kind of art. ${ }^{152}$

In his essay 'Poetry and Christian Thinking' (1951), Wimsatt remains undecided as to the theological value of poetry as discordia concors, although he hints that it may have an existential superiority to more abstract doctrinal formulations. ${ }^{153} \mathrm{He}$ also avoids judgement on the question of the revelatory quality of literary form in Scriptural and theological texts, although he insists

\footnotetext{
${ }^{147}$ Ibid. p. 19.

${ }^{148}$ William K. Wimsatt, Jr. and Cleanth Brooks, Literary Criticism: A Short History (London: Routledge and Kegan Paul, 1957) p. 746.

${ }_{149}^{14}$ Ibid.

150 Ibid. p. 745.

151 William K. Wimsatt, Jr., Hateful Contraries: Studies in Literature and Criticism (Lexington: University of Kentucky Press, 1965) p. 32

${ }_{153}$ Ibid.

${ }^{153}$ William K. Wimsatt, Jr. and Monroe C. Beardsley, The Verbal Icon: Studies in the Meaning of Poetry (Lexington: University of Kentucky Press, 1954) pp. 274-275.
} 
that the question is an important one. ${ }^{154}$ In his essay 'Religion and Literature' (1974), Cleanth Brooks argues that the commitment demanded by religion renders it functionally distinct from literature. Only if the two are seen as clearly different, he writes, in contrast to the thought of Matthew Arnold and Ralph Waldo Emerson, can literature play its genuinely moral role. It can function as a criticism of a given social situation, for Brooks, but it cannot remedy the situation it criticises. That is the function of religion, and if literary works are elevated to the position of religious texts, neither will play their proper roles in society. ${ }^{155}$

We need not accept the characteristic New Critical principle that criticism should be concerned only with the formal qualities of texts, but we can nevertheless use some of these reflections on literature and religion in Christian theory today. We can follow Wimsatt in asserting that the contradictory forces of meaning which can be discerned in fictional texts can in part be determined by the internal conflicts of human desire explained by the Christian theology of the fall. Where appropriate, Christian criticism might interpret such contradictions in the terms of this theology. We can follow Brooks in asserting that one of the goods of fiction is its potential for ethical critique of the social situation of its production and of its receptions. We can take it as one task of Christian criticism to describe, where appropriate, the ethical function of a text in a given historical situation.

${ }^{154}$ Ibid. pp. 276-279. 


\section{Nathan Scott and Existential Theology}

In the 1950s, several American universities began to offer courses in Religion and Literature. These courses were run by theologians and critics such as Preston Roberts at Chicago, Stanley Hopper at Syracuse and Amos N. Wilder at Harvard. Most influential among them was Nathan A. Scott, Jr. (b. 1925), of Howard University (1948-1955), Chicago Divinity School (1955-1977) and the University of Virginia, where he is Professor Emeritus in Religious Studies and English. ${ }^{156}$ Scott found in the theology of culture of Paul Tillich (1886-1965) the rationale for a Christian study of contemporary literature. Tillich argued that the religious situation of ultimate concern was expressed in literary texts and other cultural phenomena. In his book Negative Capability (1969), Scott writes, 'The Christian enterprise, as it seeks to make contact with the living reality of its human environment, may find in literary art a most helpful resource'. ${ }^{157}$ The study of the literary forms and concerns of an age can function, Scott argues, as an index of the spirit of the age to which the Christian message is to be addressed.

Scott argued against the formalist isolation of the text from the beliefs, values and commitments that were a part of the situation in which it was produced. In his article 'The Relation of Theology to Literary Criticism' (1953), he writes that 'to accord such autonomy to the mode of existence of a poem or a novel is... to

${ }^{155}$ Cleanth Brooks, 'Religion and Literature', Sewanee Review LXXXII (1974) pp. 93-95, 103106.

${ }^{156}$ See Anthony C. Yu, 'Nathan A. Scott, Jr., An Appreciation', in Morphologies of Faith: Essays in Religion and Culture in Honour of Nathan A. Scott. Jr., ed. Mary Gerhart and Anthony C. Yu (Atlanta: Scholars Press, 1990).

${ }^{157}$ Nathan A. Scott, Jr., Negative Capability: Studies in the New Literature and the Religious Situation (New Haven: Yale University Press, 1969) p. 163. 
assume that it was produced by an agent not fully human'. ${ }^{158}$ A person's creativity cannot be distinguished from his or her social, philosophical and religious attitudes, for Scott. He argues that in practice criticism always involves a judgement on a writer's insight into the human condition against the standard of the critic's own insights. Those who think themselves neutral or disinterested are in fact swayed by the beliefs they have acquired by being members of a given society at a given time and place. Since moral and doctrinal neutrality is out of the question, Scott writes, 'a theological criticism of the arts...is... a legitimate and necessary enterprise of the Christian intelligence' ${ }^{159} \mathrm{He}$ argues that this should constitute the kind of 'theonomous analysis of culture' described by Tillich in The Protestant Era (1951). Such analysis is based on the principle that 'the law of life transcends man, although it is, at the same time, his own'. ${ }^{60}$ Man is neither the bearer of universal reason nor to be subjected to a law external to him, for the divine law is also his own innermost law. This means that, as Tillich writes, 'in the depth of every autonomous culture, an ultimate concern, something unconditional and holy, is implied' "16i Tillich describes cultural analyses that pertain only to man as 'autonomous', and those which impose heterogeneous laws upon cultural objects as 'heteronomous', 162 A 'theonomous' analysis, he writes, is one which finds the hidden religious significance of cultural forms, since it is based on the belief that the divine law is their ground. It finds that in all of them there is an ultimate, unconditional and all-determining concern, something absolutely serious and therefore holy, even if

\footnotetext{
${ }^{158}$ Nathan A. Scott. Jr., 'The Relation of Theology to Literary Criticism', Journal of Religion XXXIII (1953) p. 268.

159 Ibid. p. 276.

${ }^{160}$ Paul Tillich. The Protestant Era, tr. James Luther Adams (London: Nisbet, 1951) p. 63.

${ }^{161}$ Ibid. p. 64.

${ }^{162}$ Ibid. p 65.
} 
expressed in secular terms'. ${ }^{163}$ It is by this 'way of theonomy' that Scott asserts that Christian criticism should proceed. ${ }^{164}$ As he puts it in "Theology and the Literary Imagination' (1968), the word of God can be heard 'not only in the scripture...but also in all those intellectual and cultural forms which... arise... out of man's deep encounter with his world and his own humanity'. ${ }^{65}$

In his article 'Prolegomenon to a Christian Poetic' (1955), Scott uses Martin Buber's distinction between an I-It and an I-Thou relationship as a criterion for Christian criticism. In Buber's thought, an individual becomes truly a person only in the meeting with a Thou, in which he no longer uses or exploits things for his own purposes but enters into a vital relationship with them. One can enter into an I-Thou relationship with anything, and in Buber's thought the universe invites such relationship. Scott calls this understanding of life 'proximately Christian', and a 'truly sacramental conception of life'. ${ }^{166}$ Christian criticism, he writes, should be concerned with a text as an expression of an author's contemplation of the created world in an I-Thou relationship. ${ }^{167}$ Scott calls this the 'vocation' of the poet, 'to stare, to look at the created world, and to lure the rest of us into a similar act of contemplation'. ${ }^{168}$ In The Wild Prayer of Longing (1971) he calls this the 'sacramental vision', which sees in the ordinary objects and actions of life 'something "numinous"... something holy and gracious", 169 Such a vision, in Scott's view, involves an existential acceptance of finitude, a source for which he finds in existentialist theology, in which '[serenity] in the

\footnotetext{
${ }^{163} \mathrm{Ibid}$.

${ }^{164}$ Scott, 'The Relation of Theology to Literary Criticism' p. 276.

165 Nathan A. Scott, Jr., ed., Adversity and Grace: Studies in Recent American Literature (Chicago: University of Chicago Press, 1968) p. 4.

${ }^{166}$ Nathan A. Scott. Jr., 'Prolegomenon to a Christian Poetic', Journal of Religion XXXV (1955)

p. 194.

67 Ibid. p. 195.

${ }^{168}$ Ibid.
} 
presence of the finite is rooted in a sense of participation in the ultimate power of Being'. In this theological tradition, Scott writes, the experience of finitude is overcome by courage rather than by a process of inference. According to Tillich, distress at one's finitude contains in itself an obscure awareness of the infinity of Being for which such distress is a desire. By accepting this principle, Scott writes, the Christian critic can find of the contemporary author that 'in the very depth of his ontological confusion there is expressed a sense of the ultimate meaning of existence upon the basis of which he still lives'. ${ }^{170}$

Scott's critical concerns were shared by the poet, minister and scholar Amos N. Wilder (1895-1993), who taught at Chicago Theological Seminary (19431954) and then at Harvard Divinity School (1954-1963), where he remained Professor Emeritus until his death. In his essay 'Art and Theological Meaning' (1962), he writes that in modern society the holy cannot be considered to transcend the world of human experience, but is only accessible through that world. Borrowing a phrase from Jean Cocteau, he calls this the 'secular mystery'. Wilder writes, 'If we are to have any transcendence today, even Christian, it must be in and through the secular'. ${ }^{171}$ Art is important for this view because it deals with the concrete realities of existence where transcendence is to be found. Wilder writes 'The believer and the artist are dealing with the same single reality'. ${ }^{172} \mathrm{He}$ writes that art can correct theology where it tends to abstract formulations, and remind it of the thereness of the world though which the holy is to be experienced. Citing Romans 10:19, 'With a foolish nation I will make you angry', Wilder defends the possibility that 'God is using the

\footnotetext{
${ }^{169}$ Nathan A. Scott. Jr., The Wild Prayer of Longing: Poetry and the Sacred (New Haven and London: Yale University Press. 1971) p. 49.

${ }^{170}$ Ibid. p. 205.

${ }^{171}$ Scott, The New Orpheus p. 407.
} 
essentially pagan reality of art...to provoke the Church,...to introduce a ferment into it. ${ }^{3}{ }^{173}$

We need not commit ourselves to Tillich's view that the contents of Christian faith are to be explained as theological answers to existential questions in order to accept some of the insights of his literary-critical disciples. ${ }^{174}$ We can follow Scott in asserting that the situation of ultimate concern in which religious beliefs are formed can aiso be found expressed in fictional texts. We can understand the writing of such a text as a means of negotiating this situation. We can accept from Scott the principle that one task of Christian criticism might be to describe its expression in a text, and to analyse the relations between the author's and the Christian responses to it. We need not follow Scott's assertion that there is a connection between literary production and the perception of a transcendent quality in the world of human existence, but we can accept that such perception is a possibility of the experience of reading. We can take it as a task of Christian criticism to describe the ways in which the critic judges that the immanence of God in the world is expressed in the text. We need not follow Wilder's assertion that in modern society God can only be known through secular cultural forms, but we can accept from him the principle that fictional texts can function as a critique of the faith and practice of the Christian community. Whilst such critique is primarily ethical, we can accept Wilder's view that it may also constitute a reminder to the church of the goodness and value of the world, which Christian thought should not efface in its emphasis on God's transcendence.

\footnotetext{
${ }^{172}$ Ibid. p. 408.

${ }^{173}$ Ibid. p. 413.
} 


\section{Contemporary Christian Theories}

The study of literature and religion has been widely promoted in Britain by David Jasper (b. 1951), of the universities of Durham (1979-1991) and Glasgow, where he is director of the Centre for the Study of Literature, Theology and the Arts. In The Study of Literature and Religion (1989), Jasper defends the 'irreducible importance' of engaged theology for Christian criticism, rather than a 'trivial notion of 'religion'... [derived] from literary standards claiming to be the arbiters of what constitutes true knowledge'. ${ }^{175} \mathrm{He}$ looks for a dialectical relationship of theology with contemporary literary theory, in which both will grow through the mutual encounter, and he sketches a series of ways in which that relationship might progress. Most significant of these, in Jasper's thought, is the encounter of theology with deconstruction. In 'The Study of Literature and Theology: Five Years On' (1992), he writes of the 'profound theological possibilities, through art, of the Derridean critique of ontology'. ${ }^{176} \mathrm{He}$ sees deconstruction as a 'radical purifying strategy' of discourse, of particular relevance to theodicy, the justification of God. If theology abandons the logocentrism by which it is conceived as a discourse with God as its sole given, in Jasper's view, a more valuable theodicy may arise. Deconstruction suggests that theodicy, which is, like all else, a text, should not begin its reflections at a pure starting-point, nor should it attempt to ascribe any kind of intention to God, since deconstruction shows that an author's intentions are not available from his work. A deconstructive theory of textuality, Jasper writes, can free theodicy from

\footnotetext{
${ }^{174}$ See Paul Tillich, Systematic Theology Vol. I (London: Nisbet. 1953) pp. 67.76.

${ }^{175}$ David Jasper, The Study of Literature and Religion: An Introduction (London: Macmillan, 1989) pp. $1,5$.
} 
the constraints of 'theological absolutism' into 'a new discernment of the mystery' of existence. ${ }^{177}$ Theodicy ceases to be a system demanding an impossible solution and becomes a textual enactment of the inexhaustible multiplicity of divine creation. It recognises that the solution to the theodical problem will be given in 'God's good time', but that here and now it is, like all propositions, in a process of deferral. ${ }^{178}$ The textuality of theodicy, Jasper writes, leads theology from a commitment to the closure of a text towards a commitment to the deferral of meaning. ${ }^{179}$ In this way, "beyond the fictions of...understanding', it can lead us to recognise something of the 'mystery of divine creativity'. ${ }^{180}$

We need not share Jasper's conviction that Derridean thought defers the ethical problem of theodicy, however much the latter is susceptible of deconstruction, since it seems to imply a quietism on the part of Christian ethics with respect to injustice. Nevertheless, we can follow Jasper in asserting that Christian literary theory will not constitute genuinely relevant contemporary discourses unless it has fully engaged with contemporary literary theory.

One of the most original examples of a Christian theory to have assimilated the insights of post-structuralism is Michael Edwards' Towards a Christian Poetics (1984). In this book, Edwards derives a literary theory from the Christian anthropology of Blaise Pascal (1623-1662). For Pascal, human grandeur, or 'greatness' - the goodness, truth and beauty of human life - derives from our

\footnotetext{
${ }^{176}$ David Jasper, 'The Study of Literature and Theology: Five Years On', Literature and Theology 6 (1992) p. 6.

${ }^{177}$ Ibid. p. 124.

${ }_{178}$ Ibid. p. 128.

179 Ibid. p. 130

${ }^{180}$ Ibid. p. 131.
} 
'first' created nature. ${ }^{181}$ Our misère, or 'wretchedness', derives from our 'second' concupiscent nature. A person is alienated from himself, for Pascal, in a double condition of greatness and wretchedness, in which to perceive one is also to perceive the other. These two principles are synthesised in Christ, who assumes all the grandeur and all the misery of humanity. Divine, and thus supremely great, by the excess of his wretchedness at the crucifixion, he initiates a new greatness, that of redeemed and glorified humanity. ${ }^{182}$ Edwards describes this as 'a ternary process, in which a positive is reversed by a negative, which is then reversed by a new positive far more powerful than the original'. This dialectic governs the Biblical view not only of man, in Edwards' view, but also of the world and its history. Biblical cosmology sees the universe progressing through the dialectic of creation, fall and re-creation. Biblical history charts the development from Eden through the fallen world to Paradise, and from Israel through its scattering to the Church. The fundamental process is life, death and resurrection, based on 'two instants of contradiction', the first between the greatness and wretchedness of the human world, and the second between their wretchedness and hints of a new splendour to come. Edwards writes that this dialectic can be understood to govern all experience. We live in the first contradiction, he argues, with glimpses and hints of the second. ${ }^{183}$

Edwards writes that language and literature progress through the same dialectic. He asserts that the grandeur of language consists in a correlation of names with things and their speaker, which he sees represented in the Biblical account of Adam's names. Its misère he finds in its ambiguity and lack of reference, represented by the Biblical account of the serpent's contradiction of

\footnotetext{
181 Blaise Pascal. Pensées 149, tr. A.J. Krailsheimer (London: Penguin, 1966) pp. 76-80.

${ }^{182}$ Michael Edwards. Towards A Christian Poetics (London: Macmillan, 1984) pp. 2-4.
} 
the divine economy with his words, 'You will not surely die'. ${ }^{184}$ After the Fall, Edwards argues, language remains characterised by both these elements. We have on the one hand a sense of language 'fulfilling our desires as speakers and writers', genuinely naming things and communicating our ideas to others. On the other hand, it seems that it is precisely language which prevents these things. This is the situation in which we find ourselves, Edwards asserts, between the second and the third stages of the Christian dialectic. In this dialectic, as the extremity of misere leads to a greater grandeur than the first, the very incongruity of language with the world furnishes us with hints of a new world. Edwards writes, 'Explored, language becomes a domain of suggestions, fragments of a novel reality emerging with fragments of a novel speech'. ${ }^{185}$ The fragmentary nature of language adumbrates 'no less than the renewal of reality', according to Edwards. ${ }^{186}$ As it bears the trace both of the creation and the Fall, so it bears the trace of the re-creation to which the two opposites dialectically lead.

Fictional texts, Edward argues, both articulate and enact the Christian dialectic. He writes that the latter can be traced in the genres of tragedy and comedy. Tragedy deals in greatness. Its hero is usually extremely great, 'the best of mortals', like Sophocles' Oedipus, or 'the foremost man of all this world', like Shakespeare's Julius Caesar. Edwards suggests that Adam is the 'shadowy presence' behind such figures, who often aspire to his role of government of the world, and who also take on his representative function. ${ }^{187}$ Tragedy is equally concerned with wretchedness. The extremely great hero is usually brought to an

\footnotetext{
${ }^{183}$ Ibid. p. 7.

${ }^{184}$ Ibid. p. 10

185 Ibid. p. 11

${ }^{186}$ Ibid. p. 12.
} 
extremely base action, often the murder of a family member. Edwards notes that the misery of the world after the tragic catastrophe is the misery of a fallen world, where suffering is not related to personal guilt, but is simply the way of the world. The catastrophe is analogous to the fall, Edwards writes. He notes that in the story of Oedipus, the dynamic of original sin, whereby the cause of one's unhappiness is ultimately oneself, is especially clear. Edwards writes, 'Tragedy is the confrontation... of these radical extremes of human existence', that is, the exceptional greatness and wretchedness of the hero and his family. ${ }^{188}$ The third term of the dialectic emerges in the worth of the dead hero, who, through the extremity of his misery, attains in the minds of the survivors a greatness that surpasses even his previous stature. Tragedy usually ends with a prophecy of the renewal of a dynasty or a society, often purified from the ills that previously beset it. When it does so, Edwards writes, 'it travels the whole dialectic', hinting that from the dual condition of man and the world a new creation of both shall emerge. $^{189}$

Whereas the plot of tragedy articulates the Christian dialectic, in Edwards' view, he finds narrative to be 'dialectical in itself' ${ }^{190}$ Whether or not Eden existed, in which being was undivided and the present was presence, it is clear that we are not there now. In such a state, Edwards writes, there would be no need for fiction, since the real would be fully satisfying. "We tell stories in a fallen world, he writes, meaning that the satisfying, meaningful and beautiful world of which we can conceive, but in which do not live, is projected into the narrated world of a story. Whether the narrated world appears more or less fallen

\footnotetext{
${ }^{187}$ Ibid. pp. 14-16.

188 Ibid. p. 21.

189 Tbid. p. 32.

${ }^{19 n}$ Ibid. p. 72 .
} 
than the one we inhabit daily, Edwards writes, it nevertheless represents a 'desirable otherness,' insofar as it at least has a story. ${ }^{191} \mathrm{He}$ asserts, 'We tell stories because we desire a world with a story'. ${ }^{192}$ A story's beginning provides the reader with a new beginning to a new world. Its end offers an indefinitely lasting future of hope, in a dimension of the story-world so secure that it does not need to be told. ${ }^{193}$ Edwards writes that fictional characters are transformed by the narrative in which they subsist. However amorphous, they live 'charmed lives', of guaranteed significance, in comparison to our own lives whose significance is merely desired. They inhabit what Edwards calls 'the glory of form'. He describes the activity of narration as 'the fiction of a fallen world remade'. 194

To what extent should we accept Edwards' theories as valid theses of Christian literary theory? We have no reason to dissent from his anthropological first principles, but it seems to me that his assertion that the dialectical structure that he extrapolates from them governs all aspects of human experience is too strong. There is no necessary relation between the polysemy and contradictory forces of meaning at work in a text, for example, and the resurrection and the new creation of the world. There are similarities between the two concepts, but no reason to believe that the former is a sign of the latter. In the same way, Edwards' reading of tragedy draws convincing parallels between the structure of the genre and that of the dialectic in which he casts Christian theology, but there is only a contingent relation between the content of the two discourses. Nevertheless, the reading serves as a good example of a critical principle I have advocated, that one of the tasks of Christian criticism might consist in bringing the world-view

\footnotetext{
191 Ibid. p. 73.

192 Ibid.

193 Ibid. p. 74.

${ }^{194}$ Ibid. pp. 75, 90.
} 
of the critic and that he or she discerns in the text into dialogue. We can accept from Edwards' theory of fiction the principle that one the pleasures of reading literary texts can be the experience of a world that is meaningful and secure in a way that the reader's own world is not. We can follow Edwards in asserting that the practice of producing and reading fiction is in part an expression of the desire for a more blessed life than the author's or reader's own, which we can understand as a desire, however conscious, for the God in whom Christian faith believes that such a life is to be found.

A very different theistic response to post-structuralism is found in George Steiner's Real Presences (1989). The book begins with the premise that a belief in the communicative function of language is ultimately founded on a belief in the presence of God to the world. Aesthetic meaning in particular, Steiner writes, implies the 'necessary possibility' of this presence. ${ }^{195} \mathrm{He}$ asserts that communication in language, particularly in the form of great literary works, occurs as result of a 'wager on transcendence', that is, on a real otherness made present in language, whose presence ultimately derives from that of God. ${ }^{196}$ Steiner argues in favour of making this wager in the name of a responsible experience of art.

In the first section, Steiner denigrates the prevalence of secondary discourse in contemporary culture, the proliferation of texts about texts, which he describes as a deliberate avoidance of confrontation with the mystery of creation embodied in a work of art. ${ }^{197}$ In the second section, he traces the history of the 'broken contract' between language and the world characteristic of modernity, which he

195 George Steiner, Real Presences: Is There Anything In What we Sav? (London and Boston: Faber and Faber, 1989) p. 3.

196 Ibid. p. 4

197 Tbid. p. 49. 
plots from Mallarmé and Rimbaud through to post-structuralism. Steiner calls this period the 'after-Word' or 'epilogue', since it supersedes a belief in the sayability of being. ${ }^{198}$ Deconstruction, the most radical of the denials of presence, Steiner finds irrefutable 'on its own terms and planes of argument'. ${ }^{199}$ Neither linguistics nor literary theory, he argues, can offer counter-arguments that deconstruction cannot compromise. Nevertheless, it is 'manifestly false to human experience' ${ }^{200}$ What is necessary if one is to maintain a belief in the reality of those things expressed in language, Steiner writes, is to envisage 'foundations beyond the empirical'. ${ }^{201}$ In the final section of the book, he offers a phenomenological account of art, based on the assertion that the experience of art is fundamentally an experience of otherness, whose paradigm is the Annunciation, "a terrible beauty"...breaking into the small house of our...being' ${ }^{202}$ Steiner writes that this encounter is necessarily moral, and brings with it a call to change. It can be described by a 'phenomenology of courtesy', which traces a silent and responsive welcome of the other in a work of art as a guest into the house of the critic's being. ${ }^{203}$ Steiner calls this critical receptivity 'philology', and asserts that it is based on 'an axiom of dialogue'204. With respect to the production of art-works, Steiner writes, 'There is aesthetic creation because there is creation, ${ }^{205}$ In an agonistic relation with the inexplicable thereness of created beings, an artist works a 'counter-creation', motivated by a pious rage that he comes after the original mystery of form. ${ }^{206}$ The otherness

\footnotetext{
198 Ibids p. 94.

199 Ibid. p. 132.

${ }^{200}$ Ibid. p. 213.

201 Ibid. p. 134.

202 Ibid. p. 143.

203 lbid. p. 148.

${ }^{204}$ Ibid. pp. 155, 198.

205 Ibid. p. 201.

${ }^{206}$ Ibid. p. 203.
} 
experienced in a work of art is, for Steiner, a correlate of the otherness of creation which stimulates the artist. ${ }^{207} \mathrm{He}$ writes that the gravity of art is 'finally, religious', enacting the impulse of the human spirit to explore the unknown and our closeness to it. ${ }^{208}$ The various forms of art, he asserts, 'relate us most directly to that in being which is not ours'. 209

Steiner does not write Christian literary theory in our sense of the term, but there are several points in his argument that we can use in such a theory. We can accept his assertion that reading a fictional work can provide an experience of certain aspects of human existence that cannot be articulated in empirically verifiable discourse. We can take this as one of the specific goods of fiction. Whilst we need not follow his assertion that literary production is a response to the mystery of existence, we can accept that such production can in part consist of an exploration of those aspects of human existence that cannot be articulated in logical propositions. We need not assert with Steiner that the expression of that which cannot be contained in such propositions but which the reader nevertheless feels to be true is necessarily related to the existence of God of or his creation of the world, but we can accept the principle that Christian criticism might seek to relate the expression of the transcendent qualities in human existence that the critic discerns in a text to his or belief in the divine creation of that existence.

I will conclude this section with an examination of some of the essays in Christian literary theory that have appeared in journals devoted to literature and religion in recent years. Some of these essays reject the apparent nihilism of contemporary theory, in the name of Romantic and formalist ideas, and others 
look towards an assimilation of post-modern thought. The most articulate statement of the former position is the evangelical critic Leland Ryken's essay, 'The Contours of Christian Criticism in 1987 ' (1987). There he argues for a distinctively Christian method of literary criticism, which will add a distinctively Christian voice to the plurality of conceptual schemes from which critical discourse is now derived. ${ }^{210} \mathrm{He}$ writes that this should consist of a return to Eliot's two-tier criticism, to the traditional Western canon and to a nonpoliticised criteriology. Clarence P. Walhout, prominent among those Christian critics who seek to assimilate the insights of contemporary theory, argues in response to these assertions that the modern re-assessment of the canon and the politicisation of critical discourse are motivated by a concern for social justice, of which Christian critics should be at the forefront. ${ }^{211}$ For Walhout, a distinctively Christian critical discourse will evolve not through rejection of modern revaluations, however secular, but through engagement with them. If such discourse is to be relevant in contemporary society, we must agree with Walhout on this point. Whilst we can accept with Ryken that, since all critical discourse derives from some system of first principles, Christian criticism should derive from principles of or compatible with Christian theology, we cannot agree that such a discourse will be constituted by a simple rejection of the last thirty years' developments in literary theory, however hostile they have been to Christian faith.

In his essays 'Literary Criticism in the Christian Community' (1979) and 'A New Direction For Christian Literary Theory' (1981), Walhout argues that

\footnotetext{
${ }^{209}$ Ibid. p. 226.

${ }^{210}$ Leland Ryken. 'The Contours of Christian Criticism in 1987', Christianitv and Literature 37 (1987) pp. 23-36.
} 
Romantic theory is at odds with the element of community in Christian theology. He writes that the emphasis on the autonomy of the individual consciousness, which he discerns in the criticism of Eliot and phenomenological criticism, is in conflict with a Christian view of community. ${ }^{212}$ Although Romantic theories have dominated Christian literary thought, Walhout looks for a more historical hermeneutics that takes account of the construction of meaning in community as the model for Christian criticism. ${ }^{213}$ Mark Walhout takes a similar position in his article 'Aesthetic Experience and Social Justice' (1987). He cites the conclusions of various ecumenical bodies in support of his contention that Christian criticism, like all criticism, is of itself politically significant. What counts, for Walhout, is that its politics should express 'the biblical vision of social justice', affirmed by such organisations as the World Council of Churches. ${ }^{214} \mathrm{He}$ describes the period 1840-1870 in America as one of 'Romantic Christianity', in which aesthetic experience was accorded the status of a near-religious epiphany. ${ }^{215} \mathrm{He}$ writes that this tradition is still active today. Its religious aestheticism, Walhout asserts, involves a 'failure to think through the contingent and situated nature of aesthetic experience', which 'obstructs inquiry into the historical conditions and effects of works of art'. ${ }^{216}$ The description of aesthetic experience in the terms of religious experience in this tradition, Walhout writes, tends to obscure the historical situation of an art-work and of its reception, with

${ }^{211}$ Clarence Walhout. 'A Response to Leland Ryken's Proposals For Christian Literary Critics', Christianity and Literature 37 (1987) p. 42.

212 Clarence P. Walhout, 'Literary Criticism in the Christian Community', Christian Scholar's Review 8 (1979) pp. 298-304.

${ }_{213}$ Patricia A. Ward also argues for an attention to the situation in which the meaning of a work is constructed by the reader by Christian critics. See her articles 'Worldly Readers and Writerly Texts', Christian Scholar's Review 17 (1988) pp. 433-435, and 'Ethics and Recent Literary Theory: The Reader as Moral Agent', Religion and Literature 22 (1990) pp. $21-31$.

${ }_{214}$ Mark Walhout, 'Aesthetic Experience and Social Justice: Historical Reflections on Christian Criticism', Christian Scholar's Review 16 (1987) p. 250.

215 Ibid. p. 252. 
which Christian criticism should be concerned. In his opinion, such criticism should temper its attention to the epiphanic and sacramental qualities of art with an attention to the social situation in which works are produced.

We can take from these essays the principle that Christian criticism has an ethical commitment to analysing the relations of a text to the social and political situations in which it was produced and in which it is read. We can follow Clarence Walhout in asserting that, since meaning is a communal event, the meanings of a text cannot be determined outside these situations. We can follow Mark Walhout in asserting that one task of Christian criticism might consist of an analysis of these situations, insofar as they can be shown to determine a text, in the terms of Christian social ethics.

In his essay 'The Problem of Moral Criticism in Christian Literary Theory' (1994), Clarence Walhout argues that this principle should be applied to the Christian critic's own discourse, in particular to the moral norms that he or she uses in it. He cites Alisdair MacIntyre's argument in After Virtue (1981) that moral principles take on meaning in the context of developing social practices, and argues that the principles used-as norms by-Christian criticism should be examined in their relation to such practices rather than as trans-historical or as absolute. As these practices evolve, so do the moral principles which derive from them. As a result, Walhout writes, 'Moral criticism of literature demands reflection on moral principles as well as... on literary texts'. ${ }^{217}$ Citing Gadamer, he asserts that the values of the text and of the critic are to be understood in the light of one another. ${ }^{218}$ This makes criticism a process in which 'we learn to

\footnotetext{
${ }^{216}$ Ibid.

${ }^{217}$ Clarence P. Walhout. 'The Problem of Moral Criticism in Christian Literary Theory', Christian Scholar's Review 24 (1994) p. 40.

${ }_{218}^{2}$ Ibid. p. 43.
} 
develop and modify our own beliefs and values by interaction with the beliefs and values of others' ${ }^{219}$ Wathout makes a significant point in this essay on the nature of the ethical principles in whose terms I have argued that Christian criticism should analyse texts-and their-contexts, with which we can agree. Since these principles are not universal but constitute the current historical state of the practice of Christian -ethics, Christian literary theory should recognise the historical specificity of its own interpretative standards. We can accept from Walhout that-this means that one task of Christian criticism might consist in an examination of the critic's own ethical principles in the terms of those he or she finds expressed -in the texts and its receptions as well as-vice wersa.

This concludes my examination of modern Christian literary theories. I have argued that Gadamer's hermeneuties legitimates the concept of Christian literary theory, and I have analysed the contributions to such a theory of this hermeneutics, of neo-Thomism and of modern Christian criticism. I have assessed which elements of these discourses could be used in a contemporary Christian literary theory. I have been-accreting a series of principles throughout this thesis which I have argued should constitute elements of such a theory. In the following conclusion, I will synthesise these principles into a systematic presentation of the Christian literary theory towards which I have been working

${ }^{219}$ Ibid. p. 44 


\section{Conclusion}

In the last two chapters, I have argued that there is a tradition of Christian thought that pertains to what we now call literary theory. This tradition is diverse and fragmentary. The philosophers, theolegians and critics I have examined have been concerned with a variety of subjects, for a variety of reasons, and have argued with reference to a variety of first principles. None has claimed that his or her thought, insofar as it pertains to literary theory, is systematic. In this conclusion, I will use some of these diverse insights to sketch a literary theory which is both derived from Christian faith or from principles consistent with it, and which takes account of the objections to such a concept posed by the fundamental discourses of contemporary theory, deconstnuction, Marxism and psychoanalysis.

After deconstruction, we need to emphasise the provisional nature of the propositions which constitute the intelligible content of the Christian faith, and from which Christian literary theory, as I have defined it, will derive. This is not a new caveat in theology. In his essay 'What is a Dogmatic Statement?' (1962), Wolfhart Pannenberg argues from an eschatological perspective that the final truth of Christian dogmas is deferred until the promised end of history:

The church's dogma, which is still on the way, cannot itself be the eschatological for $m$ of revealed truth. It always remains under the... sign of the 'not yet', which characterises all Christian life and thought.'

\footnotetext{
' Wolfhart Pannenberg, Basic Questions in Theology Vol. 1, tr. George H. Kclım (London: SCM Press, 1970) p. 210.
} 
Pannenberg sees in the church's revision of its confessional formulations an example of their provisional quality, which he calls their 'not yet'. In 'The Development of Dogma' (1954), Karl Rahner argues a similar point from a Catholic perspective. He writes that doctrinal development is a consequence of the limited scope of human statements, itself a consequence of the limited scope of human knowledge in comparison to God's 'simple and exhaustive knowledge of himself and of all that takes its origin from him'. ${ }^{2}$ Rahner writes:

All human statements, even those in which faith expresses God's saving truths, are finite... They never declare the whole of a reality. ${ }^{3}$

In Rahner's view, every reality is related to every other reality, so that even the simplest empirical observation is essentially limited. It is all the more certain, on this account, that doctrinal statements concerning divine realities 'can never express them once and for all in an entirely adequate form'. Any such formulation is in principle open to hitherto unforeseen possibilities of meaning. Deconstruction tells us that the language of Christian doctrine subverts the metaphysical system on which it is based. The meaning of a doctrinal statement, that is, is never final or absolute. On the contrary, its meaning is provisional, and believed within the community of faith as the best expression currently possible of a reality that can never be fully or adequately expressed in the metaphysical structure of language. This view is not without support from deconstruction. On the one hand Derrida points out that a non-metaphysical language does not exist and that it is therefore necessary to use the existing language whilst pointing out the limits of its apparent structure of reference. In theological terms, this is to say that negative theology tells us most about God. On the other hand, Derrida

\footnotetext{
${ }^{2}$ Karl Rahner, Theological Investigations Volume 1: God, Christ, Marv and Grace, tr. Cornelius Ernst (London: Darton, Longman and Todd, 1961) p. 44.

${ }^{3}$ lbid. p. 43.
} 
suggests that commitment to a reality outside discourse towards which the latter inadequately gestures is possible despite its deconstruction, when he speaks of his commitment to political action in the face of the deconstruction of political language. As Hans-Georg Gadamer points out, deconstruction does not account for the hermeneutic dimension of language, that is, for the community which is its precondition. Christian doctrines are formulated, believed, reflected upon and reformulated in the community of faith, not as encryptions of a fixed quantity of meaning but in dialogue with the church and with the God who reveals himself in it. By their 'provisional' quality, I mean that, whilst structurally inadequate, Christian doctrines are nevertheless understood in the community of faith as the best possible expression of God's saving will at the current stage of the dialogue by which that community is constituted.

There is much in the social ethics of Marxist literary theory which Christian literary theory can and should adopt. Marx's atheism does not make this proposition inconsistent since, like Feuerbach's projection-theory from which it derives, that atheism is founded ultimately on an unproved hypothesis. The indisputable influence of social and economic factors in religious ideas does not imply either the existence or the non-existence of a reality corresponding to those ideas. Hans Küng calls the Marxist process of arguing from the idea of God to his non-existence 'a kind of ontological argument in reverse', which has the same flaws as its positive counterpart. ${ }^{5}$ Marx's critique of the systematic economic exploitation by a powerful minority, which controls and influences the legislature, of the majority of wage-earning labourers and his call for an end to this exploitation are strongly anticipated and affirmed by the Bible, and must be

\footnotetext{
${ }^{4}$ Ibid. p. 44.
} 
a fundamental concern of Christian ethics. Insofar as Marxist literary theory provides methods for an ethical analysis of the social and economic situations in which literary texts are produced and received, Christian literary theory should endorse them. It is not committed to Marxism as the truth distorted by the classinterests it may discern in this way, however. As I argued in the second chapter, the criteria for the distinction between Marxist representation and bourgeois misrepresentation of historical reality are not consistently maintained, but ultimately devolve onto an appeal to the authority of Marxist texts. Furthermore, Christian anthropology is fundamentally different to that of Marxism, in that it does not subordinate the humanity, dignity or capacity for self-transcendence of the individual to the social formation as a whole. Whilst Christian literary theory can and should use the socio-economic perspectives on literary texts described by Marxist literary theories, it will also maintain that these perspectives do not exhaust the meaning of such texts.

Psychoanalytic literary theory is of less consequence for Christian literary theory, primarily because psychoanalysis is essentially untestable. As I argued in the third chapter, there is in principle no way of checking Freud's theories of unconscious mental processes. He does not allow that his preferred method of reconstructing an analysand's unconscious history from dream-interpretation, free-association and similar techniques is susceptible of conscious judgement by the analysand. As for empirical investigation, we saw that, despite a rhetoric of observation, Freud in practice asserts that for several reasons psychoanalytic hypotheses are not susceptible of confirmation by such investigation. These hypotheses are in the end simply assertions, whose truth-value is undecidable.

\footnotetext{
${ }^{5}$ Hans Küng, Does God Exist? An Answer for Today, tr. Edward Quinn (London: Collins, 1980) p. 245 .
} 
There is no reason in principle why Christian literary critics should not use psychoanalytic critical methods, since Freud's atheism, like Marx's, is based on Feuerbach's fallacious projection theory. Indeed, psychoanalytic accounts of the tension between opposing forces in the psyche are not incompatible with a Christian anthropology of $\sin$ and grace. Nevertheless, there is no reason to believe that psychoanalytic criticism describes any reality with respect to literary texts, and hence no reason for Christian literary critics to use its methods. This is particularly so in view of the inadequacy of psychoanalytic accounts of femininity. Even if psychoanalysis is taken as a system of cultural hermeneutics rather than as an empirical science, its use in explaining issues pertaining to femininity in critical analysis will be limited.

We can now go on to describe some of the positive content of the Christian literary theory whose contemporary conditions we have determined. A Christian theory of language could only be a second-order reflection on contemporary philosophy of language, as we have seen from Augustine's use of Stoic and Neoplatonic metaphysics and Aquinas' use of Aristotle's. This is also the case with modern theological theories of language such as John Macquarrie's GodTalk (1967), based on existentialism, and Nicholas Wolterstorff's Divine Discourse (1995), based on speech-act theory. Nevertheless, we can set out some basic principles concerning language, insofar as it is an object of literary theory, which are compatible with the deposit of Christian faith. Firstly, we can take the Biblical text in which Adam names the animals brought to him by Yahweh to indicate that, considered as a structure, language is a means of appropriating and ordering a world which human beings have not created, but in which they find 
themselves. We open up, order and incorporate the otherwise alien and incomprehensible world into our experience by means of lexical and grammatical structures. Secondly, as Augustine and Aquinas among others point out, men and women are social animals, and they organise their lives together by means of discourse. A shared understanding of some aspect of existence is almost always the goal of utterance. As John Macquarrie writes, 'Some aspect of the shared world is lit up, and made accessible to both parties in the discourse'. 6 This is not to say that statements convey a fixed quantity of meaning which is decoded by a receiver. On the contrary, communication presupposes a community of interpretation, in which the rules of signification and the context in which signs are to be understood is developed. The meaning of a sign is always interpreted within a community. As Augustine points out, anticipating certain post-structuralist ideas, the meaning of a written text, with whose author a reader cannot engage in dialogue, cannot be determined in terms of the quantum of meaning the author intended to encode in the text. On the contrary it is always interpreted from within the historical situation of the reader. Finally, the communal nature of discourse makes it a vehicle of the power-relations by which communities are structured. The story of the tower of Babel tells us that discourse can be used for force in society, to consolidate interests and to maintain unjust social organisations, and that such discourse, which we can call ideological, is against God's will for society. When we analyse literary texts and their interpretations from a Christian perspective, we must include an ethical analysis of their social effects as communications.

\footnotetext{
${ }^{6}$ John Macquarrie. God-Talk: An Examination of the Language and Logic of Theology (London: SCM Press, 1967 ) p. 74.
} 
A Christian theory of literary production can begin with the analogy of literary production and the divine act of creation. As Thomas Aquinas says, in the sense that divine creation can be understood by analogy with the human faculty of making things as our intellect determines that they should be, it can be said that the universe was produced by the divine art, and is God's work of art. God's creation by his Word can be understood, in Jacques Maritain's phrase, as the 'supreme analogate' of literary production. The process of writing a fictional work, like all acts of making, is an analogous imitation and repetition of the divine making. Such writing is not a creation ex nihilo, however. As St. Thomas says, it is 'a kind of labour', whose raw materials are the structure of language and the discourses or fields of language-use available to the author in his or her historical situation. ${ }^{7}$ Aquinas' definition of a liberal art as analogous to physical work reminds us of the essential role of the body in literary production. The practice of silent reading can disguise the essentially physical nature of the language that is worked into a text. The literary product is a new being in language, a new 'form' in the Thomistic sense, which is to say that writing a fictional text is not only an imitation and repetition of the divine creativity but also a continuation of it. The production of language and discourses into a text furthers the process by which God brought all the material of language and discourses into being. This is what Aquinas means when he calls art an 'imitation of nature in its operation'.

The Bible tells us, at Ex. 31:1-6 and 36:1, that the capacity for artistic production in general is a divine charism, a gift of the Holy Spirit, which we can take to be true of literary production in particular. The Biblical doctrine of

\footnotetext{
${ }^{7}$ Thomas Aquinas, Strmma Theologiae la-Ilae 57, 3.

${ }^{8}$ Ibid. Ia $117,1$.
} 
spiritual gifts situates them within the baptismal community of the church, but we can think of literary production as a kind of natural analogue of these gifts, in accordance with the assertion of the Catechism of the Catholic Church that "the human person participates in the light and power of the divine Spirit'. ${ }^{9}$ As Vatican II describes cultural production, in Gaudium et Spes (1965), 'The triumphs of the human race are...the flowering of [God's] own mysterious design'. ${ }^{10}$ We can add that, as Jacques Maritain argues, the production of a new linguistic form or entity presupposes a certain degree of awareness of the forms and natural processes of the world brought to light in the languages and discourses of which the text is a production. However consciously, this is tantamount to an awareness of the God who brought these forms and natural processes into being.

A Christian theory of literary reception will understand reading a literary text as an engagement in dialogue with the author, as an interpretation within a given community of those aspects of existence of which the reader understands the text to be a communication. Literary texts make a 'claim', in Gadamer's phrase, on the reader; that is, they speak to him or her in a way that demands a response. Reading is a process of engaging with this claim in the ways determined by the historical situation of the reader's community. By accepting and rejecting the insights and views he or she understands the text to express or to imply, the reader's understanding of these aspects of existence changes. Fictional texts can provide readers with ways in which to interpret their experience, and even with a

\footnotetext{
${ }^{9}$ Catechism of the Catholic Church, English translation (London: Geoffrey Chapman, 1994) no. 1704.

${ }^{10}$ Gaudium et Spes no. 34, in Walter Abbott and Joseph Gallagher, tr. and ed., The Documents of Vatican II (New York: Association Press, 1966) p. 232. Cp. Pope Paul VI's sermon. 'The Friendship of Artists and the Church'. The Pope Speaks 9 (1964), where he speaks of 'the charism of art' (p. 393).
} 
recognition of certain aspects of this experience of which they were previously unaware. These interpretations and recognitions can call a reader to change his or her life.

We can take the degree to which a text allows a reader this kind of insight into some previously hidden aspect of existence as an index of its value. As Maritain argues, a greater knowledge of things is tantamount to a greater knowledge of the God who brought them into being. These insights can be ethical, that is, they can concern the injustice or misery of things, and, by implication a knowledge of God's will against them. As St. Augustine says, the experience of beauty in reading is the experience of being put in mind of a happier, more blessed and more profoundly satisfying life than one's own. At 1 Cor. 12:7, St Paul tells us that the gifts of the Spirit are given 'for the common good'. We can take this index of value as one way in which literary texts function for the good of their readers, and we can add that, as Thomas Aquinas says, one of the goods of fiction in general is recreation for the mind, which, in taking pleasure in fictional products, rests from the tasks and anxieties of working life. Whilst the good of fiction is pleasure, that is, the most valuable of its pleasures is that for some readers some texts teach them something about their existence. As Eric Gill argues, this experience is kept from or discouraged in most people by the working conditions of industrial and technological capitalism.

As modern literary theory has made clear, all critical practice implies a theory. There is no literary criticism or cultural study that does not refer to a more or less consciously articulated system of beliefs and norms. As Nathan Scott wrote, a critical practice that derives its judgements from Christian theology is 'a 
legitimate and necessary enterprise of the Christian intelligence'. "Whilst a Christian critical practice will vary according to the social and historical situation in which it is practised, it seems to me that at present a Christian critic could employ some of the following methods. He or she could analyse the ways in which the text presents itself as an interpretation of the world and of how to act in it. To the degree that a text does so, we can say that it fulfils the religious role once played by myth, in the sense in which that term can be understood to denote a story expressing or symbolising fundamental aspects of human existence and its limits. The Christian critic could analyse and judge the relation of this kind of story as he or she understands it in the text to the Christian narratives. Many literary genres, particularly dramatic forms such as tragedy and comedy, appear to have their origins in ritual, and the critic could discuss the traces of religious significance he or she can still discern in such texts. In this dialogue with the world-view he or she discerns in the text, the Christian critic should remain open to the possibility of an ethical critique of the historical church or of individual Christian practice.

A Christian critic could analyse the social and political context in which a text was produced, insofar as the text can be seen to be determined by this context, in terms of Christian social ethics. We can take as a basic formulation of such ethics Vatican II's assertion:

The political community exists for that common good in which the community finds its full justification and meaning, and from which it derives its... proper right. The common good embraces the sum of those conditions of social life by which individual, families, and groups can achieve their own fulfilment in a relatively thorough and ready way. ${ }^{12}$

\footnotetext{
"Nathan A. Scott, 'The Relation of Theology to Literary Criticism', Journal of Religion XXIII (1953) p. 268.

${ }^{12}$ Gaudium et Spes no. 74.
} 
As Timothy J. Gorringe argues, in Capital and the Kingdom (1994), "The concern of Christian ethics is fullness of life, and this means that economics is at the heart of ethical concern, for...the control of the production of wealth is the control of human life itself ${ }^{13}$ Insofar as the Christian critic can discern in a text the effects of the socio-economic and political conditions in which it was produced, he or she could analyse the degree to which these conditions prevented or allowed individuals or groups to realise their own fulfilment. He or she could examine the history of receptions of a text in the same terms. José Miranda and other liberation theologians have shown that this is a profoundly Biblical concern, and so that the relations of a text to social injustice and to desires and forces for its redress in general are a necessary field of Christian criticism. In this way, such criticism would represent a transposition of Augustine's principle of interpretation according to charity into literary hermeneutics.

\footnotetext{
${ }^{13}$ Timothy J. Gorringe, Capital and the Kingdom: Theological Ethics and Economic Order (London: SPCK, 1994) p. 159.
} 


\section{Bibliography}

Abbott, Walter M. and Joseph Gallagher, tr. and ed., The Documents of Vatican II, New York: Association Press, 1966.

Abrams, M.H., Natural Supernaturalism: Tradition and Revolution in Romantic Literature, New York and London: Norton, 1971.

Adler, Gerhard, and Aniela Jaffé, eds., Letters of C.G. Jung, London: Routledge, 2 vols., $1973-1976$.

Althusser, Louis, For Marx, tr. Ben Brewster, London: NLB, 1969.

Lenin and Philosophy and Other Essays, tr. Ben Brewster, London: NLB, 1971.

Althusser, Louis, and Étienne Balibar, Reading Capital, tr. Ben Brewster, London: Verso, 1970

Altizer, Thomas J.J., et al., Deconstruction and Theology, New York: Crossroads, 1982

Aquinas, Thomas, Opera Omnia, 7 vols., ed. Roberto Busa et al., Stuttgart: Fromann-Holzboorg, 1980.

Summa Theologiae, Blackfriars edition and translation, 60 vols., London and New York: Eyre and Spottiswoode, 1964-1976.

Selected Philosophical Writings, tr. and ed. Timothy McDermott, Oxford and New York: Oxford University Press, 1992.

The Philosophy of Thomas Aquinas: Introductory Readings, tr. and ed. Christopher Martin, London and New York: Routledge, 1988.

Aristotle on Interpretation: Commentary by St. Thomas and Cajetan, tr. Jean

T. Oesterle, Milwaukee: Marquette University Press, 1962. 
Arrington, French L., The Acts of the Apostles: An Introduction and Commentary, Peabody, MA: Hendrickson, 1988.

Atkins, G. Douglas, 'Partial Stories: Hebraic and Christian Thinking in the Wake of Deconstruction', Religion and Literature 15 (1983), 7-21.

Attridge, Derek, Geoff Bennington and Robert Young, eds., Post-Structuralism and the Question of History, Cambridge: Cambridge University Press, 1987.

Sancti Aurelii Augustini, Hipponensis Episcopi, Opera Omnia, ed. J.-P. Migne, Patrologia Latina Vols. 32-47 (Paris, 1861-1862).

S. Aurelii Augustini Hipponensis Episcopi de Catechizandis Rudibus Liber Unus, tr. Joseph Patrick Christopher, Washington, DC: Catholic University of America Press, 1926.

Saint Augustine: The Immortality of the Soul, The Magnitude of the Soul, On Music, The Advantage of Believing, On Faith in Things Unseen, tr. Ludwig Schopp et al., Washington, DC: Catholic University of America Press, 1947.

Saint Augustine: The Happy Life, Answer to Skeptics, Divine Providence and the Problem of Evil, Soliloquies, tr. Ludwig Schopp et al., New York: Cima, 1948.

Augustine: Earlier Writings, tr. and ed. John H.S. Burleigh, Philadelphia: Westminster Press, 1953.

Augustine: Later Works, tr. and ed. John Burnaby, Philadelphia: Westminster Press, 1955.

On Christian Doctrine, tr. D.W. Robertson, Jr., New York: Macmillan, 1958.

Confessions, tr. R.S. Pine-Coffin, London: Penguin, 1961. 
Scaint Augustine: The Trinity, tr. Stephen McKenna, Washington, DC: Catholic University of America Press, 1963.

Concerning the City of God against the Pagans, tr. Henry Bettenson, London: Penguin, 1972.

Saint Augustine on Genesis: Two Books on Genesis against the Manichees, and, On the Literal Interpretation of Genesis: An Unfinished Book, tr. Roland J. Teske, Washington, DC: Catholic University of America Press, 1991.

Ayers, Robert H., Language, Logic and Reason in the Church Fathers: A Study of Tertulliam, Augustine and Aquinas, Hildesheim and New York: Georg Olms Verlag, 1979.

The Babylonian Talmud: Shabbath, tr. and ed. I. Epstein and H. Freeman, London: Soncino Press, 1938.

Balakian, Anna, 'Jacques Maritain on the Frontiers of Poetry', Renascence: Essays on Value in Literature 34 (1982), 245-259.

Baratin, Marc, 'Les Origines Stoïciennes de la Théorie Augustinienne du Signe', Révue des Études Latines 59 (1981), 60-83.

Barrett, C.K., The Gospel According to St. John: An Introduction with Commentary and Notes on the Greek Text, $2^{\text {nd }}$ ed., London: SPCK, 1978. A Critical and Exegetical Commentary on the Acts of the Apostles, Vol. I, Edinburgh: T. \& T. Clark, 1994.

Barthes, Roland, Image Music Text, tr. Stephen Heath, London: Fontana, 1977.

Battenhouse, Roy W., ed., A Companion to the Study of St. Augustine, New York: Oxford University Press, 1955. 
Behler, Ernst, 'Deconstruction Versus Hermeneutics: Derrida and Gadamer on Text and Interpretation', Southern Humanities Review 21 (1987), 201223.

Belsey, Catherine, Critical Practice, London and New York: Routledge, 1980.

Bennett, Tony, Formalism and Marxism, London: Methuen, 1979.

Outside Literature, London and New York: Routledge, 1990.

Bennington, Geoffrey, 'Not Yet', Diacritics 12 (1982), 23-32.

'Deconstruction and the Philosophers (The Very Idea)', Oxford Literary Review 10 (1988), 73-130.

Geoffrey Bennington and Jacques Derrida, Jacques Derrida, tr. Geoffrey Bennington, Chicago and London: Chicago University Press, 1993.

Berthoud, J.A., 'Narrative and Ideology: A Critique of Fredric Jameson's The Political Unconscious', in Narrative: From Malory to Motion Pictures, ed. Jeremy Hawthorn, London: Edward Arnold, 1985, pp. 101-116.

Bleicher, Josef. Contemporary Hermeneutics: Hermeneutics as Method, Philosophy and Critique, London: Routledge and Kegan Paul, 1980.

Biblia Hebraica, ed. Rudolf Kittel, Paul Kahle et al., $7^{\text {th }}$ ed., Stuttgart: Privilegierte Würtenburgische Bibelanstalt, 1951.

Block, Ed Jr., 'Gadamer, Christian Tradition and the Critic', Renascence: Essays on Value in Literature 41 (1989), 21 1-232.

Bloom, Harold, Agon: Towards a Theory of Revisionism, New York and Oxford: Oxford University Press, 1982.

Bloom Harold, et al., Deconstruction and Criticism, New York: Continuum, 1979. 
Bonaparte, Marie, The Life and Works of Edgar Allen Poe, London: Imago, 1949.

Bonino, José Miguez, Christians and Marxists: The Mutual Challenge to Revolution, Grand Rapids, MI: Eerdmans, 1976.

Borgen, Peder, Logos was the True Light, and Other Essays on the Gospel of John, Trondheim: Tapir, 1983.

Borger, Robert and Frank Cioffi, eds., Explanation in the Behavioural Sciences, Cambridge: Cambridge University Press, 1970.

Bost, Hubert, Babel: Du Texte an Symbole, Geneva: Labor et Fides, 1985.

Bowie, Malcolm, Lacan, London: Fontana, 1991.

Brooks, Cleanth, 'Religion and Literature', Sewanee Review LXXXII (1974), 93-107.

Brueggemann, Walter,Genesis, Atlanta: John Knox Press, 1982.

Bridgman, Laird P. and John D. Carter, 'Christianity and Original Sin: Oedipal or Pre-Oedipal?', Journal of Psychology and Theology 17 (1989), 3-8.

Brown, Raymond E., The Gospel According to John, Garden City, NY: Doubleday, 1966.

Bruce, F.F., Commentary on the Book of Acts: The English Text with Introduction, Exposition and Notes, $2^{\text {nd }}$ ed., London and Edinburgh: Marshall, Morgan and Scott, 1965.

Bruns, Gerald L., 'What is Tradition?', New Literary History 22 (1991), 1-21.

de Bruyne, Edgar, Etudes d'Ésthétique Mediévale Vol. III: Le XIIIe Siècle, Bruges: De Tempel, 1946. 
Bultmann, Rudolf, The Gospel of John: A Commentary, tr. G.R. BeasleyMurray, R.W.N. Hoare and J.K. Riches, Philadelphia: Westminster, 1971.

Callinicos, Alex, Marxism and Philosophy, Oxford and New York: Oxford University Press, 1983.

Carr, Brian, Metaphysics: An Introduction, London: Macmillan, 1987.

Cassuto, Umberto, A Commentary on the Book of Genesis, 2 vols., tr. Israel Abrahams, Jerusalem: Magnes Press, 1964

Childs, Brevard S., Exodus: A Commentary, London: SCM Press, 1974.

Cioffi, Frank, 'Exegetical Myth-Making in Grünbaum's Indictment of Popper and Exoneration of Freud', in Peter Clark and Crispin Wright, eds., Mind, Psychoanalysis and Science, Oxford: Blackwell, 1988, pp. 61-87.

Clark, Timothy, Derrida: Heidegger, Blanchot: Sources of Derrida's Notion and Practice of Literature, Cambridge: Cambridge University Press, 1992.

Code of Canon Law: Latin-English Edition, Washington, DC: Canon Law Society of America, 1983.

Codex Iuris Canonici, Vatican City: Typis Polyglottis Vaticanis, 1931.

Coggins, R.J., The First and Second Books of the Chronicles, Cambridge: Cambridge University Press, 1976.

Colish, Marcia L., The Stoic Tradition from Antiquity to the Middle Ages Vol. I, Leiden: E.J. Brill, 1985.

Coomaraswamy, Ananda K., 'Medieval Aesthetic II: St. Thomas Aquinas on Dionysius, and a Note on the Relation of Beauty to Truth', Art Bulletin $20(1938), 66-77$ 
Copleston, F.C., A History of Philosophy Vol. II: Medieval Philosophy, Augustine to Scotus, London: Burns, Oates and Washbourne, 1950.

Aquinas, London: Penguin, 1955.

A History of Medieval Philosophy, London: Methuen, 1972.

Coward, Harold and Toby Foshay, eds., Derrida and Negative Theology, New York: State University of New York Press, 1992.

Crews, Frederick, Skeptical Engagements, New York and Oxford: Oxford University Press, 1986.

Critchley, Simon, The Ethics of Deconstruction: Derrida and Levinas, Oxford: Blackwell, 1992.

Crossan, John Dominic, Cliffs of Fall: Paradox and Polyvalence in the Parables of Jesus, New York: Seabury, 1980

Culler, Jonathan, On Deconstruction: Theory and Criticism after Structuralism, Ithaca: Cornell University Press, 1983.

Nicholas of Cusa, Of Learned Ignorance, tr. Germaine Heron, London: Routledge and Kegan Paul, 1954.

Daniels, Donald E., 'The Argument of the De Trinitate and Augustine's Theory of Signs', Augustinian Studies 8 (1977), 33-54.

Dasenbrock, Reed Way, Redrawing the Lines: Analytic Philosophy, Deconstruction and Literary Theory, Minneapolis: University of Minnesota Press, 1989.

'Fredric Jameson and the Dilemmas of Late Marxism', Raritan 11 (1992), 117-130.

Davenport, Manuel M., 'Kant and Maritain on the Nature of Art', British Journal of Aesthetics 12 (1972), 359-368. 
Davies, Brian, The Thought of Thomas Aquinas, Oxford: Clarendon Press, 1992.

Deferrari, Roy J., and M. Inviolata Barry, A Lexicon of St. Thomas Aquinas, Washington, DC: Catholic University of America Press, 1947.

Denzinger, Heinrich, and Adolf Schönmetzer, eds., Enchiridion Symbolorum, Definitionum et Declarationum de Rebus Fidei et Morum, $32^{\text {nd }}$ ed., Barcinone: Herder, 1963.

Derrida, Jacques, La Voix et le Phénomène: Introduction au problème du signe dans la phénoménologie de Husserl, Paris: Presses Universitaires de France, 1967.

De la Grammatologie, Paris: Éditions de Minuit, 1967.

Speech and Phenomena and Other Essays on Husserl's Theory of Signs, tr.

David B. Allison, Evanston: Northwestern University Press, 1973.

Of Grammatology, tr. Gayatri Chakravorty Spivak, Baltimore and London: Johns Hopkins University Press, 1976.

Writing and Difference, tr. Alan Bass, London: Routledge, 1978.

Dissemination, tr. Barbara Johnson, Chicago: University of Chicago Press, 1981.

Positions, tr. Alan Bass, London: The Athlone Press, 1981.

Margins of Philosophy, tr. Alan Bass, New York and London: Harvester Wheatsheaf, 1982.

'Letter to John P. Leavey, Jr.', Semeia 23 (1982), 61-62.

Psyché: Inventions de l'cutre, Paris: Galilée, 1987.

The Post-Card: From Socrates to Freud and Beyond, tr. Alan Bass, Chicago: University of Chicago Press, 1987. 
Limited Inc., $2^{\text {nd }}$ ed., ed. Gerald Graff, Evanston: Northwestern University Press, 1989.

Acts of Literature, ed. Derek Attridge, New York and London: Routledge, 1992.

The Gift of Death, tr. David Wills, Chicago and London: University of Chicago Press, 1995.

Detweiler, Robert, ed., Semeia 23: Derrida and Biblical Studies (1982).

Devereaux, Mary, 'Can Art Save Us? A Meditation on Gadamer', Philosophy and Literature 15 (1991), 59-73.

Diogenes Laertius, Lives of Eminent Philosophers, with a translation by R.D. Hicks, 2 vols., London: Heinemann, 1925.

S. Dionysius Areopagita, Opera Omnia quae Extant, ed. J.-P. Migne, Patrologia Graeca Vol. III, Paris: Garnier, 1889.

Pseudo-Dionysius Areopagite: The Divine Names and Mystical Theology, tr. John D. Jones, Milwaukee: Marquette University Press, 1980.

Pseudo-Dionysius: The Complete Works, tr. Colm Luibheid, London: SPCK, 1987.

Dodd, C.H., The Interpretation of the Fourth Gospel, Cambridge: Cambridge University Press, 1953.

Eagleton, Terry, 'Marxists and Christians: Answers for Brian Wicker', New Blackfriars 56 (1975), 465-470.

Marxism and Literary Criticism, London: Routledge, 1976.

Criticism and Ideology: A Study in Marxist Literary Theory, London and New York: Verso, 1976

Literary Theory: An Introduction, Oxford: Blackwell, 1983. 
Against the Grain: Essays 1975-1985, London and New York: Verso, 1986.

The Ideology of the Aesthetic, Oxford: Blackwell, 1990.

Ideology: An Introduction, London and New York: Verso, 1991.

Eagleton, Terry, and Drew Milne, eds., Marxist Literary Theory: A Reader; Oxford and Cambridge, MA: Blackwell, 1996.

Meister Eckhart: Teacher and Preacher, ed. Bernard McGinn, Frank Tobin and Elvira Borgstadt, New York: Paulist Press, 1986.

Eco, Umberto, The Aesthetics of Thomas Aquinas, tr. Hugh Bredin, Cambridge, MA: Harvard University Press, 1970.

Semiotics and the Philosophy of Language, London: Macmillan, 1984.

Edwards, Michael, Towards A Christian Poetics, London: Macmillan, 1984.

Eichrodt, Walther, Theology of the Old Testament, 2 vols., tr. John Baker, London: SCM Press, 1961-1967.

Ellis, John M., Against Deconstruction, Princeton: Princeton University Press, 1989

Ellmann, Maud, ed., Psychoanalytic Literary Criticism, London and New York: Longman, 1994.

Erwin, Edward, A Final Accounting: Philosophical and Empirical Issues in Freudian Psychology, Cambridge, MA and London: MIT Press, 1996.

Eysenck, Hans J., and Glenn D. Wilson, The Experimental Study of Freudian Theories, London: Methuen, 1973.

Farley-Hills, David, 'Deconstruction: A Deconstruction', Essays in Criticism 42 (1992), 173-195. 
Fay, Thomas A., 'The Problem of God-Language in Thomas Aquinas: What Can and Cannot Be Said', Rivista di Filosofia Neoscolastica 69 (1977), 385391.

Felman, Shoshana, 'Turning the Screw of Interpretation', Yale French Studies $55-56(1977), 94-207$.

Feuerbach, Ludwig, The Essence of Christianity, tr. from the German, New York: Harper, 1957.

Foucault, Michel, The Order of Things: An Archaeology of the Human Sciences, tr. from the French, London: Tavistock, 1970.

Freadman, Richard, and S.R. Miller, 'Three Views of Literary Theory', Poetics $17(1988), 9-24$

Freud, Sigmund, The Standard Edition of the Complete Psychological Works of Sigmund Freud, tr. and ed. James Strachey et al., London: The Hogarth Press and the Institute of Psycho-Analysis, 24 vols, 1953-1974. This includes the following works:

'Extracts from the Fliess Papers', I, pp. 175-280.

'Project for a Scientific Psychology', I, pp. 281-397.

Studies in Hysteria, II.

Three Essays on the Theory of Sexuality, VII, pp. 123-246.

'Analysis of a Phobia in a Five-Year-Old Boy', X, pp. 3-149.

'Five Lectures on Psychoanalysis', XI, pp. 3-56.

'The Antithetical Meaning of Primary Words', XI, pp. 155-161.

'On the History of the Psycho-Analytic Movement', XIV, pp. 1-66.

‘On Narcissism: An Introduction', XIV, pp. 163-190.

Beyond the Pleasure Principle, XVIII, pp. 1-64. 
Group Psychology and the Analysis of the Ego, XVIII, pp. 67-143.

The Ego and the Id, XIX, pp. 1-66.

'The Infantile Genital Organisation: An Interpolation into the Theory of Sexuality', XIX, pp. 140-145

'The Dissolution of the Oedipus Complex', XIX, pp. 172-179.

'The Resistances to Psychoanalysis', XIX, pp. 212-224.

'Some Psychical Consequences of the Anatomical Distinction Between the Sexes', XIX, pp. 241-260.

'Negation', XIX, pp. 234-239.

'Female Sexuality', XXI, pp. 223-243.

The Future of an Illusion, XXI, pp. 3-56.

The Penguin Freud Library, ed. Angela Roberts and Albert Dickson, London:

Penguin, 15 vols., 1973-1986. This includes:

Vol. 1: Introductory Lectures on Psychoanalysis

Vol. 2: New Introductory Lectures on Psychoanalysis

Vol. 4: The Interpretation of Dreams.

Vol. 13: The Origins of Religion.

Vol. 14: Art and Literature.

Fromm, Erich, Psychoanalysis and Religion, London: Victor Gollancz, 1951.

Gadamer, Hans-Georg, Truth and Method, tr. William Glen-Doepel, London: Sheed and Ward, 1975.

Philosophical Hermeneutics, tr. David E. Linge, Berkeley and London: University of California Press, 1976. 
'Religious and Poetical Speaking', in Myth, Symbol and Reality, ed. Alan M. Olson, Notre Dame and London: University of Notre Dame Press, 1980, pp. 86-98.

The Relevance of the Beautiful and Other Essays, tr. Nicholas Walker, Cambridge: Cambridge University Press, 1986.

Gallop, Jane, Feminism and Psychoanalysis: The Daughter's Seduction, London: Macmillan, 1982

Geras, Norman, 'Althusser's Marxism: An Account and Assessment', New Left Review 71 (1972), 57-86.

Gerhart, Mary, The Question of Belief in Literary Criticism: An Introduction to the Hermeneutical Theory of Paul Ricoeur, Stuttgart: Akademischer Verlag, 1979

Gill, Eric, Art Nonsense and Other Essays, London: Cassell and Co., 1929

Beauty Looks After Herself, London: Sheed and Ward, 1933.

Christianity and the Machine Age, London: The Sheldon Press, 1940.

Gilson, Étienne, Christian Philosophy in the Middle Ages, London: Sheed and Ward, 1955

The Christian Philosophy of Saint Augustine, tr. L.E.M. Lynch, London: Victor Gollancz, 1961.

Gorringe, Timothy J., Capital and the Kingdom: Theological Ethics and Ecocnomic Order, London: SPCK, 1994.

Greimas, A.J., and François Rastier, 'The Interaction of Semiotic Constraints', Yale French Studies 41 (1969), 86-105.

Grenz, Stanley J., and Roger E. Olson, 20 $0^{\text {th }}$-Century Theology: God and the World in a Transitional Age, Carlisle: Paternoster Press, 1992. 
Grosz, Elizabeth, Jacques Lacan: A Feminist Introduction, London and New York: Routledge, 1986.

Guberman, Ross Mitchell, ed., Julia Kristeva: Interviews, New York: Columbia University Press, 1996.

Gutiérrez, Gustavo, A Theology of Liberation: History, Politics and Salvation, tr. Caridad Inda and John Eagleson,, London: SCM, 1988.

Habermas, Jürgen, On the Logic of the Social Sciences, tr. Sherry Wieber Nicholsen and Jerry A. Stark, Cambridge: Polity Press, 1988.

Haenchen, Ernst, John 1: A Commentary on the Gospel of John Chapters 1-6, tr. Robert W. Funk, Philadelphia: Fortress, 1984.

The Acts of the Apostles: A Commentary, tr. Bernard Noble, Gerald Shinn and R. McL. Wilson, Oxford: Blackwell, 1971.

The Harper Collins Study Bible: New Revised Standard Version, ed. Wayne A. Meeks et al., London: Harper Collins, 1989.

Harrison, Bernard, 'Deconstructing Derrida', Comparative Criticism 7 (1985), 324.

Hart, Kevin, The Trespass of the Sign: Deconstruction, Theology and Philosophy, Cambridge: Cambridge University Press, 1989.

Hartman, Geoffrey, Saving the Text: Literature/Derrida/Philosophy, Baltimore and London: Johns Hopkins University Press, 1981.

Hauerwas, Stanley, 'The Church as God's New Language', in Scriptural Authority and Narrative Interpretation, ed. Garrett Green, Philadelphia: Fortress, 1987, pp. 178-198.

Heath, Stephen, 'Literary Theory, etc.', Comparative Criticsm 9 (1987), 281326. 
Heidegger, Martin, Being and Time, tr. John Macquarrie and Edward Robinson, London: SCM Press, 1962.

Hesla, David H., 'Religion and Literature: The Second Stage', Journal of the American Academy of Religion 46 (1978), 181-192.

Hirsch, David H., 'Paul de Man and the Politics of Deconstruction', Sewanee Review 96 (1988), 330-338.

Hirsch, E.D., Jr., Validity in Interpretation, New Haven: Yale University Press, 1967.

Hodgson, Peter C., and Robert H. King, eds., Christian Theology: An Introduction to its Traditions and Tasks, London: SPCK, 1982.

Horney, Karen, New Ways in Psychoanalysis, London: Kegan Paul, 1939.

Hoy, David Couzens, The Critical Circle: Literature, History and Philosophical Hermeneutics, Berkeley and London: University of California Press, 1978.

'Heidegger and the Hermeneutic Turn', in The Cambridge Companion to Heidegger, ed. Charles B. Guignon, Cambridge: Cambridge University Press, 1993.

Husserl, Edmund, Logical Investigations Vol. I, tr. J. N. Findlay, London: Routledge and Kegan Paul, 1970.

Ideas: General Introduction to a Pure Phenomenology, tr. W.R. Boyce Gibson, London: Allen and Unwin, 1931.

Hyatt, J. Philip, Commentary on Exodus, London: Oliphants, 1971.

Irigaray, Luce, Speculum of the Other Woman, tr. Gillian C. Gill, New York: Cornell University Press, 1985. 
Jacobs, Janet Liebman, and Donald Capps, eds., Religion, Society and Psychoanalysis, Boulder, CO: Westview, 1997.

Jackson, B. Darrell, 'St. Augustine's Theory of Signs in De Doctrina Christiana', Révue des Études Augustiniennes 15 (1969), 9-49.

Jakobson, Roman, and Morris Halle, Fundamentals of Language, The Hague and New York: Mouton, 1980.

Jameson, Fredric, The Political Unconscions: Narrative as a Socially Symbolic Act, London: Methuen, 1981.

'Interview: Fredric Jameson', Diacritics 12 (1982), 72-91.

Postmodernism, or, The Cultural Logic of Late Capitalism, London and New York: Verso, 1991.

Japhet, Sara, Chronicles: A Commentary, London: SCM Press, 1993.

Jasper, David, The Study of Literature and Religion: An Introduction, London: Macmillan, 1989.

'The Study of Literature and Theology: Five Years On', Literature and Theology 6 (1992), 1-10.

Pope John Paul II, Redemptor Hominis (1979), tr. Vatican, <http://listerv. american.edu/catholic/church/papal/jp.ii/redeem.asc $>$.

Laborem Exercens, tr. Vatican, Boston: St. Paul, 1981.

Sollicitudo Rei Socialis, tr. Vatican, Boston: St. Paul, 1988.

Centesimus Annus, tr. Vatican, Boston: St. Paul, 1991.

Johnson, Pauline, Marxist Aesthetics: The Foundations within Everyday Life for an Emancipated Consciousness, London, Boston, Melbourne and Henley: Routledge and Kegan Paul, 1984.

Jones, David, Epoch and Artist, London: Faber and Faber, 1959. 
Jones, Ernest, Papers on Psychoanalysis, $4^{\text {th }}$ ed., London: Ballière, Tindall and Cox, 1938.

Sigmund Freud: Life and Work, 3 vols., London: Hogarth, 1953-1957.

Jordan, Mark D., 'Words and Word: Incarnation and Signification in Augustine's De Doctrina Christiana', Augustinian Studies 11 (1980), $177-196$

Jung, Carl Gustav, Psychology and Religion, New Haven: Yale University Press, 1938.

Complete Works Vol. 11: Psychology and Religion, tr. R.F.C. Hull, London: Routledge and Kegan Paul, 1958.

Kamuf, Peggy, ed., Between the Blinds: A Derrida Reader, New York: Harvester Wheatsheaf, 1991.

Kavanagh, James H., 'Marxism's Althusser: Toward a Politics of Literary Theory', Diacritics 12 (1982), 25-45.

Kavanagh, James H., and Thomas E. Lewis, 'Interview: Etienne Balibar and Pierre Macherey', Diacritics 12 (1982), 46-51.

'Interview: Terry Eagleton', Diacritics 12 (1982), 53-64.

Kearney, Richard, Dialogues with Contemporary Thinkers: The Phenomenological Heritage, Manchester: Manchester University Press, 1984.

Keeling, Michael, The Mandate of Heaven: The Divine Command and the Natural Order, Edinburgh: T. \& T. Clark, 1995.

Kelly, J.N.D., Early Christian Doctrines, $5^{\text {th }}$ ed., London: A. \& C. Black, 1977. Kenny, Anthony, Aquinas, London: Fontana, 1980. 
Kermode, Frank, ed., Selected Prose of T.S. Eliot, New York: Harcourt Brace Janovich, 1975.

Kimball, Roger, 'The Contradictions of Terry Eagleton', The New Criterion 9 (1990), 17-23.

'Fredric Jameson's Laments', The New Criterion 10 (1991), 9-17.

Kirschner, Suzanne R., The Religious and Romantic Origins of Psychoanalysis: Individuation and Integration in Post-Freudian Theory, Cambridge: Cambridge University Press, 1996.

Kneale, William, and Martha Kneale, The Development of Logic, Oxford: Clarendon Press, 1962.

Knight, George A.F., Theology as Narration: A Commentary on the Book of Exodus, Edinburgh: Handsel, 1976.

Kristeva, Julia, La Révolution du Langage Poétique, Paris: Éditions Seuil, 1974.

Desire in Language: A Semiotic Approach to Literature and Art, ed. Leon Roudiez, Oxford: Blackwell, 1980.

Powers of Horror: An Essay on Abjection, tr. Leon S. Roudiez, New York: Columbia University Press, 1980.

Tales of Love, tr. Leon S. Roudiez, New York: Columbia University Press, 1985.

Revolution in Poetic Language, tr. Margaret Waller, New York: Columbia University Press, 1984

In the Beginning Was Love: Psychoanalysis and Faith, tr. Arthur Goldhammer, New York: Columbia University Press, 1987.

Kroeber, A.L., Anthropology, London: Harrap, 1923. 
The Nature of Culture, Chicago and London: University of Chicago Press, 1952.

Küng, Hans, On Being a Christian, tr. Edward Quinn, London: Collins, 1978.

Freud and the Problem of God, New Haven: Yale University Press, 1979.

Does God Exist? An Answer for Today, tr. Edward Quinn, London: Collins, 1980

Lacan, Jacques, 'Desire and the Interpretation of Desire in Hamlet', tr. James Hulbert, Yale French Studies 55-56 (1977), 11 -52.

Écrits: A Selection, tr. Alan Sheridan, London: Routledge, 1977.

The Four Fundamental Concepts of Psycho-Analysis, tr. Alan Sheridan, London: Penguin, 1977.

Leavey, John P., Jr., 'Four Protocols: Derrida, His Deconstruction', Semeia 23 (1982), 43-57.

Lechte, John, Julia Kristeva, London and New York: Routledge, 1990.

van der Leeuw, Gerardus, Sacred and Profane Beauty: The Holy in Art, tr. David

E. Green, London: Weidenfeld and Nicolson, 1963.

Leitch, Vincent B., 'Postmodern Culture: The Ambivalence of Fredric Jameson', College Literature 19 (1992), 111-122.

Lemaire, Anika, Jacques Lacan, tr. David Macey, London and New York: Routledge, 1977.

Lenin, V.I., 'Letters to Maxim Gorky', Selected Works Vol. XI, London: Lawrence and Wishart, 1939, pp. 672-680.

'Socialism and Religion', Collected Works, London: Lawrence and Wishart; Moscow: Foreign Languages Publishing House, 1963 Vol. 10, pp. 83-87. 
'Leo Tolstoy as the Mirror of the Russian Revolution', Collected Works Vol. 15, pp. 202-209.

'The Attitude of the Worker's Party Towards Religion', Collected Works Vol. 15, pp. 402-413.

Lentricchia, Frank, After the New Criticism, London: Athlone, 1980.

Criticism and Social Change, Chicago and London: University of Chicago Press, 1983.

Pope Leo XIII, Aeterni Patris: On the Restoration of Christian Philosophy (1879), tr. Vatican, <http://listserv.american.edu/catholic/church/papal/ leo.xiii/113cphi.txt>.

Rermm Novarum, tr. N.C.W.C., Boston: St. Paul, 1942.

Lévi-Strauss, Claude, Structural Anthropology, tr. Claire Jacobson and Brooke Grundfest Schoepf, London: Penguin, 1963.

The Elementary Structures of Kinship, tr. James Harle Bell, John Richard von Sturmer and Rodney Needham, Boston: Beacon Press, 1969.

Lewis, Philip E., 'Revolutionary Semiotics', Diacritics 4 (1974), 28-32.

Lindbeck, George, The Nature of Doctrine: Religion and Theology in a Postliberal Age, Philadelphia: The Westminster Press, 1984.

Lloyd, David, 'In the Defiles of Analogy: The Ideology of the Aesthetic, by Terry Eagleton', Art History 14 (1991), 620-624.

Louth, Andrew, 'Augustine on Language', Literature and Theology 3 (1989), $151-158$

Lowe, Walter, Evil and the Unconscious, Chico, CA: Scholars Press, 1983.

Lukács, Georg, Writer and Critic and Other Essays, tr. Arthur Kahn, London: Merlin Press, 1978. 
Macherey, Pierre, A Theory of Literary Production, tr. Geoffrey Wall, London and New York: Routledge, 1978.

Machin, Richard, and Christopher Norris, eds., Post-Structuralist Readings of English Poetry, Cambridge: Cambridge University Press, 1987.

MacIntyre, Alisdair, Marxism and Christianity, London: Duckworth, 1968.

After Virtue: A Study in Moral Theory, Notre Dame, IN: University of Notre Dame Press, 1981.

Macquarrie, John, God-Talk: An Examination of the Language and Logic of Theology, London: SCM press, 1967.

Principles of Christian Theology, rev. ed., London: SCM Press, 1977.

de Man, Paul, Allegories of Reading: Figural Language in Rousseau, Nietzsche, Rilke and Proust, New Haven and London: Yale University Press, 1979.

Blindness and Insight: Essays in the Rhetoric of Contemporary Criticism, $2^{\text {nd }}$ ed., London: Routledge, 1983.

'The Resistance to Theory', Yale French Studies 63 (1982), 3-20.

The Rhetoric of Romanticism, New York: Columbia University Press, 1984.

Marcotte, Paul J., 'Maritain's Concepts of 'The Creative Intuition' and 'The Spiritual Unconscious of the Soul': Their Importance to, and their Neglect by, Professors and Students of English Studies', Journal of Canadian Poetry 3 (1981), 31-47.

Marion, Jean-Luc, God Without Being: Hors-Texte, tr. Thomas A. Carlson, Chicago and London: University of Chicago Press, 1991.

'Metaphysics and Phenomenology: A Relief for Theology', tr. Thomas A. Carlson, Critical Inquiry 20 (1994), 572-591. 
Maritain, Jacques, Art and Scholasticism with Other Essays, tr. J.F. Scanlan, London: Sheed and Ward, 1934.

Creative Intuition in Art and Poetry, London: The Harvill Press, 1953.

'Language and the Theory of the Sign', in Frontiers in Semiotics, ed. John Deely, Brooke Williams and Felicia E. Knose, Bloomington: Indiana University Press, 1986.

Markus, R.A., 'St. Augustine on Signs', Phronesis 2 (1957), 60-83.

Marrou, Henri-Irénée, Saint Augustin et la Fin de la Culture Antique, Paris: Boccard, 1949

Marx, Karl, Selected Writings, ed. David McLellan, New York: Oxford University Press, 1977.

Marx, Karl, and Friedrich Engels, On Literature and Art, ed. Stefan Baxandall and Lee Morawski, St. Louis: International General, 1973.

On Religion, Moscow: Progress Publishers, 1975.

Basic Writings on Politics and Philosophy, ed. Lewis S. Feuer, New York: Doubleday, 1989.

Collected Works Vol. 35: Capital Vol. I, London: Lawrence and Wishart, 1996.

Maurer, Armand, About Beauty: A Thomistic Interpretation, Houston: Centre for Thomistic Studies, 1983.

McGovern, Arthur F., Marxism: An American Christian Perspective, Maryknoll, NY: Orbis, 1980.

McInerny, Ralph. M., The Logic of Analogy: An Interpretation of St. Thomas, The Hague: Martinus Nijhoff, 1961. 
Being and Predication: Thomistic Interpretations, Washington, DC: Catholic University of America Press, 1986.

Art and Prudence: Studies in the Thought of Jacques Maritain, Notre Dame, IN: University of Notre Dame Press, 1988.

Aquinas and Analogy, Washington DC: Catholic University of America Press, 1996.

McLellan, David, Karl Marx: His Life and Thought, London: Macmillan, 1973. Marxism After Marx: An Introduction, London: Macmillan, 1979. Marx, 2nd ed., London: Fontana, 1986.

Mendelson, Jack, 'The Habermas-Gadamer Debate', New German Critique 18 (1979), 44-73.

Meng, Heinrich, and Ernst L. Freud, eds., Psychoanalysis and Faith: the Letters of Sigmund Freud and Oskar Pfister, London: The Hogarth Press, 1963.

Merton, Thomas, Seeds of Contemplation, Wheathampstead: Anthony Clarke, 1961

Michelfelder, Diane P., and Richard E. Palmer, eds., Dialogue and Deconstruction: The Gadamer-Derrida Encounter, New York: State University of New York Press, 1989.

Midrash Rabbah: Exodus, tr. S.M. Lehrman, London: Soncino Press, 1939.

Milbank, John, 'Theology Without Substance', Literature and Theology 2 (1988), 1-17, 131-152.

Millett, Kate, Sexual Politics, London: Virago, 1970.

Mills, Kevin, Justifying Language: Paul and Contemporary Literary Theory, London: Macmillan, 1995. 
Miranda, Jose Porfirio, Marx and the Bible: A Critique of the Philosophy of Oppression, tr. John Eagleson, Maryknoll, NY: Orbis, 1974.

Mitchell, Juliet, Psychoanalysis and Feminism, London: Allen Lane, 1974.

Mitchell, Juliet, and Jacqueline Rose, eds., Feminine Sexuality: Jacques Lacan and the École Freudienne, London: Macmillan 1982.

Moi, Toril, ed., The Kristeva Reader, Oxford: Blackwell, 1986.

Mueller-Vollmer, Kurt, ed. The Hermeneutics Reader: Texts of the German Tradition from the Enlighterment to the Present, Oxford: Blackwell, 1985

Mulhern, Francis, ed., Contemporary Marxist Literary Criticsm, London and New York: Longman, 1992.

Muller, John P. and William J. Richardson, eds., The Purloined Poe: Lacan, Derrida and Psychoanalytic Reading, Baltimore and London: Johns Hopkins University Press, 1988.

Newton, K.M., 'Hermeneutics and Modern Literary Criticism', British Journal of Aesthetics 29 (1981), 116-127.

Norris, Christopher, Derrida, London: Fontana, 1987.

'Limited Think: How Not to Read Derrida', Diacritics 20 (1990), 17-36.

Deconstruction: Theory and Practice, rev. ed., London and New York: Routledge, 1991

Noth, Martin, Exodus: A Commentary, tr. J.S. Bowden, London: SCM, 1962.

Ong, Walter J., Orality and Literacy: The Technologizing of the Word, London and New York: Methuen, 1982.

O'Connell, Robert, Art and the Christian Intelligence in St. Augustine, Oxford: Blackwell, 1978. 
O'Reilly, Leo, Word and Sign in the Acts of the Apostles: A Study in Lucan Theology, Rome: Editrice Pontifica Università Gregoriana, 1987.

Owens, Joseph, 'Aristotle and Aquinas', in The Cambridge Companion to Aquinas, ed. Norman Kretzmann and Eleonore Stump, Cambridge: Cambridge University Press, 1993.

Oxenhandler, Neal, 'Maritain and Recent Critical Thought', Renascence: Essays on Value in Literature 34 (1982), 260-270.

Pannenberg, Wolfhart, Basic Questions in Theology Vol. I, tr. George H. Kehm, London: SCM Press, 1970.

Pope Paul VI, 'The Friendship of Artists and the Church', The Pope Speaks 9 (1964), 390-395.

Pelikan, Jaroslav, The Christian Tradition: A History of the Development of Doctrine Vol. l: The Emergence of the Catholic Tradition (100-600), Chicago and London: University of Chicago Press, 1971.

Philo of Alexandria, De Vita Mosis, with a French translation by Roger Arnaldez, Paris: Éditions du Cerf, 1967.

De Decalogo, with a French translation by Valentin Nikiprowetzky, Paris: Éditions du Cerf, 1965.

Pieper, Josef, Guide to Thomas Aquinas, tr. Richard and Clara Winston, Notre Dame, IN: University of Notre Dame Press, 1962.

Pope Pius XI, ‘Studiorum Ducem', Acta Apostolicae Sedis 15 (1923), 312-316. Poland, Lynn M., 'Augustine, Allegory and Conversion', Literature and Theology 2 (1988), 37-48.

Popper, Karl R., Conjectures and Refutations: The Growth of Scientific Knowledge, London: Routledge and Kegan Paul, 1963. 
Prickett, Stephen, Words and the Word: Language, Poetics and Biblical Interpretation Cambridge: Cambridge University Press, 1986.

von Rad, Gerhard, Old Testament Theology, 2 vols., tr. D.M.G. Stalker, London: SCM Press, 1962-1965.

Genesis: A Commentary, $2^{\text {nd }}$ ed, tr. John H. Marks, London: SCM, 1963.

Radcliffe-Brown, A.R., Structure and Function in Primitive Society: Essays and Addresses, New York and London: the Free Press, 1952.

Rahner, Karl, Theological Investigations Vol. I: God, Christ, Mary and Grace, tr. Cornelius Ernst, London: Darton, Longman and Todd, 1961.

'Scripture and Tradition', in Theological Investigations Vol. VI: Concerning Vatican Council II, tr. Karl-H. and Boniface Kruger, London: Darton, Longman and Todd, 1969.

Ratzinger, Joseph and Alberto Bovone, Sacred Congregation for the Doctrine of the Faith: Instruction on Certain Aspects of the 'Theology of Liberation' (1984), tr. Vatican, <http://listserv.american.edu/catholic/church/vatican/ libtheo.asc>

Ricoeur, Paul, Freud and Philosophy: An Essay in Interpretation, New Haven and London: Yale University Press, 1970.

Hermeneutics and the Human Sciences, tr. John B. Thompson, Cambridge and Paris: Cambridge University Press and Éditions de la Maison des Sciences de l'Homme, 1981.

Richard of Saint-Victor, Selected Writings on Contemplation, tr. Clare Kirchberger, London: Faber and Faber, 1957.

Rorty, Richard, Consequences of Pragmatism: Essays 1972-1980, Brighton: Harvester Press, 1982. 
'Deconstruction and Circumvention', Critical Inquiry 11 (1984), 1-23.

Ross, James F., 'Analogy as a Rule of Meaning for Religious Language', in Aquinas: A Collection of Critical Essays, ed. Anthony Kenny, London: Macmillan, 1969, pp. 93-138.

Ryden, Edmund, 'Aquinas on the Metaphorical Expression of Theological Truth', Heythrop Journal 27 (1986), 409-419.

Ryken, Leland, 'The Contours of Christian Criticism in 1987 ', Christianity and Literature 37 (1987), 23-37.

Ryken, Leland, ed., The Christian Imagination: Essays on Literature and the Arts, Grand Rapids, Michigan: Baker, 1981.

D'Sa, Francis X., 'The Language of God and the God of Language: The Relation between God, Human Beings and Language in St. John', in God In Language, ed. Robert P. Scharlemann and Gilbert E.M. Ogutu, New York: Paragon, 1987.

Scarfe, Alan, and Patrick Sookhdeo, Christianity and Marxism, Exeter: Paternoster, 1982.

Schildgen, Brenda Deen, 'Augustine's Answer to Jacques Derrida in the De Doctrina Christiana', New Literary History 25 (1994), 383-397.

Scleshinger, George N., Metaphysics: Methods and Problems, Oxford: Blackwell, 1983.

Schnackenburg, Rudolf, The Gospel according to St. John Vol. 1, tr. Kevin Smyth, London: Burns and Oates, 1980.

Schoonenberg, Piet, Man and Sin: A Theological View, tr. Joseph Donceel, London: Sheed and Ward, 1965 
Scott, Nathan A., Jr., 'The Relation of Theology to Literary Criticism', Journal of Religion XXXIII (1953), 266-277.

'Prolegomenon to a Christian Poetic', Journal of Religion XXXV (1955), 191-206.

'Maritain in his Role as Aesthetician', Review of Metaphysics 8 (1955), 480492.

Negative Capability: Studies in the New Literature and the Religions Situation, New Haven: Yale University Press, 1969.

The Wild Prayer of Longing: Poetry and the Sacred, New Haven and London: Yale University Press, 1971.

The Poetics of Belief, Chapel Hill and London, University of North Carolina Press, 1985.

Scott, Nathan A., Jr., ed., The New Orpheus: Essays Towards A Christian Poetic, New York: Sheed and Ward, 1964.

Actversity and Grace: Studies in Recent American Literature, Chicago: University of Chicago Press, 1968.

Sellers, Susan, Language and Sexual Difference: Feminist Writing in France, London: Macmillan, 1991.

Sextus Empiricus, Outlines of Pyrrhonism, with an English translation by R.G. Bury, London: Heinemann, 1933.

Against the Logicians, with an English translation by R.G. Bury, London: Heinemann, 1935.

Sprinker, Michael, 'The Legacies of Althusser', Yale French Studies 88 (1995), 201-225. 
Steiner, George, Real Presences: Is There Anything In What We Say?, London and Boston: Faber and Faber, 1989.

Heidegger, 2nd ed., London: Fontana, 1992.

Stepanova, E.A., 'Exhausted Marxism: An Examination of Marxist Doctrine in the Traditions of Russian Religious Philosophy', Soviet Studies in Philosophy 29 (1991), 6-34.

Stock, Brian, Augustine the Reader: Meditation, Self-Knowledge and the Ethics of Interpretation, Cambridge, MA: Harvard University Press, 1996.

Targum Neofiti 1: Genesis, tr. Martin McNamara, Edinburgh: T. \& T. Clark, 1992.

Tartarkiewicz, Wladyslaw, History of Aesthetics Vol. II: Medieval Aesthetics, tr. R.M. Montgomery, The Hague and Paris: Mouton, 1970.

Thiselton, Anthony C., The Two Horizons: New Testament Hermeneutics and Philosophical Description with Special Reference to Heidegger, Bultmann, Gadamer and Wittgenstein, Grand Rapids, MI: Eerdmans, 1980.

New Horizons in Hermeneutics, London: Harper Collins, 1992.

Tillich, Paul, The Protestant Era, tr. James Luther Adams, London: Nisbet, 1951.

Tobin, Thomas H., 'The Prologue of John and Hellenistic Jewish Speculation', Catholic Biblical Quarterly 52 (1990), 252-269.

Turner, Denys, Marxism and Christianity, Oxford: Blackwell, 1983

Vance, Eugene, Mervelous Signals: Poetics and Sign Theory in the Middle Ages, Lincoln, NE: University of Nebraska Press, 1986. 
Vitz, Paul C., and John Gartner, 'Christianity and Psychoanalysis Part 1: Jesus as the Anti-Oedipus', Journal of Psychology and Theology 12 (1984), 4-14.

'Christianity and Psychoanalysis, Part 2: Jesus the Transformer of the SuperEgo', Journal of Psychology and Theology 12 (1984), 82-90.

Walhout, Clarence P., 'Literary Criticism in the Christian Community', Christian Scholar's Review 8 (1979), 298-304.

'A New Direction for Christian Literary Theory', Christian Scholar 's Review $10(1981), 155-157$

‘Can Derrida Be Christianized?', Christianity and Literature 34 (1984), 1522.

'A Response to Leland Ryken's Proposals For Christian Literary Critics', Christianity and Literature 37 (1987), 39-43.

'The Problem of Moral Criticism in Christian Literary Theory', Christian Scholar's Review 24 (1994), 26-44.

Walhout, Clarence P., and Leland Ryken, eds., Contemporary Literary Theory: A Christian Appraisal, Grand Rapids, Michigan: Eerdmans, 1991.

Walhout, Mark, 'Aesthetic Experience and Social Justice: Historical Reflections on Christian Criticism', Christian Scholar 's Review 16 (1987), 249-264.

Walsh, Michael, and Brian Davies, eds. Proclaiming Justice and Peace: Documents from John XXIII to John Paul II, London: Collins, 1984.

Walsh, R. T., Neoplatonism, London: Duckworth, 1972.

Ward, Graham, 'Heidegger in Steiner', in Reading George Steiner, ed. Nathan A. Scott, Jr. and Ronald A. Sharp, Baltimore and London: Johns Hopkins University Press, 1994, pp. 180-204. 
Barth, Derrida and the Language of Theology, Cambridge: Cambridge University Press, 1995.

Theology and Contemporary Literary Theory, London: Macmillan, 1996.

Ward, Patricia A., 'Woridly Readers and Writerly Texts', Christian Scholar's Review 17 (1988), 433- 435.

'Ethics and Recent Literary Theory: The Reader as Moral Agent', Religion and Literature 22 (1990), 21-31.

Warfield, Benjamin Breckenridge, Studies in Tertullian and Augustime, New York: Oxford University Press, 1930.

Webster, Richard, Why Freud Was Wrong: Sin, Science and Psychoanalysis, London: Harper Collins, 1995.

Weinsheimer, Joel C., Gadamer's Hermeneutics: A Reading of Truth and Method, New Haven and London: Yale University Press, 1985.

Westermann, Claus, Genesis I-11: A Commentary, $2^{\text {nd }}$ ed, tr. John J. Scullion, London: SPCK, 1984.

Whitford, Margaret, ed., The Irigaray Reader, Oxford: Blackwell, 1991.

Williams, Rowan, 'Language, Reality and Desire in Augustine De Doctrina', Literature and Theology 3 (1989), 138-150.

Wimsatt, William K., $\mathrm{J}_{\mathrm{r}}$, Hateful Contraries: Studies in Literature and Criticism, Lexington: University of Kentucky Press, 1965.

Wimsatt, William K., Jr., and Monroe C. Beardsley, The Verbal Icon: Studies in the Meaning of Poetry, Lexington: University of Kentucky Press, 1954.

Wimsatt, Witliam K., Jr., and Cleanth Brooks, Literary Criticisms: A Short History, London: Roukledge and Kegan Paul, 1957.

Wolheim, Richard, Freud, London: Fontana, 1971. 
Wood, David, ed., Derrida: A Critical Reader, Oxford: Blackwell, 1990.

Wright, Elizabeth, Psychoanalytic Criticism, London: Routledge, 1984.

Wright, T.R., Theology and Literature, Oxford: Blackwell, 1988

Wyschogrod, Edith, David Crownfield and Carl A. Raschke, eds., Lacan and Theological Discourse, Albany, NY: State University of New York Press, 1989.

Yu, Anthony C., 'Nathan A. Scott, Jr.: An Appreciation', in Morphologies of Fath: Essays in Religion and Culture in Honour of Nathan A. Scott, Jr., ed. Mary Gerhart and Anthony C. Yu, Atlanta: Scholars Press, 1990, pp. ix-xxix.

The Zondervan Parallel New Testament in Greek and English, Grand Rapids, MI: Zondervan, 1975. 